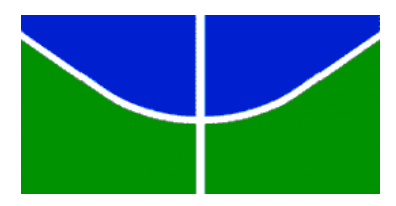

Universidade de Brasília - UnB

Instituto de Letras - IL

Departamento de Linguística, Português e Línguas Clássicas - LIP

Programa de Pós-Graduação em Linguística - PPGL

\title{
A REPRESENTAÇÃO DO POVO BRASILEIRO EM DISCURSOS PARLAMENTARES
}

Angela Silva da Veiga

Brasília/DF

2015 


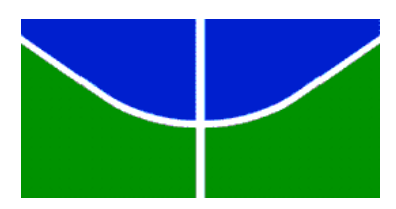

\title{
Universidade de Brasília - UnB \\ Instituto de Letras - IL
}

Departamento de Linguística, Português e Línguas Clássicas - LIP

Programa de Pós-Graduação em Linguística - PPGL

\author{
Angela Silva da Veiga
}

\section{A REPRESENTAÇÃO DO POVO BRASILEIRO EM DISCURSOS PARLAMENTARES}

Dissertação apresentada ao Programa de PósGraduação em Linguística do Departamento de Linguística, Língua Portuguesa e Línguas Clássicas do Instituto de Letras da Universidade de Brasília, como parte dos requisitos para a obtenção do grau de Mestre em Linguística. Área de concentração: Linguagem $e$ Sociedade.

Orientadora: Prof ${ }^{\mathrm{a}}$ Dra. Edna Cristina Muniz da Silva

\section{Brasília/DF}

2015 
Ficha catalográfica elaborada automaticamente.

com os dados fornecidos pelo(a) autor(a)

Veiga, Angela Silva da

Â Repreaentaçäo do Povo em Discurmoa Parlamentaren / Angela Silva da Veiga; orientador Bdna Criatina Muniz da Silva. -- Brasilia, 2015.

224 p.

Diemertaç̄̃o (Meatrado - Meatrado em Linguintica) Univeraidade de Branilia, 2015.

1. Reprementaç̄o. 2. Dimcurmo Politico. 3. Anslime do Discurao Critica. 4. Linguintica Siatemico

Funcional. I. Silva, Bdna Criatina Muniz da, orient.

II. Titulo. 


\title{
A REPRESENTAÇÃO DO POVO BRASHLEIRO EM DISCURSOS PARLAMENTARES
}

\author{
ANGELA SILVA DA VEIGA
}

Dissertação apresentada ao Programa de Pós-Graduação em Linguística do Departamento de Linguística, Língua Portuguesa e Línguas Clássicas do Instituto de Letras da Universidade de Brasília, como parte dos requisitos para a obtenção do grau de Mestre em Linguística, área de concentração: Linguagem e Sociedade, defendia em 7 de dezembro de 2015, Banca Examinadora constituída pelas professoras:

\section{Shusil var}

Prof" Dra. Edna Cristina Muniz da Silva

Universidade de Brasília (UnB) - Presidente

\section{Anos}

Prof" Dra. Juliana de Freitas Dias

Universidade de Brasília (UnB) - Membro efetivo interno<smiles>[Mg][Mg][Mg][Ca]</smiles>

Prof Dra. Kelly Cristina de Almeida Moreira

Secretaria de Estado de Educação (SEE) - Membro efetivo externo

Prof" Dra. Francisca Cordélia Oliveira da Silva

Universidade de Brasília (UnB) - Membro suplente interno 
A Deus e à minha família. 


\section{AGRADECIMENTOS}

Agradeço a Deus pela vida, saúde e pela capacitação para conseguir concluir este trabalho.

Agradeço aos meus pais, Jurandy e Helena, pelo amor, dedicação e apoio que me fizeram chegar até aqui. Aos meus irmãos, Risomar e Luciano, pelo aprendizado de vida diário.

Ao meu namorado, Rodrigo, pelo incentivo, conselhos e companheirismo valiosos.

Aos meus amigos da UnB, Alley Cândido, Ana Claudia, Miguel Angelo e Hudson Nogueira, por compartilharem seus conhecimentos e por trilharem essa jornada acadêmica comigo.

À minha orientadora, Professora Doutora Edna Cristina Muniz da Silva, pela compreensão, amizade e por dividir seu vasto conhecimento comigo.

À Professora Doutora Juliana Dias, Professora Doutora Kelly Cristina de Almeida Moreira e Professora Doutora Francisca Cordélia pela disponibilidade em participar da banca e colaborar com este trabalho.

Ao Departamento de Taquigrafia da Câmara dos Deputados, especialmente aos colegas da Seção de Indexação de discursos, pelo trabalho ali realizado e por terem me dado a oportunidade de conhecer e selecionar os dados utilizados nesta pesquisa. 
"A língua tem poder sobre a vida e sobre a morte; os que a usam habilmente serão recompensados."

Provérbios 18:21

A única coisa que mete medo em político éo povo na rua.

Ulysses Guimarães 


\section{RESUMO}

A presente dissertação tem por objetivo analisar linguisticamente e discursivamente a representação do povo em discursos parlamentares a respeito das grandes manifestações populares ocorridas no mês de junho de 2013 no Brasil. Tais protestos tiveram repercussão mundial tornando-se manchete em jornais de vários países. Trata-se de uma pesquisa documental com abordagem qualitativa. E, no sentido de compreender o fenômeno linguístico-discursivo estudado, apoio-me na Análise de Discurso Crítica de Fairclough (1999, 2001, 2003) que considera a linguagem como prática social e na Linguística Sistêmico-Funcional de Halliday (2014) que estuda a linguagem a partir da situação de uso. Com base nesse aporte teórico que, por sua natureza propicia o entendimento das ideologias, discursos de Deputados Federais serão analisados a respeito dos acontecimentos daqueles dias. Assim, as categorias gramaticais das Metafunções Ideacional e Interpessoal serão investigadas no sentido de compreender de que forma esses elementos podem revelar o posicionamento dos políticos. Analiso ainda, com base na Representação dos Atores Sociais de van Leeuwen (2008), a maneira como manifestantes e parlamentares aparecem ou são apagados dos discursos e o que isso pode significar. Os conceitos de confiança e risco apresentados por Giddens (1991) também podem ser úteis na busca da compreensão de tal fenômeno. Além disso, a contribuição de Bauman $(1999,2001)$ sobre identidade e mudanças ocorridas na humanidade a partir da modernidade me auxiliará no entendimento desses acontecimentos. O corpus desta pesquisa constitui-se de dezesseis discursos de líderes partidários, do líder do governo e do líder da minoria. Dessas falas foram extraídos excertos que tratam do povo e das manifestações. $\mathrm{O}$ estudo permitiu constatar a presença de vários modalizadores indicando obrigação, principalmente a necessidade de os governantes ouvirem a população. Há também muitas marcas de imprecisão e incerteza, que demonstraram pouca disposição dos políticos em se comprometerem com que estava sendo falado. Outro recurso linguístico aplicado foi o uso do verbo querer em locução verbal para tornar as assertivas menos firmes e o parlamentar menos compromissado com o que era dito. Constatou-se a predominância de processos mentais e relacionais, o que demonstra que em seus pronunciamentos, os oradores buscavam caracterizar e ao mesmo tempo refletir sobre os acontecimentos. Verifiquei que havia diferença quanto à representação de alguns atores sociais nos discursos, em algumas falas ocorriam com destaque, em outras nem eram mencionados, conforme o enfoque que o parlamentar escolhia dar. $\mathrm{O}$ resultado da descrição e da análise dos dados mostrou que os participantes relacionados ao governo ocorreram mais vezes em posição de agência, enquanto o povo apareceu como paciente e beneficiário de ações, numa situação secundária. A principal reação da população, segundo os discursos, é desejar alguma coisa, enquanto para os políticos é pensar e refletir sobre os acontecimentos. Há uma perplexidade dos parlamentares, de maneira geral, diante dos protestos, por isso eles conclamam seus pares a ouvirem a povo e refletir sobre seus anseios. Verificamos que algumas reivindicações foram atendidas, mas é necessário que os cidadãos continuem atentos e acompanhem os processos decisórios no Congresso Nacional.

Palavras-chave: Discurso Político. Representação. Povo. Manifestação. Linguística Sistêmico-Funcional. 


\begin{abstract}
The present dissertation aims to analyse linguistically and discursively the representation of people in parliamentary discourse about the great protests that took place in Brazil in June of 2013. Those protests have had worldwide repercussions. This is a documental research of qualitative nature. To understand the linguistic-discursive phenomenon the theoreticalanalytical framework used is the Critical Discourse Analysis proposed by Fairclough (1999, 2001, 2003) which considers the language as a social practice, the Systemic Functional Linguistics from Halliday (2014) which studies the language as it is used in real situations and the Theory of Representing Socia Actors from Theo van Leeuwen (2008). According to those theories, political discourses from Deputies will be analysed and, thus, reveal the politicians' position and which elements are included and which are excluded from the speeches and what that means. The concepts of trust and risk from Giddens (1991) will be useful and also the contribution from Bauman $(1999,2001)$ about identity and changes in modernity will help us realize those historical events. The data for this research was taken from sixteen discourses from political parties leaders from the Chamber of Deputies. The study revealed the presence of several modalizers indicating obligation, especially the need for the politicians to listen to the population. There are also many clues of vagueness and uncertainty, which demonstrated unwillingness of politicians to be committed to what was being said. Another linguistic feature applied was the use of the verb want in verbal expression to make the sentences less assertive and parliamentary less committed to their speeches. It was found the prevalence of mental and relational processes, which shows that in his speeches, the speakers sought to characterize and at the same time reflect on the events . I found that there was difference in the representation of some social actors in speeches. I got also, as a result, that the participants related to the government occurred more often in agency position, while the people appeared as a patient and beneficiary of some actions, in a secondary position. The main reaction of the population, according to the speeches, is to desire something while for politicians is to think and reflect on the events. There is perplexity of parliamentarians in general, because of the protests, so they call upon their peers to hear the people and reflect on their concerns. We found that some claims were met, but it is necessary that citizens remain vigilant and monitor the decision-making process in Congress.
\end{abstract}

Keywords: Political Discourse. Representation. People. Protest. Systemic Functional Linguistics. 


\section{LISTA DE ILUSTRAÇÕES}

Figura 1- As Metafunções . Adaptado de Halliday (2014)......................................................... 30

Figura 2 - Total de discursos por partido político sobre as manifestações em 18/06/2013 ............. 56

Figura 3 - Tela do AntConc (Lista de palavras). ................................................................... 58

Figura 4 - Tela do AntConc (Busca pela palavra "POVO”) ........................................................ 58

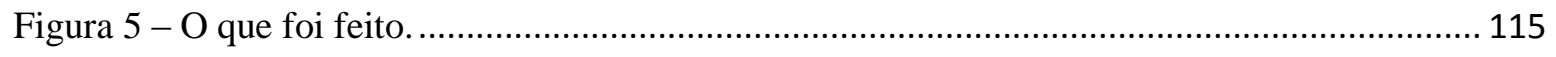

\section{LISTA DE QUADROS}

Quadro 1- Metafunções e variáveis de contexto ...................................................................... 27

Quadro 2- Sistema da Transitividade ................................................................................ 28

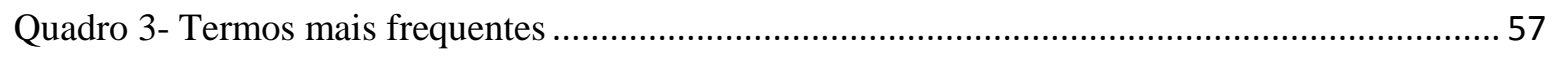

Quadro 4- Contexto situacional, semântica e léxico-gramática .................................................... 65

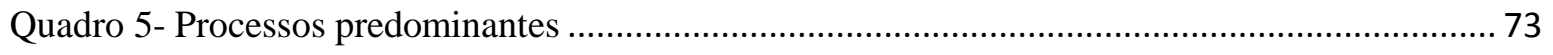

Quadro 6- Gradação dos processos mentais ............................................................................. 78

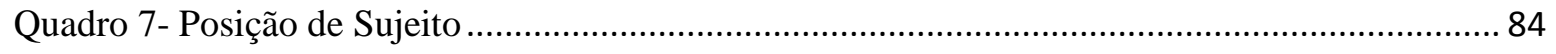

Quadro 8- Inclusão e Exclusão de Atores Sociais..................................................................... 121 


\section{LISTA DE SIGLAS E ABREVIATURAS}

\begin{tabular}{ll} 
ADC & Análise de Discurso Crítica \\
CD & Câmara dos Deputados \\
LSF & Linguística Sistêmico- Funcional \\
DEM & Democratas \\
PC DO B & Partido Comunista do Brasil \\
PHS & Partido Humanista da Solidariedade \\
PMDB & Partido do Movimento Democrático Brasileiro \\
PMN & Partido da Mobilização Nacional \\
PP & Partido Progressista \\
PPS & Partido Popular Socialista \\
PR & Partido da República \\
PSB & Partido Socialista Brasileiro \\
PSD & Partido Social Democrático \\
PSDB & Partido da Social Democracia Brasileira \\
PT & Partido dos Trabalhadores \\
PTB & Partido Trabalhista Brasileiro \\
PV & Partido Verde \\
\hline
\end{tabular}




\section{Sumário}

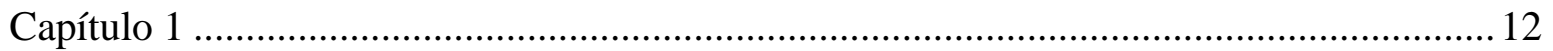

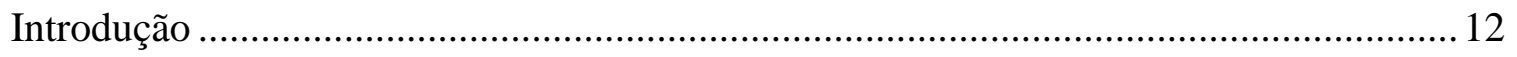

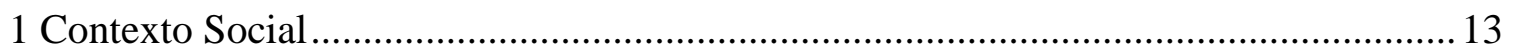

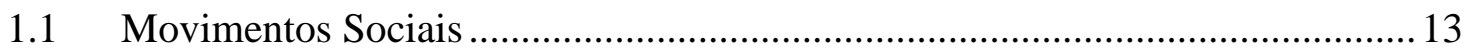

1.2 O Deputado Federal como Representante do Povo.............................................. 16

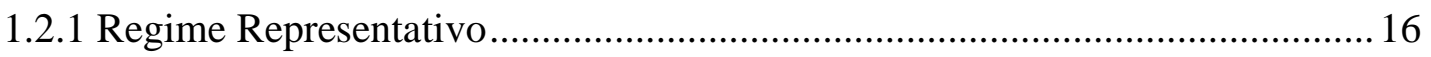

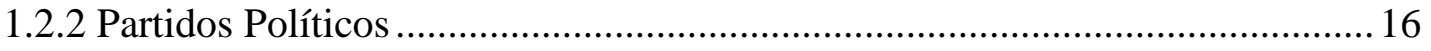

1.2.3 O Papel do Deputado Federal ............................................................................ 17

1.2.4 Das Sessões da Câmara dos Deputados ................................................................. 17

1.3 Discurso Político …………………..................................................................... 19

1.4 Modernidade, Confiança e Poder ………………………………………….......22

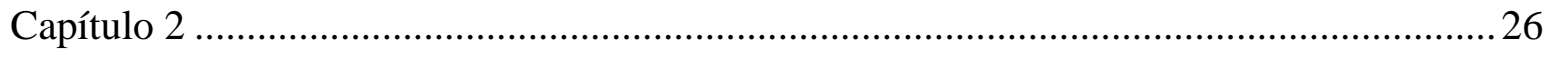

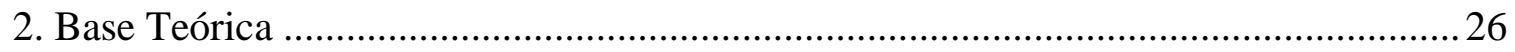

2.1 Linguística Sistêmico-Funcional.............................................................................226

2.1.1 Metafunção Ideacional ...............................................................................28

2.1.1.1 Processos Materiais.................................................................................... 30

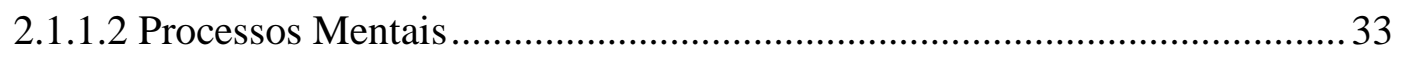

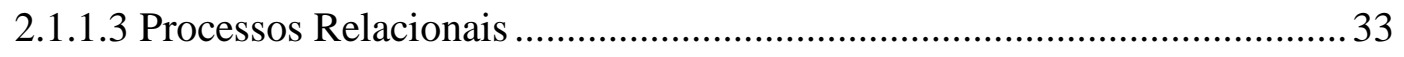

2.1.1.4 Processos Verbais ................................................................................. 35

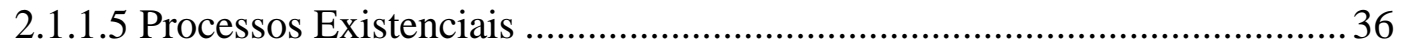

2.1.1.6 Processos Comportamentais ....................................................................... 37

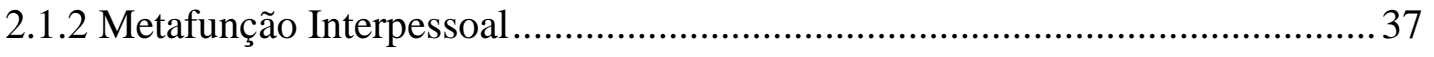

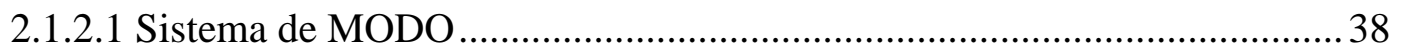




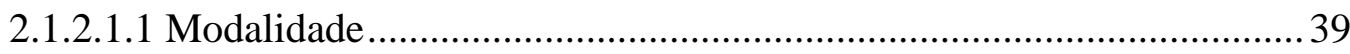

2.2 A Representação dos Atores Sociais ..................................................................... 41

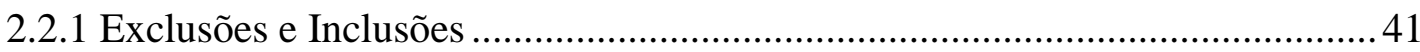

2.3 Representação (Fairclough 2003)........................................................................... 44

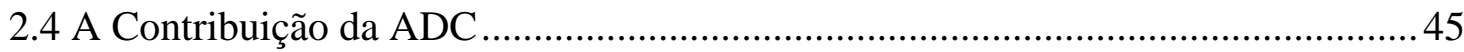

2.5 Abordagens teóricas - integração ……………………………………………….....4 48

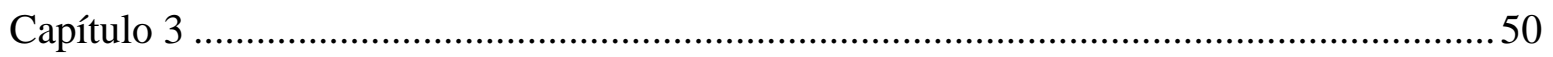

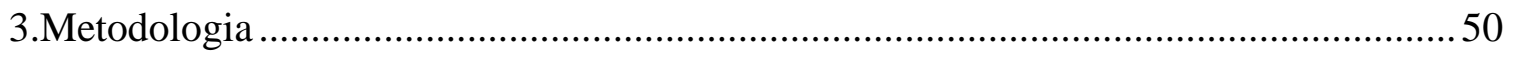

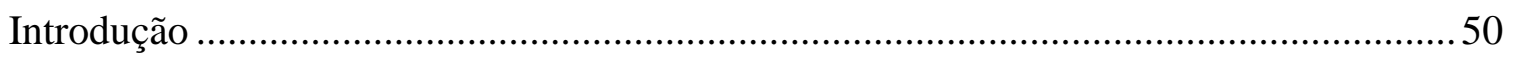

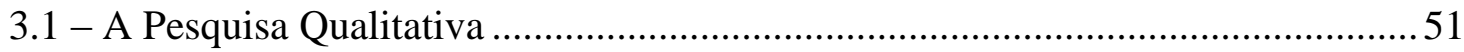

3.2 Pesquisa documental ......................................................................................52

3.3 Questões de Pesquisa ...........................................................................................54

3.4 Descrição do Corpus ..........................................................................................5

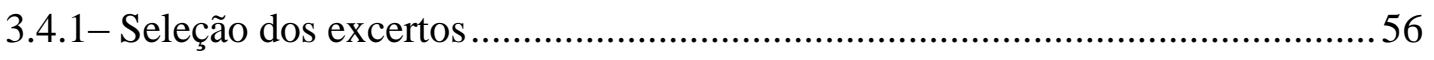

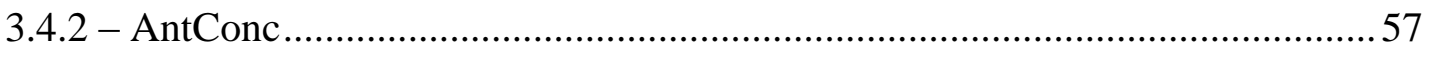

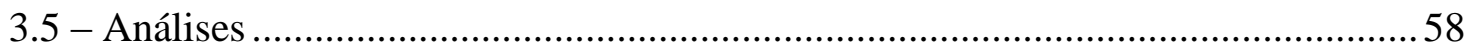

3.5.1- Compilação dos resultados ..........................................................................5

3.6 Arcabouço da ADC ……………………………................................................ 60

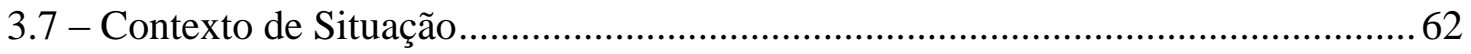

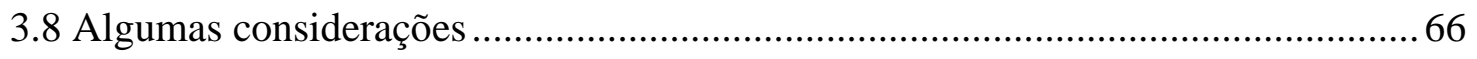

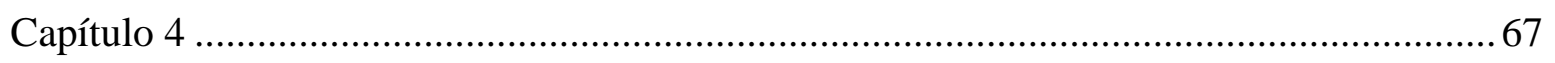

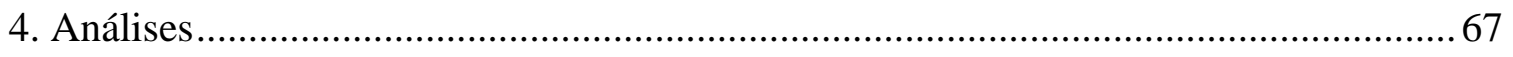

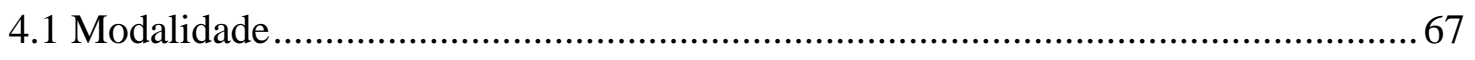

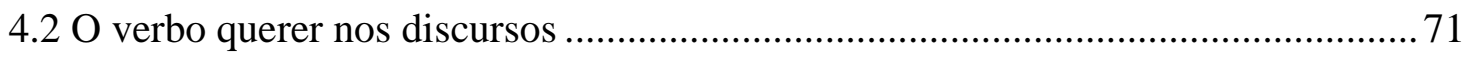

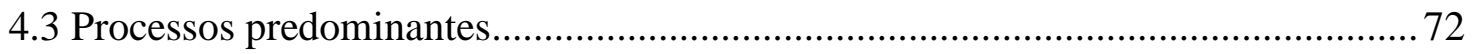


4.3.1 Gradação dos processos mentais .......................................................... 77

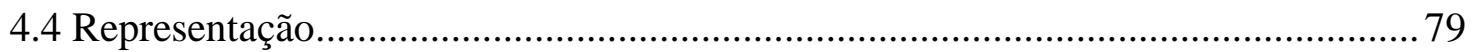

4.4.1 Representação segundo Van Leeuwen ..................................................... 83

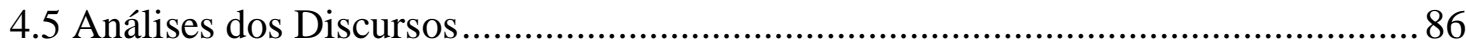

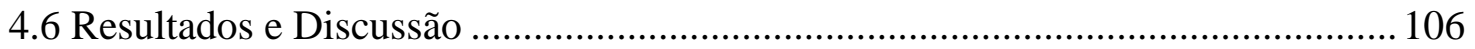

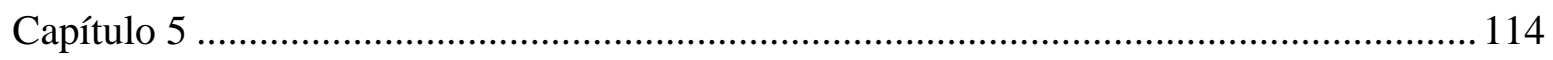

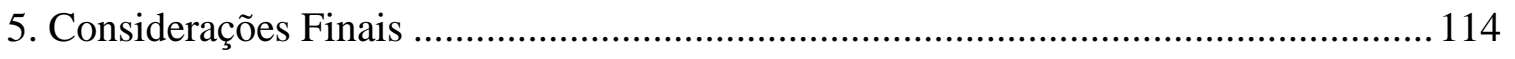

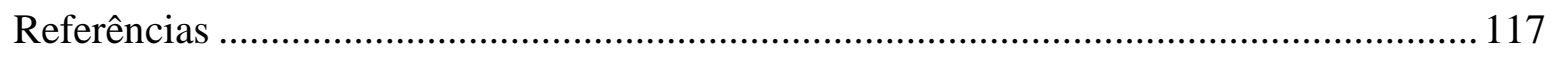

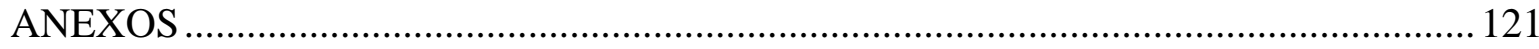




\section{Capítulo 1}

\section{Introdução}

Sou técnica legislativa na Câmara dos Deputados desde 2011. Estive lotada no Departamento de Taquigrafia por três e meio e trabalhava fazendo a indexação de discursos parlamentares para que eles fossem recuperados por pesquisadores. Por trabalhar lendo esses discursos todos os dias, percebi neles um campo fértil de pesquisa. Em 2013, ao cursar Linguística Sistêmico-Funcional, na UnB, como aluna especial, encontrei no meu material de trabalho uma fonte para a análise que eu precisava fazer para concluir a disciplina. Os discursos sobre as manifestações ocorridas naquele ano chamaram a minha atenção. Era um momento de tensão no parlamento brasileiro e um momento histórico em que a população se unia em protesto nas ruas. Os discursos analisados nesta dissertação foram proferidos um dia depois de uma grande manifestação em que houve uma tentativa de invasão do Congresso Nacional. Pensei, então, que analisar linguisticamente a fala dos congressistas seria uma forma de tentar compreender aquele momento de mudança social.

Além disso, sabendo que à Câmara dos Deputados cumpre o papel de representar o povo brasileiro, legislar sobre os assuntos de interesse nacional e fiscalizar a aplicação dos recursos públicos, percebi que essa função de representante do povo foi questionada no momento em que as pessoas foram para as ruas falar por si mesmas. Com base nessas ponderações, esse trabalho se justifica, pois busca desvelar como esses mandatários representam o povo e seus anseios no Congresso Nacional e como eles se mostram perante o povo por meio de seus discursos políticos.

Dessa maneira, o objetivo central deste estudo será analisar a representação do povo feita pelos parlamentares em seus discursos durante o período das manifestações de junho de 2013. Como objetivos específicos, buscarei:

1) Verificar com que termos a população foi representada, ocupando o lugar de qual participante no Sistema da Transitividade.

2) Observar o comprometimento do deputado com o que é falado, por meio do Sistema de Modo.

3) Investigar que atores sociais são excluídos e incluídos nos discursos. 


\section{Contexto Social}

O foco deste capítulo é apresentar uma contextualização dos assuntos abordados nesta pesquisa. Sendo assim, a primeira seção trata dos movimentos sociais, pois as manifestações que ocorreram em 2013 no Brasil refletem algo que vinha acontecendo também em outros países do mundo, onde pessoas foram às ruas protestar e reivindicar direitos. A segunda seção fala do Deputado Federal e de seu papel como representante do povo, tendo em vista que este trabalho se propõe a analisar discursos desses parlamentares e que grandes protestos foram feitos em frente à sede do Poder Legislativo Federal. Já a terceira seção aborda as características do discurso político, alvo de minha investigação nesta pesquisa. Por último, apresento uma seção a respeito de confiança e poder na modernidade.

\subsection{Movimentos Sociais}

Castells (2013) analisa a maneira como se formaram os recentes movimentos sociais disseminados pelas redes sociais na internet e a motivação para essas mobilizações de indignação acontecerem. Ele avalia que a internet é um espaço de comunicação que fugiu ao controle dos governos e das empresas. Tais instituições possuem, costumeiramente, o monopólio dos meios de comunicação como base de poder (p.11).

O pensador espanhol, ao analisar os diversos movimentos de protesto que ocorreram no mundo desde a Primavera Árabe, fala que a arrogância e o cinismo de quem está no poder causaram humilhação e raiva na população (p. 12) que se comunicou pelas redes sociais e, em seguida, passou a ocupar espaços públicos em protesto.

Ele lembra que as instituições são construídas de acordo com os valores e interesses daqueles que estão no poder. Para manter o status quo, os governantes buscam a construção de significado na mente das pessoas, essa seria uma forma decisiva de manutenção do poder. E nada melhor para influenciar o pensamento das pessoas do que as redes de comunicação. No entanto, o surgimento da internet e meios de comunicação sem fio criou o que o autor chama de autocomunicação (p.15), dando autonomia ao ator social 
(individual ou coletivo). E essa autonomia é fundamental para os movimentos sociais.

O autor analisa também o significado e a importância da ocupação dos locais públicos (p.19). Segundo ele, tal ocupação cria comunidade devido à proximidade, e ao mesmo tempo cria um espaço de deliberação. No caso do Brasil, as manifestações na porta do Congresso, em 2013, contestavam a representação exercida pelos políticos. Ele fala também do que leva pessoas a se arriscarem, infringindo leis, muitas vezes, para participarem desses protestos. Segundo Castells, o medo e o entusiasmo movem as pessoas a isso (p. 22). Quando superam o medo, que é paralisante, desenvolvem a raiva e dispõemse a correr riscos, em seguida são tomadas por entusiasmo e esperança, antevendo uma recompensa. A comunicação veloz faz com que a informação de alguém sofrendo injustiça se espalhe rapidamente e logo outras pessoas tomem conhecimento e quando se identificam com a vítima, querem agir.

Castells conclui que o domínio da sociedade em rede atual está nas mãos de quem elabora as redes de que dependemos (governo, mídia, finanças etc.) e nas de quem cria relações entre essas redes (p.17). Ir contra esse poder, então, consistirá na reprogramação das redes em torno de outros ideais e valores. A liberdade da comunicação da internet é ferramenta poderosa para esse fim.

O sociólogo espanhol sugere que esses movimentos sociais analisados por ele nascem da profunda desconfiança nas instituições políticas, da crise de legitimidade dos representantes do povo (p.161). Entre as características comuns aos movimentos elencados por ele estão: uso das redes de comunicação da internet, ausência de uma liderança formal, repercussão local e global, entre outras. $\mathrm{O}$ autor comenta que a ausência de um líder formal reduz a ameaça de repreensão, ao mesmo tempo em que aumenta a oportunidade de mais gente participar do movimento, além da motivação da falta de confiança nas formas de delegação de poder (p. 164). A conexão global possibilita a troca de experiências e a identificação com os problemas de outras comunidades.

O fato de os manifestantes não defenderem uma causa única faz com que atraiam muitas pessoas, mas ao mesmo tempo dificulta a concretização de um projeto para atendimento das reivindicações. Além disso, dificilmente são admitidos em partidos 
políticos, embora sofram algum assédio do marketing político. Contudo, Castells avalia que a implementação do que é reivindicado depende da "permeabilidade das instituições políticas às demandas do movimento" (p.175) e da negociação entre esses dois entes. Ele conclui que "a influência dos movimentos sociais sobre a política e os programas de governo depende amplamente de sua contribuição potencial para as agendas preestabelecidas dos atores políticos” (p.176). Ele critica a falácia de o resultado das eleições expressar a vontade do povo e lembra que tal resultado costuma revelar o poder do dinheiro e da mídia. Há necessidade, por fim, de uma mudança de mente das pessoas, tal mudança seria o legado de um movimento social.

Na avaliação que ele faz sobre o movimento ocorrido no Brasil em 2013, Castells ressalta que a indignação começou com o aumento da tarifa de ônibus, mas que ao lado dessa reivindicação, estava a defesa da dignidade do ser humano que se sente desrespeitado pela precariedade dos serviços públicos. Menciona, ainda, a decepção com a transformação do evento da Copa do Mundo numa oportunidade para desvio de recursos públicos (p.183). Contudo, o que mais lhe chamou a atenção foi a reação da Presidente da República (p. 184) que disse ter a obrigação de ouvir a voz das ruas. Foi a primeira vez, nos movimentos estudados por ele desde 2010, que a autoridade máxima do país se manifestava dessa forma. Importante também foi a proposta feita por Dilma Rousseff de realização de um plebiscito sobre a reforma política. Tais atitudes, segundo ele, causaram inquietação na classe política, uma vez que o movimento social estava alcançando a Presidente da República, essa aliança gerava uma esperança de mudança social palpável.

A esse respeito, Charaudeau (2006) fala que a massa se transformou em grupos que têm consciência do seu direito de reivindicar e de seu poder de pressionar a autoridade política. A capacidade de pressionar viria da cumplicidade da mídia. Ele fala também da fragmentação de comportamentos e opiniões dos indivíduos que protestam. (2006, p. 263). 


\subsection{O Deputado Federal como Representante do Povo}

\subsubsection{Regime Representativo}

Após a substituição do direito divino dos reis pela soberania popular e, diante da impossibilidade de uma democracia direta, surgiram as bases constitucionais do regime representativo. Tal regime designa o sistema constitucional em que o povo se governa por meio de seus eleitos. A participação dos cidadãos se dá por intermédio do voto. $\mathrm{O}$ Parlamento, como corpo político, representaria a vontade da nação. O parlamentar, mesmo sendo eleito por um determinado estado, é representante da nação. O povo pode fiscalizar e cobrar o cumprimento de promessas de seus eleitos, estes com o desejo de serem reeleitos temem agir contra a vontade de quem os elegeu.

\subsubsection{Partidos Políticos}

Os partidos políticos têm a finalidade de conquistar o poder, realizar ideias e angariar adeptos (AZAMBUJA, 2008, p. 346). Eles constituem a opinião pública organizada, são meios de expressão e de ação. São, ainda, um agrupamento de cidadãos com ideias políticas idênticas que veem em suas bandeiras um meio para solucionar seus problemas. Ao votar contra ou a favor de projetos de lei, ao derrubar vetos presidenciais, ao se colocarem em obstrução em votações, eles interferem diretamente no governo.

Para Azambuja (2008, p. 350), os partidos políticos têm o mérito de tornar o regime representativo mais democrático, pois os eleitos assumem o compromisso de governar de acordo com o programa apresentado na campanha eleitoral. Afastar-se da opinião pública que os elegeu poderá gerar retaliações morais e manifestações de protesto populares. Uma forma de retaliação é deixar de votar naquele político, outra é pedir a desfiliação do partido. O povo pode exigir fidelidade aos programas propostos e nem por isso os governantes ficam diminuídos, "pois só se exige que permaneçam leais às ideias que livremente adotaram e publicamente prometeram defender e realizar”. ( p. 351). Os partidos políticos seriam, dessa forma, essenciais para o governo popular. 


\subsubsection{O Papel do Deputado Federal}

Segundo a Constituição Federal, o Poder Legislativo é exercido pelo Congresso Nacional, que se compõe da Câmara dos Deputados e do Senado Federal.

Eleito para um mandato de quatro anos, o Deputado Federal é o representante do povo no Poder Legislativo. Na Câmara, cada estado possui uma quantidade de deputados proporcional à sua respectiva população, sendo no mínimo oito e no máximo 70 em um total de 513 parlamentares.

Entre as atribuições dos Deputados Federais estão: a proposição, discussão e aprovação de leis; a fiscalização da aplicação de recursos públicos; a aprovação da lei orçamentária anual. Além disso, cabe privativamente à Câmara dos Deputados autorizar a instauração de processo contra o Presidente, o Vice-Presidente da República e os Ministros de Estado. Os parlamentares podem ainda convocar Ministros e titulares de órgãos subordinados à Presidência da República para prestar informações sobre assunto determinado.

Quanto ao uso da palavra, temos que os Líderes poderão falar a qualquer tempo da sessão pessoalmente, ou mediante delegação escrita a Vice-Líder, podendo fazer comunicações destinadas ao debate em torno de assuntos de relevância nacional. Eles falam em nome de seu partido ou bloco parlamentar (união de dois ou mais partidos durante uma legislatura). Os demais Deputados devem fazer inscrição junto a Mesa Diretora para poderem se

pronunciar nas diversas fases das sessões. Nos discursos analisados nesta pesquisa há falas de líderes e também de parlamentares que falam somente por si.

\subsubsection{Das Sessões da Câmara dos Deputados}

As sessões da Câmara dos Deputados são, de acordo com o Regimento Interno, deliberativas ou não deliberativas:

- Deliberativas:

a) ordinárias, as de qualquer sessão legislativa, realizadas apenas uma vez por dia, de terça a quinta-feira, iniciando-se às quatorze horas;

b) extraordinárias, as realizadas em dias ou horas diversos dos prefixados para as ordinárias; 


\section{- Não deliberativas:}

a) de debates, as realizadas de forma idêntica às ordinárias, porém sem Ordem do Dia, apenas uma vez às segundas-feiras e às sextas-feiras, iniciando-se às quatorze horas nas segundas e às nove horas nas sextas-feiras, disciplinando o Presidente da Câmara dos Deputados o tempo que corresponderia à Ordem do Dia, podendo os Líderes delegar a membros de suas bancadas o tempo relativo às Comunicações de Lideranças;

b) solenes, as realizadas para grandes comemorações ou para homenagens especiais;

As sessões ordinárias terão duração de cinco horas e constarão de:

I - Pequeno Expediente, com duração de sessenta minutos improrrogáveis, destinado à matéria do expediente e aos oradores inscritos que tenham comunicação a fazer;

II - Grande Expediente, a iniciar-se às dez ou às quinze horas, conforme o caso, com duração improrrogável de cinqüenta minutos, distribuída entre os oradores inscritos;

III - Ordem do Dia, a iniciar-se às dezesseis horas, com duração de três horas prorrogáveis, para apreciação da pauta;

IV - Comunicações Parlamentares, desde que haja tempo, destinadas a representantes de Partidos e Blocos Parlamentares, alternadamente, indicados pelos Líderes.

Em qualquer tempo da sessão, os Líderes, pessoalmente, ou mediante delegação escrita a Vice-Líder, poderão fazer comunicações destinadas ao debate em torno de assuntos de relevância nacional.

O Presidente da Câmara dos Deputados poderá determinar, a fim de adequá-la às necessidades da Casa, que a Ordem do Dia absorva o tempo destinado aos oradores do Grande Expediente.

O Presidente da Câmara dos Deputados poderá não designar Ordem do Dia para sessões ordinárias, que se converterão em sessões de debates. 
A sessão extraordinária, com duração de quatro horas, será destinada exclusivamente à discussão e votação das matérias constantes da Ordem do Dia.

As sessões serão públicas, mas excepcionalmente poderão ser secretas, quando assim deliberado pelo Plenário.

\subsection{Discurso Político}

Estudando a concepção do linguista Patrick Charaudeau (2006) de discurso político, vemos que o discurso político é onde o jogo de máscaras está presente e que não se deve tomar ingenuamente o que se diz ao pé da letra. O autor lembra que "no que é dito, há sempre o que é dito e o que não o é, um não dito que, entretanto, também se diz" (Prólogo). O título original da obra traz a expressão "as máscaras do poder".

A ação política precisaria da presença do outro para acontecer. Charaudeau retoma essa visão e vai além, trata da relação de poder entre quem fala e seu interlocutor (2006, p. 17). Para Arendt (2005 apud Torres, 2007) é "como se toda ação estivesse divida em duas partes: o começo, feito por uma só pessoa, e a realização a qual muitos aderem”. Dessa forma, a ação política é uma ação em conjunto, não ocorre no isolamento, mas mediante acordo entre iguais. Assim, uma proposição legislativa pode surgir pela iniciativa de um parlamentar, mas para ser aprovada e virar lei precisa do debate e da concordância de um conjunto de deputados. Da mesma forma, os manifestantes se uniram com suas mais diversas reivindicações e ocuparam o espaço público para fazer os protestos.

Além disso, é preciso ter em mente o papel importante da linguagem na ação política, uma vez que para que haja decisão coletiva, faz-se necessário um consenso que ocorre num espaço de discussão por meio do discurso. Charaudeau ressalta a necessidade dos representantes do povo prestarem contas aos seus representados (2006, p.18). O político eleito pela vontade do cidadão deveria decidir em consonância com o desejo do povo que o elegeu, o que nem sempre é possível. Assim, por meio de sua fala, o político buscaria a adesão do cidadão ao que ele está defendendo na tribuna (2006, p.19). 
O linguista francês menciona a situação de ações de protesto e compara os efeitos da palavra e da ação. Assim, para acalmar a população que protesta, meras palavras de persuasão não seriam suficientes se não vierem acompanhadas de alguma medida que atenda às suas reivindicações (ação). Dessa maneira, nos discursos analisados temos o que os parlamentares chamam de "pauta positiva", ou seja, a aprovação ou rejeição de projetos, a criação de leis que venham ao encontro do anseio popular, isto é, a palavra acompanhada da ação.

A legitimação desse poder de representar o povo viria do livre consentimento, segundo Arendt (1972 apud Charaudeau, 2006), ou da violência legítima, segundo Weber (1963-2003 apud Charaudeau, 2006). Assim, no primeiro caso é a linguagem que domina e no segundo, a ação. Charaudeau afirma, no entanto, que a linguagem motiva a ação e que “a ação política e o discurso político estão indissociavelmente ligados” (2006, p. 39). Citando Arendt (1972 apud Charaudeau, 2006, p. 42), temos que "o ato não adquire sentido senão pela palavra na qual o agente identifica-se como ator, anunciando o que ele faz, o que ele fez, o que ele quer fazer". Sendo assim, não basta voltar atrás no aumento da passagem de ônibus, é preciso falar a respeito e, mais que anunciar, discorrer sobre os motivos de tal decisão.

O político ao discursar na tribuna do plenário da Câmara dos Deputados, sabe que sua fala está sendo transmitida pela televisão e seu discurso será divulgado no rádio e na imprensa escrita, com isso, como afirma Charaudeau, ele age com prudência ao escolher as palavras (2006, p.35).

Ainda a respeito do falar dos políticos, a nova contribuição proposta por Norman e Isabela Fairclough no livro publicado em 2012 é analisar o discurso político como forma de argumentação, que pode ser contra ou a favor de algo e que serve para basear a tomada de decisões. As escolhas políticas são feitas com base na argumentação prática. Os autores defendem que a consciência dessa natureza argumentativa do discurso político é essencial para a análise desse tipo de texto. O propósito desses discursos é "convencer uma audiência de que algo está certo ou que certo ponto de vista é o verdadeiro, assim o efeito perlocucionário está associado à argumentação" (Fairclough; Fairclough, 2012, p.18). 
Cada sociedade, cada grupo humano deliberaria sobre ações que eles podem fazer e sobre o que pode resultar de sua agência. E as ações são resultado de deliberações. Dessa forma, devido à importância da deliberação na política, é importante a análise do discurso e da argumentação principalmente.

Esses autores falam, ainda, que as análises de discursos políticos têm privilegiado a representação em detrimento da ação. A proposta é estudar a representação subordinada à questão da ação, ou seja, estar atento ao fato de que em política as questões e debates existem para fundamentar decisões, o que fazer, isto é, para auxiliar na ação (p. 20).

A linguagem é uma forma de ação, envolve estratégias fora do discurso para provocar mudanças. A ação política deve ser estratégica e não o discurso em si. A política envolve fazer escolhas, tomar decisões em resposta a alguma situação. Isso envolve defender pontos de vista em situações de conflito, distribuir recursos escassos (orçamento). Muitas vezes, os políticos precisam agir com urgência, dependendo da situação, uma resposta rápida é esperada.

Bauman (1999, p. 2-3) defende uma reinvenção política em que a sociedade civil possa agir coletivamente por meio de instituições, trazendo para esfera pública os problemas que ela crê mereçam ser discutidos. Para ele, deve haver uma deliberação coletiva.

Ainda tratando do que nos faz agir, consideramos ou não algo um problema a ser solucionado de acordo com nossos valores, com aquilo que é importante pra nós. Razões externas versus razões internas. Obrigações versus vontades. Assim, nossas ações são motivadas por nossos valores, com aquilo que é caro pra nós. $\mathrm{O}$ agente social, então, agiria de acordo com os valores morais internalizados por ele, no entanto, ainda que ele não tenha essa motivação em realizar determinada ação, os valores, compromissos e obrigações ainda funcionariam como razões externas que o fariam agir.

Fairclough e Fairclough (2012) propõem juntar a análise das representações com análise da argumentação prática, isso enriqueceria a análise do discurso. O poder provê o agente social com razões para agir, razões para obedecer ou ir contra uma ordem vigente. 
Por isso, deve-se estudar o poder e a argumentação juntos. As chamadas razões externas vão desde promessas de campanha até valores sociais e morais reconhecidos como legítimos. Os valores dos políticos, para os autores, apareceriam nas premissas de circunstância e nas premissas de valor.

Eles falam de cidadãos que cobram de seus políticos o cumprimento de compromissos, questionando a violação de compromissos com justiça. Os autores veem os debates como tipos de atividade inseridos no gênero deliberação. Somente debates sobre o que deve ser feito em dada situação são deliberativos (aquecimento global e o que fazer para detê-lo, por exemplo). No caso dos protestos analisados nesta pesquisa, temos cidadãos reivindicando uma redução das tarifas de transporte público, entre outras ações do governo e os parlamentares debatendo que medidas o Congresso poderia tomar para atender essas reivindicações.

Para os autores, a deliberação consiste de estágios: começam com a abertura (questão), em seguida há a fase de informação, depois se segue a proposta, as considerações e revisão do que foi proposto, a confirmação (aceitação ou rejeição) e finalmente o fechamento da deliberação.

Argumentam que a deliberação é uma parte importante do discurso político, tendo em vista a natureza cooperativa que leva à tomada de decisões na política. Os conflitos, acordos e desacordos cooperam para a chegada a um denominador comum. Embora isso possa ser visto mais claramente na Ordem do Dia ao observamos o parlamento brasileiro, a análise da fala dos líderes partidários e dos demais deputados feita nesta pesquisa revela o posicionamento e as propostas apresentadas pelos parlamentares para lidar com a situação que foi criada com as manifestações populares nas ruas. A condição de risco e urgência, mencionada por Chouliaraki e Fairclough (1999), estava presente nos discursos analisados.

\subsection{Modernidade, Confiança e Poder}

Quanto às mudanças sociais provocadas pela globalização, Giddens (1991) fala de como a sociedade é afetada pelas mudanças trazidas pela modernidade e, posteriormente, 
pela pós-modernidade. Primeiramente, houve um deslocamento de um tempo de manufatura de bens materiais para relacionamentos centrados na informação (GIDDENS, 1991, p.8). Constata que a rápida transformação social na era moderna ocorre na ordem industrial.

A era moderna traz um desencaixe do tempo e do espaço, uma descontinuidade. Giddens aborda as transformações sofridas pela sociedade na era moderna. Ao mesmo tempo em que provocou uma ruptura com várias tradições, criou uma interconexão em nível global e gerou mudanças em características pessoais da vida cotidiana.

$\mathrm{O}$ autor ressalta a rapidez extrema com que as mudanças acontecem na modernidade. Além disso, “conforme diferentes áreas do globo são postas em interconexão, ondas de transformação social penetram através de virtualmente toda a superfície da Terra” (GIDDENS 1991, p.12). Tal característica lembra os acontecimentos da chamada primavera árabe, em que movimentos de protesto que destituíram governantes, serviram de inspiração a outras manifestações ao redor do globo.

Os fundadores clássicos da sociologia não conseguiram prever aspectos negativos que a modernidade traria (prejuízo ao meio ambiente, totalitarismo político, indústria de guerra etc.), eles previam uma época essencialmente pacífica. No entanto, segundo o autor, temos um mundo hoje perigoso, cuja perda da crença no "progresso" fundamenta a dissolução de "narrativas" da história. A modernidade contém ainda a ordem capitalista, o industrialismo, a racionalização e o controle racional da informação.

Giddens (1991) fala do questionamento se os conhecimentos sociológicos produziriam ou não um controle sobre as instituições sociais, até que ponto esse conhecimento pode ser usado para intervir na vida social. Da mesma maneira, podemos pensar nos estudos de Análise do Discurso Crítica como formas de compreender e transformar situações sociais. Ele conclui que há uma reflexividade, conhecimentos e termos transitam dentro e fora do âmbito da vida social.

Na modernidade, há um dinamismo, uma conexão do local com o global. O objeto desta pesquisa pode ter sofrido influência da "primavera árabe" e das manifestações de Wall Street, por exemplo. Ele fala do "deslocamento das relações sociais de contextos locais para extensões indefinidas de tempo-espaço", diante dessa mudança, ele trata do 
papel do dinheiro que estaria associado "à distância espacial entre o indivíduo e sua posse" (GIDDENS 1991, p. 27), a relação econômica, não precisa mais ser pessoal, o dinheiro passa a ser representado em números, é uma informação. Ele é fundamental para o que Giddens chama de desencaixe, ou seja, essa ruptura ou distanciamento com que as relações sociais passaram a ocorrer.

Ele trata então da confiança, fundamental nas instituições da modernidade. Está relacionada à consciência do risco, criada pela falta de informação plena sobre algo e ausência da relação tempo-espaço e está ligada à fé em princípios e na credibilidade de uma pessoa ou sistema. Distingue confiança e crença. No caso da confiança, há um cálculo de riscos, em tal situação o autor percebe que essa percepção de risco toma lugar do destino. Há confiança com rosto e sem rosto. Ao tratar da confiança depositada em sistemas de perícia e na ciência, ele lembra que só se exige confiança onde há ignorância. Assim, por não entender como funciona um sistema hidráulico, confiamos no bombeiro, por não termos feito medicina, confiamos no médico. É necessário não saber todos os riscos e erros e outras situações que podem acontecer para continuarmos colocando nossa confiança em tais peritos. O contrário de confiança não seria desconfiança, mas o pavor existencial, uma ansiedade tamanha que afetaria a vida do indivíduo de forma contundente.

Neste estudo, buscarei investigar a confiança no sistema político, na instituição Congresso Nacional e nos parlamentares. Verificarei como os protestos podem representar uma quebra dessa confiança e como os discursos dos Deputados tratam disso.

Bauman (2001) trata da modernidade fluida que produziu uma mudança profunda na sociedade e necessita que os velhos conceitos sejam repensados a fim de que sejam confirmados ou descartados. Assim, como Giddens, ele também trata da velocidade nesse tempo, que chegou ao nível máximo, a instantaneidade. Para ele, esse aspecto garante aos detentores de poder a inacessibilidade, podem fugir do alcance a qualquer momento. As principais técnicas de poder passam a ser: a fuga, a astúcia, o desvio, a rejeição territorial e a evitação.

A guerra nesse novo tempo visa destruir barreiras que impedem o fluxo global, principalmente o livre comércio. Os laços sociais mais densos também são um obstáculo a ser eliminado. Enfim, qualquer barreira ou fronteira fortificada deve ceder à fluidez do 
poder.

Ao tratar de libertação, Bauman diz que é relativamente difícil mobilizar uma massa que busque essa liberdade, pois é possível que pessoas vivendo em escravidão sintam-se livres e consequentemente não sintam a necessidade de libertação. O equilíbrio seria alcançado ampliando-se o campo de ação e reduzindo-se os desejos.

Duas características da sociedade moderna são: declínio da ilusão de um estado de perfeição a ser atingido e privatização das tarefas e deveres modernizantes, o que antes era propriedade coletiva passou a ser individualizado. Assim, o indivíduo assume responsabilidades e consequências e passa a ser oposto ao cidadão. Coloca-se sobre o homem o peso de se autoafirmar, e essa é uma luta solitária. A individualização destrói a cidadania. A busca do bem estar social da cidade ou comunidade é substituída por interesses individuais. A esfera pública passa a ser invadida por aflições individuais. Nesse ponto, recordo-me do caráter difuso das manifestações de 2013: não havia uma pauta única de reivindicação, mas cada grupo defendia um interesse (cancelamento do aumento da passagem de ônibus, votação da PEC 37, direitos dos homossexuais etc.), eram interesses específicos de grupos que se uniram em uma só mobilização.

Bauman (2001) constata que, no tempo moderno, o ser humano se consome em meio às escolhas que tem que fazer e na decisão de seu objetivo de vida. A observação da experiência alheia aparece como um auxílio, a vida privada se torna pública (reality shows, entrevistas, biografias). Dessa forma, a esfera pública é tomada por dramas privados em vez de a Política se ocupar de traduzir problemas privados em questões públicas. 


\section{Capítulo 2}

\section{Base Teórica}

Este capítulo busca apresentar os pressupostos teóricos em que está ancorada esta dissertação. Foi dividido em cinco seções. A primeira trata da Linguística SistêmicoFuncional e das Metafunções utilizadas na análise dos dados desta pesquisa; ; já a segunda traz a representação dos atores sociais de acordo com van Leeuwen (2008); a terceira fala da contribuição de Fairclough (2003) a respeito de representação; a quarta fala da contribuição da Análise de Discurso Crítica (ADC) para este trabalho e, por último, a quinta seção apresenta a integração das abordagens teóricas.

\subsection{Linguística Sistêmico-Funcional}

Os estudos de Fairclough buscam fazer uma análise macro, ou seja, da exterioridade da linguagem, considerando o aspecto social, sem, no entanto, esquecer-se da gramática, pois, segundo ele, para alcançar os efeitos causais e ideológicos é preciso ligar a microanálise a macroanálise e perceber como as relações de poder transparecem nas estruturas linguísticas (FAIRCLOUGH, 2003, p.15). E a teoria gramatical que se alinha a esse propósito, segundo Fairclough (1999, p. 139) é a Linguística Sistêmico-Funcional.

A Linguística Sistêmico-Funcional (LSF), proposta por Halliday (1994), serve como principal instrumento gramatical para desvelar as intenções e ideologias subjacentes à linguagem. Ela parte do significado que é o que vai determinar a forma. Assim, conforme sua necessidade e, de acordo com o contexto específico, o falante faz as suas escolhas. A teoria sistêmica hallidiana envolve a correlação entre estrutura linguística e estrutura social, isto é, relaciona contextualmente a interioridade e a exterioridade da linguagem.

Segundo Halliday (2014, p.3), texto é a linguagem funcionando num contexto, é um processo de criar sentido dentro de um contexto. A Linguística Sistêmico-Funcional proposta por esse autor vai estudar as palavras, considerando sua forma de uso, sua função dentro do texto. Ele vê a linguagem como um grande sistema em que cada parte tem papel 
na produção de significado para quem lê ou escuta o texto. O sentido é então formado pela combinação dos termos. Não somente a escolha desses, mas a posição em que os colocamos e ligados a que outras expressões irão determinar a significação.

De acordo com Halliday, a oração é uma unidade em que três tipos de significado se combinam. São três estruturas diferentes revelando um tipo de organização semântica cada (2014, p. 88). Essas três linhas são chamadas de metafunções e são: Metafunção Textual, Metafunção Interpessoal e Metafunção Ideacional. Elas se realizam simultaneamente nos textos. A função ideacional diz respeito à representação da experiência, a função interpessoal manifesta a interação entre os participantes da situação e se materializa por meio das escolhas de modo e modalidade, e, finalmente, a função textual trata da organização do texto como mensagem, dos aspectos relacionados à estrutura linguística, conforme ilustrado no quadro a seguir.

Quadro 1- Metafunções e variáveis de contexto

\begin{tabular}{|c|c|l|}
\hline Variáveis de contexto & Metafunções & $\begin{array}{l}\text { Realizações } \\
\text { lexicogramaticais }\end{array}$ \\
\hline Campo & Ideacional & Transitividade \\
\hline Relações & Interpessoal & Modo e Modalidade \\
\hline Modo & Textual & Tema e Rema \\
\hline & & \\
\hline
\end{tabular}

Fonte:BARBARA E MACÊDO, 2009.

Tendo em vista que o objetivo de meu estudo é examinar a representação do povo nos discursos parlamentares, concluí que a Metafunção Ideacional me revelaria quais os tipos de processos escolhidos pelos deputados, que participantes estavam envolvidos nas falas e em que circunstâncias. Além do mais, a Metafunção Interpessoal também se 
mostraria útil, levando-se em consideração que o discurso político é uma interação com o público que lhes assiste.

\subsubsection{Metafunção Ideacional}

A metafunção ideacional é aquela que nos permite representar as experiências tanto internas (consciência, sentimentos) quanto externas (eventos do mundo físico). A linguagem constrói a realidade e transmite esse conteúdo para que outras pessoas o entendam. Halliday (2014, p. 213) afirma que a experiência é um fluxo de eventos e que a gramática vem colocar uma ordem linguística na nossa experiência de variações intermináveis. Esse sistema gramatical é o da Transitividade.

O Sistema da Transitividade traz a oração como representação e revela-se por meio de três elementos: participantes, processos e circunstâncias.

Quadro 2- Sistema da Transitividade

\begin{tabular}{|l|l|}
\hline \multicolumn{1}{|c|}{ Tipo de elemento } & Tipicamente realizado por: \\
\hline (i) processo & Grupo verbal \\
\hline (ii) participante & Grupo nominal \\
\hline (iii) circunstância & $\begin{array}{l}\text { Grupo adverbial ou sintagma } \\
\text { preposicional }\end{array}$ \\
\hline
\end{tabular}

Fonte: Halliday, 2004, p. 177

Os processos podem representar a experiência de seis formas diferentes, são: materiais, mentais, relacionais, verbais, comportamentais e existenciais. Processos materiais tratam de experiências exteriores, já os mentais, tratam de experiências interiores ou processos de consciência. O primeiro fala do fazer e acontecer, o segundo está ligado às emoções.

Exemplo: "A gente tem que ouvir a voz do povo e oferecer a resposta correta à sociedade"

\begin{tabular}{|l|l|}
\hline Processo Material: & oferecer \\
\hline Processo Mental: & ouvir \\
\hline
\end{tabular}


Além dos processos materiais e mentais, há também os relacionais, que são processos de ser e de ter. Usados para caracterizar e identificar. Comparado ao processo material, o relacional agiria de forma mais "inerte", no sentido em que não há uma dinâmica ou transformação do participante. Para Halliday, ele estaria bem próximo dos processos mentais.

Exemplos:

"As manifestações são legítimas".

Processo Relacional atributivo: são

Além desses tipos de processos, há três tipos subsidiários que se encontram nas fronteiras: comportamental (entre material e mental), verbal (entre mental e relacional) e existencial (entre relacional e material). Os comportamentais são processos do comportamento tipicamente humano como suspirar, sonhar, tossir. Seu participante é chamado comportante. Os verbais, por sua vez, são os processos de dizer; eles podem designar atividades (elogiar, criticar, insultar) ou semiose (prometer, ameaçar, persuadir, implorar). Quem diz é chamado dizente e o que é dito, verbiagem. Os existenciais, finalmente, representam algo que existe e seu verbo típico é "haver" e não apresentam sujeito.

Exemplos:

O Brasil acordou nesta terça-feira mais forte com as manifestações.

A sociedade está dizendo para nós que está cansada do jeito que a gente faz política.

Houve manifestação contra a Rede Globo, houve manifestação a favor dos indígenas, há o debate sobre a questão dos direitos humanos.

\begin{tabular}{|l|l|}
\hline Processo Comportamental: & acordou \\
\hline Processo Verbal: & está dizendo \\
\hline Processos Existenciais: & Houve, há \\
\hline
\end{tabular}


Halliday (2014) explica que não há primazia de um tipo de processo sobre outro, pois o modelo de representação da experiência pela gramática da transitividade são regiões num espaço contínuo circular, em uma comparação com o espectro das cores.

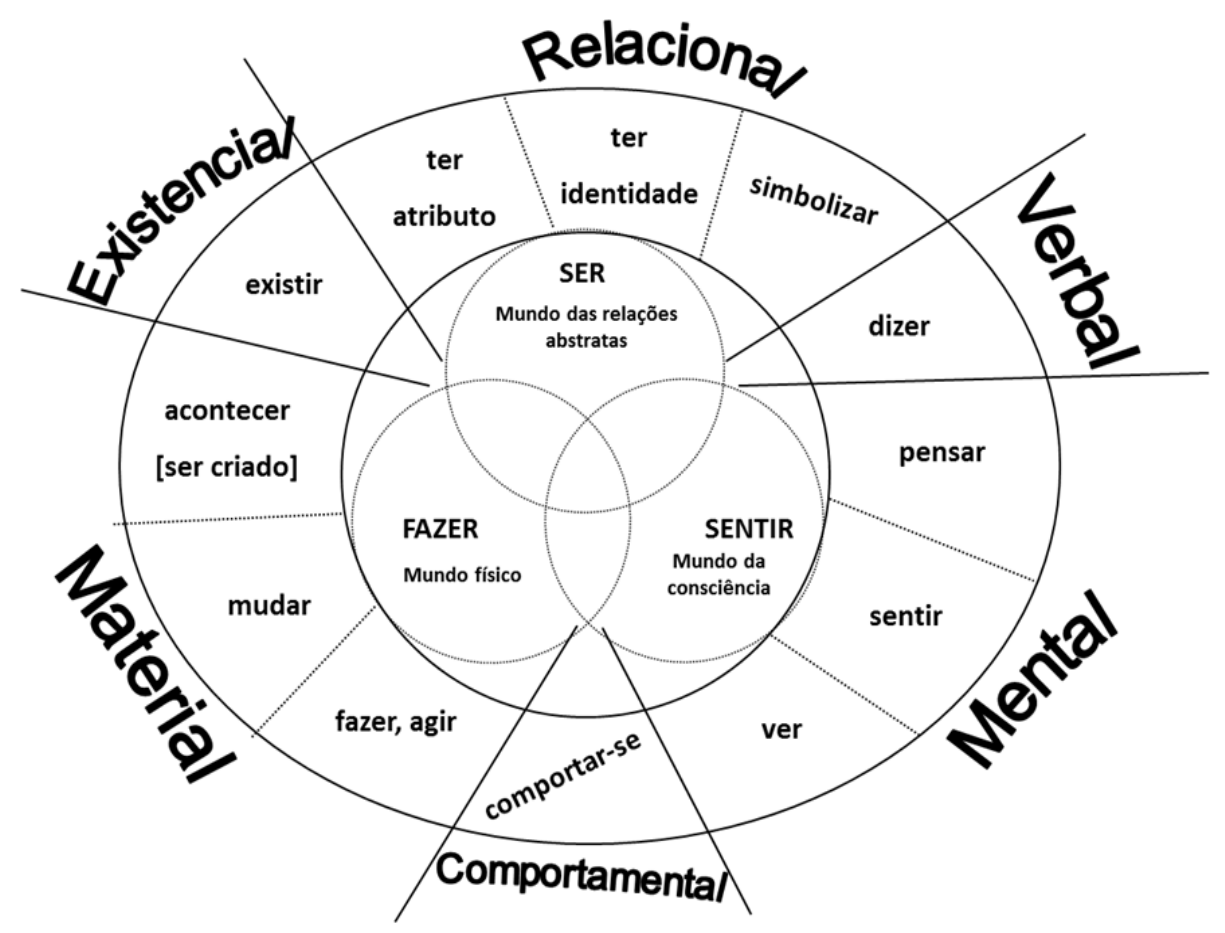

Figura 1-As Metafunções. Adaptado de Halliday (2014).

Considerando que o Sistema da Transitividade será uma das bases principais deste estudo, explicarei a seguir mais detidamente cada tipo de processo.

\subsubsection{Processos Materiais}

Processos materiais são processos do fazer, representam ações concretas. Basicamente, alguém realiza algo e outro alguém sofre essa ação. (Eggins, 2004, p.215). Possuem como participante um Ator, mesmo que esse não seja mencionado na sentença, e uma Meta. Podem contar ainda com uma Circunstância. 
Quadro 3 - Processos Materiais.

\begin{tabular}{|l|l|l|l|}
\hline A velha & costurava & a blusa & em silêncio. \\
\hline O mendigo & quebrou & a garrafa. & \\
\hline O fogo & destruiu & a plantação. & \\
\hline ATOR & $\begin{array}{l}\text { PROCESSO } \\
\text { MATERIAL }\end{array}$ & META & CIRCUNSTÂNCIA \\
\hline
\end{tabular}

Os processos materiais podem ser divididos em várias subcategorias. No entanto, nesta explanação me deterei nas duas principais categorias quais sejam os criativos e os transformativos (THOMPSON, 2014, p 96).

Os criativos são aqueles em que Ator ou Meta é trazido à existência ou construído com o desenrolar do processo. Já nos transformativos, o desenrolar do processo gera uma transformação no Ator ou Meta pré-existente.

Exemplos:

Sabrina fez o bolo de aniversário. (Criativo)

O mendigo quebrou a garrafa. (transformativo)

O ator pode não aparecer na sentença. Isso ocorre, por exemplo, nas orações na voz passiva. A opção pela voz passiva e consequente ocultamento do Ator é escolha do falante.

\begin{tabular}{|l|l|}
\hline O homem & foi assassinado. \\
\hline Meta & Processo Material \\
\hline
\end{tabular}

A combinação dessa análise com o Sistema de Modo nos mostra que a Meta transforma-se em Sujeito.

\begin{tabular}{|l|l|l|l|}
\hline O vândalo & foi & detido & pelo policial \\
\hline Meta & Processo material & \multicolumn{2}{|l|}{} \\
\hline Sujeito & Finito & Predicador & Ator \\
\hline
\end{tabular}


Além do Ator e da Meta, os processos materiais podem apresentar Escopo, Beneficiário e Atributo.

O Escopo é o participante que não é afetado pela performance do processo (Fuzer\&Cabral, 2010, p.38).

\begin{tabular}{|l|l|l|l|}
\hline O rapaz & subiu & os degraus & rapidamente. \\
\hline Ator & Processo Material & Escopo & Adjunto \\
\hline
\end{tabular}

O Beneficiário, por sua vez, é quem recebe ou se beneficia de um processo.

\begin{tabular}{|l|l|l|l|}
\hline $\begin{array}{l}\text { Os milhares de } \\
\text { manifestantes }\end{array}$ & deram & um duro recado & aos governantes \\
\hline Ator & Processo Material & Meta & Beneficiário \\
\hline
\end{tabular}

O Atributo, embora seja mais afeito às orações relacionais, tem lugar nas materiais quando o resultado do processo é algo elaborado, seria o estado em que Ator ou Meta se encontram depois de completado o processo.

\begin{tabular}{|l|l|l|l|}
\hline Ela & deixou & a casa & impecável. \\
\hline Ator & Processo Material & Meta & Atributo \\
\hline
\end{tabular}

Além de observar os tipos de processos e quais participantes estão envolvidos em um texto, é importante investigar as circunstâncias em que a ação ocorre. Geralmente, realizadas por grupos adverbiais e preposicionais, as circunstâncias completam o significado proposto pelo falante. No exemplo abaixo, a circunstância tem papel relevante ao incluir no discurso acontecimentos de outros lugares, numa clara comparação entre os governos de duas cidades.

Parabenizo o Presidente em exercício da Casa, o Deputado Andre Vargas, que teve atitude serena, auspiciosa, de compreender a voz das ruas e não empreender uma repressão policial, como foi empreendida em outros lugares deste País. 


\subsubsection{Processos Mentais}

Os processos mentais revelam o mundo interior, os sentimentos e reações. Nesse caso, quem sente, imagina, deseja é chamado de Experienciador e o objeto do sentimento recebe o nome de fenômeno. O experienciador precisa ser humano ou, no caso de um ser inanimado, possuir traços de humanidade.

Exemplo: A viola chorava ao entardecer.

Geoff Thompson (2004, p. 99) faz a diferenciação dos processos mentais em: perceptivo, emotivo, cognitivo e desiderativo. Perceptivos são os processos de perceber, ouvir, etc. Baseiam-se nos cinco sentidos. Emotivos expressam os vários sentimentos e emoções. Processos mentais cognitivos são os processos de saber, entender, decidir. E, finalmente, os desiderativos exprimem o querer do experienciador.

\begin{tabular}{|l|l|l|}
\hline $\begin{array}{l}\text { Marta } \\
\text { Experienciador }\end{array}$ & $\begin{array}{l}\text { ouviu } \\
\text { Processo Mental } \\
\text { Perceptivo }\end{array}$ & $\begin{array}{l}\text { um barulho ensurdecedor. } \\
\text { Fenômeno }\end{array}$ \\
\hline
\end{tabular}

\begin{tabular}{|l|l|l|} 
Maria & amou & o novo apartamento. \\
\hline Experienciador & Processo Mental Emotivo & Fenômeno \\
\hline
\end{tabular}

\begin{tabular}{|l|l|l|}
\hline O menino & compreendeu & a lição. \\
\hline Experienciador & Processo Mental Cognitivo & Fenômeno \\
\hline
\end{tabular}

\begin{tabular}{|l|l|l|}
\hline O povo & quer & uma saúde melhor. \\
\hline Experienciador & $\begin{array}{l}\text { Processo Mental } \\
\text { Desiderativo }\end{array}$ & Fenômeno \\
\hline
\end{tabular}

\subsubsection{Processos Relacionais}

Os processos relacionais possuem a função de sinalizar a relação entre um ente e seu atributo. São usados para definir, caracterizar e descrever seres ou situações no mundo. Exemplos:

\begin{tabular}{|l|l|l|}
\hline O povo & está & desanimado. \\
\hline Este tecido & é & de ótima qualidade. \\
\hline
\end{tabular}




\begin{tabular}{|l|lr|l|}
\hline Portador & $\begin{array}{l}\text { Processo } \\
\text { Atributivo }\end{array}$ & Relacional & Atributo \\
\hline
\end{tabular}

Eles podem também identificar um ente em relação a outro.

\begin{tabular}{|l|l|l|} 
Dilma & é & a Presidente da República. \\
\hline Identificado & Processo Relacional & Identificador \\
\hline
\end{tabular}

Além do verbo ser, o mais comum, outros verbos ocorrem como processo relacional, tais como: estar, ficar, parecer, tornar-se, permanecer etc.

Halliday (2014, p. 263) divide os processos relacionais em três tipos: intensivo, possessivo e circunstancial e ocorrem em dois modos diferentes: atributiva e identificadora.

\begin{tabular}{|l|l|l|}
\hline & Atributiva & Identificadora \\
\hline Intensiva & Sandra é sábia & $\begin{array}{l}\text { Sandra é a vencedora. } \\
\text { A vencedora é Sandra. }\end{array}$ \\
\hline Possessiva & Pedro tem um violão & O violão é de Pedro. \\
\hline Circunstancial & $\begin{array}{l}\text { A reunião será numa quinta- } \\
\text { feira. }\end{array}$ & $\begin{array}{l}\text { A reunião será em 22 de } \\
\text { outubro. } \\
\text { Em 22 de outubro será a } \\
\text { reunião. }\end{array}$ \\
\hline
\end{tabular}

Adaptada de Halliday 2014, p. 265

Verificar se o processo relacional é atributivo ou identificacional é relativamente fácil, uma forma seria ver se há reversibilidade. São reversíveis os processos relacionais identificacionais. Outro parâmetro é observar se o segundo participante na sentença é um adjetivo, isso indicaria um atributo.

Nas orações relacionais intensivas atributivas, uma classe ou característica é atribuída a um ser.

\begin{tabular}{|l|l|l|}
\hline A juventude & está & indignada. \\
\hline Portador & Proc. Relacional & Atributo \\
\hline
\end{tabular}


Nas intensivas identificadoras, uma entidade é usada para identificar outra, $x$ serve para identificar $y$ (Halliday, 2014, p. 276). Em geral, o grupo nominal que funciona como Identificador é definido, vem precedido de um artigo definido ou outro determinante específico como dêitico (Fuzer\&Cabral, 2010, p.73)

\begin{tabular}{|l|l|l|}
\hline O líder da Minoria & é & o Deputado Nilson Leitão. \\
\hline Identificado & Processo Relacional & Identificador \\
\hline
\end{tabular}

As orações relacionais possessivas expressam uma relação de posse, são tipicamente realizados pelos verbos: ter, possuir e pertencer.

\begin{tabular}{|l|l|l|}
\hline O empresário & possui & uma fortuna. \\
\hline Possuidor & Processo Relacional & Possuído \\
\hline
\end{tabular}

No caso das orações relacionais circunstanciais, a relação diz respeito ao tempo, lugar, maneira ou causa.

\begin{tabular}{|l|l|l|}
\hline $\begin{array}{l}\text { O Congresso sobre } \\
\text { linguagem }\end{array}$ & será & em Santa Maria. \\
\hline Portador & Processo Relacional & Circunstância \\
\hline
\end{tabular}

A observação dos processos relacionais em um discurso permite-nos desvendar a caracterização, definição e avaliação de acontecimentos e pessoas.

\subsubsection{Processos Verbais}

Processos verbais são os processos do dizer. Possibilitam trazer para o discurso a fala de outras pessoas. Os participantes envolvidos nesse tipo de oração são o Dizente (aquele que fala) e a Verbiagem (aquilo que é dito), pode ocorrer ainda o Receptor (aquele para quem a fala é dirigida). O que é falado pode aparecer como Citação (discurso direto) ou Relato (discurso indireto). 


\begin{tabular}{|l|l|l|l|}
\hline A sociedade & está dizendo & para nós & $\begin{array}{l}\text { que está cansada do } \\
\text { jeito que a gente faz } \\
\text { política }\end{array}$ \\
\hline Dizente & Processo Verbal & Receptor & Verbiagem (Relato) \\
\hline
\end{tabular}

\begin{tabular}{|l|l|l|l|}
\hline Ontem & o povo & dizia: & "Fora, Rede Globo". \\
\hline $\begin{array}{l}\text { Circunstância de } \\
\text { tempo }\end{array}$ & Dizente & Processo Verbal & Verbiagem (Citação) \\
\hline
\end{tabular}

A análise desse tipo de processo é importante para checarmos que falas estão inseridas em um discurso.

\subsubsection{Processos Existenciais}

Processos Existenciais são processos de existir e acontecer. Os verbos típicos desse tipo de oração são: haver, existir e ocorrer. O participante implicado nesse caso é chamado de Existente.

\begin{tabular}{|l|l|}
\hline Há & um projeto aqui sobre isso. \\
\hline Proc. Existencial & Existente \\
\hline
\end{tabular}

\begin{tabular}{|l|l|}
\hline Existe & um sentimento da Nação, \\
\hline Proc. Existencial & Existente \\
\hline
\end{tabular}




\subsubsection{Processos Comportamentais}

Os Processos Comportamentais exprimem comportamentos tipicamente humanos. Situam-se entre os processos materiais e os mentais. Seu participante, o Comportante precisa ter algum traço de humanidade.

\begin{tabular}{|l|l|}
\hline Ela & bocejou. \\
\hline Comportante & Processo Comportamental \\
\hline
\end{tabular}

\begin{tabular}{|l|l|}
\hline O Brasil & acordou. \\
\hline Comportante & Processo Comportamental \\
\hline
\end{tabular}

\subsubsection{Metafunção Interpessoal}

A Metafunção Interpessoal trata da linguagem como forma de interação, troca. $\mathrm{O}$ sistema gramatical estudado aí é o do Modo. Nele, poderemos observar como falantes estruturam a linguagem para interagir com seus ouvintes. Assim, relações de poder entre emissor e receptor, bem como as de polidez, subserviência, exigência, pedido, entre outras são codificadas pelos sistemas dessa metafunção.

Nas proposições, as possibilidades intermediárias são os graus de probabilidade (possivelmente, provavelmente, certamente) e de frequência (sempre, frequentemente). Já nas propostas, há graus de obrigação e inclinação. Em trocas de conhecimento, a modalidade é epistêmica, refere-se ao comprometimento com a verdade; em trocas de atividade, a modalidade é deôntica, refere-se ao comprometimento com a obrigatoriedade/necessidade (FAIRCLOUGH, 2003, p. 168).

O estudo do Modo nos auxiliará na verificação do comprometimento dos oradores com aquilo que estão falando. Fairclough (2003, p. 166) lembra que "com o que você se compromete é parte significativa do que você é, logo as escolhas de modalidade nos textos 
podem ser vistas como parte do processo de formação da própria identidade". Tendo em vista, que esta pesquisa analisa a fala de Deputados como líderes de partidos políticos, temos, nesse caso, a construção da identidade e posicionamento do partido.

\subsubsection{Sistema de MODO}

O Sistema de MODO é dividido em duas partes: Modo e Resíduo. O Modo, por sua vez, possui dois elementos: Sujeito e Finito.

O Sujeito é comumente representado por um grupo nominal, pode ser omitido, sendo revelado pela desinência verbal. Já o Finito é a parte do grupo verbal que expressa o tempo, inclui a opinião do falante e a polaridade (Fuzer \&Cabral , 2010, p. 113).

Quanto ao Resíduo, dizemos que é o restante da oração, engloba o Predicador, o Complemento e o Adjunto. O Predicador compreende a parte verbal que sobra quando tiramos o Finito. Ele especifica o que Halliday (2014, p. 151) chama de tempo secundário, a voz (ativa ou passiva) e o processo. O Complemento é o elemento que tem potencial para se tornar Sujeito, é tipicamente um grupo nominal. E por último, os Adjuntos são partículas que não tem possibilidade de se tornarem sujeitos, são normalmente grupos adverbiais e preposicionais, indicam tempo, modo, espaço etc. Abaixo, trago alguns exemplos do corpus desta pesquisa:

\begin{tabular}{|l|l|l|l|}
\hline Queremos & sim & fazer & $\begin{array}{l}\text { uma pauta consonante com } a \\
\text { voz das ruas, mas, ao mesmo } \\
\text { tempo, consagrando as vitórias } \\
\text { adquiridas, porque elas não } \\
\text { vieram de graça. }\end{array}$ \\
\hline Finito & Polaridade & Predicador & Complemento \\
\hline Modo & \multicolumn{1}{|c|}{ Resíduo } \\
\hline
\end{tabular}

\begin{tabular}{|l|l|l|l|l|}
\hline Infelizmente, & senhoras $e$ & esse movimento & chegou & tarde. \\
\hline
\end{tabular}




\begin{tabular}{|l|l|l|l|l|}
\hline & senhores, & & & \\
\hline Adj. Comentário & Vocativo & Sujeito & $\begin{array}{l}\text { Finito }+ \\
\text { Predicador }\end{array}$ & Complemento \\
\hline
\end{tabular}

No exemplo acima, temos a presença do Vocativo, partícula que não faz parte nem do Modo e nem do Resíduo. O uso do Vocativo coloca em evidência aquele para quem é dirigida a fala.

$\mathrm{Na}$ análise da Metafunção Interpessoal é relevante observar o modo escolhido pelo falante (declarativo, interrogativo, imperativo). A entonação também tem papel importante na comunicação, contudo, neste estudo, embora tenha havido consulta ao áudio dos discursos, esse quesito não será considerado.

\subsection{Modalidade}

A Modalidade é o recurso linguístico que permite ao falante expressar julgamento, opinião, avaliação. Outra maneira de definir Modalidade é dizer que é algo que se situa no espaço entre o sim e o não. Quando tratamos de Finito, falamos que a polaridade (negativa ou positiva) era algo demonstrado naquele elemento. Sendo assim, uma sentença será afirmativa ou negativa, mas analisando semanticamente veremos que entre o sim e o não pode haver o talvez, o às vezes, o provavelmente (Thompson, 2004, p. 69), indefinições expressas pela Modalidade.

Assim, entre Vamos votar a PEC 37 esta semana e Não vamos votar a PEC 37 esta semana, temos: A PEC 37 pode ser votada esta semana, Devemos votar a PEC 37 esta semana etc.

Halliday faz distinção entre proposições (quando há troca de informações) e propostas (quando há troca de bens e serviços).

Nas proposições, quando há indeterminação entre o sim e o não, encontramos graus de probabilidade e graus de usualidade, ou seja modalização.

Já nas propostas, o intervalo entre os comandos "Faça isso!" e "Não faça isso!" revela graus de obrigação e graus de inclinação.

Modalização $\rightarrow$ Probabilidade : Isso é provavelmente o que a sociedade espera. Usualidade: Eles geralmente se reunem na Esplanada. 
Modulação $\rightarrow \quad$ Obrigação: Precisamos também estabelecer uma agenda mínima. Inclinação: O Governo está disposto a colocar o projeto em votação.

A modalização pode ser expressa por verbos modais (pode, deve), adjuntos modais (talvez, certamente, sempre), grupos adverbiais (com certeza, sem dúvida) e expressões (é possível, é provável). Da mesma maneira, a modulação pode se dar por meio de verbo modalizador (deve, precisa), adjuntos modais (necessariamente, obrigatoriamente) e expressões (é necessário, é preciso, está inclinado a, está disposto a). (Fuzer\&Cabral, 2010, p. 121).

Os significados interpessoais não estão restritos a apenas um constituinte, mas estão espalhados pela oração. Podem ser cumulativos e ser colocados em diferentes parte da oração (Thompson, 2004, p.69).

É uma reflexão que tem de ser estudada, tem de ser analisada, e, essas ações para responder à sociedade têm de ser praticadas com toda a transparência, porque isso, sem dúvida nenhuma, é o que a sociedade tem nos cobrado.

A modalidade pode ser expressa em diferentes graus (alto, médio, baixo) (Thompson, 2004, p. 72).

Com isso, dizer "com toda a certeza" demonstra um alto grau de probabilidade, maior do que dizer "talvez".

Essa reflexão, com toda a certeza, não pode ser fruto do calor do momento.

A força dessas manifestações talvez tenha assustado a Nação brasileira.

Da mesma maneira que falar "Nós precisamos ouvir esta sociedade" traz um grau maior de obrigação que falar "Nós podemos ouvir a sociedade". 
A análise baseada no Sistema de Modo é, pois, de suma importância para o desvelamento da atitude do falante, para pôr em evidência o grau de comprometimento do orador com seu pronunciamento, de grande valia, portanto, para esta pesquisa.

\subsection{A Representação dos Atores Sociais}

Theo van Leeuwen (2008) trata de como participantes de práticas sociais são representados no discurso. Ele parte de uma análise sociosemântica de como os atores sociais são representados, observando sua importância social e crítica para depois chegar às categorias linguísticas a que estão ligados. Aconselha o analista a não ficar preso a categorias gramaticais, pois elas nem sempre coincidem com a agência sociológica.

\subsubsection{Exclusões e Inclusões}

Van Leeuwen (2008) investiga principalmente inclusões e exclusões, são as principais categorias de sua taxionomia (ver tabela em anexo). Segundo ele, representações incluem e excluem atores sociais para atender interesses e propósitos do autor em relação aos leitores que visa alcançar (p.28). Algumas exclusões podem partir do pressuposto de já serem conhecidas pelo leitor, ou consideradas irrelevantes por quem escreve, outras são intencionais. Algumas exclusões não deixam marcas, excluindo tanto atores sociais, quanto suas atividades (como, por exemplo, o fato de a imprensa não mencionar outros integrantes do conselho deliberativo da Petrobras, ao noticiarem a suposta compra irregular de uma refinaria nos Estados Unidos pela estatal). Essa exclusão radical tem papel importante numa análise que compare diferentes representações de uma mesma prática social, como no caso da minha pesquisa.

Há dois tipos de exclusão: supressão e encobrimento. Na supressão, não há referência alguma a determinados atores sociais no texto, já no encobrimento ou backgrounding, essa exclusão é menos radical, o ator social não aparece ligado diretamente à atividade, mas é mencionado em outro ponto do texto e o leitor pode inferir quem ele seja. 
A supressão pode ocorrer pelo apagamento do agente da passiva, por meio de nominalizações, uso de adjetivos no lugar de verbos. Um exemplo de supressão seria: "No Brasil, preocupação e tensão têm sido expressas a respeito da Copa do Mundo”. (Quem expressa?) Nos discursos parlamentares analisados nesta pesquisa, percebi, por exemplo, que alguns parlamentares mencionam a polícia e outros não. Esse ator social só pode ser conhecido pela comparação de discursos sobre o mesmo evento. Em alguns excertos, não encontramos o povo mencionado, apenas a atividade de manifestar, isso também é uma forma de supressão.

Quando um autor escolhe incluir determinado ator social, temos que examinar de que maneira ele é inserido no texto. $\mathrm{O}$ falante pode escolher generalizar ou especificar atores sociais. A representação pode se dar por termos genéricos (Os deputados estão

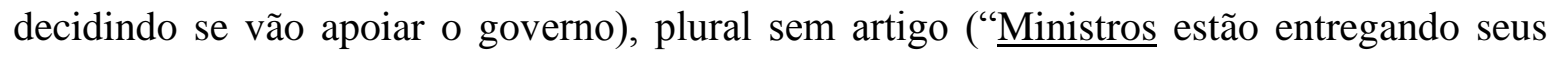
cargos") ou pode-se, por outro lado, usar termos específicos, nomear ( $\underline{\text { A ministra Marta }}$ Suplicy pediu demissão esta tarde).

O falante pode também optar pela ativação ou passivação do ator social. A ativação diz respeito à representação do ator como quem exerce a ação, como a força dinâmica na atividade (p.33), exerce o papel, no Sistema da Transitividade, de Ator, Experienciador, Dizente, Comportante etc. A passivação apresenta o ator como recebedor da ação (Meta, Beneficiário, Alvo). Observe o exemplo abaixo:

\section{A Presidenta Dilma expressou seu apoio aos jovens que protestaram.}

Nesse caso, temos o ator social Presidente Dilma como Dizente e jovens como alvo. Ela age e eles recebem a ação. Numa análise, é preciso observar quem ocupa o lugar de agente e quem ocupa o de paciente. Adjetivos e pronomes possessivos também podem ser usados para apassivar, por isso, van Leeuwen alerta para que o analista não fique preso a categorias gramaticais. Assim, teríamos como exemplo: "a legítima ação dos agentes..." (Quem legitima?) ou "a divulgação de imagens..." - (Quem divulga?). Nosso governo apoia as manifestações pacíficas. (inclui os Deputados da base do governo). 
Outra distinção feita por van Leeuwen (2008, p. 37) é entre Individualização e Assimilação. Podemos nos referir a atores sociais como indivíduos: "O Deputado André Vargas teve atitude serena", ou como grupos: "essa nação”, “os brasileiros”, “a classe média”. A Assimilação pode ainda ser por Agregação, quando há um quantificador (40\% da população) ou por Coletivização (a juventude brasileira, pesquisadores). Agregação é usada para regular uma prática e fabricar uma opinião consensual. Trata do que a maioria considera legítimo.

Outra subdivisão categórica é a da Diferenciação. Nesse caso, há um contraste entre dois entes, o eu e os outros. Nos discursos analisados, algumas vezes encontramos essa situação em que o político distingue o povo nas ruas e os parlamentares lá dentro.

“A população não se sente representada e nós aqui temos dificuldade de fazer valer os nossos mandatos".

Os atores podem também ser impessoalizados, isto é, pode ser atribuído a eles um nome que não possua um componente humano. Isso pode ocorrer por Abstração e por Objetivação. Na Abstração, o ator é substituído por um nome que define uma qualidade atribuída a ele. Assim, imigrantes considerados problemáticos são chamados de problemas (LEEUWEN, 2008, p.46). A Objetivação, por sua vez, consiste na referência metonímica de algo, pode ser por Espacialização, Autonomização de Enunciado, Instrumentalização e Somatização.

Exemplos:

Abstração

...atitudes infiltradas que visam constituir vandalismos.

...estão em plena sintonia com reivindicações expressas nas ruas,

Ouvir as vozes das ruas é dever de todos os poderes.

Objetivação

O Brasil acordou nesta terça-feira mais forte...

E o movimento precisa dialogar com o Congresso Nacional. 
é hora de o Parlamento saber escutar este pulsar das ruas.

Outra contribuição de van Leeuwen diz respeito à representação de ações sociais. Baseado no Sistema da Transitividade de Halliday, o autor investiga as ações além das representações. Segundo ele, os textos são cheios de reações. Explica que "conforme o poder dos atores sociais diminui, a quantidade de reações emotivas atribuídas a eles aumenta" (LEEUWEN, 2008, p.56). Faz distinção entre ação e reação. Segundo van Leeuwen, os processos materiais descreveriam a ação e os processos mentais a reação. Assim, teríamos, por exemplo, "imigrar" como ação e "preocupar-se" como reação. No entanto, esse não seria o único critério, pois podem ser expressas por grupos nominais e por orações descritivas (em vez de dizer "eles temiam”, diz-se eles estavam com medo"). Conclui que esse fenômeno sociosemântico é realizado congruentemente pelos processos mentais e metaforicamente por outras formas como as orações estáticas descritivas. Os tipos de processos mentais (afetivo, perceptivo, cognitivo) vão mostrar que tipos de reações os atores têm, se são reações racionais ou não, por exemplo.

Por meio da descrição do Sistema da Transitividade, ao observarmos a utilização de Processos Materiais e Mentais poderemos entender as ações e reações de deputados e dos manifestantes.

\subsection{Representação (Fairclough 2003)}

Fairclough lembra que os discursos não somente representam o mundo como ele é, mas criam também projeções, mundos imaginários que revelam como a realidade pode ser mudada. Podem ainda usar um mesmo termo de maneiras diferentes, por isso é necessário observar as relações semânticas para identificar tais diferenças.

Esse autor também destaca que textos que representam os mesmos aspectos do mundo dentro da mesma rede de práticas sociais se diferenciam quanto ao que escolhem destacar (2003, p. 127). Dessa maneira, num texto, um ator social pode ser referido como agente dominante e em outro discurso nem aparecer. 
Acerca da representação, Fairclough ressalta que aspectos do mundo físico e do mundo mental podem ser representados. O foco de sua análise, no entanto, são os aspectos sociais, especialmente os atores sociais. Lembra que é importante observar a agência, cuja escolha revela significados políticos e sociais (2003, p. 135). Além disso, trata da construção social do tempo e do espaço.

Assim como van Leeuwen (2008), ele investiga que elementos são incluídos e quais são excluídos nas representações. Diz que há formas concretas e abstratas de representar (2003, p. 138): a mais concreta envolve a representação de eventos sociais específicos, a mais abstrata a de práticas e estruturas sociais. Assim, o político pode escolher mencionar um determinado protesto ou falar genericamente sobre a capacidade que o povo tem de se unir para fazer reivindicações.

Outro ponto a ser observado é a relação polêmica ou dialógica presente nos discursos. Eles podem responder ou englobar partes de outros discursos. Dessa forma, um parlamentar ao chegar à tribuna para proferir um discurso, já ouviu a fala de seus pares, a repercussão do assunto na imprensa e, tudo isso vai se refletir em seu pronunciamento.

Fairclough (2003, p. 129) também trata os discursos como representantes de uma parte do mundo sob determinada perspectiva, por isso exorta-nos a identificar que área da vida social, que tema está sendo representado e, em seguida, identificar de que ângulo ou ponto de vista ocorre essa representação.

Finalmente, Fairclough considera que, ao representarmos um dado evento social, conectamos esse evento a outros, fazendo assim o que ele chama de recontextualização (2003, p. 139). Dessa forma, uma análise das manifestações ocorridas no Brasil em junho de 2013 pode conectá-la a outros movimentos de protesto ocorridos no mundo naquele período ou a movimentos que ocorreram no país em outras épocas.

\subsection{A Contribuição da ADC}

Dando continuidade à contribuição da Análise de Discurso Crítica (ADC) para este estudo, discorro um pouco sobre o que foi tratado por Chouliaraki e Fairclough (1999) 
a respeito do uso da ADC nos estudos sociais da modernidade tardia. Para eles, a ADC vem abordar as transformações que ocorrem nesse tempo que se dão principalmente na linguagem e no discurso, campos que não são contemplados por outras teorias sociais. (Chouliaraki \& Fairclough, 1999, p.4).

Segundo eles, é importante, porém, não reduzir a vida social ao discurso, pois ele é apenas um momento entre outros. Cada momento internaliza os outros. Assim, o discurso é prática material, uma forma de poder etc. (1999, p.6).

A ADC surge então como elemento de contribuição nas pesquisas de práticas sociais. Ela, além de trabalhar combinada a outros métodos, coloca em diálogo teorias sociais e teorias linguísticas. Dessa forma, a ADC é teoria e método ao mesmo tempo (1999, p. 16).

Consideramos que as práticas sociais são formas habituais de agir no mundo, elas constituem a vida social. As práticas são um ponto de conexão entre estruturas abstratas e seus mecanismos e eventos concretos, entre a "sociedade" e as pessoas vivendo suas vidas. Cada prática é constituída de momentos, que seriam os elementos da vida (tipo de linguagem usada, pessoas envolvidas etc.). O discurso é um desses momentos. As práticas estão entre as estruturas e os eventos, numa visão dialética considerando a ambiguidade do termo "prática”. (1999, p. 22).

Além disso, é preciso observar que cada prática integra uma rede de relações com outras práticas. Essas relações externas determinam sua constituição interna. Ocorre o que os autores chamam de articulação e internalização. Tais redes são mantidas pelas relações de poder. As relações de poder são relações de dominação, podendo ser econômica, de gênero ou de raça difundidas na sociedade. E toda prática social estaria firmada em redes de relações de poder (1999, p.24).

Eles trazem o conceito de Gramsci de hegemonia em que as relações de dominação não se dão por coerção, mas por consentimento, pela naturalização de práticas e relações entre práticas. Assim, tal conceito enfatiza a importância da ideologia para manutenção das relações de poder. (1999, p.24) 
Há também o caráter reflexivo das práticas: representações do que se faz como parte do que se faz (1999, p. 26). O discurso parlamentar aí é parte do acontecimento, da prática social. Ele é a resposta às manifestações ou a reflexão sobre os eventos. Pode atender uma reivindicação ou ser motivo para novos protestos no dia seguinte. Tem a ver com o que os autores chamam de reflexão construtiva das práticas sociais. Os deputados estão falando e ao mesmo tempo pensando sobre o que estão dizendo e o resultado daquilo que fazem ou deixam de fazer. Os autores nos levam, então, a refletir sobre o discurso como sendo parte de um todo que não pode ser ignorado. O texto não deve ser visto isoladamente, mas como algo que tem seu significado completado ao levarmos em consideração seu contexto.

Outras teorias sociais negligenciaram a linguagem. A ADC vem para corrigir esse erro. Corre o risco, no entanto, de resumir a vida social ao discurso. O discurso, por sua vez, inclui além da linguagem, comunicação não-verbal, imagens e outras semióticas.

Trazendo a definição dada por Smith (1990), eles lembram que o texto é analisado por sua participação nas relações sociais. Por meio dele, é possível compreender a organização social dessas relações. O texto seria então um meio de compreender os fenômenos sociais e não um fim em si mesmo.

Tratam também da importância de estudar a língua nas interações sociais e de se levar em conta que mesmo num texto escrito há diálogo, pois há sempre um interlocutor a quem nos dirigimos. Falam da situação das pessoas na modernidade tardia. Elas vivem pressionadas por questões ambientais, globalização, cuidados com o corpo. Os autores propõe, então, temas para estudo em ADC: globalização, reflexividade, ideologia, identidade, entre outros (p. 93). Curiosamente, ressaltam que a reflexividade iria na contramão da ideologia, uma vez que essa requer naturalização do discurso como forma de dominação. Em seu lugar surge a fragmentação, ou seja, a dificuldade da visão do todo. (1999, p.95).

Finalmente, tratam da importância da LSF para os estudos de ADC. A Linguística Sistêmico-Funcional é tida como a principal ferramenta para análise textual $(1999$, p. 139). Eles acreditam que essa relação teórica precisa ser expandida. 
Com relação à transdisciplinaridade da ADC, Chouliaraki e Fairclough lembram o seguinte:

"Vemos a ADC trazendo uma variedade de teorias ao diálogo, especialmente teorias sociais, por um lado, e teorias lingüísticas, por outro, de forma que a teoria da ADC é uma síntese mutante de outras teorias; não obstante, o que ela própria teoriza em particular é a mediação entre o social e o linguiístico a 'ordem do discurso', a estruturação social do hibridismo semiótico (interdiscursividade)" (1999, p.16).

Trata-se, deste modo, de uma transdisciplinaridade com um foco sobre a relação entre o mundo social e a linguagem.

\subsection{Abordagens teóricas - integração}

A Análise de Discurso Crítica (ADC) investiga o uso da linguagem com o propósito de desvelar as desigualdades construídas nas relações sociais. Para isso, requer uma teoria gramatical que relacione linguagem e contexto social a fim de explicar as diferenças entre os textos e relacioná- los aos contextos de cultura e de situação. (SILVA, 2010, p.62). Tal objetivo, alinha-se à teoria da Linguística Sistêmico-Funcional (LSF), que será utilizada nas análises do corpus desta pesquisa.

Além disso, Chouliaraki e Fairclough (1999), p. 16) sugerem que a ADC coloca teorias em diálogo, especialmente as teorias sociais e as linguísticas, dessa forma trabalhamos com o conceito de transdisciplinaridade, em que a lógica de uma disciplina é colocada para trabalhar junto a lógica de outra.

Na presente pesquisa, faremos a análise integrando as categorias de van Leeuwen (2008) a respeito da representação dos atores sociais; a Metafunção Ideacional, revelando os participantes, processos e circunstâncias, conforme o Sistema da Transitividade; além disso, será útil para observação se tais representações são concretas ou mais abstratas, conforme proposto por Fairclough (2003).

A Metafunção Interpessoal, por sua vez, pode revelar o posicionamento e comprometimento dos Deputados com aquilo que falam a respeito das manifestações. 
Considerando o que é dito por Fairclough (2012), encontraríamos na fala dos políticos os valores e interesses que os levam a tomar decisões.

Tanto Giddens (1991) quanto Castells (2013) tratam de confiança. Giddens lembra a necessidade que temos de confiar em sistemas que não dominamos, já Castells fala da confiança abalada em representantes do governo que levou a população às ruas. Vemos também que as aflições individuais que invadem a esfera pública, mencionadas por Bauman (2001), relacionam-se à falta de uma reivindicação única constatada por Castells em seu estudo sobre os protestos ao redor do mundo. 


\section{Capítulo 3}

\section{Metodologia}

O foco deste capítulo é a apresentação dos aspectos teórico-metodológicos utilizados nesta pesquisa. O capítulo metodológico é composto por oito seções. Na primeira (3.1), trato da pesquisa qualitativa. Na segunda seção (3.2), trago explicações acerca da pesquisa documental. Na terceira (3.3), revelo minhas questões de pesquisa. Já na quarta (3.4), faço uma descrição do corpus deste estudo. Explico como foi feita a análise dos dados na quinta seção (3.5). Apresento o arcabouço proposto por Chouliaraki e Fairclough (1999) na seção (3.6). Na sétima seção (3.7), falo do contexto de situação apresentado por Eggins (2004) e, finalmente, na oitava seção (3.8), encerro o capítulo fazendo algumas considerações.

\section{Introdução}

O uso de medidas múltiplas, mas independentes, é denominado como triangulação, que significa o uso de três pontos de referência para se verificar a localização de um objeto (TEIXEIRA, 2003, p. 189). Nesta pesquisa, utilizei uma triangulação teórica, quando submeti os discursos a diferentes formas de análise a fim de esclarecer o problema que motivou este estudo.

Primeiramente, foi feita uma revisão bibliográfica da teoria tanto da ADC quanto da LSF de forma a investigar o assunto da minha pesquisa sob diferentes perspectivas. Assim, analisarei a forma como o povo é representado nos discursos parlamentares por meio dos traços linguísticos identificáveis no Sistema da Transitividade e no Sistema de Modo. Além desses aspectos, a Teoria da Representação dos Atores Sociais proposta por van Leeuwen (2008) também trará luz para essa investigação. A ADC, por sua vez, vem contribuir com a utilização do arcabouço de Chouliaraki e Fairclough (1999), que propõe o estudo do problema social como algo que pode ser elucidado por meio da análise linguística. 


\section{1 - A Pesquisa Qualitativa}

A pesquisa qualitativa tem se tornado relevante para o estudo das relações sociais devido ao que Flick (2004, p.17) chama de "pluralização das esferas de vida". Com as mudanças sociais acontecendo rapidamente, os pesquisadores deparam-se cada vez mais com situações novas que requerem outros conhecimentos e novos métodos de estudos. Flick afirma também que, para que os resultados das ciências sociais sejam utilizados na vida cotidiana, suas investigações não se devem afastar dos problemas do dia-a-dia, como muitas vezes acontece quando os pesquisadores ficam presos a métodos de natureza quantitativa (FLICK, 2004, p.19).

Bauer e Gaskell (2002, p. 22) diferenciam a pesquisa quantitativa da pesquisa qualitativa. A primeira lida com números e estatísticas para elucidar os dados, já a segunda utiliza textos e a interpretação dos fenômenos sociais. Os autores defendem, no entanto, que não há quantificação sem qualificação, ou seja, os fatos sociais precisam ser interpretados antes que lhes seja atribuída uma frequência. Logo, uma pesquisa numérica deve considerar questões de interpretação. Com isso, temos que quantificação e qualificação não precisam andar separadas. Partindo desse argumento, este estudo, embora se constitua como pesquisa qualitativa, fará uso também de dados numéricos a serem interpretados à luz do aporte teórico apresentado no Capítulo 2 desta dissertação.

A respeito da seleção dos dados, Bauer e Gaskell (2002, p. 39) falam que toda pesquisa social precisa justificar que elementos serão investigados, descritos, analisados. Eles lembram que, na constituição do corpus, é preciso considerar a relevância, homogeneidade e sincronicidade (p.55). Observando tais aspectos em minha pesquisa, entendo que o assunto é relevante, afinal a população se mobilizou no período analisado para cobrar de seus representantes determinadas atitudes. Foi selecionado apenas um ponto de vista: o dos parlamentares. Segundo os autores deve haver apenas um foco temático. Os discursos selecionados, portanto, possuem como assunto principal as manifestações de junho de 2013. A homogeneidade está na escolha de discursos proferidos em Plenário por Deputados Federais. A sincronicidade foi considerada ao selecionar discursos do dia seguinte a uma grande manifestação (18/06/2013). 


\subsection{Pesquisa documental}

Trata-se de uma pesquisa documental com abordagem qualitativa. Por documento entendem-se todas as realizações produzidas pelo homem que se mostram como indícios de sua ação e que podem revelar suas ideias, opiniões e formas de atuar e viver (Bravo, 1991, apud Silva, Damaceno, Martins, Sobral \& Farias, 2009). É qualitativa, pois não enfoca a quantificação ou descrição dos dados, mas a importância das informações. Além disso, embora seja uma pesquisa de natureza qualitativa, houve um tratamento quantitativo dos dados com estatística de uso de processos, por exemplo.

O estudo de documentos consiste em dois momentos: a coleta e a análise do conteúdo (Silva et al., 2009). Na fase de coleta, ocorre uma pré-análise, ou seja, a adoção de critérios que levem a seleção dos documentos, no entanto, nessa fase ainda não há uma interpretação profunda do teor dos textos, ficando para a próxima fase essa tarefa. Nesta pesquisa, utilizei documentos que são de domínio público e ficam disponíveis no sítio da Câmara dos Deputados (www.camara.leg.br). A coleta se deu por meio de busca naquele sítio, usando como critério a expressão "manifestação coletiva" na indexação. Em seguida, separei os discursos por partido político e selecionei os excertos das falas dos líderes partidários ou, na falta desse, dos pronunciamentos de um representante de cada partido.

Já na fase da análise de conteúdo, é feita a descrição e interpretação das mensagens contidas nos textos a fim de responder à problemática que deu origem ao estudo. "A análise de conteúdo está balizada nos pressupostos de uma concepção crítica e dinâmica da linguagem que, por sua vez, é entendida como forma de expressão de representações sociais historicamente constituídas acerca da realidade social vivida por determinado grupo e expressas nos documentos por eles produzidos" (Silva et al., 2009). Segundo Teixeira (2003, p.191), a etapa de análise "é o processo de formação de sentido além dos dados". A descrição possibilita respostas e a análise, de forma mais ampla, liga essas respostas a teorias e conhecimentos anteriores. Nesse aspecto, pude, por meio das análises das Metafunções Ideacional e Interpessoal, além da taxonomia proposta por van Leeuwen (2008) e da análise do discurso apoiada por Fairclough (2003), desvendar os recursos linguísticos empregados pelos oradores para expressar a realidade, suas opiniões e 
pensamentos a respeito dos eventos ocorridos à época. O tratamento dos dados foi feito de forma a revelar a maneira como o povo foi representado naqueles discursos, por isso a observação de que termos foram usados para se referir ao povo, que lugar ocupavam na oração, que processos verbais estavam associados a eles e se foram excluídos ou incluídos nas falas possibilitou esclarecer essa problemática.

Os autores falam também da distinção entre unidades de contexto e unidades de registro. As primeiras dizem respeito aos elementos que ajudam a compreender o contexto em que está inserida a mensagem, enquanto as unidades de registro são obtidas com a decomposição da mensagem. Para ajudar a compreender o contexto neste estudo, observouse a data do pronunciamento e a que partido pertencia o orador, por exemplo.

Outra etapa da pesquisa envolve classificar os dados e colocá-los em categorias. Com base nos objetivos a serem alcançados, o pesquisador define as categorias. Os dados estudados nesta dissertação foram tabulados e classificados conforme as metafunções e taxonomia já mencionada. Teixeira (2003) aponta também a avaliação das generalizações obtidas com os dados como fase interessante na pesquisa.

Outro aspecto importante na pesquisa é a inferência, isto é, ver além daquilo que está escrito para chegar à interpretação (Silva et al., 2009). Eles concluem, citando Gomes (2007, p. 91, apud Silva et al., 2009): " chegamos a uma interpretação quando conseguimos realizar a síntese entre: as questões de pesquisa, os resultados obtidos a partir da análise do material coletado, as inferências realizadas e a perspectiva teórica adotada". A pesquisa documental é, pois, relevante não por responder definitivamente a um problema, mas porque proporciona melhor visão desse problema ou então hipóteses que conduzem a sua verificação por outros meios (Silva et al., 2009).

Ainda a respeito da pesquisa documental, vemos que uma de suas vantagens é eliminar a influência do pesquisador, pois não há interação desse com o autor do documento. O comportamento e reação do estudioso não são sentidos por aquele que produz a fala ou texto que será analisado. 
Silva, Almeida e Guindani (2009, p.9) falam da importância de termos informações sobre o autor do documento que estudamos "Não se pode pensar em interpretar um texto, sem ter previamente uma boa identidade da pessoa que se expressa, de seus interesses e dos motivos que a levaram a escrever". É necessário saber se o autor fala em nome de si próprio ou de um grupo. No caso dos discursos por mim analisados, os parlamentares estavam falando em nome de seus partidos políticos, logo, mais que uma opinião pessoal, eles expressaram a visão de seus colegas, de suas bancadas políticas. Portanto, possuir informações acerca do deputado que discursava ajudou-me a compreender sua posição e ler nas entrelinhas de seu pronunciamento.

\subsection{Questões de Pesquisa}

A formulação das questões de pesquisa é guiada pelo objetivo de esclarecer o que as análises irão revelar. Flick ressalta a importância de, mesmo tendo uma idéia clara do que se quer pesquisar, manter-se aberto a resultados que podem surpreender (FLICK 2004 p.63). Nesse aspecto, a grande frequência de uso pelos parlamentares dos processos mentais desiderativos me levou a criar uma seção para tratar disso e ver qual o significado de sua utilização nos discursos.

Portanto, a fim de alcançar o objetivo central desta dissertação, buscarei responder às seguintes questões de pesquisa.

a) Como o povo é representado nos discursos parlamentares sobre as manifestações? (Com que termos? Por meio de quais participantes?)

b) De que forma os parlamentares são representam a si mesmos nos discursos?

c) Há modalidade? Como o orador se compromete com aquilo que fala? 
d) Como é construída, discursivamente e linguisticamente, a posição do parlamentar nesse momento histórico? (Ele foi para as ruas, sua visão é somente de dentro do Congresso, ele apoia ou critica?).

e) Que atores sociais são excluídos nos discursos? Qual o significado dessas exclusões? Em que circunstâncias elas ocorrem?

\subsection{Descrição do Corpus}

Para a coleta dos dados, realizei uma busca no sítio da Câmara dos Deputados com a expressão "manifestação coletiva". Foram encontrados 74 discursos de 18 de junho 2013. Diante de um volume tão grande e da impossibilidade de análise de todos os textos, separei dezesseis discursos para análise. O critério utilizado foi a seleção dos discursos dos líderes, pois esses falaram em nome de seus respectivos partidos políticos. Temos assim, catorze partidos representados, além de um discurso do Líder do Governo na Câmara e um do Líder da Minoria. Onze partidos eram da base do governo e três da oposição.

Dos textos encontrados (os discursos na íntegra encontram- se em anexo a esta pesquisa), extraí excertos que tratassem das manifestações para serem analisados. A partir deles fiz uma consulta ao áudio dos discursos para conferir como de fato foram pronunciados pelos deputados, uma vez que essas falas passam por revisão até serem publicadas em versão final na página da Câmara. Dessa maneira, os excertos aqui analisados estão de acordo com o áudio dos discursos também disponível no sítio da CD.

A descrição e a análise dos dados serão feitas com base no Sistema da Transitividade, Metafunção Ideacional, combinada com a taxonomia da teoria da representação dos atores sociais de van Leeuwen (2008). Além disso, a Metafunção Interpessoal será utilizada para analisar o posicionamento e comprometimento dos oradores com aquilo que está sendo dito. Tendo em mente o que diz Gill (apud Bauer \& Gaskell, 2002, p.255): “Os analistas de discurso, ao mesmo tempo em que examinam a maneira como a linguagem é empregada, devem também estar sensíveis àquilo que não é dito - aos 
silêncios". Levando isso em consideração, serão observados os apagamentos de agente e de participantes nas falas dos parlamentares. Dessa maneira, será feita uma leitura cuidadosa.

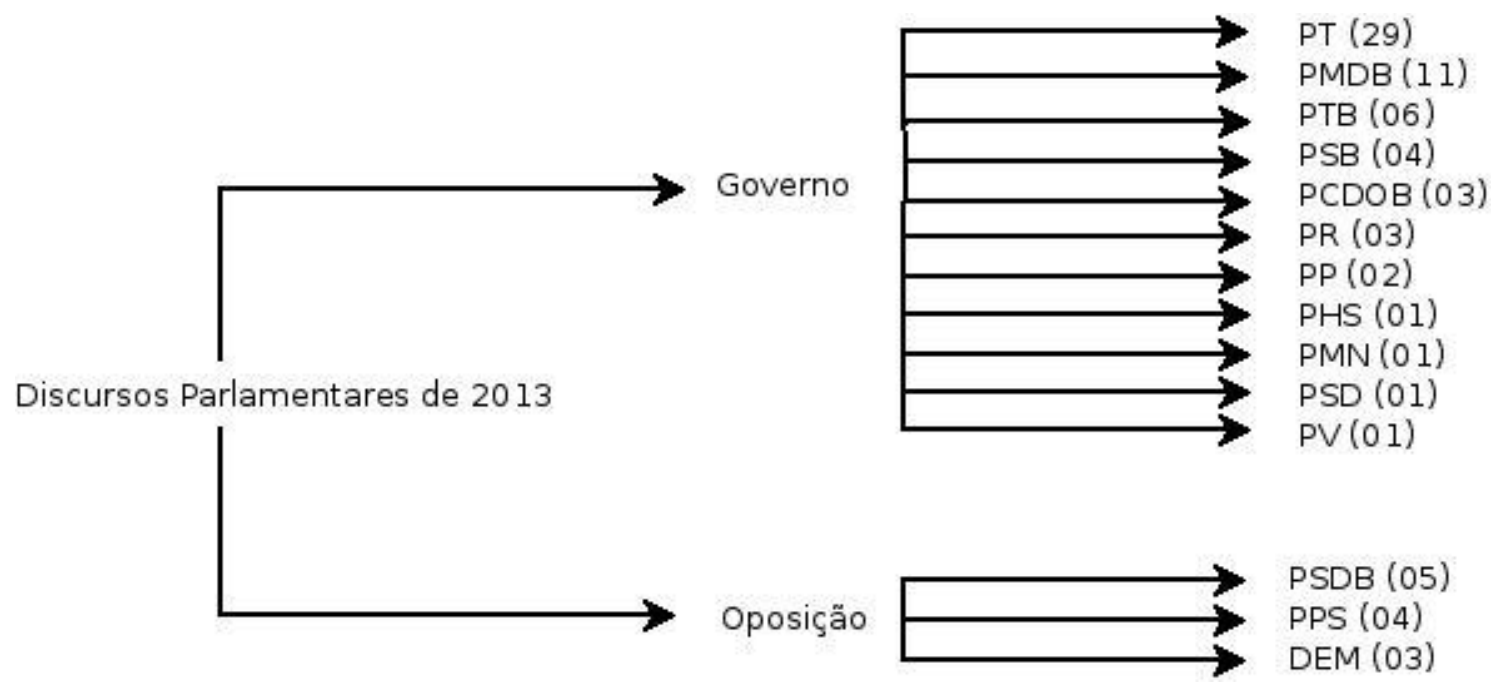

Figura 2 - Total de discursos por partido político sobre as manifestações em 18/06/2013

\subsection{1- Seleção dos excertos}

Com o auxílio da ferramenta AntConc, pude selecionar os excertos para análise. Todos os 74 discursos foram salvos em formato txt e submetidos ao programa. De tal modo, pude verificar que palavras ocorriam mais e depois disso, checar quais termos representavam o povo com maior frequência.

Os termos mais frequentes utilizados para representar o "povo" e o "governo" foram:

\begin{tabular}{|l|l|l|l|}
\hline Povo & Quantidade & Governo & Quantidade \\
\hline Brasil & 156 & Casa & 115 \\
\hline Manifestações & 154 & Nós & 113 \\
\hline Povo & 120 & Governo & 108 \\
\hline Sociedade & 101 & Deputados & 72 \\
\hline Movimento & 103 & Presidenta & 35 \\
\hline Ruas & 95 & Partidos & 23 \\
\hline
\end{tabular}




\begin{tabular}{|l|l|l|l|}
\hline Pessoas & 82 & & \\
\hline População & 78 & & \\
\hline
\end{tabular}

Quadro 3-Termos mais frequentes

A presença desses termos direcionou a escolha dos excertos.

\subsection{2 - AntConc}

O AntConc é um software de concordância gratuito criado por Laurence Anthony, doutor em Linguística Aplicada, que atua no desenvolvimento de tecnologias educacionais e linguística de corpus.

A Linguística de Corpus é um conjunto de métodos para estudo da linguagem. Constiste na coleta de um grande número de dados, corpus, que será analisado com o auxílio de ferramentas computacionais.

O AntConc é, pois, uma dessas ferramentas que possibilita trabalhar com muitos textos ao mesmo tempo. Entre outras funcionalidades, o programa permite verificar as palavras que ocorrem com maior frequência no texto (keyword). Além disso, exibe cada ocorrência da palavra e o contexto em que esses termos aparecem (Concordance). Dessa forma, é possível selecionar palavras e expressões e observar quantas vezes e de que modo (com quais antecedentes e subsequentes) elas ocorrem no discurso analisado. A coocorrência de determinadas palavras ou frases é chamada de Collocation. Outra funcionalidade do programa é a lista de frequência (Frequency list) quando uma lista de um determinado termo ou tipo de palavra é apresentada com a quantidade de ocorrências. 


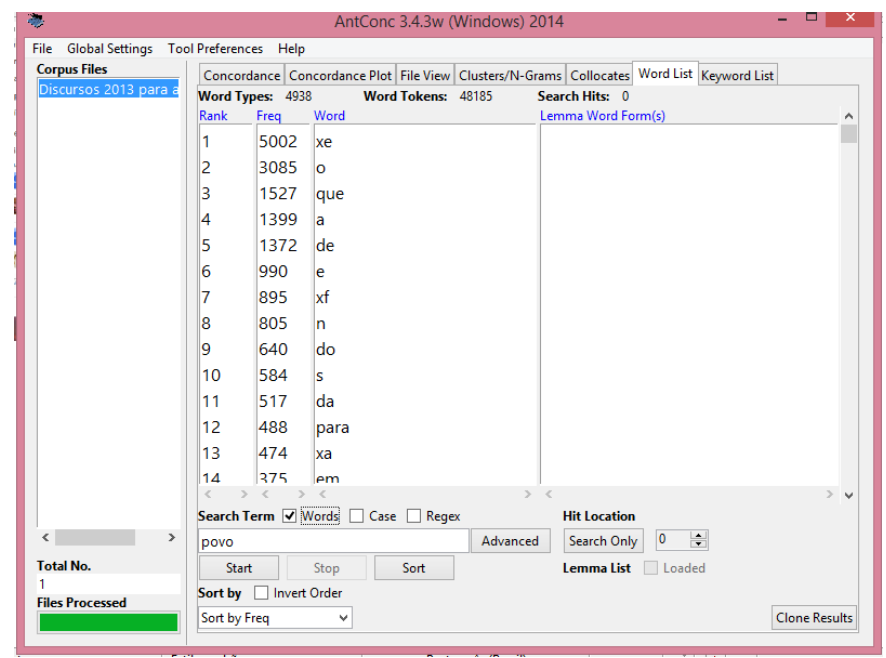

Figura 3 - Tela do AntConc (Lista de palavras).

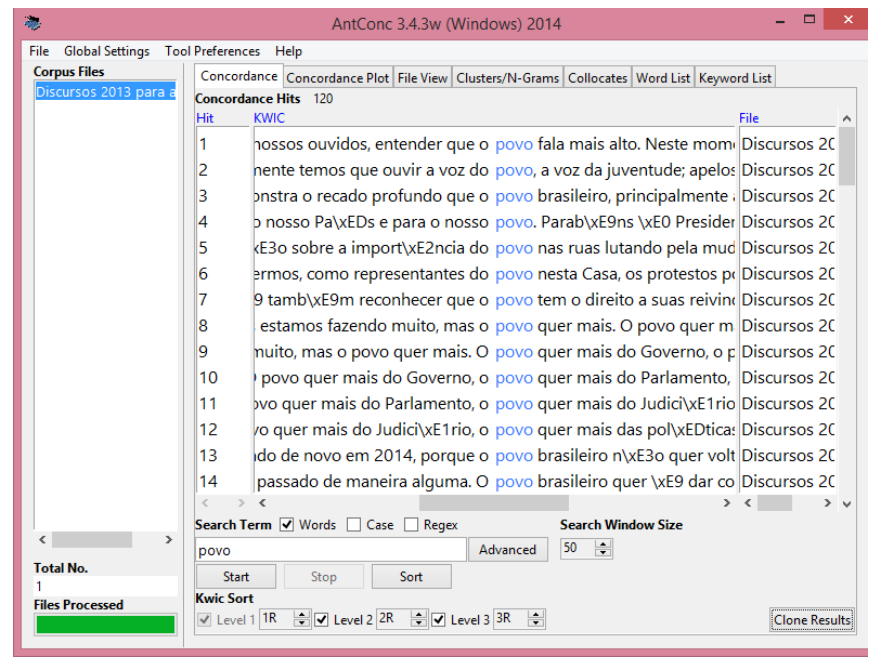

Figura 4 - Tela do AntConc (Busca pela palavra "POVO”).

\section{5 - Análises}

Selecionados os excertos, prossegui para as análises com base no Sistema da Transitividade, da Metafunção Interpessoal e da taxonomia proposta por van Leeuwen 
(2008). Tais escolhas das categorias teórico-analíticas justificam-se na medida em que Sistema da Transitividade permite-nos desvendar como a experiência foi representada por meio de Participantes, Processos e Circunstâncias. A Metafunção Interpessoal, por sua vez, revela o posicionamento do falante, e como ele estrutura a linguagem para interagir com seus ouvintes. Com isso, relações de poder entre emissor e receptor, bem como as de polidez, exigência, entre outras são compiladas pelos sistemas dessa metafunção. Finalmente, com a utilização da Representação dos Atores Sociais apresentada por van Leeuwen (2008), examinaremos que atores foram excluídos e quais foram incluídos nos discursos e de que maneira deram-se essas inclusões.

Unindo essas teorias, obtive tabelas como a mostrada abaixo:

\begin{tabular}{|c|c|c|c|c|}
\hline & $\begin{array}{l}\text { O Governo } \\
\text { brasileiro }\end{array}$ & tem que & ter & $\begin{array}{l}\text { autocrítica, } \\
\text { humildade de } \\
\text { entender que }\end{array}$ \\
\hline Transitividade & Possuidor & & Proc. Relacional & Possuído \\
\hline Modo & Sujeito & $\begin{array}{l}\text { Modulação } \\
\text { obrigação }\end{array}$ & $\begin{array}{l}\text { Finito }+ \\
\text { Predicador }\end{array}$ & Complemento \\
\hline Ator social & $\begin{array}{l}\text { Pessoalização - } \\
\text { Determinação - } \\
\text { Categorização - } \\
\text { Funcionalização }\end{array}$ & & & \\
\hline
\end{tabular}

Essas tabelas buscam a triangulação teórica para investigar os fênomenos linguísticos estudados nesta pesquisa, porquanto possibilitam a combinação e comparação dos rótulos atribuídos a cada parte da oração analisada.

\subsection{1- Compilação dos resultados}

Concluídas as análises de todos os excertos, era preciso verificar que resultados apontavam e que interpretação poderíamos obter dos discursos. 
Nesse momento, pude ver que atores sociais representavam o povo e quais representavam os governantes. A esse respeito, Fairclough (2003 p.136) fala que podemos olhar para os textos sob uma perspectiva representacional e observar que elementos foram incluídos e quais foram excluídos, além de checar entre aqueles incluídos quais aparecem em destaque.

Além disso, os dados também revelariam que tipos de processos e participantes do Sistema da Transitividade ocorreriam com maior frequência e qual o papel da modalidade na fala dos parlamentares.

Finalmente, pude comparar os resultados obtidos nas falas de Deputados da situação e da oposição para saber se havia diferença quanto ao tratamento dado aos manifestantes em seus pronunciamentos.

Do ponto de vista social, buscou-se verificar que resultados práticos foram alcançados pelos manifestantes no Congresso (a pauta foi alterada? Algum projeto solicitado foi posto em apreciação? Tal projeto foi rejeitado ou aprovado?).

\subsection{Arcabouço da ADC}

A presente pesquisa está ancorada na Análise de Discurso Crítica, por buscar desvelar as relações de poder presentes entre o parlamentar e o povo. Na medida, em que são eleitos como representantes do povo, os congressistas passam a decidir por eles. E essas deliberações acabam por afetar a vida dos cidadãos que nem sempre são ouvidos em seus anseios e solicitações. Utilizo, por isso, o arcabouço proposto por Chouliaraki e Fairclough (1999, p. 60) como forma de esquematizar a análise que está sendo feita.

\section{- Problema:}

Observar como o povo é representado nos discursos parlamentares sobre manifestações. Investigar as relações de poder presentes entre o parlamentar que pronuncia seu discurso na tribuna e o povo que protesta nas ruas.

\section{- Obstáculos a serem resolvidos:}

\section{- Análise da conjuntura:}


Os discursos ora analisados foram proferidos no dia 18/06/2013, um dia após uma grande manifestação em que houve tentativa de invasão do Congresso Nacional. O parlamentar, ao falar, dirige-se aos seus pares e principalmente à sociedade, que aguarda uma reposta do parlamento. Para compreender esse fenômeno linguístico-discursivo foi importante observar a contextualização social, por isso apresentei no capítulo 1 estudo sobre os movimentos sociais que ocorreram na época, informações sobre o papel do deputado federal e reflexões a respeito de confiança e poder.

- Análise da prática em foco (em que o discurso é um momento)

O discurso parlamentar revela o pensamento do Deputado como também do seu partido (quando ele fala como líder). É, também, uma resposta aos seus eleitores e reflete a maneira como o Poder Legislativo se comporta diante do clamor da população. Além disso, tem poder de decisão, poder de convencer seus pares a rejeitar ou aprovar uma proposição. Como exemplo, uma das reivindicações populares em 2013 era pela rejeição da PEC 37, que retirava o poder de investigação do Ministério Público. Tal proposta foi colocada em votação poucos dias após os protestos nas ruas e foi rejeitada.

\section{- Análise do Discurso:}

- Análise estrutural: a ordem do discurso (o discurso é transformativo e reprodutivo?)

- Análise interacional:

- Análise interdiscursiva (resposta de um deputado para outro)

- Análise linguística e semiótica: uso da LSF e das classificações dos atores sociais de van Leeuwen para ver como o povo foi representado nos discursos. Os quadros com as descrições dessas análises constam dos anexos desta pesquisa. E, no capítulo 4, apresentarei que interpretações obtive a partir dessas análises linguísticas. 


\section{3) Função do problema na prática}

Desvelar a forma como o povo é representado na fala dos congressistas pode trazer uma consciência do comportamento e intenções desses mandatários em relação ao que propõem e votam, uma vez que suas falas demonstram suas prioridades e os valores que baseiam suas decisões no parlamento.

\section{4) Possíveis formas de vencer os obstáculos}

Realizar análise linguística e semiótica dos discursos selecionados a fim de perceber que maneira o povo foi representado.

\section{5) Reflexões sobre a análise}

Os resultados da pesquisa devem gerar uma consciência crítica no cidadão que assiste ao seu Deputado discursar e votar nas sessões legislativas. É necessário que a população fiscalize os debates e atos que têm lugar no Congresso Nacional e não se deixem iludir por promessas, mas acompanhem se as palavras vêm acompanhadas de ações.

\section{7 - Contexto de Situação}

Eggins (2004) fala da importância do contexto para interpretação de textos. Ela afirma que, sendo textos do dia-a-dia ou obras literárias, há sempre pontos de indeterminação no que lemos, no entanto, buscamos diminuir esses graus de indeterminação em nossos textos práticos. A autora sugere que, muitas vezes, buscamos o contexto fora do texto, mas que outras vezes ele está dentro do próprio texto (2004, p.87). Assim, uma forma de descobrir esse contexto seria perguntar "quem participou da produção do texto, sobre o que trata o texto e qual o papel da linguagem no evento" (2004, p.88).

Além disso, citando os estudos de Malinovisky, Eggins (2004, p. 88) aponta que a linguagem é usada com um propósito determinado, é um recurso funcional. Três aspectos são propostos para análise do corpus desta pesquisa, levando-se em conta a ligação entre a organização da língua e o contexto: campo, modo e relações.

- Campo: a linguagem está sendo usada para falar de quê 
- Modo: que papel a linguagem está desempenhando na interação

- Relações: as relações entre os participantes

Neste estudo, Campo refere-se às manifestações populares; Modo diz respeito ao discurso oral proferido no plenário da Câmara dos Deputados e, Relações reporta-se ao Deputado que fala aos seus pares e ao público que assiste a ele das galerias do plenário e pela TV Câmara.

O corpus desta pesquisa são discursos orais pronunciados diante de outros parlamentares, com interação visual e auditiva direta, e também dirigidos ao público que os vê pela televisão, nesse caso sem um feedback imediato. Essas falas, porém, transformamse em textos escritos que são publicados na página da Câmara na internet e são lidos posteriormente pelo público. Mistura aspectos de linguagem oral e escrita, uma vez que podem ter sido improvisados, mas também podem ter sido escritos anteriormente para serem lidos. Além disso, não há uma resposta imediata, já que o parlamentar não deve ser interrompido durante sua fala. Apesar de inicialmente selecionar os discursos pela página da Câmara, em sua forma escrita, ao analisar os excertos em que o povo é mencionado, busquei a fala do deputado no áudio, encontrando assim, características mencionadas por Eggins (2004, p. 93) como sendo da fala oral, a saber: fenômenos de espontaneidade (hesitação, interrupção, sentenças incompletas, repetições).

Eggins (2004, p.94) ressalta que, quando mudamos de linguagem oral para a escrita, geralmente, usamos nominalizações. Com isso, ao nominalizarmos ações, organizamos o texto em termos de ideias, razões e causas. Os atores transformam-se em portadores, os processos de ação viram nomes e processos materiais convertem-se em relacionais.

A autora compara a linguagem oral à escrita (p.98) e conclui que na fala tendemos a ligar vários períodos gerando sentenças longas, porém na escrita isso tende a não acontecer. A propósito, no discurso do Deputado Colbert Martins, foi possível observar um exemplo de período longo típico da linguagem oral:

"Aqueles radicais, os que passarem do limite, nós sabemos, têm de ser contidos, mas a grande maioria das pessoas que estão nas ruas têm um 
motivo, Sr. Presidente, e nós não sabemos dar resposta adequada a elas, não sabemos utilizar a sua linguagem direta."

Quanto às Relações do discurso, convém observar três aspectos: poder, proximidade e envolvimento afetivo. Situações formais diferem das informais nesses aspectos. O uso da modulação e modalização também difere: na fala informal são usadas para expressar probabilidade e opinião, respectivamente; já na fala formal, para deferência e sugestão. É importante também examinar os vocativos (uso de pronome formal, diminutivo, primeiro nome etc.), o uso ou não de gírias ou de linguagem informal.

Finalmente, quanto ao Campo pode haver diferenciação quanto à profundidade com que o tema é tratado no texto, isto é, se é dirigido a especialista no assunto ou ao público em geral. Isso estará refletido no vocabulário escolhido, por exemplo.

A relação entre esses três aspectos do texto e as três metafunções nos mostra que o Campo é manifestado pelos significados ideacionais, o Modo pelos significados textuais e as Relações pela Metafunção Interpessoal. O registro (contexto de situação) reflete a diversidade metafuncional no nível da linguagem materializada pela léxico-gramática. As escolhas no nível de cultura (gênero) refletir-se-ão nas escolhas no nível situacional (registro), que, por sua vez, se materializam pela linguagem.

O quadro a seguir mostra o diálogo entre contexto, semântica e escolhas léxicogramaticais. Ele expõe as metafunções ocorrendo simultaneamente nos discursos e revelando cada uma um tipo de significado. Dessa maneira, vemos que recursos linguísticos revelam representação do que acontece, interação entre participantes e trazem coesão ao texto. 


\begin{tabular}{|c|c|c|}
\hline $\begin{array}{l}\text { CONTEXTO } \\
\text { SITUACIONAL }\end{array}$ & SEMÃNTICA & LÉXICO-GRAMÁTICA \\
\hline $\begin{array}{l}\text { Traço do contesxto } \\
\text { Estruturas semióticas da } \\
\text { situaçăo }\end{array}$ & $\begin{array}{l}\text { Funçầo da linguagem } \\
\text { Componentes funcionais da } \\
\text { semântica }\end{array}$ & $\begin{array}{l}\text { Nivel da oraçăo } \\
\text { Escolhas léxico-gramaticais }\end{array}$ \\
\hline $\begin{array}{l}\text { Campo do discurso } \\
\text { (o que está acontecendo) } \\
\text { a atividade social }\end{array}$ & $\begin{array}{l}\text { Significados ideacionais } \\
\text { Conteúdo da experiência } \\
\text { (recursos para a construçăo } \\
\text { do conteúdo) }\end{array}$ & $\begin{array}{l}\text { Estruturas de transitividade } \\
\text { Oraçăo como representaçăo } \\
\text { (processos, participantes, } \\
\text { circunståncias) }\end{array}$ \\
\hline $\begin{array}{l}\text { Relações interpessoais } \\
\text { (quem participa e papéis } \\
\text { sociais) } \\
\text { A relaçåo entre os } \\
\text { participantes envolvidos } \\
\text { Como os participantes săo } \\
\text { representados }\end{array}$ & $\begin{array}{l}\text { Significados interpessoais } \\
\text { Interaçăo pessoal } \\
\text { (recursos para a interaçăo) }\end{array}$ & 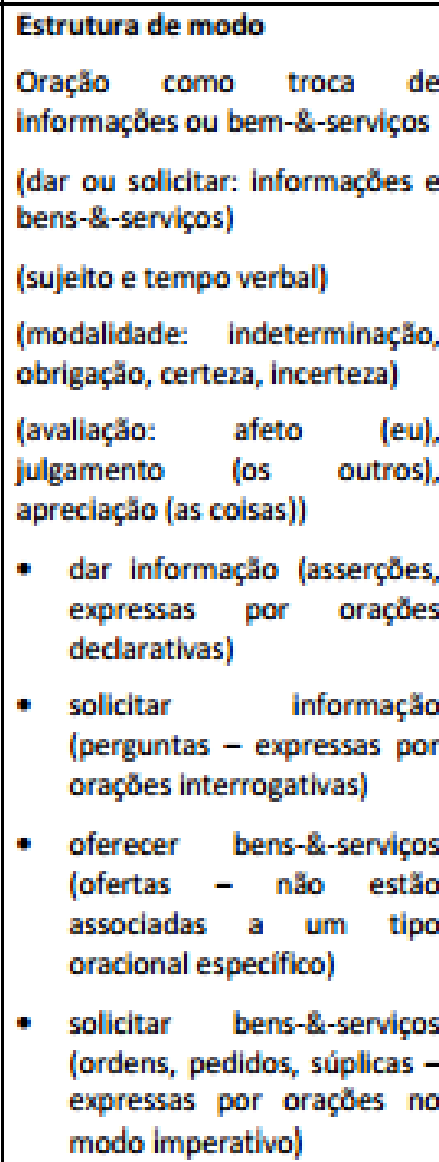 \\
\hline $\begin{array}{l}\text { Modo do discurso } \\
\text { (o papel da linguagem) } \\
\text { Canal simbólico ou retórico }\end{array}$ & $\begin{array}{l}\text { Significados textuais } \\
\text { Estrutura textual } \\
\text { (recursos para a organizaçăo } \\
\text { do texto) }\end{array}$ & $\begin{array}{l}\text { Estruturas temáticas } \\
\text { Oraçăo como mensagem } \\
\text { (tema e rema) } \\
\text { (sistema de coesão) }\end{array}$ \\
\hline
\end{tabular}

Quadro 4- Contexto situacional, semântica e léxico-gramática

Fonte: slide da aula de Linguística Sistêmico -Funcional,.2013. 


\subsection{Algumas considerações}

Nesse capítulo, trouxe uma explanação sobre os métodos de pesquisa por mim utilizados. Além disso, expus minhas questões de pesquisa e descrevi a seleção do corpus deste estudo. Demonstrei, também, um pouco do funcionamento da ferramenta computacional por mim utilizada e expliquei a forma como os dados foram analisados à luz do aporte teórico que embasa esta dissertação. O diálogo entre a ADC, a LSF e a classificação dos atores sociais proporcionou a triangulação teórica necessária para a compreensão do fenômeno linguístico aqui estudado.

Apresento no próximo capítulo a análise linguístico-discursiva dos excertos selecionados. 


\section{Capítulo 4}

\section{Análises}

Neste capítulo, exponho as análises feitas com base na descrição do Sistema da Transividade, do Sistema de Modo e da taxionomia proposta por Theo van Leeuwen (2008). As tabelas com a descrição completa constam dos Anexos desta dissertação. O capítulo está dividido em cinco seções. Na primeira (4.1), falo da Modalidade presente nos discursos parlamentares, que revelam o grau de comprometimento do parlamentar com aquilo que ele fala. Na seção 4.2, analiso a função do verbo "querer" nos pronunciamentos. Já na seção 4.3, discorro sobre os processos verbais que ocorrem com maior frequência nos excertos analisados e qual significado eles trazem. Em seguida, trato da representação com base em Fairclough (2003) e conforme a proposta de van Leeuwen (2008), na seção 4.4. Na seção 4.5, apresento a análise de cada discurso, buscando responder às questões de pesquisa expostas no Capítulo 3. Por último, na seção 4.6, trago resultados e discussão do que foi analisado.

\subsection{Modalidade}

Tendo em mente o propósito de interação da linguagem que, de acordo com Thompson (2004, p. 45) tem o objetivo de influenciar atitudes, trazer um novo conhecimento, solicitar informações e explicar nosso comportamento, sondamos os discursos parlamentares com vistas a encontrar marcas da Metafunção Interpessoal em suas falas.

Sabendo que o uso da modalidade é fundamental para conhecermos o posicionamento do falante, busquei nesses sinais deixados pelos autores em seus discursos desvendar sua atitude em relação aos movimentos de protesto.

A modalidade manifesta-se de diversas formas, entre elas encontramos o uso de:

- Verbo auxiliar modal: deve, pode

- Verbo indicador de opinião, crença ou saber: acho, acredito.

- Advérbio: provavelmente, obrigatoriamente, possivelmente, talvez. 
- Adjetivo em posição predicativa: É impossível, é preciso, vai ser necessário.

- Substantivo: esta é a minha opinião, tenho a impressão.

- Tempo verbal: ficaria, talvez tenha sido

Necessário e possível são graus relacionados à crença do falante na verdade da proposição, já obrigatório e permitido são graus ligados ao modo como um ato se apresenta social e legalmente. (NEVES, 2006, p. 164)

Examinando os excertos, percebi que os oradores utilizam a modalidade diversas vezes e isso me chamou a atenção para investigar como eles se comprometiam ou não com aquilo que estavam dizendo da tribuna do Parlamento.

Em alguns casos, vemos os parlamentares expressando sua obrigação de agir, no entanto, isso é colocado de diferentes maneiras. Quando Alice Portugal (PC do B) diz que "É preciso, portanto, saudar as manifestações espontâneas e autênticas", a expressão em negrito minimiza a participação de quem fala.

Arnaldo Jordy inclui o parlamento de forma impessoal: Acho que esta Casa, esta Câmara dos Deputados precisa imediatamente associar-se ao povo brasileiro nessas reclamações lícitas que ele está levando às ruas. O modalizador acho, no início, torna a afirmação menos firme, ao selecioná-lo o parlamentar busca enfraquecer o comprometimento com o que é dito.

O mesmo Deputado em outro momento, assim como outros parlamentares, optou pelo verbo flexionado no plural, uma maneira de incluírem a si e a seus pares, visando compartilhar o comprometimento com os outros. Tal recorrência também modaliza o discurso:

...precisamos também estabelecer uma agenda mínima. [7] ${ }^{1}$

Nós precisamos ouvir esta sociedade, organizada ou não, ela precisa ser ouvida. [9]

Sem polemizar, quero só levantar que nós precisamos ter muito cuidado em relação a isso. [11]

1 Os discursos integrantes do corpus desta pesquisa foram ordenados numericamente entre colchetes. Os textos completos encontram-se em anexo. 
Precisamos ouvir o povo [13]

Num mesmo período, podemos encontrar vários modalizadores, como, por exemplo, no discurso de Beto Albuquerque (PSB):

Eu preciso, em nome do Partido Socialista Brasileiro, também expressar preocupações e convicções com relação ao movimento legítimo que faz com que as ruas, as avenidas das cidades brasileiras comecem a falar, porque, talvez, não estejam sendo ouvidas onde devam ser ouvidas.

Nesse caso, Eu preciso e devam expressam obrigação, enquanto talvez demonstra imprecisão.

A esse respeito, Neves (2006, p.174) diferencia obrigação moral de obrigação material. A primeira viria da consciência do sujeito, enquanto a segunda de circunstâncias externas. Os exemplos dados acima representam obrigação moral.

Além do verbo "dever" e "precisar" para exprimir esse sentido de obrigação, os parlamentares utilizaram também o verbo "caber": "cabe a nós como Parlamentares percebê-lo" e a expressão tem que ou temos que, conforme ilustram os próximos exemplos.

Temos que ver os empresários que corrompem os corruptos. [11]

Então, nós temos que somar as vozes da rua com as vozes desta Casa[11]

Nós temos que construir esse Brasil e é esse Brasil, é essa nação que o povo espera de nós. [13]

Nós temos que perguntar a essa sociedade, através do plebiscito, o que ela quer fazer, dentro dos temas que nós temos que discutir. [4]

O Governo brasileiro tem que ter autocrítica [16]

E esta Casa tem que construir uma outra agenda [3]

A gente tem que ouvir a voz do povo [5]

... porque tem alguém que tem que pagar essa conta [11]

A modalidade permite aferir o grau de certeza com que o político se expressa. Por meio de expressões como sem dúvida, com certeza, parece e talvez, discernimos o comprometimento do orador com o que é dito. 
... isso, sem dúvida nenhuma, é o que a sociedade tem nos cobrado. [14]

...este é um movimento, sem dúvida, de indignação [8]

Mas, com toda a certeza, já antecipadamente dava para se dizer... [14]

Eu quero deixar aqui esta constatação e dizer que, com toda a certeza, essa mobilização das ruas deve ser entendida como uma manifestação de insatisfação. [14]

Ressalte-se que o excesso de modalização na fala do Deputado Eduardo Sciarra, [14], demonstra falta de assertividade, afinal "quanto mais dizemos que algo é certo, menos certo isso se torna" (Eggins, 2004, p. 175). As falas dos Deputados Anthony Garotinho e José Humberto, por sua vez, já vêm com as marcas típicas da imprecisão.

A sociedade parece que quer dar um passo adiante. [10]

A sociedade parece que está dizendo que quer ir para a democracia participativa. [10]

O que talvez a gente não esperasse ou a maioria não esperasse é que a força dessas manifestações talvez tenha assustado a Nação brasileira, e talvez, sobretudo a classe política. [12].

Os oradores fizeram uso, ainda, de modalizadores atitudinais:

Infelizmente, o que nós fazemos e o que temos feito não mais atende ao que essa sociedade quer. [4]

Primeiro, isso é um movimento nitidamente da classe média brasileira. [6]

Quem vive o dia a dia do povo percebe claramente a distância entre a realidade da propaganda, entre a realidade do discurso e a realidade do povo. [5]

Notamos também que alguns advérbios são usados com valor de polaridade positiva: O Governo brasileiro não conseguiu ter rumo, não conseguiu ter um projeto onde efetivamente melhore a vida da população [16]. Contudo, em dois momentos tivemos essa polaridade bem marcada nos discursos de dois parlamentares da base do governo:

Queremos sim fazer uma pauta consonante com a voz das ruas [1]

...a pauta que está posta para este Parlamento é ouvir sim aquilo que a sociedade está colocando. [2]

A polaridade negativa é um recurso linguístico bastante presente nos textos analisados. Muitas vezes, a negação vem refutar algo que foi afirmado anteriormente por alguém, como nos excertos a seguir: 
Não é um movimento contra a Presidenta Dilma. [3]

Nós do PT não nos sentimos intimidados com nenhuma manifestação. [3]

Não é susto o que a população está vivendo, é impaciência, indignação pela irresponsabilidade do Governo. [16]

Esse movimento da rua não tem proprietário. [16]

A negação também é útil para que o orador afirme coisas e ao mesmo tempo as censure (LINHARES, 2012, p.30), ou ainda, com o sentido de proibição ("não podemos").

Tivemos a oportunidade de avançar, de aproximar o Parlamento do povo brasileiro, de fazer partidos programáticos que pudessem representar correntes de pensamento nacional, e não o fizemos. [6]

Srs., se continuarmos achando que esses movimentos são contra o Governo do Estado A ou B ou contra o Governo Federal, nós vamos estar colocando uma venda em nossos olhos e não estaremos a perceber que a indignação é generalizada e estamos todos na vala comum. [8]

Eles não querem ser sardinha dentro de ônibus. [9]

A população não se sente representada e nós aqui temos dificuldade de fazer valer os nossos mandatos. [12]

O Governo brasileiro não conseguiu ter rumo, não conseguiu ter um projeto onde efetivamente melhore a vida da população. [16]

Mas a sociedade não esquece. [4]

Nós não vamos ter o respeito de nós mesmos, desta Casa, não vamos ter o respeito do povo brasileiro se nós acharmos que isso é só uma lufada de liberdade. [4]

A minha defesa se estende a outros poderes constituídos de que não podemos agir como se fôssemos os donos da verdade... [8]

\subsection{O verbo querer nos discursos}

Ao examinar os excertos, encontrei em várias falas o uso do verbo querer não apenas com a função de processo mental desiderativo, mas compondo locução verbal com o objetivo de enfraquecer ou atenuar o que estava sendo afirmado. Dessa maneira, fala-se "Quero dizer" em lugar de digo e, "Queremos sim fazer" em vez de faremos (Discurso da 
Dep. Alice Portugal). Nos dois casos, a oradora fala de um modo menos direto e, no segundo exemplo, demonstra apenas vontade e não compromisso. Revela um grau de inclinação não muito alto. O objetivo seria comprometer-se menos com o que é afirmado. Com o mesmo propósito, encontramos locuções no pretérito imperfeito no discurso do Deputado Eurico Júnior: "Queria também parabenizar os manifestantes", "Queria registrar isso".

Deparei-me também com essas construções na fala do Deputado André Vargas: "quero só avisar" "quero só levantar". Nessas ocorrências, o verbo querer vem ainda acrescido do advérbio "só", que tem valor restritivo e torna menos asseverativa a afirmação. O parlamentar em questão manifesta-se depois do discurso de seu colega para contestá-lo e, dessa forma, ele o faz com menos dureza.

Querer também aparece desempenhando papel desiderativo. Nessas passagens, o experienciador é o povo na maioria das vezes, como vemos em: "É a juventude do Brasil, que agora quer construir uma outra agenda", "o que temos feito não mais atende ao que essa sociedade quer", "É evidente que o povo quer sempre mais”, "O povo quer regularidade no transporte", "A sociedade parece que quer dar um passo adiante" e "Este é um movimento que quer ser ouvido”. Da mesma forma, ocorre com a presença da polaridade negativa em: "Eles não querem ser sardinha dentro de ônibus", "Eles não querem ser assaltados dentro de ônibus".

\subsection{Processos predominantes}

Tendo em vista que o objetivo desta pesquisa é investigar a representação do povo nos discursos parlamentares, o estudo da Metafunção Ideacional, especialmente do Sistema da Transitividade foi útil ao revelar que tipos de processos verbais foram escolhidos pelos oradores. Na tabela a seguir, apresento os processos predominantes em cada discurso e seu significado.

\begin{tabular}{|l|l|r|r|r|r|r|r|}
\hline & Deputado & Material & Mental & Relacional & Verbal & Existencial & Comportamental \\
\hline \multirow{5}{*}{ Governo } & Alice Portugal & 3 & 2 & 1 & 4 & 0 & \\
\cline { 2 - 8 } & Henrique Fontana & 0 & 2 & 2 & 1 & 0 & \\
\cline { 2 - 8 } & José Guimarães & 3 & 2 & 9 & 2 & 0 & \\
\cline { 2 - 8 } & Mário Heringer & 3 & 5 & 6 & 3 & 0 & \\
\hline
\end{tabular}




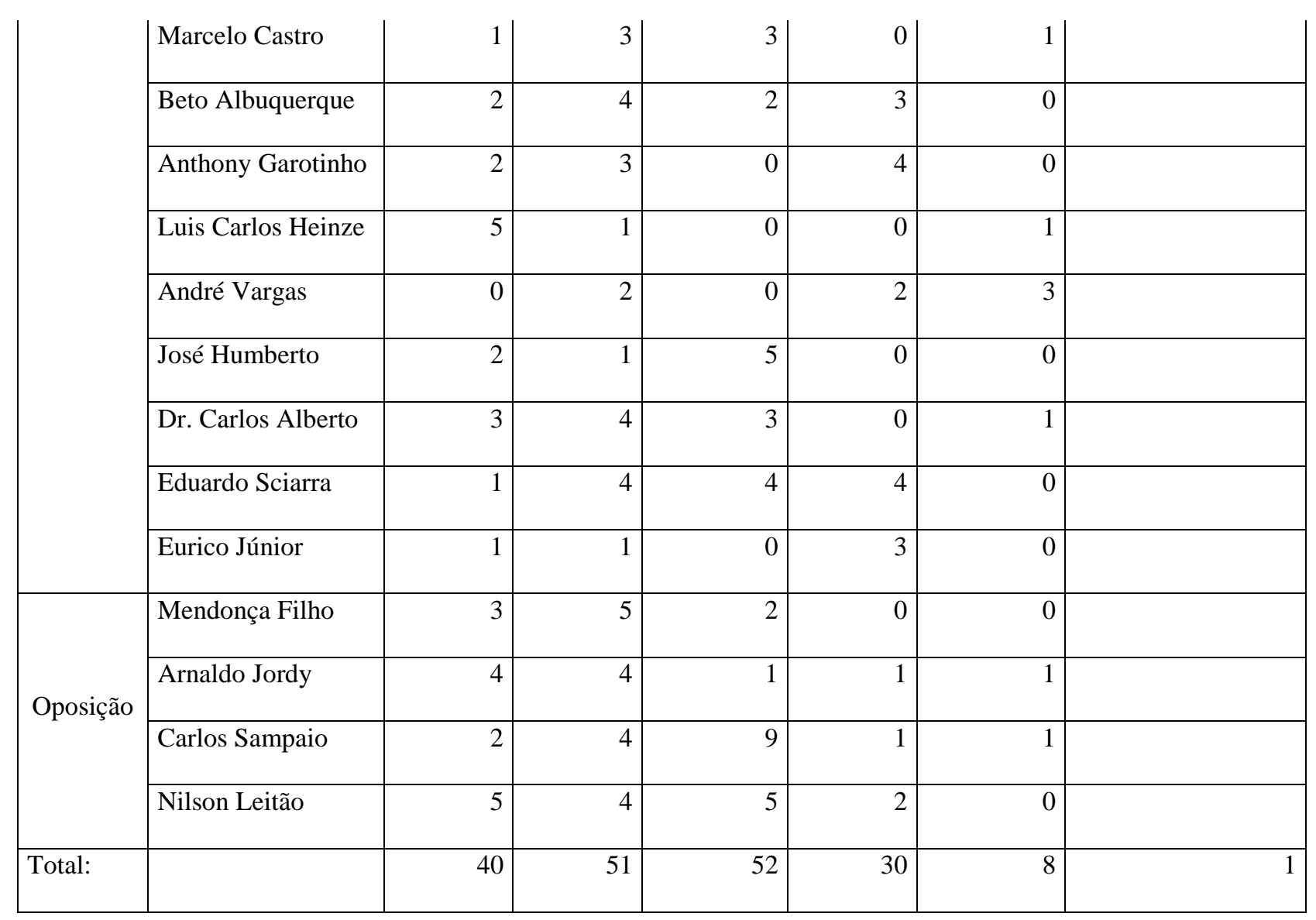

Quadro 5- Processos predominantes

Os processos podem representar a experiência de seis maneiras diferentes, são: materiais, mentais, relacionais, verbais, comportamentais e existenciais. Processos materiais são aqueles do fazer e acontecer, eles tratam de experiências exteriores. Processos mentais, diferentemente, tratam de experiências interiores e estão ligados às emoções e sentimentos. Os comportamentais são processos do comportamento tipicamente humano como suspirar, sonhar, tossir. Os verbais, por sua vez, são os processos de dizer; eles podem designar atividades (elogiar, criticar, insultar) ou semiose (prometer, ameaçar, persuadir, implorar). Os existenciais, por fim, representam algo que existe, seu verbo típico é "haver" e não apresentam sujeito.

Com base nessas informações, observamos que nos excertos da Deputada Alice Portugal há predominância de processos verbais e materiais. No caso dos verbais, o dizente era ela que "saúda", "parabeniza" e "repudia". Quanto aos materiais, com eles ela 
representou a ação das manifestações que "se espalharam" e "ganharam contornos difusos" e o desejo de o governo agir "queremos sim fazer uma pauta..".

Já o Deputado Henrique Fontana, usou a mesma quantidade de processos mentais e relacionais. O primeiro tipo demonstra a reflexão por parte do governo e o querer dos manifestantes ("Nosso governo entende os movimentos" e "os mais jovens querem uma saúde melhor"), enquanto o segundo caracteriza a pauta e a própria fala do orador. (“ $a$ minha frase está em sintonia com a nossa Presidenta” e "a pauta que está posta é ouvir sim aquilo que a sociedade está colocando”.

No discurso do Deputado José Guimarães, predominaram os processos relacionais. Ele buscou na sua fala, principalmente, caracterizar e definir os movimentos populares: “ $A$ manifestação aqui foi pacífica e democrática", "O povo na rua é nossa história”, "As manifestações são legítimas”.

$\mathrm{Na}$ fala do parlamentar Mário Heringer, prevaleceram os processos mentais e relacionais. Com os mentais ele falou do desejo de seu partido de ouvir a população e com os relacionais definiu o momento vivido no Brasil. ("O PDT quer colocar sua posição de ouvir a sociedade”, “O momento, Sr. Presidente, Srs. Deputados, é de ouvir essa sociedade, e uma maneira de ouvir essa sociedade é uma maneira constitucional".

Por semelhante modo, Marcelo Castro também fez uso mais vezes dos processos relacionais e dos mentais. Primeiro, buscou definir os protestos como sendo da classe média ("isso é um movimento nitidamente da classe média brasileira") e depois demonstrou a perplexidade por parte dos governantes diante das manifestações ("Quem de nós, verdadeiramente, supunha, pensava, acreditava que pudesse haver no Brasil tamanha insatisfação?").

O Deputado Beto Albuquerque priorizou os processos verbais e mentais. Com os verbais, ele colocou como dizente tanto ele mesmo quanto os manifestantes ("Eu preciso, em nome do Partido Socialista Brasileiro, também expressar preocupações e convicções”, “É a voz das ruas que está pedindo para ser ouvida."). Usando os processos mentais, ele 
expressou principalmente as aspirações do povo ("O povo quer regularidade no transporte", "Eles não querem ser sardinha dentro de ônibus").

Assim, como na fala de Beto Albuquerque, no discurso do Deputado Anthony Garotinho, encontramos mais processos mentais e verbais. Relata o sentimento e a fala do povo: "A sociedade parece que quer dar um passo adiante", "Ontem o povo dizia: Fora, Rede Globo”.

O Deputado Luis Carlos Heinze usou mais processos materiais, principalmente para representar ações que ele considerava que o governo deveria tomar ("Nós vamos nos juntar, vamos nos somar às pessoas de bem contra a corrupção").

A fala do Deputado André Vargas aparece como um complemento à do Deputado Luis Carlos Heinze, ele presidia a Mesa naquela sessão e por isso, antes de passar a palavra a outro orador, respondeu a Heinze. Em sua fala prevalecem os processos existenciais ("Houve manifestação contra a Rede Globo, houve manifestação a favor dos indígenas, há o debate sobre a questão dos direitos humanos.").

O Deputado José Humberto prioriza os processos relacionais. Ele usa processos relacionais possessivos para falar de sua dificuldade de lidar com a cobrança do povo ("nós aqui temos dificuldade de fazer valer os nossos mandatos", "Tenho tido dificuldade de explicar à população que me elegeu tudo aquilo que é nossa atribuição e nossa função").

Dr. Carlos Alberto caracteriza as manifestações por meio de processo relacional "As manifestações são justas e democráticas", fala da forma como o governo precisa atuar com processo material "não podemos agir como se fôssemos os donos da verdade" e de sua percepção do que esta ocorrendo por meio de processo mental "Leio nos jornais, nas revistas e vejo nas tevês que muitos estão surpresos com os movimentos recentes".

O Deputado Eduardo Sciarra usa principalmente processos mentais, relacionais e verbais. Combina mental com verbal quando diz "Quero agora também me manifestar a respeito disso". Coloca também a sociedade como dizente "a sociedade está manifestando neste momento". E caracteriza os protestos quando fala: "aquela era uma manifestação silenciosa da população". 
Na fala do Deputado Eurico Júnior prevalecem os processos verbais usados para parabenizar manifestantes e políticos: "Queria também parabenizar os manifestantes", “E parabenizar a atitude não só do Vaccarezza, do Guimarães e também do nosso VicePresidente Andre Vargas, que soube conduzir muito bem o movimento ontem”.

Quanto aos parlamentares de oposição, encontramos, no pronunciamento do Deputado Mendonça Filho, mais processos mentais seguidos de materiais. Ele coloca principalmente a necessidade de percepção (Processo mental) dos anseios do povo pelos parlamentares e a ação (Processo material) que os governantes devem ter ("A gente tem que ouvir a voz do povo e oferecer a resposta correta à sociedade, fazendo com que se mude a agenda.").

Arnaldo Jordy utiliza também mais processos mentais e materiais. Ele trata de seu sentimento: "Eu lamento a falta de reflexão diante dessas manifestações" e da necessidade de o governo agir "precisamos também estabelecer uma agenda mínima”.

O discurso do Deputado Carlos Sampaio apresenta uma predominância de processos relacionais. Encontramos, assim, a prevalência de definições, seja do movimento: "Este é um movimento em que pese difuso, este é um movimento em que pese disperso, este é um movimento sem dúvida de indignação", "O movimento é de indignação geral contra todos e contra toda a classe política", seja da situação dos políticos: "a indignação é generalizada e estamos todos na vala comum", seja a respeito de matérias que estavam na pauta da Câmara: "A luta em defesa da PEC 37 não é uma luta contra o Ministério Público, é uma luta contra a Nação".

Por último, temos a fala do líder da Minoria, Deputado Nilson Leitão. Nela encontramos principalmente processos materiais e relacionais, seguidos dos mentais. Ele também caracteriza as manifestações com o uso de processos relacionais: "É um movimento difuso e de várias camadas da sociedade", "Esse movimento da rua não tem proprietário". Procura traduzir o sentimento da população com processos mentais: "Mas muito mais do que da classe política, a sociedade se cansou do modelo que está ẩ’. E critica as ações do governo com processos materiais "O Governo brasileiro não conseguiu ter rumo, não conseguiu ter um projeto onde efetivamente melhore a vida da população". 
Ao fazer um levantamento dos tipos de processos que ocorriam nos excertos analisados, percebi que o processo mental foi o único tipo utilizado por todos os parlamentares. Ademais, pude constatar que o processo relacional foi, junto com o mental, o mais abundante. A maior presença desses dois tipos confirma a recorrência dos oradores na tentativa de definirem os movimentos de protesto e ao mesmo tempo refletir sobre ou chamar à reflexão acerca desses acontecimentos.

O modo como escolheram e empregaram os processos mentais chamou-me a atenção. Por esse motivo, criei a subseção abaixo para examinar melhor a gradação desse tipo de processo nos excertos analisados.

\subsubsection{Gradação dos processos mentais}

A gradação nos processos mentais consiste na variação com que eles podem ser apresentados. Dessa maneira, há diferença de polidez, por exemplo, entre o falante escolher dizer "eu quero" ou "eu gostaria” (processo mental desiderativo). Ou, ainda, "eu gosto", “eu amo", “eu adoro" (processo mental emotivo). Quanto aos mentais cognitivos, pode-se falar "eu acho" ou "eu sei", o segundo traz um grau maior de certeza.

\begin{tabular}{|c|c|c|c|c|c|c|}
\hline & Deputado & \multicolumn{5}{|c|}{ Processos mentais } \\
\hline \multirow{6}{*}{ Governo } & Alice Portugal & Quero dizer & $\begin{array}{c}\text { Queremos } \\
\text { sim fazer }\end{array}$ & & & \\
\hline & Henrique Fontana & $\begin{array}{r}\text { Querem uma } \\
\text { saúde }\end{array}$ & & & & \\
\hline & José Guimarães & $\begin{array}{r}\text { Não nos } \\
\text { sentimos }\end{array}$ & $\begin{array}{r}\text { A juventude } \\
\text { quer }\end{array}$ & & & \\
\hline & Mário Heringer & $\begin{array}{c}\text { Ouvir essa } \\
\text { sociedade }\end{array}$ & $\begin{array}{l}\text { A sociedade } \\
\text { não esquece }\end{array}$ & O pdt quer & O pdt quer & Se nós acharmos \\
\hline & Marcelo Castro & Supunha & Pensava & acreditava & & \\
\hline & Beto Albuquerque & $\begin{array}{r}\text { Eles não } \\
\text { querem }\end{array}$ & $\begin{array}{r}\text { Eles não } \\
\text { querem }\end{array}$ & $\begin{array}{r}\text { O povo } \\
\text { quer }\end{array}$ & $\begin{array}{r}\text { Precisamos } \\
\text { ouvir }\end{array}$ & \\
\hline
\end{tabular}




\begin{tabular}{|c|c|c|c|c|c|c|}
\hline & Anthony Garotinho & $\begin{array}{l}\text { A sociedade } \\
\text { parece que } \\
\text { quer }\end{array}$ & O povo sabe & vejam & & \\
\hline & Luis Carlos Heinze & $\begin{array}{l}\text { O povo está } \\
\text { enxergando }\end{array}$ & & & & \\
\hline & André Vargas & Quero só avisar & $\begin{array}{r}\text { Quero só } \\
\text { levantar }\end{array}$ & & & \\
\hline & José Humberto & $\begin{array}{l}\text { A população } \\
\text { não se sente }\end{array}$ & & & & \\
\hline & Dr. Carlos Alberto & $\begin{array}{r}\text { Leio nos } \\
\text { jornais }\end{array}$ & Vejo na tevê & $\begin{array}{r}\text { Vi um } \\
\text { jovem em } \\
\text { são paulo }\end{array}$ & $\begin{array}{r}\text { Precisamos } \\
\text { ouvir o } \\
\text { povo }\end{array}$ & \\
\hline & Eduardo Sciarra & $\begin{array}{l}\text { Quero me } \\
\text { manifestar }\end{array}$ & $\begin{array}{r}\text { Uma reflexão } \\
\text { que tem que } \\
\text { ser estudada }\end{array}$ & $\begin{array}{r}\text { Tem de ser } \\
\text { analisada }\end{array}$ & $\begin{array}{r}\text { Eu quero } \\
\text { deixar essa } \\
\text { constatação }\end{array}$ & \\
\hline & Eurico Júnior & $\begin{array}{r}\text { Queria } \\
\text { parabenizar }\end{array}$ & & & & \\
\hline \multirow{4}{*}{ Oposição } & Mendonça Filho & O Brasil ouviu & $\begin{array}{r}\text { Quem vive } \\
\text { percebe }\end{array}$ & $\begin{array}{r}\text { O povo } \\
\text { quer }\end{array}$ & $\begin{array}{r}\text { A gente tem } \\
\text { que ouvir }\end{array}$ & precisam ouvir \\
\hline & Arnaldo Jordy & Queria festejar & $\begin{array}{r}\text { Lamento a } \\
\text { falta de } \\
\text { reflexão }\end{array}$ & Eu acho & acho & \\
\hline & Carlos Sampaio & $\begin{array}{l}\text { Cabe a nós } \\
\text { percebê-lo }\end{array}$ & Eu penso & $\begin{array}{r}\text { Não } \\
\text { estaremos a } \\
\text { perceber }\end{array}$ & $\begin{array}{r}\text { Precisamos } \\
\text { ouvir }\end{array}$ & \\
\hline & Nilson Leitão & $\begin{array}{r}\text { Ouvi da líder } \\
\text { do PC do B }\end{array}$ & $\begin{array}{r}\text { Eu me lembro } \\
\text { daquele } \\
\text { coitadinho }\end{array}$ & $\begin{array}{r}\text { A } \\
\text { sociedade } \\
\text { se cansou }\end{array}$ & $\begin{array}{r}\text { Ouçam esse } \\
\text { povo }\end{array}$ & \\
\hline
\end{tabular}

Quadro 6- Gradação dos processos mentais

Ao lançar um olhar sobre as ocorrências de processos mentais nos excertos, vi que os parlamentares da situação discorrem muitas vezes sobre o que o povo quer e sobre o que não quer também, por meio dos processos mentais desiderativos. Já os da oposição utilizam os mentais cognitivos para expressar sua percepção dos eventos (eu acho, eu penso). O uso 
do verbo querer como locução (já tratada na seção 4.2) é frequente na fala dos governistas, tornando menos direto o pronunciamento desses. Além disso, verifiquei que, nos discursos dos que apoiam o governo, há mais descrição de como a população se sente, o que ela vê e deseja com processos mentais desiderativos "querer", “desejar" e perceptivo "enxergar"; em contraste com os da oposição, que colocam a si mesmos como sujeitos na maioria das vezes em que usam os processos mentais, principalmente os perceptivos "perceber” e “ouvir" e os cognitivos "lembrar" e "pensar". Isso dá para a fala dos primeiros a aparência de que conhecem melhor os anseios do povo.

Finalmente, a constatação de que é necessário ouvir a população aparece tanto nos discursos da base do governo quanto nos dos oposicionistas (Precisamos ouvir, A gente tem que ouvir, ouçam esse povo e cabe a nós percebê-lo (processo mental perceptivo)) . Tal aspecto revela a reação geral dos parlamentares de que necessitam refletir sobre o momento e buscar entender as reivindicações da população.

\subsection{Representação}

Usando como referência teórica Fairclough (2003), investiguei a forma como eventos e atores sociais foram representados nos discursos parlamentares.

Fairclough ressalta que textos que representam os mesmos aspectos do mundo dentro da mesma rede de práticas sociais se diferenciam quanto ao que escolhem destacar (p.90 (127)). Dessa maneira, num texto um ator social pode ser referido como agente dominante e em outro discurso nem aparecer. Seguindo essa orientação, pude notar que os seguintes atores sociais diferem quanto à forma como são representados nos discursos parlamentares analisados nesta pesquisa, são eles: polícia, o governo, o Brasil e a emissora de televisão Rede Globo.

A polícia militar, escalada para coibir atos de violência e vandalismo durante os protestos, foi mencionada em algumas falas e em outras não. Quando lembrada, foi elogiada por uns e criticada por outros. Dos dezesseis discursos, apenas cinco fazem menção aos policiais. 
Alice Portugal censura a "agressão policial" e a "repressão policial" empreendidas em alguns protestos, especialmente em São Paulo, estado governado pelo PSDB, partido de oposição. Ela diz: “A verdade é que a atitude belicosa da Polícia paulista levou a um processo de solidariedade nacional e até internacional. A agressividade desmedida, a ação absolutamente intransigente daquele corpo militar, infelizmente, assustou o Brasil, e toda a revolta que havia em relação a essa situação da mobilidade urbana gerou essa expansão dessa batalha”.

Eurico Júnior, no entanto, elogia a atuação policial no protesto ocorrido no dia anterior em Brasília. "Eu queria aproveitar para parabenizar a PM aqui de Brasília". Assim como o líder do PT que elogia o comportamento do governador do DF, que pertencia a seu partido: "Portanto, quero elogiar o Governador Agnelo, que, com a sua Polícia, garantiu a preservação da ordem pública", numa contraposição a atitude do governo tucano em São Paulo.

Garotinho, por sua vez, cita os policiais como parte dos manifestantes que faziam reivindicações aos parlamentares. O deputado afirma que eles solicitavam a votação da PEC 300/2008, Proposta de Emenda à Constituição, que trata da isonomia salarial entre policiais e bombeiros dos estados e do Distrito Federal. "Lá estavam também, e eu vi - por telefone, conversei, inclusive, com um deles -, policiais militares e bombeiros perguntando: "Cadê a PEC 300, que vocês prometeram, votaram em primeiro turno, aprovaram, e não se fala mais nisso?" "A PEC 300 dá um salário digno aos policiais".

Por último, Nilson Leitão faz referência à polícia como força repressora utilizada pelo Governo Federal “colocam 1.800 policiais, para que não se aproxime do Palácio do Planalto ou da casa da Presidente".

Nesse aspecto, vemos os parlamentares da base do governo criticando a atuação da polícia comandada pelo governo do PSDB e parabenizando a dirigida pelo governo do PT. Dessa maneira, os governistas não aparecem como repressores aos movimentos, mas tentam se identificar com os manifestantes ao lembrar sua história de vítimas de repressão como partidos de esquerda na ditadura militar. Garotinho, cujo partido político à época também compunha a base do governo, se aproxima do povo e dos policiais ao defender 
uma das reivindicações dos protestos que era a votação em segundo turno da PEC 300. Curiosamente, nesse discurso, os policiais surgem como pessoas que reivindicam. Esse deputado em lugar de atribuir a reação violenta aos protestos à polícia diretamente, culpa o governador do Rio de Janeiro, que comanda as forças policiais: "Então, eu apelo à serenidade do Governador do Estado, porque ontem a reação foi à base de tiro de fuzil".

Outro ator social que teve tratamento diferente nos discursos foi a emissora de televisão Rede Globo. Ela foi alvo de alguns protestos, contudo, apenas dois Deputados a mencionaram. Das dez ocorrências, nove constavam do discurso do Deputado Anthony Garotinho e uma da fala do Deputado André Vargas. A imprensa foi hostilizada em algumas manifestações, no entanto, somente esses dois parlamentares incluíram esse fato em seus discursos e só o nome dessa emissora foi apontado. Ao reproduzir por nove vezes o nome Rede Globo, o Deputado Garotinho criticou aquela empresa e, por seis vezes, associou seu nome ao verbo manipular “a Globo manipula o povo, manipula a informação; que a Globo manipulou informações na eleição presidencial Lula-Collor; que a Globo manipulou na abertura política do Brasil; que a Globo manipulou durante a ditadura militar; que a Globo manipulou na bomba do Rio Centro". Com isso, o político desvaloriza, desconstrói, desacredita o discurso do meio de comunicação que nem sempre lhe é favorável. O Deputado André Vargas, por sua vez, no curto pronunciamento que faz em resposta a um colega, argumenta que os protestos tinham uma pauta ampla e não se prestavam apenas a criticar o governo do PT e por isso fez referência à Globo "Houve manifestação contra a Rede Globo, houve manifestação a favor dos indígenas, há o debate sobre a questão dos direitos humanos".

Quanto à representação de governo, chamou-me a atenção o fato de sete discursos não trazerem qualquer referência a esse termo. Os Deputados Alice Portugal (PC do B), Mário Heringer (PDT), Anthony Garotinho (PR), Luis Carlos Heinze (PP), José Humberto (PHS), Dr. Carlos Alberto (PMN) e Eurico Júnior (PV) simplesmente não mencionam a palavra governo. Para os outros nove Deputados, a palavra tem o sentido, principalmente, de Governo Federal ou governo da situação, Marcelo Castro fala nas diferentes esferas (federal, estadual e municipal), os parlamentares petistas falam em "nosso governo" e Arnaldo Jordy menciona "governos" apenas uma vez com significado genérico. 
Examinando os discursos dos oradores que não empregaram o vocábulo "governo", constatei que o mote da fala de Alice Portugal é expressar que o PC do B está perfilado com o povo, como um partido que escuta o clamor das ruas e criticar a violência policial. Já Mário Heringer fala em ouvir a sociedade. Anthony Garotinho não usa a palavra governo, mas menciona o governador do Rio de Janeiro e o de São Paulo, pelo cargo, sem citar os nomes. Seu discurso foca na responsabilidade do Congresso de votar projetos que beneficiam a população e, como outros parlamentares faz um reconhecimento de culpa, enquanto Deputado, do que está acontecendo nas ruas, dos motivos dos protestos. O fato de Luis Carlos Heinze não usar o termo "governo", não significa que ele não mencione os governantes, o parlamentar opta por tratar da 'União', 'o Executivo', 'Colégios Legislativos'. Em outros momentos, o orador oculta os agentes com orações ao deixar os sujeitos indeterminados: "Querem expropriar milhões de hectares de gente que legitimamente está em cima da terra", "Prometem muito em todas as áreas, agora não se consegue executar". Quem quer? Quem promete? Quem não executa? O parlamentar prefere não esclarecer. José Humberto é outro parlamentar que não menciona 'governo'. Fala da necessidade de reforma do Parlamento e de acontecimentos sem explicitar o agente "manifestação principalmente dos nossos jovens em relação a sérios problemas que o País vive”. Sem apontar quem seria responsável por esses problemas. Dr. Carlos Alberto escolhe criticar o comportamento dos parlamentares e que esses precisam ouvir o povo para melhor representa-los. E, finalmente, Eurico Júnior utiliza sua fala para parabenizar a Polícia Militar e os parlamentares que atuaram no dia anterior.

Fairclough fala também da relação dialógica dentro e entre os discursos (2003, p.91). Alguns pronunciamentos são respostas à fala de outros parlamentares ou à fala da Presidente da República ou a algo ouvido do povo nas ruas. Os próprios discursos são misturados ou híbridos, citam a fala da Presidente e a de manifestantes e a de outros Deputados. Henrique Fontana menciona o apelo de seus pares para que se vote a reforma política: "a maior parte dos colegas que me encontram todas as semanas ali no cafezinho me perguntam: "Fontana, por que nós não vamos votar a reforma política?". O líder do PT, José Guimarães, inclui o discurso da Presidente da República "Como lembrou a Presidenta Dilma Rousseff, hoje, lá no Palácio do Planalto: "O Brasil acordou nesta terça- 
feira mais forte...". Enquanto o Deputado Marcelo Castro do PMDB minimiza o movimento à classe média, o líder do PT responde a essa fala, lembrando que o governo do PT é o responsável pela ascensão social de parte da população "uma geração que foi alçada à condição de classe média, até pelas políticas públicas do nosso Governo...”.

\subsubsection{Representação segundo Van Leeuwen}

Ao considerar a classificação dos atores sociais de acordo com a taxonomia de van Leeuwen (2008), pude constatar que os manifestantes não são individualizados em nenhum discurso. Os jornalistas também não são. Embora alguns parlamentares tenham mencionado a violência policial, eles não nomearam suas vítimas, mesmo que alguns casos tenham tido grande repercussão na imprensa.

Em alguns discursos, como no da Deputada Alice Portugal, há exclusão do povo por encobrimento, a parlamentar usa metáforas e metonímias para se referir aos manifestantes em alguns momentos, em outros apenas a ação de manifestar está presente. Outros parlamentares usam a nominalização "manifestações" para encobrir esse ator social. A população é, ainda, representada em termos de espacialização seja com o termo "ruas", seja como "Brasil".

Os congressistas, por sua vez, são por vezes incluídos de forma específica, individualizada, são nomeados, obtendo, dessa forma, maior destaque.

Há casos do povo sendo representado por agregação, ou seja, de forma numérica, como estatística : "Os milhares de manifestantes deram um duro recado aos governantes de todas as instâncias e aos três Poderes da República". Nesse exemplo, há também o que van Leeuwen (2008) chama de associação, entre governantes e os três poderes da República, o beneficiário não é especificado. Quando o orador escolhe ser incluir um ator, mas de forma mais genérica, ele pode se valer da impessoalização por abstração, aí encontramos o uso de "sistema democrático brasileiro" e "democracia representativa", por exemplo, que precisam de um "parlamento forte”, assim, não é a população quem precisa, mas um sistema. 
Há ocorrências, no entanto, de representações bem específicas. Alguns deputados escolheram mencionar nome e cargo de alguns atores sociais envolvidos na prática social aqui estudada, esses atores eram políticos e ganharam destaque nessas falas, como no seguinte excerto: “E parabenizar a atitude não só do Vaccarezza, do Guimarães e também do nosso Vice-Presidente Andre Vargas, que soube conduzir muito bem o movimento ontem". O uso do pronome possessivo "nosso" revela que o orador quis demonstrar proximidade, seu partido era da base do governo. Quando o orador não menciona o cargo de deputado, mas apenas o sobrenome dos outros dois parlamentares, também evidencia familiaridade.

Num levantamento sobre quem exerce agência ou quem é o Ator/Experienciador dos Processos Materiais e Mentais, verifiquei o seguinte:

\begin{tabular}{|l|r|r|r|}
\hline & \multicolumn{3}{|c|}{ Sujeito } \\
\cline { 2 - 4 } & Povo & Governo & \multicolumn{1}{l|}{ Outros } \\
\hline Proc. Material & 9 & 25 & 4 \\
\hline Proc. Mental Desiderativo & 7 & 10 & \\
\hline Proc. Mental Cognitivo & 2 & 15 & 3 \\
\hline Proc. Mental Emotivo & 2 & 2 & \\
\hline Proc. Mental Perceptivo & 1 & 10 & 2 \\
\hline
\end{tabular}

Quadro 7- Posição de Sujeito

Considerei como Governo eu, nós e todos que se relacionavam a partidos e instituições políticas. Já como Povo, classifiquei todos os atores ligados às manifestações. Outros são os sujeitos indeterminados, além do Brasil, a PM, a reflexão e o aumento da passagem.

Como pôde ser visto, os atores relacionados ao Governo têm a supremacia em todos os tipos. Eles ocorrem 25 vezes atrelados a verbos de ação, ou seja, são aqueles que fazem, que realizam.

Quando analisamos os Experienciadores, verificamos que o Governo aparece principalmente nos Processos Mentais Cognitivos, é ele quem pensa, percebe, entende, sabe, na maior parte das ocorrências. Nesse tipo de processo, o Povo é o Experienciador apenas duas vezes. Nos Perceptivos, também há predominância de atores ligados à Política, 
são eles que ouvem e veem. Quando observamos os Desiderativos, no entanto, encontramos uma representação mais próxima, o Povo aparece sete vezes como quem quer algo. Nos Emotivos, temos duas ocorrências para cada. Concluímos, então, que a principal reação da população, segundo os discursos, é desejar alguma coisa, enquanto para os políticos é pensar e refletir sobre os acontecimentos. Trago abaixo alguns exemplos para ilustrar essa explanação:

Processo Material com Ator ligado ao governo:

E esta Casa tem que construir uma outra agenda, para podermos dar vazão a essas manifestações ocorridas no Brasil afora.

Nós só mudaremos a visão que têm da gente com postura.

Processo Material com Ator ligado ao povo:

Infelizmente, senhoras e senhores, esse movimento chegou tarde.

Processo Material com outros atores:

A passagem, os 20 centavos da passagem foram os 20 centavos mais benditos que aconteceram para a sociedade brasileira, porque trouxeram os brasileiros, e nós desta Casa estarrecidos e extasiados pelo sucesso de uma manifestação que já deveria ter ocorrido.

Processo Material com Ator ligado ao governo e Processo Mental Desiderativo com Experienciador relacionado ao povo:

Infelizmente, o que nós fazemos e o que temos feito não mais atende ao que essa sociedade quer.

Processo Mental Desiderativo com Experienciador relacionado ao povo: 
É evidente que a população que foi às ruas ontem, Presidente Biffi, especialmente os mais jovens, que foram maioria nas manifestações, querem uma saúde pública cada vez melhor, querem uma educação cada vez mais qualificada, querem transporte público mais barato e em condições cada vez mais qualificadas.

É evidente que o povo quer sempre mais.

Processo Mental Cognitivo com Experienciador relacionado ao governo:

Nosso Governo entende os movimentos que ocorreram ontem como um alerta para que nós continuemos aprofundando mudanças, reconhecendo erros, ampliando conquistas e, acima de tudo, sabendo que nunca um país está pronto e que nunca alguém pode se sentir o dono da verdade.

Eu penso que é hora de o Parlamento saber escutar este pulsar das ruas.

Processo Mental Cognitivo com Experienciador relacionado ao Povo:

O povo que foi para as ruas sabe que aquele dinheiro todo que foi gasto em obra para turista na Zona Sul do Rio de Janeiro é o dinheiro que falta na Zona Norte, na Zona Oeste, nos bairros mais pobres, nas comunidades mais humildes.

\subsection{Análises dos Discursos}

Apresento a seguir a análise de cada discurso separadamente. Tendo como norte as questões de pesquisa constantes do Capítulo 3 desta Dissertação e as descrições conforme o Sistema da Transitividade e o Sistema de Modo, além da classificação dos atores sociais segundo van Leeuwen (2008), descrevi aquilo que mais chamou minha atenção em cada pronunciamento. 
ALICE PORTUGAL (PCdoB- BA- Como Líder)

Ao estudarmos a representação do povo no discurso da líder do PC do B, percebemos a exclusão desse ator social por encobrimento. Van Leeuwen (2008, p. 29) faz distinção entre dois tipos de exclusão de agentes sociais: a supressão e o encobrimento ou backgrounding. No primeiro, o agente e suas ações não aparecem no texto e só podemos descobri-los comparando diferentes representações do mesmo evento. No segundo, embora o ator social seja excluído, suas atividades são mencionadas e encontramos referência em alguma parte do texto que nos leva a perceber quem atuou. Dessa maneira, nos excertos da Deputada Alice Portugal, ações relevantes são incluídas (manifestar), mas o agente (povo) não foi claramente mencionado. Isso ocorreu por meio do uso de nominalização, metáfora e metonímia. Os termos escolhidos pela oradora foram: manifestações, voz das ruas e mobilização das ruas.

Em "As manifestações que eclodiram País afora, inicialmente lastreadas na luta em defesa da não elevação dos preços das tarifas dos transportes, ganhou contornos difusos e espalhou-se pelo país", "manifestações" desempenha a função de Ator, no entanto, a nominalização esconde o agente, que é o povo. A atividade de manifestar é incluída, mas não quem age. O mesmo acontece em "Quero dizer que temos de constituir uma pauta adequada para abraçar este momento de mobilização das ruas, de onde nós saímos", a deputada não fala quem está mobilizado. Nesse trecho, observamos também o uso do verbo "querer" com o fim de modalizar. Em outra parte ela diz: "Queremos sim fazer uma pauta consonante com a voz das ruas". O verbo no plural inclui dessa vez seus pares, contudo, demonstra apenas o desejo de agir, ela permanece no campo da volição. Aí temos novamente o encobrimento do ator social, dessa vez por metonímia e, de acordo com a taxonomia proposta por van Leeuwen (2008), impessoalização por objetivação e espacialização, isto é, escolhe falar do lugar "ruas" para referir-se ao povo que se manifestava. Ruas é a metáfora usada para trazer de forma indireta o povo para essa fala.

Outro recurso empregado pela oradora é a adjetivação, que é quando o falante transforma um nome em adjetivo. Ela expressa que é necessário "repudiar a agressão 
policial desmedida e também atitudes infiltradas que visam constituir vandalismos", nesse exemplo, um adjetivo (policial) revela e outro encobre (infiltradas). Há nominalização também apagando agentes em "atitudes" e "vandalismo".

Quanto aos parlamentares, observei a nomeação de dois deputados, Biffi e André Vargas:

“Em tempo, Presidente Biffi, parabenizo o Presidente em exercício da Casa, o Deputado Andre Vargas, que teve atitude serena, auspiciosa, de compreender a voz das ruas e não empreender uma repressão policial, como foi empreendida em outros lugares deste País."

O primeiro como vocativo e o segundo como alvo, ambos de forma passiva com nomeação formal. A atitude do Presidente em exercício da Casa, Deputado André Vargas é tida como "serena e auspiciosa", digna de ser parabenizada. A oradora contrapõe seu comportamento ao de outras autoridades que lançaram mão de forte repressão policial. Os protestos ocorreram em vários estados do país, mas um dos lugares em que, segundo a imprensa, houve forte represália da polícia foi São Paulo, cujo governador era do PSDB, partido de oposição ao governo. A líder poderia contrapor aí a reação do PT e de seu opositor diante dos protestos.

Por último, tratando de polaridade que é a escolha entre o positivo e o negativo por meio de sentenças afirmativas ou negativas (FUZER \& CABRAL, 2010, p. 118), vejo que outro ponto que me chamou a atenção no discurso da deputada foi o uso da polaridade positiva, normalmente não marcada, com o objetivo de enfatizar a intenção dos parlamentares de agirem no sentido de atenderem às reivindicações populares: “Queremos sim fazer uma pauta consonante com a voz das ruas, mas, ao mesmo tempo, consagrando as vitórias adquiridas, porque elas não vieram de graça”. A parlamentar ressalta, no entanto, a atuação prévia, provavelmente do governo, que gerou vitórias. 


\section{HENRIQUE FONTANA (PT-RS- Líder do Governo)}

O Deputado Henrique Fontana discursa como líder do governo nos excertos analisados nesta pesquisa. Logo no início, ele já revela que sua fala está alinhada com a da Presidente da República:

"A minha primeira frase está em sintonia com a nossa Presidenta Dilma, que hoje pela manhã expressou o seu apoio, como não poderia deixar de ser, a manifestações que, de forma pacífica, na sua ampla maioria, reivindicam mudanças ainda maiores no nosso País."

Mais uma vez, temos a exclusão do povo por encobrimento pelo uso da nominalização "manifestações", nesse caso, sem artigo definido, de maneira genérica. A expressão "ainda maiores" reforça o pensamento de que esse governo já produziu outras mudanças no Brasil. "Como não poderia deixar de ser", por sua vez, é um recurso do Sistema de Modo, um Adjunto de Comentário que dá a ideia de algo óbvio, no entanto, conforme estudo feito por Castells (2013) a respeito de manifestações de protesto no mundo a partir da Primavera Árabe, em 2010, não era uma atitude comum a autoridade máxima do país se pronunciar a respeito dos protestos. O líder do governo, assim como outros parlamentares da base, procuram enfatizar essa aproximação do governo do PT com as ruas.

O povo é incluído no excerto a seguir por meio dos termos "população" e "os mais jovens".

“É evidente que a população que foi às ruas ontem, Presidente Biffi, especialmente os mais jovens, que foram maioria nas manifestações, querem uma saúde pública cada vez melhor, querem uma educação cada vez mais qualificada, querem transporte público mais barato e em condições cada vez mais qualificadas."

O deputado segmenta e reduz a parcela do povo descontente ao especificar que quem deseja melhorias é "a população que foi às ruas ontem, especialmente os mais jovens". Quando ele fala "cada vez melhor" e "cada vez mais qualificada", demonstra que o nível de exigência da população teria aumentado e não que as condições dos serviços 
fossem precárias. Ademais, faz repetições do processo mental desiderativo "querem” para enfatizar o desejo da população.

\section{JOSÉ GUIMARÃES (PT-CE - Líder do PT)}

O Deputado José Guimarães fala como líder do PT nesse discurso. Nos excertos analisados, encontramos vinte referências ao povo e nove que dizem respeito ao governo.

A expressão "a bancada do PT na Câmara” ocorre como Dizente e Sujeito, é uma inclusão por ativação, pessoalização e categorização. A categorização ocorre quando o ator social é identificado de acordo com identididades e funções que ele compartilha com outros (LEEUWEN, 2008, p.40). Na mesma sentença, temos manifestações como Alvo e Complemento, aí ocorre impessoalização por assimilação, coletivização.

O parlamentar reproduz a fala da Presidente da República:

"O Brasil acordou nesta terça-feira mais forte com as manifestações realizadas em todo o País, comprovando a energia da nossa democracia, a força das vozes da rua e o civismo de nossa população".

Nesse caso, encontramos o povo representado como "o Brasil", uma inclusão por ativação, por impessoalização por espacialização (representação com referência ao lugar em que está. Nesse caso, brasileiros são substituídos por Brasil). Ele é o comportante que acorda. Diversas notícias falavam do gigante que acordou referindo-se ao despertar dos cidadãos para reivindicar seus direitos. Na mesma sentença vemos ainda "manifestações", "energia da nossa democracia", "força das vozes das ruas", "civismo da população" incluídas por passivação, impessoalização, assimilação e coletivização (Aparecem de forma passiva, ou seja, não são o agente da oração. A coletivização é uma forma de tratar os atores como grupo, não individualizar). A Presidente e o deputado que fazem, assim, uma avaliação, exaltando qualidades dos manifestantes. O povo é incluído por suas características. 
Nesse discurso, encontramos muitas ocorrências de processos relacionais, que são usados para caracterizar e identificar. No intuito de compreender e explicar os protestos, os parlamentares se valem desses processos. Assim, na fala desse líder, as "manifestações" e "reivindicações" aparecem como portadores cujos atributos são "legítimas" e "parte do sistema democrático brasileiro", respectivamente: "As manifestações são legítimas e as reivindicações e os métodos para expressá-las fazem parte do sistema democrático brasileiro".

A única ocorrência de representante do povo como Ator vem em "Os milhares de manifestantes deram um duro recado aos governantes de todas as instâncias e aos três Poderes da República". Aí ocorre impessoalização por assimilação e agregação (A agregação quantifica grupos de participantes, tratando-os como estatística). O beneficiário da ação é generalizado, ocorre uma associação entre governantes e os três poderes da República, o alvo do duro recado não seria apenas o governo do PT.

Depois disso, temos "a bancada do PT e nosso governo" como portador e "reivindicações expressas nas ruas" como atributo, numa aproximação do partido com a sociedade que protesta. Isso acontece também em “O povo na rua é nossa história”, em que identificador e identificado trazem a igualdade entre os manifestantes e o partido político aqui representado. Já a necessidade de ouvir os anseios da população é impessoal e abstrata (de todos os poderes). Utilizando a polaridade negativa duas vezes, o orador parece querer contrapor a fala de colegas da oposição.

Há apenas uma ocorrência de ator social ligado ao governo como ator, ela vem como modulação de obrigação no último excerto analisado: "E esta Casa tem que construir uma outra agenda, para podermos dar vazão a essas manifestações ocorridas no Brasil afora". Nesse caso, há impessoalização por objetivação e espacialização (esta Casa) e a obrigação é construir uma agenda que dê vazão às manifestações, ou seja, que esvazie as ruas. Quando observamos o penúltimo excerto, vemos que há um contraponto entre o povo, que aparece como experienciador e deseja, e o governo que ocorre como o ator e que pode fazer essa agenda. "É a juventude do Brasil, que agora quer construir uma outra agenda". 
Há representação por impessoalização e abstração em: sistema democrático brasileiro, reivindicações expressas nas ruas, democracia representativa e todos os poderes. Essa pode ser uma forma de apagar ou encobrir o povo e, no último caso, incluir os governantes de forma indireta.

\section{MÁRIO HERINGER (PDT-MG. Como Líder do PDT)}

No discurso do líder do PDT, encontramos o povo representado principalmente como "essa sociedade" (experienciador, atributo, receptor e fenômeno) e também como "a sociedade" (Dizente, Atributo, Experienciador). O orador escolhe também os termos: ela (Experienciador e Ator), a sociedade brasileira (Beneficiário), os brasileiros (Meta), um Brasil que participa (Circunstância), um Brasil que reivindica (Circunstância) e povo brasileiro (Possuído). O povo aparece como Ator em uma sentença encaixada numa verbiagem em que o parlamentar declara que é preciso avisar a sociedade que é ela quem os comanda: "Está na hora de ouvir essa sociedade e de dizer para essa sociedade que é ela que nos comanda". Em outro momento, também como Ator, o orador usa o termo "movimento" e critica o fato de estar atrasado: "Infelizmente, senhoras e senhores, esse movimento chegou tarde". Caracteriza, no entanto, os manifestantes como pessoas que agem: "um Brasil que reinvidica, um Brasil que participa".

Os parlamentares ou governantes, por sua vez, são exibidos como: a gente (Ator), nós (Receptor, Ator, Dizente, Circunstância, Portador, Possuidor, Experienciador), nos (Meta), nós desta Casa (Meta), o PDT (Experienciador), nós mesmos (Possuído), esta Casa (Possuído). O deputado revela preferência pelo pronome "nós", usado nove vezes, em detrimento de "a gente" utilizado apenas uma vez, esse último é menos formal e é usado quando o orador quer se aproximar dos seus ouvintes.

A modalização está presente por meio da polaridade negativa que revela a falta de atendimento das necessidades da população, a falta de respeito do povo pelos políticos e a falta de esquecimento da sociedade. Ocorre modalização também no uso, por duas vezes, do adjunto de comentário "infelizmente" e da metáfora interpessoal "está na hora", que 
conclama os parlamentares a fazerem algo, no caso, conversar com a sociedade. "Infelizmente, o que nós fazemos e o que temos feito não mais atende ao que essa sociedade quer" e "Está na hora de ouvir essa sociedade e de dizer para essa sociedade que é ela que nos comanda." Avalia o movimento de protesto como tardio e o aumento das passagens como bendito, por ter despertado os brasileiros. "Infelizmente, senhoras $e$ senhores, esse movimento chegou tarde", "A passagem, os 20 centavos da passagem foram os 20 centavos mais benditos que aconteceram para a sociedade brasileira". O deputado faz uso de repetições para enfatizar seu pensamento. Nesse aspecto, encontramos a repetição de "ouvir essa sociedade", "está cansada", "bater palmas para um Brasil".

O orador coloca-se do lado do governo e fala na perspectiva de "nós" governo versus "essa sociedade": "o que nós fazemos e o que temos feito não mais atende ao que essa sociedade quer". O adjunto de modo "não mais" informa mudança, pois no passado o que era feito pelo governo atenderia a população, segundo o orador. O povo é, na maioria das vezes, representado como Experienciador, aquele que quer algo, enquanto o governo é o Ator, ou seja, aquele que faz. O parlamentar reforça a obrigação dos governantes de ouvirem a sociedade por meio do plebiscito, maneira que foi proposta pela Presidente da República. Em sua fala, ele demonstra que a posição de seu partido é de parar para ouvir e conversar com a sociedade, em lugar de agir imediatamente. Ele expressa a posição de seu partido, o PDT, utilizando processo mental desiderativo. Dessa forma, é menos direto ao dizer que o PDT quer colocar sua posição de conversar e ouvir a sociedade. Aí o partido é incluído de forma ativa e a sociedade de forma passiva.

"o PDT quer colocar a sua posição de parar. Não vamos tomar decisões açodadas e correndo. É parar e conversar com a sociedade, é ouvir a sociedade".

\section{MARCELO CASTRO (PMDB-PI. Como Líder do PMDB)}

No discurso do líder do PMDB, temos a redução dos manifestantes a uma classe social específica. O parlamentar utiliza diversos recursos gramaticais (advérbio de modo, 
vocativo, perguntas) que explicitam a Metafunção Interpessoal para convencer sua audiência de que não se trata de um descontentamento generalizado. "Primeiro, isso é um movimento nitidamente da classe média brasileira". "Agora, Sr. Presidente, o que é esse movimento de classe média?".

Num outro trecho, ele utiliza a gradação de processos mentais em mais um questionamento: "Quem de nós, verdadeiramente, supunha, pensava, acreditava que pudesse haver no Brasil tamanha insatisfação?". Além do mais, o verbo no passado do modo subjuntivo (pudesse) atenua a existência, apresenta de forma menos direta a insatisfação avaliada como "tamanha". Nesse excerto, temos o apagamento do povo como ator social, há um encobrimento pelo emprego da nominalização (insatisfação), pois o Deputado não fala quem estava insatisfeito. O ator social "quem de nós" demonstra diferenciação (nós parlamentares versus eles insatisfeitos). E finalmente, o adjunto de comentário "verdadeiramente" reforça a veracidade da perplexidade do orador.

Mais à frente, temos movimentos populares como Existente, algo que acontece sem ação de alguém. E a classe média é tida, novamente, como a portadora da insatisfação:

"Foi preciso haver esses movimentos populares para que nós caíssemos na real e víssemos o quanto a sociedade brasileira, especialmente a classe média brasileira, está insatisfeita."

Encontramos, por fim, um processo material cujo Ator são os parlamentares. A polaridade negativa demonstra a falta de ação dos representantes do povo:

\footnotetext{
"Tivemos a oportunidade de avançar, de aproximar o Parlamento do povo brasileiro, de fazer partidos programáticos que pudessem representar correntes de pensamento nacional, e não $o$ fizemos".
} 
BETO ALBUQUERQUE (PSB-RS. Como Líder do PSB)

Esse discurso traz o eu do orador como Dizente falando em nome de seu partido, os manifestantes são representados de forma metonímica por "ruas e avenidas" que falam. Os processos relacionais são usados nessa fala também com o fim de definir o movimento, que aparece como Atributo. A voz das ruas, também Dizente, pede para ser ouvida.

Há ainda os papéis de Experienciadores. Os políticos são os Experienciadores perceptivos, que devem ouvir a população, enquanto o povo é o Experienciador desiderativo, aquele que deseja algo. As duas sentenças com polaridade negativa revelam o que o povo não quer, mostrando a realidade do cidadão usuário de transporte público.

Por último, os parlamentares aparecem como Atores que devem fazer a parte deles e olhar para a pauta do povo, que segundo o discurso parece ser diferente da pauta do governo. Os governantes como representantes do povo deveriam levar seus anseios aos debates políticos, no entanto, tal fala revela duas pautas com interesses diversos.

\section{ANTHONY GAROTINHO (Bloco/PR-RJ. Como Líder)}

Esse orador não exclui o povo, ele usa esse termo diversas vezes, principalmente como Dizente como, por exemplo, nos excertos a seguir: “Ontem o povo dizia: 'Fora, Rede Globo". "As pessoas colocaram para fora muitas frustrações que precisavam colocar e desejavam colocar, e não tinham canal para colocar". No último, notei a repetição do verbo colocar, indicando a verbalização da população.

Outro aspecto que me chamou a atenção foi a modalização com emprego do verbo parecer. Dessa forma, o orador reduz a força asseverativa da oração encaixada e revela comprometimento fraco com aquilo que é dito. Assim temos: "A sociedade parece que quer dar um passo adiante" e "A sociedade parece que está dizendo que quer ir para a democracia participativa". 
O Deputado faz uso do verbo no infinitivo para excluir um agente em:

"Dizer que aquelas pessoas são baderneiras, dizer que é uma luta sem causa ou fazer qualquer afirmação conspiratória neste momento seria precipitado por parte de qualquer pessoa".

Tal comportamento poderia ser atribuído a parte da imprensa que, no início, referiu-se aos manifestantes como vândalos, pois o parlamentar menciona a Rede Globo por duas vezes nos excertos selecionados.

O líder é assertivo ao afirmar o que o povo sabe, mas não se compromete tanto quando fala da intenção do povo de caminhar para uma democracia participativa. "O povo, ontem, estava revoltado, porque sabe ..."

"O povo que foi para as ruas sabe que aquele dinheiro todo que foi gasto em obra para turista na Zona Sul do Rio de Janeiro é o dinheiro que falta na Zona Norte, na Zona Oeste, nos bairros mais pobres, nas comunidades mais humildes."

O deputado escolhe reproduzir a fala do povo contra a emissora de televisão (“Fora, Rede Globo!”) e exalta a força do povo ao fazer menção da retratação do telejornal aos manifestantes:

"Vejam que a força do povo é tão grande que, no Jornal Nacional de ontem, a Rede Globo praticamente pediu desculpas pela cobertura errônea que vinha dando ao movimento".

\section{LUIS CARLOS HEINZE (PP-RS.)}

Nos excertos analisados desse discurso, o povo aparece por duas vezes como Sujeito (Ator e Experienciador). Nós, representando os parlamentares, também ocorre por duas vezes como Sujeito, nas duas como Ator. Cabe aos deputados unir as vozes da rua 
com as vozes da Casa (Meta). Por duas vezes também, temos a representação do povo por pessoalização e indeterminação (pessoas de bem, aqueles que sem partidarizar estão indo às ruas), uma representação de maneira não específica.

Falsas promessas aparecem como o principal motivo dos protestos, apontado por duas vezes pelo deputado, que não explicita quem as faz. O parlamentar usa nominalizações (corrupção, sacanagem, safadeza, falsas promessas) para encobrir os autores das ações que prejudicam o povo.

"Nós vamos nos juntar, vamos nos somar às pessoas de bem, contra a corrupção, contra a sacanagem, contra a safadeza $e$, principalmente, contra as falsas promessas, porque tem alguém que tem que pagar essa conta".

Revela, no entanto, aqueles que corrompem os políticos.

"O povo está enxergando isso: a corrupção que existe hoje, seja no Executivo, seja dentro dos próprios colégios Legislativos, mas também há os corruptores. Temos que ver os empresários que corrompem os corruptos".

Os governantes são representados, nesse excerto, por espacialização (no Executivo, o Legislativo), faz referência aos poderes a que pertencem os órgãos onde os políticos atuam; enquanto os empresários são representados por categorização (categoria profissional).

O povo aparece por duas vezes como Sujeito (Ator e Experienciador). "Nós", representando os parlamentares, também ocorre por duas vezes como Sujeito, nas duas como Ator. Cabe aos deputados unir as vozes da rua com as vozes da Casa. Por duas vezes também, temos a representação do povo por pessoalização e indeterminação (pessoas de bem, aqueles que sem partidarizar estão indo às ruas).

"Meus cumprimentos àqueles que, ordeiramente, sem partidarizar a questão, estão indo às ruas para protestar contra essa 
série de desmandos e falsas promessas que estão ocorrendo no nosso País."

ANDRE VARGAS- PT (Presidente da Sessão em resposta ao Deputado Luis Carlos Heinze)

Em resposta ao pronunciamento do Deputado Luis Carlos Heinze, o Presidente da sessão, Deputado André Vargas, utiliza de modalização ("sem polemizar", "só") por duas vezes. Nesses casos, o orador é o Experienciador que deseja falar algo, mas usa, como diversas vezes visto, o processo mental desiderativo para não falar diretamente (em lugar de "aviso", usa "quero só avisar, por exemplo).

"Deputado Luis Carlos Heinze, sem polemizar, quero só avisar que acompanhei as manifestações". "Sem polemizar, quero só levantar que nós precisamos ter muito cuidado em relação a isso".

Manifestação aparece como existente por duas vezes e debate por uma, assim, não há inclusão dos manifestantes de forma ativa.

"Houve manifestação contra a Rede Globo, houve manifestação a favor dos indígenas, há o debate sobre a questão dos direitos humanos".

\section{JOSÉ HUMBERTO (Bloco/PHS-MG)}

O orador modaliza usando "talvez" por três vezes no primeiro excerto. Demonstra a perplexidade dos políticos diante dos protestos.

"O que talvez a gente não esperasse ou a maioria não esperasse é que a força dessas manifestações talvez tenha assustado a Nação brasileira, e talvez, sobretudo a classe política".

Há predominância de processos relacionais, usados para caracterizar e identificar. Dessa maneira, vemos a busca do parlamentar em explicar o que está acontecendo. 
Os manifestantes são representados como "manifestações", "população" e "povo", de maneira impessoal, por assimilação e coletivização.

Há diferenciação no contraponto entre "nós", os políticos, e o povo que espera algo. Há modulação, o parlamentar exprime a obrigação de os políticos construírem um novo Brasil, eles são os Atores, enquanto o povo é o Beneficiário. "Nós temos que construir esse Brasil e é esse Brasil, é essa nação que o povo espera de nós".

A utilização de "nós" e "nossos" aproxima o orador de seus pares, como podemos ver em: "A população não se sente representada e nós aqui temos dificuldade de fazer valer os nossos mandatos".

\section{DR. CARLOS ALBERTO (PMN-RJ)}

O parlamentar utiliza processos mentais perceptivos e cognitivos tendo ele próprio como Experienciador e o povo como Fenômeno. Sua fala é, assim, o relato de sua percepção do movimento. "Leio nos jornais, nas revistas e vejo nas tevês que muitos estão surpresos com os movimentos recentes...". "Vi um jovem, em São Paulo, dizer que a necessidade de redução dos preços das passagens foi o estopim para que esses movimentos fossem deflagrados".

As manifestações surgem como Portador e o termo sociedade ocorre por três vezes inserido na Circunstância. Há uma caracterização do movimento como justo e democrático e dos políticos como cegos e surdos.

"As manifestações recém-ocorridas, excetuados os desmandos provocados por aqueles que querem se aproveitar politicamente desses momentos, que não concordo, e que não são objeto da maioria, que quer ver e sentir um novo caminho para o nosso País, são justas, democráticas e decorrem do saturamento da sociedade, porque estamos cegos e surdos". 
O discurso, portanto, traz a percepção e caracterização dos protestos e a necessidade (obrigação) de os políticos ascultarem o povo, ou seja, inquirirem, escutarem:

"Precisamos ouvir o povo".

“... não podemos agir como se fôssemos os donos da verdade, sem auscultar os reclamos da sociedade brasileira, as suas necessidades básicas, as suas carências, os seus anseios."

\section{EDUARDO SCIARRA (PSD-PR. Como Líder)}

O orador se refere, de início, às manifestações como: "isso que tem surpreendido a toda a sociedade brasileira, essa movimentação das ruas, essa insatisfação, essas mobilizações pelo Brasil afora". Atribui os motivos do protesto a uma insatisfação não específica, como verificamos nos excertos abaixo:

"uma insatisfação generalizada com relação aos rumos não necessariamente da classe política, mas do Poder constituído; insatisfação, enfim, com o rumo que muitas coisas têm tomado em nosso País."

"Mas, com toda a certeza, já antecipadamente dava para se dizer que aquela era uma manifestação silenciosa da população com relação a rumos que não estavam sendo entendidos como corretos pela população."

"Eu quero deixar aqui esta constatação e dizer que, com toda a certeza, essa mobilização das ruas deve ser entendida como uma manifestação de insatisfação".

Há muita modalização nesse discurso, o orador utiliza “com toda a certeza" por três vezes e "sem dúvida nenhuma" uma vez. "Essa reflexão, com toda a certeza, não pode ser fruto do calor do momento".

"É uma reflexão que tem de ser estudada, tem de ser analisada, $e$, essas ações para responder à sociedade têm de ser praticadas com 
toda a transparência, porque isso, sem dúvida nenhuma, é o que a sociedade tem nos cobrado".

Além disso, há modulação por obrigação por três vezes quando ele utiliza a expressão "tem de", falando do que os políticos devem fazer em relação aos protestos, primeiro com dois processos mentais cognitivos (estudar, analisar) e depois com a ação representada pelo processo material (praticar). E por último, a expressão "deve ser" mais uma vez exprimindo obrigação.

Há quatro ocorrências de processos verbais, sendo a sociedade o Dizente por uma vez e nas outras o próprio orador ou um dizente indeterminado. Mais uma vez temos os processos relacionais caracterizando as manifestações e a pouca utilização de processos materiais, revela pouca ação. Os processos mentais mostram a reflexão interna ainda sem resultado prático nas ações dos governantes.

\section{EURICO JÚNIOR (PV-RJ)}

Nesse discurso, encontramos algumas nomeações, que são representações especifícas que tratam o ator social de forma determinada com a sua identidade única. Primeiro Ulysses Guimarães é lembrado como Dizente, por último três deputados são citados: Antonio Vacarezza e José Guimarães são chamados pelo último nome e Andre Vargas pelo nome e função na Câmara. Esses três aparecem como Beneficiários, a conduta deles é elogiada.

"Se durante as manifestações que aconteceram ontem por todo o Brasil o Dr. Ulysses, aí estivesse, diria que temos de ouvir o clamor das ruas".

"Queria registrar isso, que é muito importante. E parabenizar a atitude não só do Vaccarezza, do Guimarães e também do nosso VicePresidente Andre Vargas, que soube conduzir muito bem o movimento ontem". 
A polícia militar também recebe elogios junto com os manifestantes, no entanto, esses aparecem como meta e complemento, enquanto aqueles como Ator e Sujeito: “A PM, ontem, deu uma aula de democracia, junto com os manifestantes". Isso quer dizer que à polícia foi dado um papel de ação enquanto os manifestantes foram colocados em posição passiva.

\section{MENDONÇA FILHO (DEM-PE. Como Líder)}

Nos excertos analisados do discurso desse deputado, o povo aparece como Fenômeno e Atributo principalmente, pois há predominância de processos mentais e relacionais. Os vocábulos escolhidos pelo parlamentar para designar o povo são: a chamada voz rouca das ruas (Fenômeno), sociedade brasileira (Atributo), grande e importante manifestação (Atributo), sociedade (Fenômeno e Beneficiário), povo (Experienciador e Ator), revolta popular (Existente) e a voz do povo (Fenômeno).

Nessa fala Brasil e voz rouca das ruas vêm dissociados, um é Experienciador e outro Fenômeno: "o Brasil ontem ouviu literalmente a chamada voz rouca das ruas." Apesar de já terem ocorrido outros protestos, o adjunto de modo "ontem" mostra que o orador se refere aos protestos do dia anterior, talvez porque no dia 17 de junho de 2013, os protestos tenham chegado tão próximos ao Congresso Nacional. Ele se refere a "chamada voz rouca das ruas". Chamada por quem? A voz das ruas já estaria rouca, segundo o deputado. Brasil aí, diferente do que foi visto em outras falas, não se confunde com manifestantes.

O conflito entre manifestantes e governo é representado pela figura do divórcio na fala do parlamentar: "o poder público anda literalmente divorciado da sociedade brasileira". O governo é incluído por impessoalização e abstração, ou seja, não é representado pela figura de um político ou governante, mas de forma abstrata como "poder público". 
Há nomeação com formalidade do Deputado Andre Vargas, Presidente da Câmara em exercício no dia do protesto, e avaliação da manifestação como grande e importante. O político foi incluído por ativação (Portador) e a manifestação por passivação (Atributo).

"O Deputado Andre Vargas, teve conduta irrepreensível, do ponto de vista do comportamento, na recepção à grande e importante manifestação de frente ao Congresso Nacional".

No excerto "Quem vive o dia a dia do povo percebe claramente a distância entre a realidade da propaganda, entre a realidade do discurso e a realidade do povo", é possível notar que o Adjunto de Comentário "claramente" revela a opinião do parlamentar de que o motivo das manifestações estaria claro para todos. Há indeterminação quando o orador escolhe como Sujeito "quem vive o dia a dia do povo". Esse alguém perceberia de forma clara o motivo dos protestos populares $\mathrm{O}$ orador fala ainda em três realidades, a da propaganda, a do discurso e a do povo. A distância mencionada entre elas seria a distância entre o que é prometido pelos políticos e o que é cumprido.

O vocativo "minha gente" na fala "É por tudo isso, minha gente, que o povo vai às ruas" revela diferenciação do interlocutor e do povo que protesta. O parlamentar fala como alguém de fora da situação. O povo nesse excerto é Ator, vai às ruas. Cabe, no entanto, aos políticos "ouvir" e "oferecer" resposta a sociedade, que aparece como Beneficiária da ação: "A gente tem que ouvir a voz do povo e oferecer a resposta correta à sociedade, fazendo com que se mude a agenda".

Do mesmo modo como observado em outros discursos, encontramos o povo como Experienciador de processo mental desiderativo, ou seja, é o povo que quer e o governo que faz ou pode fazer: "É evidente que o povo quer sempre mais". A metáfora interpessoal "é evidente" revela o forte comprometimento do orador com o que é dito. 


\section{ARNALDO JORDY (PPS-PA. Como Líder)}

O líder do PPS, partido de oposição ao governo representa o povo nesse discurso, inicialmente, de forma impessoal e abstrata. O orador utiliza metáfora e nominalização para se referir aos manifestantes: "eu queria festejar essa onda democrática, essa manifestação cívica da sociedade brasileira, da juventude brasileira”.

Há exclusão por supressão em "Eu lamento a falta de reflexão diante dessas manifestações", pois a nominalização omite quem deixou de refletir.

O povo é Sujeito apenas uma vez, como dizente, sentença em que o parlamentar usa o adjunto de comentário "com razão" para concordar e se aproximar do povo "E $a$ população, com razão, começa a questionar essas obras farâ̂nicas, enquanto a agenda básica da sociedade está sobrestada". O adjetivo "sobrestada" exclui participante, uma vez que encobre os responsáveis pela suspensão da agenda ou pauta que é de interesse da sociedade.

O parlamentar modaliza, diminui o grau de certeza, ao tratar do que a Câmara deve fazer em resposta aos movimentos de protesto, ele usa "eu acho":

"Acho que esta Casa, esta Câmara dos Deputados precisa imediatamente associar-se ao povo brasileiro nessas reclamações lícitas que ele está levando às ruas."

“...acho que além da Comissão Geral, que foi sugerida na reunião de Líderes para quarta-feira, para ouvirmos os reclamos da sociedade, precisamos também estabelecer uma agenda mínima."

\section{CARLOS SAMPAIO (PSDB-SP. Como Líder)}

Nesse discurso, o parlamentar usa o termo "nação" várias vezes para se referir ao povo, ao país, por isso as sentenças selecionadas para análise contêm movimento e nação principalmente. 
O orador faz uso de repetição para enfatizar o que diz: "Este é um movimento em que pese difuso, este é um movimento em que pese disperso, este é um movimento sem dúvida de indignação".

Há predominância de processos relacionais e mentais cognitivos. Os relacionais trazem a definição do movimento, que aparece como atributo. Já os mentais cognitivos trazem os políticos como experienciadores refletindo sobre o que estava acontecendo. Aliás, mesmo quando usa o processo verbal, no último excerto, o parlamentar está chamando os colegas para um momento de reflexão:

"Eu clamo aos colegas Parlamentares: façamos um momento de reflexão para sabermos de nossos próprios erros e, a partir de agora, andemos em consonância com o sentimento da Nação".

O povo é representado de forma impessoal e abstrata: "sentimento da nação", "anseios da nação". "Existe um sentimento da Nação, e este sentimento da Nação cabe a nós como Parlamentares percebê-lo."

Há também exclusão por supressão e por encobrimento, quando o orador fala de indignação generalizada e da "visão que têm da gente": "Nós só mudaremos a visão que têm da gente com postura, postura política, com decisão acertada, e que corresponda aos anseios da Nação".

Apesar de ser líder do PSDB, partido de oposição ao governo, o deputado colocase como alvo dos protestos, afirmando que eles não se dirigem apenas ao governo federal, conforme explicitado a seguir:

"O movimento é de indignação geral contra todos e contra toda a classe política."

"Srs., se continuarmos achando que esses movimentos são contra o Governo do Estado A ou B (palmas nas galerias) ou contra o Governo Federal, nós vamos estar colocando uma venda em nossos olhos e não estaremos a perceber que a indignação é generalizada e estamos todos na vala comum." 


\section{NILSON LEITÃO (PSDB-MT. Como Líder da Minoria)}

O líder da Minoria começa seu discurso respondendo a fala de parlamentares que o precederam na tribuna. Inicialmente, ele contrapõe a fala de outra deputada. A polaridade negativa, vista no segundo excerto, é usada para refutar o que foi dito pela líder do PC do B: "Não é susto o que a população está vivendo, é impaciência, indignação pela irresponsabilidade do Governo". Antes ele havia falado: "Eu também ouvi da deputada, Líder do Pc do B, dizendo que foi a Polícia de São Paulo que assustou a população e que, graças a isso, cresceu esse movimento nas ruas".

A polaridade negativa vem para revelar na fala do deputado tudo aquilo que ele acredita que o Governo deveria ter feito, mas não fez : “Ele (o movimento) é contra aquele que não aplica direito o dinheiro do povo, que não aplica o recurso público, é contra aquele que não sabe o que está fazendo no poder". "O Governo brasileiro não conseguiu ter rumo, não conseguiu ter um projeto onde efetivamente melhore a vida da população".

A Modulação de obrigação aparece para apontar o que o Governo tem que executar agora: "O Governo brasileiro tem que ter autocrítica, humildade de entender que o Brasil chegou num momento em que não aguenta mais".

Em "A voz das ruas, essa voz do povo, que o PT tanto proclamou no passado,

precisa ser defendida agora" temos, mais uma vez a modulação de obrigação. O povo é representado como beneficiário e não fica claro quem deve defendê-lo e de quem.

Por fim, o orador conclui seu discurso com uma ordem aos governantes : "Ouçam esse povo e façam um governo decente".

\subsection{Resultados e Discussão}

Como resultado das análises e, retomando as questões de pesquisa expostas no Capítulo 3, verificamos que o povo é representado de maneira impessoal e não específica, não há citação do nome de nenhum manifestante, por exemplo. É representado como grupo em geral, no máximo há referência ao fato de a maioria ser jovem ou de supostamente 
pertecerem a determinada classe social (Agora, Sr. Presidente, o que é esse movimento de classe média? [6] ) Metonímias como "a voz das ruas" e "as ruas" são utilizadas para designar a população (Queremos sim fazer uma pauta consonante com a voz das ruas [1]).

Os termos que designam o povo ocupam, principalmente, o papel de Meta ou Beneficiário, significando dizer que são aqueles que recebem algo de alguém. Ocorrem também como Experienciadores, uma vez que são retratados como aqueles que querem alguma coisa. Poucas vezes, aparecem como Ator, papel exercido, mormente pelos parlamentares, configurando-se como aqueles que podem agir, como pode ser observado nos exemplos abaixo.

\begin{tabular}{|l|l|l|l|l|}
\hline & E esta Casa & tem que & construir & $\begin{array}{l}\text { uma outra agenda, para } \\
\text { podermos dar vazão a essas } \\
\text { manifestações ocorridas no } \\
\text { Brasil afora. }\end{array}$ \\
\hline Transitividade & Ator & & $\begin{array}{l}\text { Proc. Material } \\
\text { Criativo }\end{array}$ & Meta \\
\hline
\end{tabular}

\begin{tabular}{|l|l|l|l|l|l|}
\hline & Infelizmente, & $\begin{array}{l}\text { o que nós } \\
\text { fazemos e o que } \\
\text { temos feito }\end{array}$ & não mais & atende & $\begin{array}{l}\text { ao que essa } \\
\text { sociedade quer. }\end{array}$ \\
\hline Transitividade & & Ator & & $\begin{array}{l}\text { Proc. } \\
\text { Material }\end{array}$ & Meta \\
\hline
\end{tabular}




\begin{tabular}{|l|l|l|l|l|}
\hline & $\begin{array}{l}\text { É a juventude } \\
\text { do Brasil, que }\end{array}$ & agora & quer & $\begin{array}{l}\text { construir uma outra } \\
\text { agenda. }\end{array}$ \\
\hline Transitividade & Experienciador & & $\begin{array}{l}\text { Proc. Mental } \\
\text { Desiderativo }\end{array}$ & Fenômeno \\
\hline
\end{tabular}

Os políticos surgem, igualmente, como Experienciadores, pois são também aqueles que pensam, percebem e ouvem as demandas dos manifestantes.

\begin{tabular}{|l|l|l|l|l|}
\hline & Quem de nós, & verdadeiramente, & $\begin{array}{l}\text { supunha, } \\
\text { pensava, } \\
\text { acreditava }\end{array}$ & $\begin{array}{l}\text { que pudesse haver no } \\
\text { Brasil tamanha } \\
\text { insatisfação? }\end{array}$ \\
\hline Transitividade & Experienciador & & $\begin{array}{l}\text { Proc. Mental } \\
\text { Cognitivo }\end{array}$ & Fenômeno \\
\hline
\end{tabular}

Além disso, com relação aos significados trazidos pela Metafunção Ideacional, a constatação de que há predominância de processos mentais e relacionais demonstra a expressão do desejo dos manifestantes percebida pelos parlamentares e a tentativa desses de definir os protestos. Uma vez que o povo e as manifestações aparecem diversas vezes como Atributo, Portador e Identificado, participantes dos processos relacionais, vemos as afirmações dos deputados caracterizando o movimento. A utilização de processos mentais desiderativos revela o querer da população e dos mentais perceptivos (ouvir, perceber) mostra a reflexão dos políticos sobre os protestos.

Há nomeação de vários políticos, trazendo destaque, dessa forma, a essas pessoas. ("Queria registrar isso, que é muito importante. E parabenizar a atitude não só do Vaccarezza, do Guimarães e também do nosso Vice-Presidente Andre Vargas, que soube conduzir muito bem o movimento ontem") [15]. 
Quanto à posição de Sujeito, na Metafunção Interpessoal, vimos que termos ligados ao povo ("manifestações", "movimento, "pessoas", "sociedade”) ocuparam esse lugar, assim como expressões afins aos políticos ("nosso governo", "nossa bancada", "nós”, “a gente”, “esta Casa”). Segundo Halliday (2014), a escolha do Sujeito é motivada semanticamente, pois sobre ele recai a validade da informação, o falante atribui a esse item o ponto de apoio do argumento (HAWAD, 2002, p.145). Nas análises, pude observar que tanto o povo como o governo são postos como Sujeito de maneira equilibrada, os oradores não priorizaram nem um nem outro para esse papel. Por outro lado, sabendo que o item que ocorre como Sujeito é ao mesmo tempo Ator ou Experienciador ou Portador ou Identificado; vejo que a posição daquele que age (Ator) incidiu mais vezes sobre os termos referentes aos governantes, enquanto ao povo coube a posição daquele que sente, deseja (Experienciador), tem ou é (Portador, Identificado).

Quanto ao uso de modalidade, encontramos muitas ocorrências conforme descrito neste capítulo. Os congressistas usam, muitas vezes, o verbo "querer" para tornar seu falar menos direto. Usam de repetições com a finalidade de dar ênfase a algo que estão dizendo. O sentido de obrigação está presente diversas vezes com expressões como "é preciso", "deve", falando da necessidade de os governantes ouvirem o que a população reivindica. ("Ouvir as vozes das ruas é dever de todos os poderes" [3], "Nós temos que perguntar a essa sociedade, através do plebiscito, o que ela quer fazer, dentro dos temas que nós temos que discutir" [4], “Os políticos, os Governos, todos que representam o setor público precisam ouvir a sociedade"'[5].

A expressão "parece que" também é usada e demonstra incerteza, ao mesmo tempo em que alguns oradores repetem "com certeza" ou "sem dúvida alguma" excessivamente e acabam por suscitar desconfiança (A sociedade parece que está dizendo que quer ir para a democracia participativa [10], "Mas, com toda a certeza, já antecipadamente dava para se dizer que aquela era uma manifestação silenciosa da população com relação a rumos que não estavam sendo entendidos como corretos pela população" [14]). 
Os parlamentares da base do governo procuram se colocar do lado do povo, no sentido de se mostrarem, em sua maioria, favoráveis aos seus pleitos e direito de manifestação. Relembram sua história de lutas sociais e protestos nas ruas de forma a se identificarem com os manifestantes ("O povo na rua é nossa história” [3], "Quero dizer que temos de constituir uma pauta adequada para abraçar este momento de mobilização das ruas, de onde nós saímos" [1]).

Já os deputados de oposição aparecem mais distanciados do povo, eles percebem que a indignação popular é generalizada e conclamam seus pares a ouvir e atender à população. Reconhecem o distanciamento entre o que é prometido em campanha eleitoral e a realidade oferecida à sociedade. Eles veem o governo divorciado do povo e propõe um entendimento entre o que é cobrado nas ruas e o que posto em prática no Congresso. (“ $o$ poder público anda literalmente divorciado da sociedade brasileira" [5], Quem vive o dia a dia do povo percebe claramente a distância entre a realidade da propaganda, entre a realidade do discurso e a realidade do povo. [5], Acho que esta Casa, esta Câmara dos Deputados precisa imediatamente associar-se ao povo brasileiro nessas reclamações lícitas que ele está levando às ruas [7]). Diferentemente, dos outros parlamentares de oposição, o líder da minoria faz duras críticas ao governo e lê o movimento como dirigido aos políticos de situação ("Não é susto o que a população está vivendo, é impaciência, indignação pela irresponsabilidade do Governo" [16], "Ouçam esse povo e façam um governo decente" [16]).

Quanto às exclusões de atores sociais abordadas tanto por Fairclough (2003) quanto por van Leeuwen (2008), vi que a população, muitas vezes, foi mencionada em termos de localização, ou seja, de forma metonímica, como "Brasil”, "ruas", "voz das ruas", ("o Brasil chegou num momento em que não aguenta mais" [16]), como também com o uso de numerais (“Os milhares de manifestantes”). Dessa maneira, a população que foi às ruas protestar foi representada de forma generalizada. Atores sociais como a polícia e a imprensa, por diversas vezes, foram excluídos por supressão total, não sendo mencionados nenhuma vez em alguns discursos. Isso revela as escolhas do falante, mostram aquilo que cada orador decidiu focar ou tirar de foco. Assim, alguns mencionam a 
reação da Presidente da República ("A minha primeira frase está em sintonia com a nossa Presidenta Dilma, que hoje pela manhã expressou o seu apoio, como não poderia deixar de ser, a manifestações." [2]), outros falam dos protestos dirigidos a emissora de televisão (Ontem o povo dizia: "Fora, Rede Globo"[10]), outros ainda abordam as matérias que devem ser postas em pauta no plenário da Câmara (“É por tudo isso, minha gente, que o povo vai às ruas, por conta da PEC 37, do descaso daqueles que representam o Governo" $[2]$.

Para concluir, retomo o arcabouço proposto por Chouliaraki e Fairclough (1999), a fim de expor uma sequência de análises utilizada por mim para atingir o objetivo desta pesquisa:

- Problema:

Observar como o povo é representado nos discursos parlamentares sobre manifestações.

- Obstáculos a serem resolvidos:

- Análise da conjuntura:

Os discursos analisados foram proferidos no dia 18/06/2013, um dia após uma grande manifestação em que houve tentativa de invasão do Congresso Nacional. Sabemos que o deputado, ao falar, dirige-se aos seus pares e principalmente à sociedade, que aguarda uma reposta do parlamento.

- Análise da prática em foco (em que o discurso é um momento)

O discurso parlamentar traz o posicionamento do seu partido quando ele fala como líder. É, também, uma resposta a seus eleitores e reflete a maneira como o Poder Legislativo se comporta diante do clamor da população. Além disso, tem poder de decisão, poder de convencer seus pares a rejeitar ou aprovar uma proposição. O líder faz uso da palavra também para orientar sua bancada no momento de uma votação. Como exemplo de proposições postas em discussão no período das manifestações, temos PEC 37, que retirava o poder de investigação do Ministério Público. Tal proposta foi colocada em votação 
poucos dias após os protestos nas ruas e foi rejeitada. Além dela, sabemos que os deputados aprovaram a redução do PIS-Cofins na tarifa de transporte público e a destinação de $25 \%$ dos royalties do petróleo para a saúde e $75 \%$ para a educação. Tais ações vieram em resposta a algumas das reivindicações populares.

- Análise do Discurso:

- Análise estrutural: a ordem do discurso (o discurso é transformativo e reprodutivo?)

Os discursos analisados nesta pesquisa reproduzem as relações de poder entre os políticos e o povo. Revelam a fala de quem tem o poder de decidir o que entra na pauta de votação, do que é prioridade e o que não é. O povo conseguiu ser ouvido quando se mobilizou aos milhares e protestou continuamente por semanas. O discurso mantém os significados de mundo nas relações de poder.

- Análise interacional:

- Análise interdiscursiva: há resposta de um deputado para outro, há citação de parte do discurso da Presidente da República e menção a fala de uma ministra. No primeiro caso, temos o líder da minoria contrapondo o discurso da líder do PC do B, partido da base do governo. No segundo, dois deputados do PT fazem referência ao discurso da Presidente, associando-se ao que ela disse. E por último, o líder da minoria menciona algo que uma ministra disse para em seguida criticar a ela e ao governo do PT.

- Análise linguística e semiótica: utilizei as Metafunções Ideacional e Interpessoal da LSF e as classificações dos atores sociais propostas por van Leeuwen para verificar como o povo foi representado nos discursos.

3) Função do problema na prática

Desvelar a forma como o povo é representado na fala dos congressistas pode trazer uma consciência do comportamento e intenções desses mandatários em relação ao que propõem 
e votam, uma vez que suas falas demonstram suas prioridades e os valores que baseiam suas decisões no parlamento.

4) Possíveis formas de vencer os obstáculos

Realizar análise linguística e semiótica dos discursos selecionados a fim de perceber de que maneira o povo foi representado.

5) Reflexões sobre a análise:

Os resultados da pesquisa devem gerar uma consciência crítica no cidadão que assiste ao seu Deputado discursar e votar nas sessões legislativas. É necessário que a população fiscalize os debates e atos que têm lugar no Congresso Nacional e não se deixem iludir por promessas, mas acompanhem se as palavras vêm acompanhadas de ações. 


\section{Capítulo 5}

\section{Considerações Finais}

A combinação da autonomia propiciada pelos novos meios de comunicação com a indignação diante de serviços públicos prestados de forma inadequada ou precária gerou nos cidadãos brasileiros o descontentamento que se traduziu em protestos que questionaram a função de representantes do povo dos governantes tanto do Poder Executivo quanto do Legislativo. O povo foi às ruas pressionar os políticos a fim de ver suas reivindicações atendidas, seu sofrimento mitigado por meio da ação daqueles que foram eleitos para administrar, fiscalizar e proporcionar melhorias para a coletividade.

A profunda desconfiança nas instituições políticas além da crise de legitimidade dos representantes do povo, mencionadas por Castells (2012), foram sentidas nas manifestações de 2013. Contudo, a disposição dos parlamentares em ouvir as reclamações da população e colocar algumas de suas solicitações em pauta gerou decisões que de alguma forma beneficiaram a população, ainda que momentaneamente. Além do mais, apesar de os partidos políticos serem considerados essenciais para o governo popular, a ausência de bandeiras de partidos políticos nas manifestações revela a descrença e frustração do povo com a maneira como a política estava sendo conduzida no Brasil. Os protestos expuseram uma quebra de confiança do povo em relação aos seus governantes e os discursos aqui analisados mostraram isso ao trazer a fala de parlamentares que confessavam suas falhas em ouvir a população e legislar e decidir de acordo com os interesses de seus eleitores.

O povo exerceu ali seu direito de fiscalizar e cobrar o cumprimento de promessas feitas por seus eleitos e estes com o desejo de continuarem no poder, muitas vezes temem contrariar a vontade de quem os elegeu. Os oradores na tribuna buscavam assim apaziguar sua audiência com a demonstração de compreensão de suas queixas e a disposição em agir para atendimento de sua pauta. Afinal, conforme explica Charaudeau (2006), em situações 
de protesto, meras palavras não são suficientes para acalmar a população, mas devem vir acompanhadas de ação. Nesse aspecto, Fairclough e Fairclough (2012) afirmam que em política as questões e debates existem para fundamentar ações e que a representação deve ser estudada, observando-se a questão da ação. Por isso, além de desvelar a representação do povo e dos próprios políticos por meio dos discursos analisados nesta pesquisa, achei por bem incluir informações sobre que ações foram tomadas pelo Congresso no período das manifestações. Incluo abaixo uma tabela com alguns resultados dos protestos:

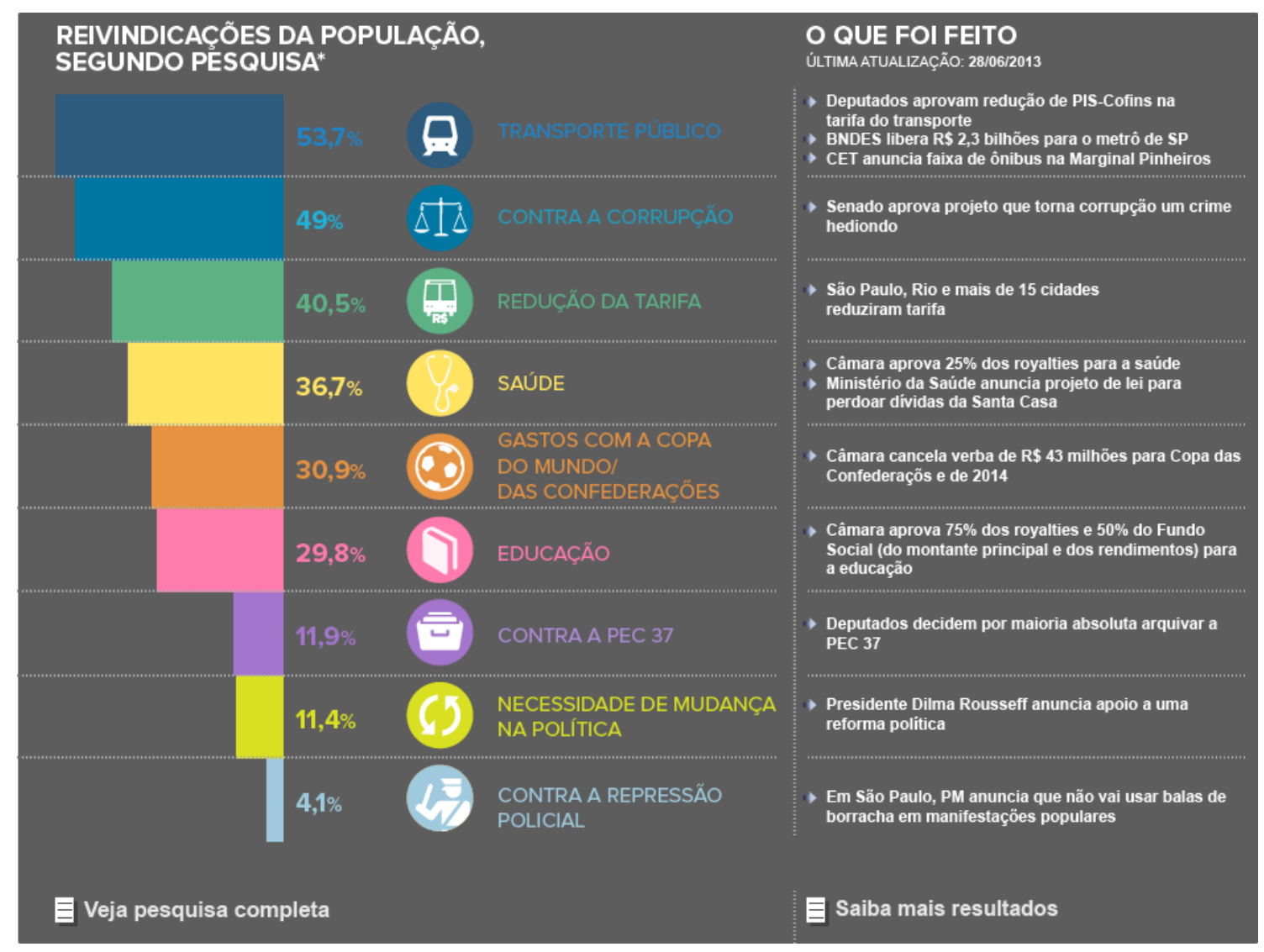

Figura 5-O que foi feito.

Fonte: http://g1.globo.com/brasil/linha-tempo-manifestacoes-2013/platb/

Bauman (1999, p. 2) defende uma reinvenção política em que a sociedade civil possa agir coletivamente por meio de instituições, trazendo para esfera pública os problemas que ela crê mereçam ser discutidos. Para ele, deve haver uma deliberação coletiva. Quanto a isso, vemos que no Brasil houve por parte da Presidente da República a sugestão da realização de um plebiscito a fim de que a população fosse consultada sobre os 
rumos de uma reforma política. Contudo, essa consulta acabou não acontecendo.

A avaliação geral dos protestos, por meio dos discursos dos líderes partidários aqui estudados, é que houve um momento de perplexidade geral, tanto de parlamentares da situação como de oposição, diante das manifestações. E que essas mobilizações produziram sim frutos de reflexão, debate e ação política. Com o passar do tempo, no entanto, com a chegada do mundial de futebol, esses movimentos de protestos reduziram-se. Outras manifestações aconteceram, inclusive em 2015, mas, diferentemente de 2013, onde os protestos eram dirigidos aos governantes de maneira geral, os deste ano direcionaram-se principalmente ao Governo Federal.

Todavia, muitos cidadãos têm demonstrado interesse em acompanhar votações no Congresso Nacional e outras decisões políticas, seja no Legislativo, Executivo ou Judiciário e, mobilizações têm ocorrido presencialmente ou por meio de abaixo-assinados pela internet. A fiscalização se os discursos têm sido acompanhados de ações e a reflexão se os discursos têm traduzido os desejos e necessidades da população precisam fazer parte da vida dos cidadãos. 


\section{Referências}

ALMEIDA, F. S. D. P. A avaliação na linguagem. Os elementos de atitude no discurso do professor - um exercício em Análise do Discurso Sistêmico-Funcional. São Carlos: Pedro \& João Editores, 2010.

AZAMBUJA, Darcy. Introdução à Ciência Política. São Paulo: Globo, 2008.

Anthony, L. (2014). AntConc (Version 3.4.3) [Computer Software]. Tokyo, Japan: Waseda University. Available from http://www.laurenceanthony.net/

BARBARA, L. MACÊDO, C. M.M. "Linguística Sistêmico-Funcional para Análise do Discurso um Panorama Introdutório". In: Cadernos de Linguagem e Sociedade, 10, 2009. pp. $89-107$.

BAUER, M. \& GASKELL. Pesquisa qualitativa com texto, imagem e som: um manual prático. Trad. de Pedrinho A. Guareschi. Petrópolis: Vozes, 2002.

BAUMAN, Zygmunt. Globalização: As conseqüências humanas. Rio de Janeiro: Jorge Zahar Editor, 1999.

Modernidade Líquida. Rio de Janeiro, Jorge Zahar, 2001.

BRASIL. Congresso Nacional. Câmara dos Deputados. Regimento Interno da Câmara dos Deputados, Brasília: Edições Câmara, 2015.

BUTT et. al. Using functional grammar: an explorer's guide. 2. ed., Sidney: Macquarie University, 2003. 
CASTELLS, Manuel. Redes de indignação e esperança: movimentos sociais na era da Internet. Trad. de Carlos Alberto Medeiros. Rio de Janeiro: Jorge Zahar, 2013.

CHARAUDEAU, Patrick. Discurso Político. São Paulo. Editora Contexto, 2006.

CHOULIARAKI, L. \& FAIRCLOUGH, N. Discourse in late modernity. Edinburgh: Edingurgh University Press, 1999.

EGGINS, Suzanne. An Introduction to Systemic Functional Linguistics. London: Continuum International Publishing Group, 2004.

FAIRCLOUGH, N. Analysing discourse: textual analysis for social research.

London: Routledge, 2003.

. Discurso e mudança social. Trad. I. Magalhães. Brasília: Editora Universidade de Brasília, 2001.

; FAIRCLOUGH, Isabela. Political Discourse Analysis. New York, Routledge, 2012.

FERRARI, Elir. A Representação dos Atores Sociais e a Imagem da Mulher em Contos de Marina Colasanti. In: BERNARDO, Sandra; VELOZO, Naira de Almeida; MARTINS, Queila de Castro. Linguagem: Teoria, Análise e Aplicações (V). Rio de Janeiro: Programa de Pós-Graduação em Letras - ILE/UERJ, 2010, p. 6-17.

FLICK, U. Uma introdução à pesquisa qualitativa. Tradução de Sandra Netz. 2. ed. Porto Alegre: Bookman, 2004.

FUZER, Cristiane; CABRAL, Sara Regina Scotta. Introdução à gramática sistêmicofuncional em língua portuguesa. Santa Maria: Universidade Federal de Santa Maria, Centro 
de Artes e Letras, Departamento de Letras Vernáculas, Núcleo de Estudos em Língua Portuguesa, 2010.

GHIO, E. \& FERNÁNDEZ, M.L. (2005). Manual de Linguística Sistémico Funcional, 1a ed. Santa Fé (Argentina): Univ. Nacional del Litoral.

GIDDENS, Anthony. As Consequências da Modernidade. São Paulo: Unesp, 1991.

HALLIDAY, Michael Alexander Kirkwood. Halliday's Introduction to Functional Grammar. 4th ed. revised by C. M. I. M. Matthiessen. New York, Routledge, 2014.

HAWAD, Helena Feres. Tema, Sujeito e Agente: A voz passiva portuguesa em perspectiva sistêmico-funcional. 2002. Tese (Doutorado em Letras) Pontifícia Universidade Católica do Rio de Janeiro: Rio de Janeiro, 2002.

LEEUWEN, Theo van. Discourse and practice : new tools for critical discourse analysis. New York, Oxford University Press, 2008.

LINHARES, Christiê Duarte. A Negação em Sentenças Judiciais sob a Perspectiva da Semântica Argumentativa. 2012, 86f. Dissertação (Mestrado em Letras) Faculdade de Letras da Pontifícia Universidade Católica do Rio Grande do Sul, Porto Alegre, 2012.

MARTIN, J. R. \& WHITE, P. R. R. The language of evaluation: appraisal in English. Londres: Palgrave Macmillan, 2005.

MARTIN, J.R.; MATTHIESSEN, Christian M.I.M.; PAINTER, Clare. Deploying Functional Grammar. Beijing: The Commercial Press, 2010.

MARTIN, J. R.; ROSE, David. Working with Discourse: Meaning beyond the clause. London, New York: Continuum, 2003. 
NEVES, Maria Helena de Moura. Texto e Gramática. São Paulo: Editora Contexto, 2006.

RESENDE, Viviane de Melo. Análise de Discurso Crítica: Uma perspectiva transdisciplinar entre a Linguística Sistêmico-Funcional e a Ciência Social Crítica, 33rd International Systemic Functional Congress, 2006.

RESENDE, V. M. \& RAMALHO, V. Análise de Discurso Crítica, do modelo tridimensional à articulação entre as práticas: implicações teórico-metodológicas. Linguagem em (Dis)curso, 5: 185- 207, 2004.

SILVA, Edna Cristina Muniz da. Do discurso à gramática: um enfoque crítico e funcional de gêneros. Cadernos de linguagem e sociedade. Volume 11 (2), 2010.

SILVA, Jackson Ronie Sá, ALMEIDA, Cristóvão Domingos, GUINDANI, Joel Felipe, Pesquisa Documental: pistas teóricas e metodológicas. Revista Brasileira de História \& Ciências Sociais, 2009.

SILVA, Lidiane Rodrigues Campêlo da, DAMACENO, Ana Daniella, MARTINS, Maria da Conceição Rodrigues, SOBRAL, Karine Martins, FARIAS, Isabel Maria Sabino de, Pesquisa Documental: Alternativa investigativa na formação docente. IX Congresso Nacional de Educação - EDUCERE, 2009.

TEIXEIRA, Enise Barth, A Análise de Dados na Pesquisa Científica - importância e desafios em estudos organizacionais. Desenvolvimento em Questão, Editora Unijuí: 177$201,2003$.

TORRES, Ana Paula Repolês. $O$ sentido da política em Hannah Arendt, Trans/Form/Ação, São Paulo, v.30(2), 2007, p.235-246.

THOMPSON, Geoff. Introducing Functional Grammar. $3^{\text {rd }}$ edition, London: 2004. 


\section{ANEXOS}

Quadro 8- Inclusão e Exclusão de Atores Sociais

\begin{tabular}{|c|c|c|c|c|c|}
\hline \multirow[t]{2}{*}{ Exclusão } & \multicolumn{5}{|l|}{ Supressão } \\
\hline & \multicolumn{5}{|l|}{ Encobrimento } \\
\hline & \multicolumn{5}{|l|}{ Ativação } \\
\hline & \multirow{4}{*}{ Passivação } & \multirow[t]{2}{*}{ Sujeição } & \multicolumn{3}{|l|}{ Associação } \\
\hline & & & \multicolumn{3}{|l|}{ Dissociaçao } \\
\hline & & Beneficiação & \multicolumn{3}{|l|}{ Diferenciação } \\
\hline & & & \multicolumn{3}{|l|}{ Indiferenciação } \\
\hline & \multicolumn{5}{|l|}{ Participação } \\
\hline & Circunstancial & & & & \\
\hline & Possessivação & & & & \\
\hline \multirow[t]{9}{*}{ Inclusão } & Pessoalização & Determinação & \multirow{6}{*}{ Categorização } & Funcionalização & \\
\hline & & & & \multirow{4}{*}{ Identificação } & Classificação \\
\hline & & & & & Identificação \\
\hline & & & & & Relacional \\
\hline & & & & & Id. Física \\
\hline & & & & \multicolumn{2}{|l|}{ Avaliação } \\
\hline & & & \multirow[t]{3}{*}{ Nomeação } & \multicolumn{2}{|l|}{ Formalização } \\
\hline & & & & \multicolumn{2}{|l|}{ Semiformalização } \\
\hline & & & & \multicolumn{2}{|l|}{ Informalização } \\
\hline
\end{tabular}




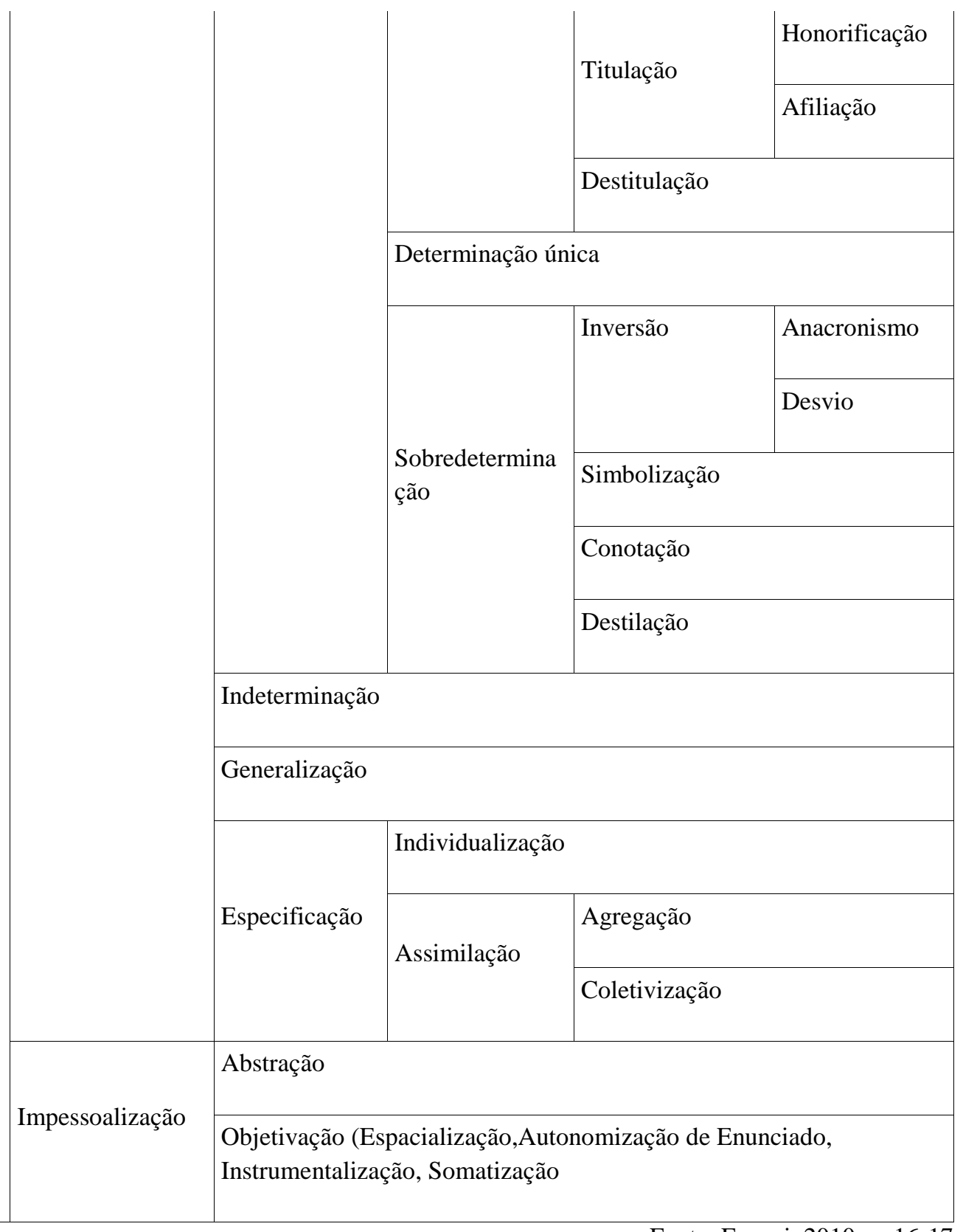

Fonte: Ferrari, 2010, p. 16-17 


\section{Descrições dos excertos dos discursos:}

\section{A SRA. ALICE PORTUGAL (PCdoB-BA. Como Líder)}

As manifestações que eclodiram País afora, inicialmente lastreadas na luta em defesa da não elevação dos preços das tarifas dos transportes, ganhou contornos difusos e espalhou-se pelo país.

\begin{tabular}{|c|c|c|c|c|c|c|}
\hline & $\begin{array}{l}\text { As manifestações que } \\
\text { eclodiram País afora, }\end{array}$ & $\begin{array}{l}\text { inicialmente } \\
\text { lastreadas na } \\
\text { luta em defesa } \\
\text { da não } \\
\text { elevação dos } \\
\text { preços das } \\
\text { tarifas dos } \\
\text { transportes, }\end{array}$ & ganhou & $\begin{array}{l}\text { contornos } \\
\text { difusos e }\end{array}$ & espalhou & $\begin{array}{l}\text { se pelo } \\
\text { país. }\end{array}$ \\
\hline Transitividade & Ator & Circunstância & $\begin{array}{l}\text { Proc. } \\
\text { Material }\end{array}$ & Meta & $\begin{array}{l}\text { Proc. } \\
\text { Material }\end{array}$ & $\begin{array}{l}\text { Circunst } \\
\text { ância }\end{array}$ \\
\hline $\begin{array}{l}\text { Sistema de } \\
\text { Modo }\end{array}$ & Sujeito & $\begin{array}{l}\text { Adj. } \\
\text { comentário }\end{array}$ & $\begin{array}{l}\text { Finito }+ \\
\text { Predicador }\end{array}$ & Complemento & $\begin{array}{l}\text { Finito }+ \\
\text { Predicador }\end{array}$ & Resíduo \\
\hline Ator Social & $\begin{array}{l}\text { Inclusão - ativação } \\
\text { Assimilação- } \\
\text { Coletivização }\end{array}$ & & & & & \\
\hline
\end{tabular}

É preciso, portanto, saudar as manifestações espontâneas e autênticas, mas, ao mesmo tempo, repudiar a agressão policial desmedida e também atitudes infiltradas que visam constituir vandalismos, contaminando as manifestações e agredindo o processo democrático.

\begin{tabular}{|l|l|l|l|}
\hline & $\begin{array}{l}\text { É preciso, } \\
\text { portanto, }\end{array}$ & saudar & $\begin{array}{l}\text { as manifestações espontâneas e } \\
\text { autênticas, }\end{array}$ \\
\hline
\end{tabular}




\begin{tabular}{|l|l|l|l|}
\hline Transitividade & & Proc. Verbal & alvo \\
\hline Sistema de Modo & $\begin{array}{l}\text { Modulação } \\
\text { obrigação }\end{array}$ & $\begin{array}{l}\text { Finito + } \\
\text { Predicador }\end{array}$ & Complemento \\
\hline Ator Social & & & Inclusão - passivação Assimilação \\
\hline
\end{tabular}

\begin{tabular}{|l|l|l|l|}
\hline & $\begin{array}{l}\text { mas, ao mesmo } \\
\text { tempo, }\end{array}$ & repudiar & $\begin{array}{l}\text { a agressão policial desmedida e também } \\
\text { atitudes infiltradas que visam constituir } \\
\text { vandalismos, contaminando as } \\
\text { manifestações e agredindo o processo } \\
\text { democrático. }\end{array}$ \\
\hline Transitividade & Circunstância & Proc. Verbal & Verbiagem \\
\hline Sistema de Modo & Adj. Modo & Finito + & Complemento \\
\hline Ator Social & & Predicador & \\
\hline
\end{tabular}

Em tempo, Presidente Biffi, parabenizo o Presidente em exercício da Casa, o Deputado Andre Vargas, que teve atitude serena, auspiciosa, de compreender a voz das ruas e não empreender uma repressão policial, como foi empreendida em outros lugares deste País.

\begin{tabular}{|l|l|l|l|l|}
\hline & Em tempo, & Presidente Biffi, & parabenizo & $\begin{array}{l}\text { o Presidente em } \\
\text { exercício da Casa, } \\
\text { o Deputado Andre } \\
\text { Vargas, }\end{array}$ \\
\hline Transitividade & & & Proc. Verbal & Alvo \\
\hline Sistema de Modo & & Vocativo & $\begin{array}{l}\text { Finito }+ \\
\text { Predicador }\end{array}$ & Resíduo \\
\hline
\end{tabular}




\begin{tabular}{|l|l|l|l|} 
Ator Social & $\mid \begin{array}{l}\text { Inclusão - } \\
\text { Pessoalização - } \\
\text { Nomeação - } \\
\text { Formalização }\end{array}$
\end{tabular} \mid$\quad \begin{aligned} & \text { Inclusão - } \\
& \text { Passivação - } \\
& \text { Beneficiação - } \\
& \text { Pessoalização - } \\
& \text { Nomeação - } \\
& \text { Formalização }\end{aligned}$

\begin{tabular}{|c|c|c|c|}
\hline & que & teve & $\begin{array}{l}\text { atitude serena, auspiciosa, de } \\
\text { compreender a voz das ruas_e não } \\
\text { empreender uma repressão policial, } \\
\text { como foi empreendida em outros } \\
\text { lugares deste País. }\end{array}$ \\
\hline Transitividade & Portador & $\begin{array}{l}\text { Proc. } \\
\text { Relacional }\end{array}$ & Atributo \\
\hline Sistema de Modo & Sujeito & $\begin{array}{l}\text { Finito + } \\
\text { Predicador }\end{array}$ & resíduo \\
\hline Ator Social & & & $\begin{array}{l}\text { Inclusão - Passivação - } \\
\text { Beneficiação - impessoalização - } \\
\text { objetivação - espacialização }\end{array}$ \\
\hline
\end{tabular}

Quero dizer que temos de constituir uma pauta adequada para abraçar este momento de mobilização das ruas, de onde nós saímos.

\begin{tabular}{|l|l|l|l|}
\hline & Quero & Dizer & $\begin{array}{l}\text { que temos de constituir uma pauta } \\
\text { adequada para abraçar este } \\
\text { momento de mobilização das ruas, } \\
\text { de onde nós saímos. }\end{array}$ \\
\hline Transitividade & $\begin{array}{l}\text { Proc. Mental } \\
\text { desiderativo }\end{array}$ & Proc. Verbal & Verbiagem \\
\hline Sistema de Modo & Finito & Predicador & Resíduo \\
\hline
\end{tabular}




\begin{tabular}{|l|l|l|} 
Ator Social & $\begin{array}{l}\text { Inclusão - Passivação - } \\
\text { Beneficiação - impessoalização - } \\
\text { objetivação - espacialização }\end{array}$ \\
\hline
\end{tabular}

Queremos sim fazer uma pauta consonante com a voz das ruas, mas, ao mesmo tempo, consagrando as vitórias adquiridas, porque elas não vieram de graça.

\begin{tabular}{|l|l|l|l|l|}
\hline & Queremos & Sim & fazer & $\begin{array}{l}\text { uma pauta consonante } \\
\text { com a voz das ruas, mas, } \\
\text { ao mesmo tempo, } \\
\text { consagrando as vitórias } \\
\text { adquiridas, porque elas } \\
\text { não vieram de graça. }\end{array}$ \\
\hline Transitividade & $\begin{array}{l}\text { Proc. Mental } \\
\text { desiderativo }\end{array}$ & & Proc. Material & Meta \\
\hline Sistema de Modo & Finito & Polaridade & Predicador & Resíduo \\
\hline Ator Social & & & & $\begin{array}{l}\text { Inclusão - Passivação - } \\
\text { Beneficiação - } \\
\text { impessoalização - } \\
\text { objetivação - } \\
\text { espacialização }\end{array}$ \\
\hline
\end{tabular}

\section{O SR. HENRIQUE FONTANA (PT-RS. Como Líder)}

A minha primeira frase está em sintonia com a nossa Presidenta Dilma, que hoje pela manhã expressou o seu apoio, como não poderia deixar de ser, a manifestações que, de forma pacífica, na sua ampla maioria, reivindicam mudanças ainda maiores no nosso País.

\begin{tabular}{|l|l|l|l|l|}
\hline & $\begin{array}{l}\text { A minha } \\
\text { primeira frase }\end{array}$ & Está & $\begin{array}{l}\text { em sintonia com a } \\
\text { nossa Presidenta }\end{array}$ & que hoje pela manhã \\
\hline
\end{tabular}




\begin{tabular}{|l|l|l|l|l|}
\hline & & & Dilma & \\
\hline Transitividade & Portador & $\begin{array}{l}\text { Proc. } \\
\text { Relacional }\end{array}$ & Atributo & Circunstância tempo \\
\hline Sistema de Modo & Sujeito & $\begin{array}{l}\text { Finito + } \\
\text { Predicador }\end{array}$ & Resíduo & Adj. Modo \\
\hline Ator Social & & & $\begin{array}{l}\text { Inclusão - } \\
\text { Pessoalização - } \\
\text { Nomeação }\end{array}$ & \\
\hline
\end{tabular}

\begin{tabular}{|l|l|l|l|l|}
\hline & expressou & o seu apoio, & $\begin{array}{l}\text { como não } \\
\text { poderia deixar } \\
\text { de ser, }\end{array}$ & $\begin{array}{l}\text { a manifestações que, de forma } \\
\text { pacífica, na sua ampla maioria, } \\
\text { reivindicam mudanças ainda } \\
\text { maiores no nosso País. }\end{array}$ \\
\hline Transitividade & Proc. Verbal & Verbiagem & & Alvo \\
\hline Sistema de Modo & $\begin{array}{l}\text { Finito + } \\
\text { Predicador }\end{array}$ & Complemento & $\begin{array}{l}\text { Adj. } \\
\text { comentário }\end{array}$ & Complemento \\
\hline Ator Social & & & & $\begin{array}{l}\text { Inclusão - passivação - } \\
\text { beneficiação -Assimilação }\end{array}$ \\
\hline
\end{tabular}

É evidente que a população que foi às ruas ontem, Presidente Biffi, especialmente os mais jovens, que foram maioria nas manifestações, querem uma saúde pública cada vez melhor, querem uma educação cada vez mais qualificada, querem transporte público mais barato e em condições cada vez mais qualificadas.

\begin{tabular}{|l|l|l|l|l|}
\hline & É evidente & $\begin{array}{l}\text { que a população } \\
\text { que foi às ruas } \\
\text { ontem, }\end{array}$ & Presidente Biffi, & $\begin{array}{l}\text { especialmente os } \\
\text { mais jovens, que } \\
\text { foram maioria nas } \\
\text { manifestações, }\end{array}$ \\
\hline
\end{tabular}




\begin{tabular}{|l|l|l|l|l|} 
Transitividade & & Experienciador & & \\
\hline Sistema de Modo & $\begin{array}{l}\text { Metáfora } \\
\text { interpessoal }\end{array}$ & Sujeito & Vocativo & Adj. Comentário \\
\hline Ator Social & & $\begin{array}{l}\text { Impessoalização - } \\
\text { Assimilação - } \\
\text { Coletivização }\end{array}$ & $\begin{array}{l}\text { Inclusão - } \\
\text { Pessoalização - } \\
\text { Nomeação - } \\
\text { Formalização }\end{array}$ & $\begin{array}{l}\text { Pessoalização - } \\
\text { categorização }\end{array}$ \\
\hline
\end{tabular}

\begin{tabular}{|l|l|l|}
\hline & querem & uma saúde pública cada vez melhor, \\
\hline Transitividade & $\begin{array}{l}\text { Proc. Mental } \\
\text { Desiderativo }\end{array}$ & Fenômeno \\
\hline Sistema de Modo & Finito + Predicador & Complemento \\
\hline Ator Social & & \\
\hline
\end{tabular}

Sr. Presidente, Sras. e Srs. Deputados, a pauta que está posta para este Parlamento é ouvir sim aquilo que a sociedade está colocando.

\begin{tabular}{|l|l|l|l|l|}
\hline & $\begin{array}{l}\text { Sr. Presidente, Sras. e Srs. } \\
\text { Deputados, }\end{array}$ & $\begin{array}{l}\text { a pauta que } \\
\text { está posta } \\
\text { para este } \\
\text { Parlamento }\end{array}$ & é & $\begin{array}{l}\text { ouvir sim aquilo que } \\
\text { a sociedade está } \\
\text { colocando. }\end{array}$ \\
\hline Transitividade & & Identificado & $\begin{array}{l}\text { Proc. } \\
\text { Relacional }\end{array}$ & Identificador \\
\hline $\begin{array}{l}\text { Sistema de } \\
\text { Modo }\end{array}$ & Vocativo & Sujeito & $\begin{array}{l}\text { Finito + } \\
\text { Predicador }\end{array}$ & Complemento \\
\hline Ator Social & $\begin{array}{l}\text { Inclusão - } \\
\text { PessoalizaçãoFuncionalização }\end{array}$ & & & $\begin{array}{l}\text { Inclusão - Ativação - } \\
\text { Impessoalização - } \\
\text { Assimilação - } \\
\text { Coletivização }\end{array}$ \\
\hline
\end{tabular}


Nosso Governo entende os movimentos que ocorreram ontem como um alerta para que nós continuemos aprofundando mudanças, reconhecendo erros, ampliando conquistas e, acima de tudo, sabendo que nunca um país está pronto e que nunca alguém pode se sentir o dono da verdade.

\begin{tabular}{|l|l|l|l|}
\hline & Nosso Governo & entende & $\begin{array}{l}\text { os movimentos que ocorreram } \\
\text { ontem... }\end{array}$ \\
\hline Transitividade & Experienciador & Proc. Mental & Fenômeno \\
\hline Sistema de Modo & Sujeito & $\begin{array}{l}\text { Finito + } \\
\text { Predicador }\end{array}$ & Complemento \\
\hline Ator Social & $\begin{array}{l}\text { Inclusão - } \\
\text { Ativação - } \\
\text { Pessoalização - } \\
\text { Determinação - } \\
\text { Diferenciação }\end{array}$ & $\begin{array}{l}\text { Implusão - Passivação - } \\
\text { - Coletivizaçãão } ~\end{array}$ \\
\hline
\end{tabular}

\section{O SR. JOSÉ GUIMARÃES (PT-CE. Como Líder)}

A bancada do PT na Câmara saúda as manifestações populares que têm ocorrido nas ruas de diferentes cidades brasileiras.

\begin{tabular}{|l|l|l|l|}
\hline & $\begin{array}{l}\text { A bancada do PT na } \\
\text { Câmara }\end{array}$ & saúda & $\begin{array}{l}\text { as manifestações populares que } \\
\text { têm ocorrido nas ruas de diferentes } \\
\text { cidades brasileiras. }\end{array}$ \\
\hline Transitividade & Dizente & Proc. Verbal & Alvo \\
\hline Sistema de Modo & Sujeito & $\begin{array}{l}\text { Finito + } \\
\text { Predicador }\end{array}$ & Complemento \\
\hline Ator Social & $\begin{array}{l}\text { Inclusão-Ativação- } \\
\text { Pessoalização - } \\
\text { categorização }\end{array}$ & $\begin{array}{l}\text { Inclusão - Ativação - } \\
\text { Impessoalização - Assimilação - } \\
\text { Coletivização }\end{array}$ \\
\hline
\end{tabular}


"O Brasil acordou nesta terça-feira mais forte com as manifestações realizadas em todo o País, comprovando a energia da nossa democracia, a força das vozes da rua e o civismo de nossa população".

\begin{tabular}{|l|l|l|l|}
\hline & "O Brasil & acordou & nesta terça-feira \\
\hline Transitividade & Comportante & Proc. Comportamental & Circunstância \\
\hline Sistema de Modo & Sujeito & Finito + Predicador & Adj. Modo \\
\hline Ator Social & $\begin{array}{l}\text { Inclusão- Ativação - } \\
\text { objetivação - } \\
\text { espacialização }\end{array}$ & & \\
\hline
\end{tabular}

\begin{tabular}{|l|l|l|l|}
\hline & $\begin{array}{l}\text { mais forte com as manifestações } \\
\text { realizadas em todo o País, }\end{array}$ & comprovando & $\begin{array}{l}\text { a energia da nossa } \\
\text { democracia, a força das } \\
\text { vozes da rua e o civismo } \\
\text { de nossa população". }\end{array}$ \\
\hline Transitividade & Circunstância & Proc. Material & Meta \\
\hline Sistema de & $\begin{array}{l}\text { Adj. Modo } \\
\text { Ator Social }\end{array}$ & $\begin{array}{l}\text { Passivação - Sujeição } \\
\text { circunstacializaçãoImpessoalização- } \\
\text { Assimilação- Coletivização. }\end{array}$ & Predicador \\
\hline
\end{tabular}

As manifestações são legítimas e as reivindicações e os métodos para expressá-las fazem parte do sistema democrático brasileiro.

\begin{tabular}{|l|l|l|l|}
\hline & As manifestações & são & legítimas \\
\hline Transitividade & Portador & Proc. Relacional & Atributo \\
\hline
\end{tabular}




\begin{tabular}{|l|l|l|l|} 
Sistema de Modo & Sujeito & Finito + Predicador & Complemento \\
\hline Ator Social & $\begin{array}{l}\text { Passivação - } \\
\text { Sujeição } \\
\text { Impessoalização- } \\
\text { Assimilação- } \\
\text { Coletivização }\end{array}$ & & \\
& & & \\
\hline
\end{tabular}

\begin{tabular}{|l|l|l|l|}
\hline & $\begin{array}{l}\text { e as reivindicações e } \\
\text { os métodos para } \\
\text { expressá-las }\end{array}$ & fazem & $\begin{array}{l}\text { parte do sistema democrático } \\
\text { brasileiro. }\end{array}$ \\
\hline Transitividade & Portador & $\begin{array}{l}\text { Proc. } \\
\text { Relacional }\end{array}$ & Atributo \\
\hline Sistema de Modo & Sujeito & $\begin{array}{l}\text { Finito + } \\
\text { Predicador }\end{array}$ & \\
\hline Ator Social & & & $\begin{array}{l}\text { Inclusão - Impessoalização - } \\
\text { abstração }\end{array}$ \\
\hline
\end{tabular}

Os milhares de manifestantes deram um duro recado aos governantes de todas as instâncias e aos três Poderes da República;

\begin{tabular}{|l|l|l|l|l|}
\hline & $\begin{array}{l}\text { Os milhares de } \\
\text { manifestantes }\end{array}$ & deram & um duro recado & $\begin{array}{l}\text { aos governantes de } \\
\text { todas as instâncias e } \\
\text { aos três Poderes da } \\
\text { República; }\end{array}$ \\
\hline Transitividade & Ator & $\begin{array}{l}\text { Proc. } \\
\text { Material }\end{array}$ & Meta & Beneficiário \\
\hline Sistema de Modo & Sujeito & $\begin{array}{l}\text { Finito + } \\
\text { Predicador }\end{array}$ & Complemento & \\
\hline
\end{tabular}




\begin{tabular}{|l|l|l|} 
Ator Social $\mid \begin{array}{l}\text { Inclusão - Ativação } \\
\text { - Impessoalização- } \\
\text { Assimilação- } \\
\text { Agregação }\end{array}$ & $\begin{array}{l}\text { Passivação - } \\
\text { beneficiação - } \\
\text { pessoalização - } \\
\text { determinação - } \\
\text { associação }\end{array}$ \\
\hline
\end{tabular}

A bancada do PT e nosso Governo estão em plena sintonia com as reivindicações expressas nas ruas, pois elas são produto de uma sociedade em transformação e em busca de novas conquistas e que consolidem o Brasil como um dos países mais democráticos do nosso planeta.

\begin{tabular}{|l|l|l|l|}
\hline & $\begin{array}{l}\text { A bancada do PT e } \\
\text { nosso Governo }\end{array}$ & $\begin{array}{l}\text { estão } \\
\text { reivindicações expressas nas } \\
\text { ruas, }\end{array}$ \\
\hline Transitividade & Portador & Proc. Relacional & Atributo \\
\hline Sistema de Modo & Sujeito & $\begin{array}{l}\text { Finito + } \\
\text { Predicador }\end{array}$ & Complemento \\
\hline Ator Social & $\begin{array}{l}\text { Inclusão-Ativação- } \\
\text { Pessoalização - } \\
\text { categorização } \\
\text { Diferenciação }\end{array}$ & Impessoalização - abstração \\
\hline
\end{tabular}

\begin{tabular}{|l|l|l|l|}
\hline & , pois elas & São & $\begin{array}{l}\text { produto de uma sociedade em } \\
\text { transformação e em busca de } \\
\text { novas conquistas e que } \\
\text { consolidem o Brasil como um } \\
\text { dos países mais democráticos } \\
\text { do nosso planeta. }\end{array}$ \\
\hline Transitividade & Portador & Proc. Relacional & Atributo \\
\hline
\end{tabular}




\begin{tabular}{|l|l|l|l|} 
Sistema de Modo & Sujeito & $\begin{array}{l}\text { Finito }+ \\
\text { Predicador }\end{array}$ & Complemento \\
\hline Ator Social & & & \\
\hline
\end{tabular}

A democracia representativa torna-se mais forte com a incorporação da mobilização popular, das vozes do povo e das manifestações expressadas por pessoas de diferentes orientações políticas e ideológicas.

\begin{tabular}{|l|l|l|l|}
\hline & $\begin{array}{l}\text { A democracia } \\
\text { representativa }\end{array}$ & torna-se & $\begin{array}{l}\text { mais forte com a incorporação da } \\
\text { mobilização popular, das vozes } \\
\text { do povo e das manifestaçães } \\
\text { expressadas por pessoas de } \\
\text { diferentes orientações políticas e } \\
\text { ideológicas. }\end{array}$ \\
\hline Transitividade & Portador & $\begin{array}{l}\text { Proc. } \\
\text { Relacional }\end{array}$ & Atributo \\
\hline Sistema de Modo & Sujeito & $\begin{array}{l}\text { Finito + } \\
\text { Predicador }\end{array}$ & Complemento \\
\hline Ator Social & $\begin{array}{l}\text { Inclusão - } \\
\text { Impessoalização por } \\
\text { abstração }\end{array}$ & $\begin{array}{l}\text { Inclusão - Passivação } \\
\text { Impessoalização- Assimilação- } \\
\text { Coletivização. }\end{array}$ \\
\hline
\end{tabular}

O povo na rua é nossa história.

\begin{tabular}{|l|l|l|l|}
\hline & O povo na rua & É & nossa história. \\
\hline Transitividade & Identificado & $\begin{array}{l}\text { Proc. } \\
\text { Relacional }\end{array}$ & Identificador \\
\hline Sistema de Modo & Sujeito & Finito + & Complemento \\
\hline
\end{tabular}




\begin{tabular}{|l|l|l|l|} 
& & Predicador & \\
\hline Ator Social & $\begin{array}{l}\text { Inclusão - } \\
\text { Ativação } \\
\text { assimilação - } \\
\text { coletivização, }\end{array}$ & & \\
& & \\
\hline
\end{tabular}

Ouvir as vozes das ruas é dever de todos os poderes.

\begin{tabular}{|l|l|l|l|}
\hline & $\begin{array}{l}\text { Ouvir as vozes das } \\
\text { ruas }\end{array}$ & é & dever de todos os poderes. \\
\hline Transitividade & Identificado & $\begin{array}{l}\text { Proc. } \\
\text { Relacional }\end{array}$ & Identificador \\
\hline Sistema de Modo & Sujeito & $\begin{array}{l}\text { Finito + } \\
\text { Predicador }\end{array}$ & Complemento \\
\hline Ator Social & $\begin{array}{l}\text { Inclusão - Passivação } \\
\text { - Beneficiação - } \\
\text { impessoalização - } \\
\text { objetivação - } \\
\text { espacialização }\end{array}$ & $\begin{array}{l}\text { Inclusão - Impessoalização- } \\
\text { Abstração }\end{array}$ \\
\hline
\end{tabular}

A manifestação aqui foi pacífica e democrática.

\begin{tabular}{|l|l|l|l|}
\hline & $\begin{array}{l}\text { A manifestação } \\
\text { aqui }\end{array}$ & Foi & pacífica e democrática. \\
\hline Transitividade & Portador & Proc. Relacional & Atributo \\
\hline Sistema de Modo & Sujeito & $\begin{array}{l}\text { Finito + } \\
\text { Predicador }\end{array}$ & Complemento \\
\hline Ator Social & $\begin{array}{l}\text { Inclusão - } \\
\text { ativação- } \\
\text { Impessoalização- }\end{array}$ & & \\
\hline
\end{tabular}




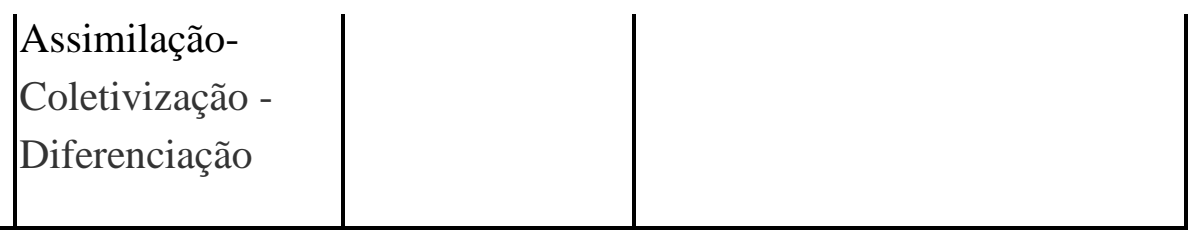

Não é um movimento contra a Presidenta Dilma.

\begin{tabular}{|l|l|l|l|l|}
\hline & (Este) & Não & é & $\begin{array}{l}\text { um movimento contra a } \\
\text { Presidenta Dilma. }\end{array}$ \\
\hline Transitividade & Portador & & Proc. Relacional & Atributo \\
\hline $\begin{array}{l}\text { Sistema de } \\
\text { Modo }\end{array}$ & Sujeito & Polaridade & $\begin{array}{l}\text { Finito + } \\
\text { Predicador }\end{array}$ & Complemento \\
\hline Ator Social & & & & $\begin{array}{l}\text { Ativação - Sujeição - } \\
\text { Impessoalização - Assimilação } \\
\text { Pessoalização- Determinação- } \\
\text { Nomeação }\end{array}$ \\
\hline
\end{tabular}

Nós do PT não nos sentimos intimidados com nenhuma manifestação.

\begin{tabular}{|l|l|l|l|l|}
\hline & Nós do PT & Não & nos sentimos & $\begin{array}{l}\text { intimidados com nenhuma } \\
\text { manifestação }\end{array}$ \\
\hline Transitividade & Experienciador & & $\begin{array}{l}\text { Proc. Mental } \\
\text { emotivo }\end{array}$ & Fenômeno \\
\hline Sistema de Modo & Sujeito & Polaridade & $\begin{array}{l}\text { Finito + } \\
\text { Predicador }\end{array}$ & complemento \\
\hline Ator Social & $\begin{array}{l}\text { Pessoalização - } \\
\text { Determinação - } \\
\text { Diferenciação }\end{array}$ & & $\begin{array}{l}\text { Inclusão - ativação - } \\
\text { Impessoalização- Assimilação- } \\
\text { Coletivização. }\end{array}$ \\
\hline
\end{tabular}

E o movimento precisa dialogar com o Congresso Nacional 


\begin{tabular}{|l|l|l|l|}
\hline & E o movimento & precisa dialogar & com o Congresso Nacional \\
\hline Transitividade & Dizente & Proc. Verbal & Alvo \\
\hline Sistema de & Sujeito & $\begin{array}{l}\text { Modulação obrigação } \\
\text { + Finito + Predicador }\end{array}$ & Complemento \\
\hline Ator Social & $\begin{array}{l}\text { Inclusão - ativação } \\
\text { - Impessoalização } \\
\text { - Assimilação - } \\
\text { Coletivização }\end{array}$ & $\begin{array}{l}\text { Inclusão - Impessoalização - } \\
\text { objetivação - espacialização }\end{array}$ \\
\hline
\end{tabular}

É a juventude do Brasil, que agora quer construir uma outra agenda.

\begin{tabular}{|l|l|l|l|l|}
\hline & $\begin{array}{l}\text { É a juventude do } \\
\text { Brasil, que }\end{array}$ & Agora & quer & construir uma outra agenda. \\
\hline Transitividade & Experienciador & Pesiderativo & Fenômeno \\
\hline Sistema de Modo & $\begin{array}{l}\text { Expletivos + } \\
\text { Sujeito }\end{array}$ & Adj. Modo & $\begin{array}{l}\text { Finito + } \\
\text { Predicador }\end{array}$ & Complemento \\
\hline Ator Social & $\begin{array}{l}\text { Inclusão - } \\
\text { Pessoalização - } \\
\text { categorização }\end{array}$ & & & \\
\hline
\end{tabular}

E esta Casa tem que construir uma outra agenda, para podermos dar vazão a essas manifestações ocorridas no Brasil afora.

\begin{tabular}{|l|l|l|l|l|}
\hline & E esta Casa & tem que & construir & $\begin{array}{l}\text { uma outra agenda, para podermos } \\
\text { dar vazão a essas manifestações } \\
\text { ocorridas no Brasil afora. }\end{array}$ \\
\hline Transitividade & Ator & & Proc. & Meta \\
\hline
\end{tabular}




\begin{tabular}{|l|l|l|l|l|} 
& & & $\begin{array}{l}\text { Material } \\
\text { Criativo }\end{array}$ & \\
\hline $\begin{array}{l}\text { Sistema de } \\
\text { Modo }\end{array}$ & Sujeito & $\begin{array}{l}\text { Modulação } \\
\text { obrigação }\end{array}$ & $\begin{array}{l}\text { Finito + } \\
\text { Predicador }\end{array}$ & Complemento \\
\hline Ator Social & $\begin{array}{l}\text { Inclusão - } \\
\text { Ativação - } \\
\text { Impessoalização - } \\
\text { Objetivação - } \\
\text { Espacialização }\end{array}$ & & $\begin{array}{l}\text { Inclusão - Passivação - } \\
\text { Impessoalização- Assimilação- } \\
\text { Coletivização. }\end{array}$ \\
\hline
\end{tabular}

\section{O SR. MÁRIO HERINGER (PDT-MG. Como Líder)}

Senhoras e senhores, a sociedade está dizendo para nós que está cansada do jeito que a gente faz política, que está cansada de ser levada e empurrada com a barriga.

\begin{tabular}{|l|l|l|l|l|}
\hline & $\begin{array}{l}\text { Senhoras e } \\
\text { senhores, }\end{array}$ & a sociedade & está & dizendo \\
\hline Transitividade & & Dizente & \multicolumn{2}{|l|}{ Processo Verbal } \\
\hline Sistema de Modo & Vocativo & Sujeito & Finito & Predicador \\
\hline Ator Social & & $\begin{array}{l}\text { Ativação - } \\
\text { Inclusão } \\
\text { Impessoalização } \\
\text { - Assimilação - } \\
\text { Coletivização }\end{array}$ & & \\
\hline
\end{tabular}

\begin{tabular}{|l|l|l|}
\hline & para nós & $\begin{array}{l}\text { que está cansada do jeito que a gente faz política, que está } \\
\text { cansada de ser levada e empurrada com a barriga. }\end{array}$ \\
\hline Transitividade & Receptor & Verbiagem \\
\hline $\begin{array}{l}\text { Sistema de } \\
\text { Modo }\end{array}$ & \multicolumn{2}{|c|}{ Complemento } \\
\hline
\end{tabular}


\begin{tabular}{|l|l|l|} 
Ator Social & $\begin{array}{l}\text { Inclusão- } \\
\text { passivação - } \\
\text { Personalização - } \\
\text { indeterminação }\end{array}$ & \\
\hline
\end{tabular}

Infelizmente, o que nós fazemos e o que temos feito não mais atende ao que essa sociedade quer.

\begin{tabular}{|c|c|c|c|c|c|}
\hline & Infelizmente, & $\begin{array}{l}\text { o que nós } \\
\text { fazemos e o que } \\
\text { temos feito }\end{array}$ & não mais & atende & $\begin{array}{l}\text { ao que essa } \\
\text { sociedade quer. }\end{array}$ \\
\hline Transitividade & & Ator & & $\begin{array}{l}\text { Proc. } \\
\text { Material }\end{array}$ & Meta \\
\hline Sistema de Modo & $\begin{array}{l}\text { Adj. } \\
\text { comentário }\end{array}$ & Sujeito & $\begin{array}{l}\text { Polaridade } \\
+ \text { adj. Modo }\end{array}$ & $\begin{array}{l}\text { Finito }+ \\
\text { Predicador }\end{array}$ & Complemento \\
\hline Ator Social & & $\begin{array}{l}\text { Inclusão- } \\
\text { passivação - } \\
\text { Pessoalização - } \\
\text { Determinação - } \\
\text { Diferenciação }\end{array}$ & & & \begin{tabular}{|l|} 
Ativação - Inclusão \\
Impessoalização - \\
Assimilação - \\
Coletivização
\end{tabular} \\
\hline
\end{tabular}

O momento, Sr. Presidente, Srs. Deputados, é de ouvir essa sociedade, e uma maneira de ouvir essa sociedade é uma maneira constitucional.

\begin{tabular}{|l|l|l|l|l|}
\hline & O momento, & $\begin{array}{l}\text { Sr. Presidente, Srs. } \\
\text { Deputados, }\end{array}$ & de ouvir essa sociedade, e \\
\hline Transitividade & Portador & Relacional & Atributo \\
\hline Sistema de Modo & Sujeito & Vocativo & $\begin{array}{l}\text { Finito + } \\
\text { Predicador }\end{array}$ & Complemento \\
\hline Ator Social & & $\begin{array}{l}\text { Inclusão - } \\
\text { Pessoalização - } \\
\text { Determinação - }\end{array}$ & $\begin{array}{l}\text { Inclusão - Passivação - } \\
\text { Impessoalização - }\end{array}$ \\
\hline
\end{tabular}


Categorização -

|Assimilação -Coletivização

Funcionalização

\begin{tabular}{|l|l|l|l|}
\hline & $\begin{array}{l}\text { uma maneira de } \\
\text { ouvir essa } \\
\text { sociedade }\end{array}$ & É & uma maneira constitucional. \\
\hline Transitividade & Portador & Proc. Relacional & Atributo \\
\hline Sistema de Modo & Sujeito & $\begin{array}{l}\text { Finito + } \\
\text { Predicador }\end{array}$ & Complemento \\
\hline Ator Social & $\begin{array}{l}\text { Inclusão - } \\
\text { Passivação - } \\
\text { Impessoalização - } \\
\text { Assimilação - } \\
\text { Coletivização }\end{array}$ & & \\
\hline
\end{tabular}

Nós temos que perguntar a essa sociedade, através do plebiscito, o que ela quer fazer, dentro dos temas que nós temos que discutir.

\begin{tabular}{|l|l|l|l|l|}
\hline & Nós & temos que & perguntar & a essa sociedade \\
\hline Transitividade & Dizente & Proc. Verbal & Receptor \\
\hline Sistema de Modo & Sujeito & $\begin{array}{l}\text { Modulação } \\
\text { obrigação }\end{array}$ & $\begin{array}{l}\text { Finito+ } \\
\text { Predicador }\end{array}$ & Complemento \\
\hline Ator Social & $\begin{array}{l}\text { Inclusão- } \\
\text { Ativação - } \\
\text { Pessoalização - } \\
\text { Determinação } \\
\text { Diferenciação }\end{array}$ & & $\begin{array}{l}\text { Inclusão - Passivação - } \\
\text { Impessoalização - }\end{array}$ \\
\hline
\end{tabular}




\begin{tabular}{|l|l|l|l|}
\hline & $\begin{array}{l}\text { através do } \\
\text { plebiscito, }\end{array}$ & $\begin{array}{l}\text { o que ela quer } \\
\text { fazer, }\end{array}$ & $\begin{array}{l}\text { dentro dos temas que nós temos que } \\
\text { discutir. }\end{array}$ \\
\hline Transitividade & Circunstância & Verbiagem & Circunstância \\
\hline Sistema de Modo & Adj. Modo & Complemento & Adj. Modo \\
\hline Ator Social & & $\begin{array}{l}\text { Inclusão- } \\
\text { Ativação - } \\
\text { Pessoalização- } \\
\text { Determinação } \\
\text { Diferenciação }\end{array}$ & \\
\hline
\end{tabular}

Está na hora de ouvir essa sociedade e de dizer para essa sociedade que é ela que nos comanda.

\begin{tabular}{|l|l|l|l|l|}
\hline & \multicolumn{2}{|l|}{ Está na hora } & de ouvir & essa sociedade \\
\hline Transitividade & \multicolumn{2}{|l|}{ Circunstância de tempo } & $\begin{array}{l}\text { Proc. Mental } \\
\text { Perceptivo }\end{array}$ & Fenômeno \\
\hline Sistema de Modo & Metáfora interpessoal & $\begin{array}{l}\text { Finito + } \\
\text { Predicador }\end{array}$ & Complemento \\
\hline Ator Social & & & & $\begin{array}{l}\text { Inclusão - Passivação - } \\
\text { Impessoalização - } \\
\text { Assimilação -Coletivização }\end{array}$ \\
\hline
\end{tabular}

\begin{tabular}{|c|c|c|c|}
\hline & e de dizer & para essa sociedade & que é ela que nos comanda. \\
\hline Transitividade & Proc. Verbal & Receptor & Verbiagem \\
\hline Sistema de & Finito + & Complemento & Complemento \\
\hline
\end{tabular}




\begin{tabular}{|l|l|l|l|l|l|} 
Modo & Predicador & & Predicador & & \\
\hline Ator Social & & $\begin{array}{l}\text { Inclusão - } \\
\text { Passivação - } \\
\text { Impessoalização - } \\
\text { Assimilação - } \\
\text { Coletivização }\end{array}$ & & & \\
& & & & \\
\hline
\end{tabular}

Infelizmente, senhoras e senhores, esse movimento chegou tarde.

\begin{tabular}{|l|l|l|l|l|l|}
\hline & Infelizmente, & $\begin{array}{l}\text { senhoras e } \\
\text { senhores, }\end{array}$ & esse movimento & chegou & tarde. \\
\hline Transitividade & & & Ator & $\begin{array}{l}\text { Proc. } \\
\text { Material }\end{array}$ & Circunstância \\
\hline Sistema de Modo & $\begin{array}{l}\text { Adj. } \\
\text { Comentário }\end{array}$ & Vocativo & Sujeito & $\begin{array}{l}\text { Finito + } \\
\text { Predicador }\end{array}$ & Complemento \\
\hline Ator Social & & & $\begin{array}{l}\text { Impessoalização - } \\
\text { Assimilação - } \\
\text { Coletivização }\end{array}$ & & \\
\hline
\end{tabular}

Mas a sociedade não esquece.

\begin{tabular}{|c|c|c|c|c|}
\hline & Mas & a sociedade & não & esquece. \\
\hline Transitividade & & Experienciador & & Proc. Mental Cognitivo \\
\hline Sistema de Modo & Conjunção & Sujeito & Polaridade & Finito + Predicador \\
\hline Ator Social & & $\begin{array}{l}\text { Inclusão - Ativação } \\
\text { - Impessoalização - } \\
\text { Assimilação - } \\
\text { Coletivização }\end{array}$ & & \\
\hline
\end{tabular}


A passagem, os 20 centavos da passagem foram os 20 centavos mais benditos que aconteceram para a sociedade brasileira, porque trouxeram os brasileiros, e nós desta Casa estarrecidos e extasiados pelo sucesso de uma manifestação que já deveria ter ocorrido.

\begin{tabular}{|l|l|l|l|}
\hline & $\begin{array}{l}\text { A passagem, os } \\
20 \text { centavos da } \\
\text { passagem }\end{array}$ & Foram & $\begin{array}{l}\text { os 20 centavos mais benditos que } \\
\text { aconteceram para a sociedade brasileira, }\end{array}$ \\
\hline Transitividade & Portador & $\begin{array}{l}\text { Proc. } \\
\text { Relacional }\end{array}$ & Atributo \\
\hline Sistema de Modo & Sujeito & $\begin{array}{l}\text { Finito + } \\
\text { Predicador }\end{array}$ & Complemento \\
\hline Ator Social & & & $\begin{array}{l}\text { Inclusão - Passivação - Beneficiação - } \\
\text { Impessoalização - Assimilação - } \\
\text { Coletivização }\end{array}$ \\
\hline
\end{tabular}

\begin{tabular}{|l|l|l|l|}
\hline & porque & trouxeram & $\begin{array}{l}\text { os brasileiros , e nós desta Casa estarrecidos } \\
\text { e extasiados pelo sucesso de uma } \\
\text { manifestação que já deveria ter ocorrido. }\end{array}$ \\
\hline Transitividade & & $\begin{array}{l}\text { Processo } \\
\text { Material }\end{array}$ & Meta \\
\hline Sistema de Modo & Conjunção & $\begin{array}{l}\text { Finito + } \\
\text { Predicador }\end{array}$ & Complemento \\
\hline Ator Social & & & $\begin{array}{l}\text { Inclusão - passivação - sujeição- } \\
\text { Impessoalização- Assimilação- } \\
\text { Coletivização }\end{array}$ \\
\hline
\end{tabular}


Nós estamos aqui é para bater palmas para um Brasil que participa, para bater palma para um Brasil que reivindica.

\begin{tabular}{|l|l|l|l|l|l|}
\hline & Nós & estamos & aqui & é & para bater palmas \\
\hline Transitividade & Portador & $\begin{array}{l}\text { Proc. } \\
\text { Relacional }\end{array}$ & Atributo & $\begin{array}{l}\text { Circunstância de } \\
\text { finalidade }\end{array}$ \\
\hline Sistema de Modo & Sujeito & $\begin{array}{l}\text { Finito + } \\
\text { Predicador }\end{array}$ & Complemento & Expletivo & Adj. Modo \\
\hline Ator Social & $\begin{array}{l}\text { Inclusão- ativação } \\
- \text { Personalização - } \\
\text { indeterminação }\end{array}$ & & & & \\
\hline
\end{tabular}

\begin{tabular}{|l|l|l|l|}
\hline & $\begin{array}{l}\text { para um Brasil que } \\
\text { participa }\end{array}$ & $\begin{array}{l}\text { para bater } \\
\text { palma }\end{array}$ & para um Brasil que reivindica. \\
\hline Transitividade & \multicolumn{2}{|c|}{ Circunstância de finalidade } \\
\hline $\begin{array}{l}\text { Sistema de } \\
\text { Modo }\end{array}$ & $\begin{array}{l}\text { Adjunto de Modo } \\
\text { Passivação - } \\
\text { Beneficiação - } \\
\text { impessoalização - } \\
\text { objetivação - } \\
\text { espacialização - } \\
\text { Diferenciação }\end{array}$ & $\begin{array}{l}\text { Inclusão - Passivação - } \\
\text { Beneficiação - impessoalização - } \\
\text { objetivação - espacialização - } \\
\text { Diferenciação }\end{array}$ \\
\hline
\end{tabular}

o PDT quer colocar a sua posição de parar. Não vamos tomar decisões açodadas e correndo. É parar e conversar com a sociedade, é ouvir a sociedade. 
o PDT quer colocar a sua posição [de parar e conversar com a sociedade], o PDT quer colocar a sua posição [de ouvir a sociedade].

\begin{tabular}{|c|c|c|c|}
\hline & o PDT & Quer & $\begin{array}{l}\text { colocar a sua posição de parar e } \\
\text { conversar com a sociedade, }\end{array}$ \\
\hline Transitividade & Experienciador & $\begin{array}{l}\text { Proc. Mental } \\
\text { desiderativo }\end{array}$ & Fenômeno \\
\hline Sistema de Modo & Sujeito & $\begin{array}{l}\text { Finito }+ \\
\text { Predicador }\end{array}$ & Complemento \\
\hline Ator Social & $\begin{array}{l}\text { Inclusão- } \\
\text { Ativação - } \\
\text { Pessoalização - } \\
\text { Determinação - } \\
\text { Diferenciação }\end{array}$ & & $\begin{array}{l}\text { Inclusão - Passivação - } \\
\text { Impessoalização - Assimilação - } \\
\text { Coletivização }\end{array}$ \\
\hline
\end{tabular}

\begin{tabular}{|l|l|l|l|}
\hline & o PDT & Quer & $\begin{array}{l}\text { colocar a sua posição de ouvir a } \\
\text { sociedade, }\end{array}$ \\
\hline Transitividade & Experienciador & $\begin{array}{l}\text { Proc. Mental } \\
\text { desiderativo }\end{array}$ & Fenômeno \\
\hline Sistema de Modo & $\begin{array}{l}\text { Sujeito } \\
\text { Ator Social }\end{array}$ & $\begin{array}{l}\text { Finito + } \\
\text { Predicador } \\
\text { Ativação - } \\
\text { Pessoalização - } \\
\text { Determinação - } \\
\text { Diferenciação }\end{array}$ & Complemento \\
\hline
\end{tabular}

Nós não vamos ter o respeito de nós mesmos, desta Casa, não vamos ter o respeito do povo brasileiro se nós acharmos que isso é só uma lufada de liberdade. 


\begin{tabular}{|l|l|l|l|l|}
\hline & Nós & não & vamos ter & $\begin{array}{l}\text { o respeito de nós mesmos, } \\
\text { desta Casa, }\end{array}$ \\
\hline Transitividade & Possuidor & $\begin{array}{l}\text { Proc. } \\
\text { Relacional } \\
\text { Possessivo }\end{array}$ & Possuído \\
\hline Sistema de Modo & Sujeito & Polaridade & $\begin{array}{l}\text { Finito+ } \\
\text { Predicador }\end{array}$ & Complemento \\
\hline Ator Social & $\begin{array}{l}\text { Inclusão- } \\
\text { passivação - } \\
\text { Personalização - } \\
\text { indeterminação }\end{array}$ & & $\begin{array}{l}\text { Inclusão - Passivação - } \\
\text { Pessoalização - } \\
\text { Determinação - } \\
\text { Diferenciação }\end{array}$ \\
\hline
\end{tabular}

\begin{tabular}{|l|l|l|l|}
\hline & não & vamos ter & o respeito do povo brasileiro \\
\hline Transitividade & & $\begin{array}{l}\text { Proc. } \\
\text { Relacional } \\
\text { Possessivo }\end{array}$ & Possuído \\
\hline Sistema de Modo & Polaridade & $\begin{array}{l}\text { Finito+ } \\
\text { Predicador }\end{array}$ & Complemento \\
\hline Ator Social & & & $\begin{array}{l}\text { Inclusão - Passivação Impessoalização - } \\
\text { Assimilação -Coletivização }\end{array}$ \\
\hline
\end{tabular}

\begin{tabular}{|l|l|l|l|l|}
\hline & se & nós & acharmos & $\begin{array}{l}\text { que isso é só uma lufada de } \\
\text { liberdade. }\end{array}$ \\
\hline Transitividade & & Experienciador & $\begin{array}{l}\text { Proc. Mental } \\
\text { Cognitivo }\end{array}$ & Fenômeno \\
\hline
\end{tabular}




\begin{tabular}{|l|l|l|l|l|} 
Sistema de Modo & Conjunção & Sujeito & $\begin{array}{l}\text { Finito + } \\
\text { Predicador }\end{array}$ & Complemento \\
\hline Ator Social & & $\begin{array}{l}\text { Inclusão- } \\
\text { passivação - } \\
\text { Personalização - } \\
\text { indeterminação }\end{array}$ & & \\
\hline
\end{tabular}

O SR. MENDONÇA FILHO (DEM-PE. Como Líder)

Sr. Presidente, Sras. e Srs. Deputados, o Brasil ontem ouviu literalmente a chamada voz rouca das ruas.

\begin{tabular}{|c|c|c|c|c|c|c|}
\hline & $\begin{array}{l}\text { Sr. Presidente, } \\
\text { Sras. e Srs. } \\
\text { Deputados, }\end{array}$ & o Brasil & ontem & ouviu & literalmente & \begin{tabular}{|l} 
a chamada voz \\
rouca das ruas.
\end{tabular} \\
\hline Transitividade & & Experienciador & Circunstância & $\begin{array}{l}\text { Proc. } \\
\text { Mental } \\
\text { Perceptivo }\end{array}$ & & Fenômeno \\
\hline \begin{tabular}{|l} 
Sistema de \\
Modo
\end{tabular} & Vocativo & Sujeito & Adj. Modo & $\begin{array}{l}\text { Finito }+ \\
\text { Predicador }\end{array}$ & $\begin{array}{l}\text { Adj. } \\
\text { Comentário }\end{array}$ & complemento \\
\hline Ator Social & Funcionalização & $\begin{array}{l}\text { Inclusão - } \\
\text { Ativação - } \\
\text { impessoalização } \\
\text { - objetivação - } \\
\text { espacialização }\end{array}$ & & & & $\begin{array}{l}\text { Inclusão - } \\
\text { Passivação - } \\
\text { impessoalizaçãa } \\
\text { o - objetivação } \\
- \\
\text { espacialização } \\
\text { - somatização }\end{array}$ \\
\hline
\end{tabular}

o poder público anda literalmente divorciado da sociedade brasileira. 


\begin{tabular}{|l|l|l|l|l|}
\hline & o poder público & anda & literalmente & divorciado da sociedade brasileira. \\
\hline Transitividade & Portador & $\begin{array}{l}\text { Proc. } \\
\text { relacional }\end{array}$ & Atributo \\
\hline Sistema de Modo & Sujeito & $\begin{array}{l}\text { Finito + } \\
\text { Predicador }\end{array}$ & Adj. Comentário & Complemento \\
\hline Ator Social & $\begin{array}{l}\text { Inclusão - } \\
\text { Impessoalização } \\
\text { Abstração }\end{array}$ & & & $\begin{array}{l}\text { Inclusão - Passivação - } \\
\text { Coletivizaçação }\end{array}$ \\
\hline
\end{tabular}

o Sr. Presidente da Casa em exercício, o Deputado Andre Vargas, teve conduta irrepreensível, do ponto de vista do comportamento, na recepção à grande e importante manifestação de frente ao Congresso Nacional.

\begin{tabular}{|l|l|l|l|}
\hline & $\begin{array}{l}\text { o Sr. Presidente } \\
\text { da Casa em } \\
\text { exercício, o } \\
\text { Deputado Andre } \\
\text { Vargas, }\end{array}$ & teve & $\begin{array}{l}\text { conduta irrepreensível, do ponto de vista do } \\
\text { comportamento, na recepção à grande e } \\
\text { importante manifestação de frente ao } \\
\text { Congresso Nacional. }\end{array}$ \\
\hline Transitividade & Portador & $\begin{array}{l}\text { Proc. } \\
\text { Relacional }\end{array}$ & Atributo \\
\hline Sistema de Modo & $\begin{array}{l}\text { Sujeito } \\
\text { Ator Social }\end{array}$ & $\begin{array}{l}\text { Finito + } \\
\text { Predicador } \\
\text { Ativaçãa- } \\
\text { Pessoalização - } \\
\text { Determinação - } \\
\text { Nomeação - } \\
\text { Formalização }\end{array}$ & Complemento \\
\hline
\end{tabular}


Os políticos, os Governos, todos que representam o setor público precisam ouvir a sociedade.

\begin{tabular}{|l|l|l|l|}
\hline & $\begin{array}{l}\text { Os políticos, os } \\
\text { Governos, todos que } \\
\text { representam o setor } \\
\text { público }\end{array}$ & precisam & ouvir a sociedade. \\
\hline Transitividade & $\begin{array}{l}\text { Experienciador } \\
\text { Sistema de Modo }\end{array}$ & Proc. Mental & Fenômeno \\
\hline Ator Social & $\begin{array}{l}\text { Inclusão - Ativação - } \\
\text { Pessoalização - } \\
\text { Determinação - } \\
\text { Categorização - } \\
\text { Funcionalização }\end{array}$ & $\begin{array}{l}\text { Finito + } \\
\text { Predicador }\end{array}$ & Complemento \\
Associação & $\begin{array}{l}\text { Inclusão - Ativação - } \\
\text { Coletivização }\end{array}$ \\
\hline
\end{tabular}

Quem vive o dia a dia do povo percebe claramente a distância entre a realidade da propaganda, entre a realidade do discurso e a realidade do povo.

\begin{tabular}{|c|c|c|c|c|}
\hline & Quem vive o dia a dia do povo & percebe & claramente & $\begin{array}{l}\text { a distância entre a } \\
\text { realidade da } \\
\text { propaganda, entre a } \\
\text { realidade do discurso } \\
\text { e a realidade do povo }\end{array}$ \\
\hline Transitividade & Experienciador & $\begin{array}{l}\text { Proc. Mental } \\
\text { Cognitivo }\end{array}$ & & Fenômeno \\
\hline $\begin{array}{l}\text { Sistema de } \\
\text { Modo }\end{array}$ & Sujeito & $\begin{array}{l}\text { Finito }+ \\
\text { Predicador }\end{array}$ & $\begin{array}{l}\text { Adj. } \\
\text { Comentário }\end{array}$ & Complemento \\
\hline Ator Social & $\begin{array}{l}\text { Inclusão - Ativação - } \\
\text { Pessoalização-Indeterminação }\end{array}$ & & & $\begin{array}{l}\text { Inclusão - } \\
\text { Impessoalização - } \\
\text { Assimilação - }\end{array}$ \\
\hline
\end{tabular}


É evidente que o povo quer sempre mais.

\begin{tabular}{|l|l|l|l|l|}
\hline & É evidente & que o povo & quer & sempre mais. \\
\hline Transitividade & Experienciador & $\begin{array}{l}\text { Proc. Mental } \\
\text { Desiderativo }\end{array}$ & Fenômeno \\
\hline Sistema de Modo & $\begin{array}{l}\text { Metáfora } \\
\text { interpessoal }\end{array}$ & Sujeito & $\begin{array}{l}\text { Finito + } \\
\text { Predicador }\end{array}$ & Complemento \\
\hline Ator Social & & $\begin{array}{l}\text { Inclusão - } \\
\text { Ativação - } \\
\text { Impessoalização - } \\
\text { Assimilação - } \\
\text { Coletivização }\end{array}$ & & \\
\hline
\end{tabular}

É por tudo isso, minha gente, que o povo vai às ruas, por conta da PEC 37, do descaso daqueles que representam o Governo, de parcela do Congresso Nacional que há esta revolta popular.

\begin{tabular}{|c|c|c|c|c|c|}
\hline & $\begin{array}{l}\text { É por tudo } \\
\text { isso, }\end{array}$ & minha gente, & que o povo & vai & às ruas, \\
\hline Transitividade & $\begin{array}{l}\text { Circunstância } \\
\text { de finalidade }\end{array}$ & & Ator & \begin{tabular}{|l} 
Proc. \\
Material
\end{tabular} & Meta \\
\hline $\begin{array}{l}\text { Sistema de } \\
\text { Modo }\end{array}$ & Adj. Modo & Vocativo & Sujeito & $\begin{array}{l}\text { Finito + } \\
\text { Predicador }\end{array}$ & Complemento \\
\hline Ator Social & & $\begin{array}{l}\text { Impessoalização- } \\
\text { Assimilação- } \\
\text { Coletivização } \\
\text { Diferenciação }\end{array}$ & \begin{tabular}{|l} 
Inclusão - Ativação \\
-Impessoalização- \\
Assimilação- \\
Coletivização
\end{tabular} & & \\
\hline
\end{tabular}


A gente tem que ouvir a voz do povo e oferecer a resposta correta à sociedade, fazendo com que se mude a agenda.

\begin{tabular}{|l|l|l|l|l|}
\hline & A gente & tem que & ouvir a & a voz do povo \\
\hline Transitividade & Experienciador & & $\begin{array}{l}\text { Proc. Mental } \\
\text { Perceptivo }\end{array}$ & Fenômeno \\
\hline Sistema de Modo & Sujeito & $\begin{array}{l}\text { Modulação } \\
\text { obrigação }\end{array}$ & $\begin{array}{l}\text { Finito + } \\
\text { Predicador }\end{array}$ & Complemento \\
\hline Ator Social & & & $\begin{array}{l}\text { Impessoalização- } \\
\text { Assimilação- } \\
\text { Coletivização }\end{array}$ \\
\hline
\end{tabular}

\begin{tabular}{|l|l|l|l|l|l|}
\hline & e oferecer & $\begin{array}{l}\text { resposta } \\
\text { correta }\end{array}$ & à sociedade, & fazendo & $\begin{array}{l}\text { com que se mude } \\
\text { agenda. }\end{array}$ \\
\hline Transitividade & Proc. Material & Meta & Beneficiário & Proc. Material & Meta \\
\hline $\begin{array}{l}\text { Sistema de } \\
\text { Modo }\end{array}$ & $\begin{array}{l}\text { Finito + } \\
\text { Predicador }\end{array}$ & Complemento & & $\begin{array}{l}\text { Finito + } \\
\text { Predicador }\end{array}$ & Complemento \\
\hline Ator Social & & $\begin{array}{l}\text { Passivação- } \\
\text { beneficiação - } \\
\text { Impessoalização - } \\
\text { Assimilação - } \\
\text { Coletivização }\end{array}$ & & \\
\hline
\end{tabular}

\section{O SR. MARCELO CASTRO (PMDB-PI. Como Líder)}

Primeiro, isso é um movimento nitidamente da classe média brasileira.

\begin{tabular}{|l|l|l|l|l|l|}
\hline & Primeiro, & isso & $\begin{array}{l}\text { um movimento da } \\
\text { classe média }\end{array}$ & nitidamente \\
\hline
\end{tabular}




\begin{tabular}{|l|l|l|l|l|l|}
\hline & & & & brasileira. & \\
\hline Transitividade & & Portador & $\begin{array}{l}\text { Proc. } \\
\text { Relacional }\end{array}$ & Atributo & \\
\hline Sistema de Modo & $\begin{array}{l}\text { Adj. } \\
\text { Comentário }\end{array}$ & Sujeito & $\begin{array}{l}\text { Finito + } \\
\text { Predicador }\end{array}$ & Complemento & Adj. Comentário \\
\hline Ator Social & & & & $\begin{array}{l}\text { Inclusão - } \\
\text { Pessoalização - } \\
\text { Determinação - } \\
\text { categorização- } \\
\text { Avaliação }\end{array}$ & \\
\hline
\end{tabular}

Agora, Sr. Presidente, o que é esse movimento de classe média?

\begin{tabular}{|c|c|c|c|c|c|}
\hline & Agora, & Sr. Presidente, & o que & é & $\begin{array}{l}\text { esse movimento de } \\
\text { classe média? }\end{array}$ \\
\hline Transitividade & & & Identificador & $\begin{array}{l}\text { Proc. } \\
\text { Relacional }\end{array}$ & Identificado \\
\hline Sistema de Modo & & Vocativo & Sujeito & $\begin{array}{l}\text { Finito + } \\
\text { Predicador }\end{array}$ & Complemento \\
\hline Ator Social & & $\begin{array}{l}\text { Inclusão - } \\
\text { Pessoalização - } \\
\text { Determinação - } \\
\text { Categorização - } \\
\text { Funcionalizacão }\end{array}$ & & & $\begin{array}{l}\text { Inclusão - } \\
\text { Pessoalização - } \\
\text { Determinação - } \\
\text { categorização- A } \\
\text { valiacão }\end{array}$ \\
\hline
\end{tabular}

Quem de nós, verdadeiramente, supunha, pensava, acreditava que pudesse haver no Brasil tamanha insatisfação?

\begin{tabular}{|l|l|l|l|l|}
\hline & Quem de nós, & verdadeiramente, & supunha, & que pudesse haver no \\
\hline
\end{tabular}




\begin{tabular}{|c|c|c|c|c|}
\hline & & & $\begin{array}{l}\text { pensava, } \\
\text { acreditava }\end{array}$ & $\begin{array}{l}\text { Brasil tamanha } \\
\text { insatisfação? }\end{array}$ \\
\hline Transitividade & Experienciador & & $\begin{array}{l}\text { Proc. Mental } \\
\text { Cognitivo }\end{array}$ & Fenômeno \\
\hline $\begin{array}{l}\text { Sistema de } \\
\text { Modo }\end{array}$ & Sujeito & Adj. de comentário & $\begin{array}{l}\text { Finito }+ \\
\text { Predicador }\end{array}$ & Complemento \\
\hline Ator Social & $\begin{array}{l}\text { Pessoalização - } \\
\text { Determinação- } \\
\text { Diferenciação }\end{array}$ & & & $\begin{array}{l}\text { Inclusão- Impessoalização- } \\
\text { Abstração }\end{array}$ \\
\hline
\end{tabular}

Foi preciso haver esses movimentos populares para que nós caíssemos na real e víssemos o quanto a sociedade brasileira, especialmente a classe média brasileira, está insatisfeita.

\begin{tabular}{|c|c|c|c|c|}
\hline & Foi preciso & haver & $\begin{array}{l}\text { esses movimentos } \\
\text { populares }\end{array}$ & $\begin{array}{l}\text { para que nós caíssemos na } \\
\text { real e víssemos o quanto a } \\
\text { sociedade brasileira, } \\
\text { especialmente a classe média } \\
\text { brasileira, está insatisfeita. }\end{array}$ \\
\hline Transitividade & & \begin{tabular}{|l} 
Proc. \\
Existencial
\end{tabular} & Existente & Circunstância de finalidade \\
\hline Sistema de Modo & \begin{tabular}{|l} 
Adj. \\
Comentário
\end{tabular} & $\begin{array}{l}\text { Finito + } \\
\text { Predicador }\end{array}$ & Complemento & Adj. Modo \\
\hline Ator Social & & & $\begin{array}{l}\text { Inclusão - } \\
\text { Impessoalização - } \\
\text { Assimilação - } \\
\text { Coletivização }\end{array}$ & $\begin{array}{l}\text { Pessoalização - } \\
\text { Determinação- } \\
\text { Diferenciação/ } \\
\text { Impessoalização - } \\
\text { Assimilação -Coletivização/ } \\
\text { Pessoalização - } \\
\text { Determinação - }\end{array}$ \\
\hline
\end{tabular}


Tivemos a oportunidade de avançar, de aproximar o Parlamento do povo brasileiro, de fazer partidos programáticos que pudessem representar correntes de pensamento nacional, e não o fizemos.

\begin{tabular}{|c|c|c|c|c|c|}
\hline & Tivemos & $\begin{array}{l}\text { a oportunidade de } \\
\text { avançar, de aproximar o } \\
\text { Parlamento do povo } \\
\text { brasileiro, de fazer } \\
\text { partidos programáticos } \\
\text { que pudessem } \\
\text { representar correntes de } \\
\text { pensamento nacional, }\end{array}$ & e & não o & fizemos. \\
\hline Transitividade & $\begin{array}{l}\text { Proc. } \\
\text { Relacional }\end{array}$ & Possuído & & & Proc. Material \\
\hline Sistema de Modo & $\begin{array}{l}\text { Finito + } \\
\text { Predicador }\end{array}$ & & Conjunção & Polaridade & \\
\hline Ator Social & & $\begin{array}{l}\text { Impessoalização por } \\
\text { abstração/ } \\
\text { Impessoalização - } \\
\text { Assimilação - } \\
\text { Coletivização }\end{array}$ & & & \\
\hline
\end{tabular}

\section{O SR. ARNALDO JORDY (PPS-PA. Como Líder)}

Em segundo, eu queria festejar essa onda democrática, essa manifestação cívica da sociedade brasileira, da juventude brasileira, associando-me, na análise daqueles que fazem o diagnóstico de que não houve um comando único. 


\begin{tabular}{|l|l|l|l|l|}
\hline & Em segundo, & eu & queria & festejar \\
\hline Transitividade & & Ator & $\begin{array}{l}\text { Processo } \\
\text { mental } \\
\text { desiderativo }\end{array}$ & Processo material \\
\hline Sistema de Modo & $\begin{array}{l}\text { Adjunto de } \\
\text { comentário }\end{array}$ & Sujeito & $\begin{array}{l}\text { Finito + } \\
\text { Predicador }\end{array}$ & Finito + Predicador \\
\hline Ator Social & & $\begin{array}{l}\text { Inclusão - } \\
\text { ativação }\end{array}$ & & \\
\hline
\end{tabular}

\begin{tabular}{|l|l|l|l|}
\hline & $\begin{array}{l}\text { essa onda } \\
\text { democrática, essa } \\
\text { manifestação cívica } \\
\text { da sociedade } \\
\text { brasileira, da } \\
\text { juventude brasileira, }\end{array}$ & associando-me, & $\begin{array}{l}\text { na análise daqueles que fazem } \\
\text { o diagnóstico de que não } \\
\text { houve um comando único. }\end{array}$ \\
\hline Transitividade & Meta & Processo Material & escopo \\
\hline Sistema de Modo & Complemento & Finito + Predicador & Complemento \\
\hline Ator Social & $\begin{array}{l}\text { Impessoalização - } \\
\text { Abstração } \\
\text { Impessoalização - } \\
\text { Assimilação - } \\
\text { Coletivização }\end{array}$ & & Pessoalização - Determinação \\
& & & - Associação \\
\hline
\end{tabular}

Essa é uma manifestação plural de lideranças, de atores sociais, políticos, inclusive, mas principalmente de atores sociais.

\begin{tabular}{|l|l|l|l|}
\hline & Essa & é & $\begin{array}{l}\text { uma manifestação plural de lideranças, de } \\
\text { atores sociais, políticos, inclusive, mas }\end{array}$ \\
\hline
\end{tabular}




\begin{tabular}{|l|l|l|l|}
\hline & & & principalmente de atores sociais. \\
\hline Transitividade & Portador & $\begin{array}{l}\text { Proc. } \\
\text { Relacional }\end{array}$ & Atributo \\
\hline Sistema de Modo & Sujeito & $\begin{array}{l}\text { Finito + } \\
\text { Predicador }\end{array}$ & Complemento \\
\hline Ator Social & & & $\begin{array}{l}\text { Determinação - Categorização - } \\
\text { Funcionalização }\end{array}$ \\
\hline
\end{tabular}

Eu lamento a falta de reflexão diante dessas manifestações.

\begin{tabular}{|l|l|l|l|}
\hline & Eu & lamento & $\begin{array}{l}\text { a falta de reflexão diante dessas } \\
\text { manifestações. }\end{array}$ \\
\hline Transitividade & Experienciador & $\begin{array}{l}\text { Proc. Mental } \\
\text { emotivo }\end{array}$ & Fenômeno \\
\hline Sistema de Modo & Sujeito & Finito + Predicador & Complemento \\
\hline Ator Social & & & $\begin{array}{l}\text { Exclusão - Supressão } \\
\text { Impessoalização - Assimilação - } \\
\text { Coletivização }\end{array}$ \\
\hline
\end{tabular}

E a população, com razão, começa a questionar essas obras faraônicas, enquanto a agenda básica da sociedade está sobrestada.

\begin{tabular}{|l|l|l|l|l|l|}
\hline & E a população, & com razão, & $\begin{array}{l}\text { começa a } \\
\text { questionar }\end{array}$ & $\begin{array}{l}\text { essas obras } \\
\text { faraônicas, }\end{array}$ & $\begin{array}{l}\text { enquanto a agenda } \\
\text { básica da sociedade } \\
\text { está sobrestada. }\end{array}$ \\
& & & & & \\
\hline
\end{tabular}




\begin{tabular}{|l|l|l|l|l|l|} 
Transitividade & Dizente & Circunstância & Proc. Verbal & Verbiagem & Circunstância \\
\hline $\begin{array}{l}\text { Sistema de } \\
\text { Modo }\end{array}$ & Sujeito & $\begin{array}{l}\text { Adj. } \\
\text { Comentário }\end{array}$ & $\begin{array}{l}\text { Finito + } \\
\text { Predicador }\end{array}$ & Complemento & Adj. Modo \\
\hline Ator Social & $\begin{array}{l}\text { Inclusão - Ativação } \\
\text { - Impessoalização - } \\
\text { Assimilação - } \\
\text { Coletivização }\end{array}$ & & & & $\begin{array}{l}\text { Inclusão - Passivação } \\
\text { - Impessoalização - } \\
\text { Assimilação - } \\
\text { Coletivização }\end{array}$ \\
\hline
\end{tabular}

Há um projeto aqui sobre isso, e eu acho que além da Comissão Geral, que foi sugerida na reunião de Líderes para quarta-feira, para ouvirmos os reclamos da sociedade, precisamos também estabelecer uma agenda mínima.

\begin{tabular}{|c|c|c|c|c|c|}
\hline & Há & $\begin{array}{l}\text { um projeto } \\
\text { aqui sobre } \\
\text { isso }\end{array}$ & $\mathrm{e}$ & eu & acho \\
\hline Transitividade & \begin{tabular}{|l|} 
Proc. \\
Existencial
\end{tabular} & Existente & Conjunção & Experienciador & $\begin{array}{l}\text { Proc. Mental } \\
\text { Cognitivo }\end{array}$ \\
\hline Sistema de Modo & $\begin{array}{l}\text { Finito }+ \\
\text { Predicador }\end{array}$ & Sujeito & Conjunção & Sujeito & $\begin{array}{l}\text { Finito + } \\
\text { Predicador }\end{array}$ \\
\hline Ator Social & & & & & \\
\hline
\end{tabular}

\begin{tabular}{|c|c|c|c|c|c|}
\hline & \begin{tabular}{|l} 
que além da \\
Comissão Geral, \\
que foi sugerida na \\
reunião de Líderes \\
para quarta-feira, \\
para ouvirmos os \\
reclamos da \\
sociedade,
\end{tabular} & precisamos & também & estabelecer & $\begin{array}{l}\text { uma agenda } \\
\text { mínima. }\end{array}$ \\
\hline Transitividade & Fenômeno & & & Proc. Material & Meta \\
\hline
\end{tabular}




\begin{tabular}{|l|l|l|l|l|l|} 
& & & & Criativo & \\
\hline $\begin{array}{l}\text { Sistema de } \\
\text { Modo }\end{array}$ & Complemento & $\begin{array}{l}\text { Modulação } \\
\text { obrigação }\end{array}$ & $\begin{array}{l}\text { Adj. } \\
\text { comentário }\end{array}$ & $\begin{array}{l}\text { Finito + } \\
\text { Predicador }\end{array}$ & Complemento \\
\hline Ator Social & $\begin{array}{l}\text { Inclusão - Ativação } \\
\text { - Impessoalização - } \\
\text { Assimilação - } \\
\text { Coletivização }\end{array}$ & & & & \\
\hline
\end{tabular}

Acho que esta Casa, esta Câmara dos Deputados precisa imediatamente associar-se ao povo brasileiro nessas reclamações lícitas que ele está levando às ruas.

\begin{tabular}{|l|l|l|l|l|}
\hline & Acho & $\begin{array}{l}\text { que esta Casa, esta } \\
\text { Câmara dos } \\
\text { Deputados }\end{array}$ & precisa & imediatamente \\
\hline Transitividade & $\begin{array}{l}\text { Proc. Mental } \\
\text { cognitivo }\end{array}$ & Fenômeno & Adjunto \\
\hline Sistema de Modo & Modalização & $\begin{array}{l}\text { Modulação } \\
\text { obrigação }\end{array}$ & Adj. comentário \\
\hline Ator Social & & $\begin{array}{l}\text { Inclusão - } \\
\text { Ativação - } \\
\text { Impessoalização - } \\
\text { Objetivação - } \\
\text { Espacialização }\end{array}$ & & \\
\hline
\end{tabular}

\begin{tabular}{|l|l|l|}
\hline & associar-se & $\begin{array}{l}\text { ao povo brasileiro nessas reclamações lícitas que ele } \\
\text { está levando às ruas. }\end{array}$ \\
\hline Transitividade & Processo Material & Meta \\
\hline Sistema de Modo & Finito + Predicador & Complemento \\
\hline
\end{tabular}




\begin{tabular}{|l|l|l|} 
Ator Social & $\begin{array}{l}\text { Inclusão - Passivação - Beneficiação - } \\
\text { Impessoalização - Assimilação -Coletivização }\end{array}$ \\
\hline
\end{tabular}

\section{O SR. CARLOS SAMPAIO (PSDB-SP. Como Líder)}

Este é um movimento em que pese difuso, este é um movimento em que pese disperso, este é um movimento sem dúvida de indignação.

\begin{tabular}{|l|l|l|l|l|}
\hline & Este & é & um movimento & em que pese difuso, \\
\hline Transitividade & Portador & $\begin{array}{l}\text { Proc. } \\
\text { Relacional }\end{array}$ & Atributo & Circunstância \\
\hline Sistema de Modo & Sujeito & $\begin{array}{l}\text { Finito + } \\
\text { Predicador }\end{array}$ & Complemento & Adj. Modo \\
\hline Ator Social & & & $\begin{array}{l}\text { Inclusão - } \\
\text { Impessoalização - } \\
\text { Assimilação - } \\
\text { Coletivização. }\end{array}$ & \\
\hline
\end{tabular}

\begin{tabular}{|l|l|l|l|l|}
\hline & Este & é & um movimento & em que pese disperso, \\
\hline Transitividade & Portador & $\begin{array}{l}\text { Proc. } \\
\text { Relacional }\end{array}$ & Atributo & Circunstância \\
\hline Sistema de Modo & Sujeito & $\begin{array}{l}\text { Finito + } \\
\text { Predicador }\end{array}$ & Complemento & Adj. Modo \\
\hline Ator Social & & & $\begin{array}{l}\text { Inclusão - } \\
\text { Impessoalização - } \\
\text { Assimilação - } \\
\text { Coletivização. }\end{array}$ & \\
\hline
\end{tabular}




\begin{tabular}{|l|l|l|l|l|l|}
\hline & Este & é & um movimento & sem dúvida & de indignação. \\
\hline Transitividade & Portador & $\begin{array}{l}\text { Proc. } \\
\text { Relacional }\end{array}$ & Atributo & Circunstância & Complemento \\
\hline $\begin{array}{l}\text { Sistema de } \\
\text { Modo }\end{array}$ & Sujeito & $\begin{array}{l}\text { Finito + } \\
\text { Predicador }\end{array}$ & Complemento & $\begin{array}{l}\text { Adj. } \\
\text { Comentário }\end{array}$ & Complemento \\
\hline Ator Social & & & $\begin{array}{l}\text { Inclusão - } \\
\text { Impessoalização - } \\
\text { Assimilação - } \\
\text { Coletivização. }\end{array}$ & & \\
\hline
\end{tabular}

Existe um sentimento da Nação, e este sentimento da Nação cabe a nós como Parlamentares percebê-lo.

\begin{tabular}{|c|c|c|c|c|}
\hline & Existe & $\begin{array}{l}\text { um sentimento da } \\
\text { Nação, }\end{array}$ & $\mathrm{e}$ & este sentimento da Nação \\
\hline Transitividade & $\begin{array}{l}\text { Proc. } \\
\text { Existencial }\end{array}$ & Existente & Conjunção & Fenômeno \\
\hline Sistema de Modo & $\begin{array}{l}\text { Finito }+ \\
\text { Predicador }\end{array}$ & Sujeito & Conjunção & \\
\hline Ator Social & & $\begin{array}{l}\text { Impessoalização - } \\
\text { Abstração }\end{array}$ & & Impessoalização - Abstração \\
\hline
\end{tabular}

\begin{tabular}{|l|l|l|l|}
\hline & cabe & $\begin{array}{l}\text { a nós como } \\
\text { Parlamentares }\end{array}$ & percebê-lo. \\
\hline Transitividade & & Experienciador & Proc. Mental cognitivo \\
\hline
\end{tabular}




\begin{tabular}{|l|l|l|l|} 
Sistema de Modo & Modulação & Sujeito & Finito + Predicador \\
\hline Ator Social & & $\begin{array}{l}\text { Pessoalização - } \\
\text { Determinação - } \\
\text { Categorização - } \\
\text { Funcionalização }\end{array}$ & \\
& & & \\
\hline
\end{tabular}

Eu penso que é hora de o Parlamento saber escutar este pulsar das ruas, esses movimentos que acontecem não sem uma razão de ser.

\begin{tabular}{|l|l|l|l|}
\hline & Eu & penso & $\begin{array}{l}\text { que é hora de o Parlamento saber escutar } \\
\text { este pulsar das ruas, esses movimentos que } \\
\text { acontecem não sem uma razão de ser. }\end{array}$ \\
\hline Transitividade & Experienciador & $\begin{array}{l}\text { Proc. Mental } \\
\text { Cognitivo }\end{array}$ & Fenômeno \\
\hline Sistema de Modo & \multicolumn{2}{|l|}{ Modalização probabilidade } & \\
\hline Ator Social & & & $\begin{array}{l}\text { Impessoalização - Objetivação - } \\
\text { Somatização }\end{array}$ \\
\hline
\end{tabular}

Ninguém tem o direito de se apoderar deste movimento.

\begin{tabular}{|l|l|l|l|}
\hline & Ninguém & tem & o direito de se apoderar deste movimento. \\
\hline Transitividade & Possuidor & $\begin{array}{l}\text { Proc. } \\
\text { Relacional }\end{array}$ & Possuído \\
\hline Sistema de Modo & Sujeito & $\begin{array}{l}\text { Finito + } \\
\text { Predicador }\end{array}$ & Complemento \\
\hline Ator Social & & & $\begin{array}{l}\text { Impessoalização - Assimilação - } \\
\text { Coletivização. }\end{array}$ \\
\hline
\end{tabular}


O movimento é de indignação geral contra todos e contra toda a classe política.

\begin{tabular}{|l|l|l|l|}
\hline & O movimento & é & $\begin{array}{l}\text { de indignação geral contra todos e contra } \\
\text { toda a classe política. }\end{array}$ \\
\hline Transitividade & Portador & $\begin{array}{l}\text { Proc. } \\
\text { Relacional }\end{array}$ & Atributo \\
\hline Sistema de Modo & Sujeito & $\begin{array}{l}\text { Finito }+ \\
\text { Predicador }\end{array}$ & Complemento \\
\hline Ator Social & $\begin{array}{l}\text { Impessoalização } \\
- \text { Assimilação }- \\
\text { Coletivização }\end{array}$ & & $\begin{array}{l}\text { Pessoalização - Determinação - } \\
\text { Categorização - Funcionalização. }\end{array}$ \\
\hline
\end{tabular}

A luta em defesa da PEC 37 não é uma luta contra o Ministério Público, é uma luta contra a Nação.

\begin{tabular}{|l|l|l|l|l|}
\hline & $\begin{array}{l}\text { A luta em } \\
\text { defesa da PEC } \\
37\end{array}$ & não & é & $\begin{array}{l}\text { uma luta contra o Ministério } \\
\text { Público }\end{array}$ \\
\hline Transitividade & Portador & & $\begin{array}{l}\text { Proc. } \\
\text { Relacional }\end{array}$ & Atributo \\
\hline Sistema de Modo & Sujeito & Polaridade & $\begin{array}{l}\text { Finito }+ \\
\text { Predicador }\end{array}$ & Complemento \\
\hline Ator Social & & & Objetivação - espacialização \\
\hline
\end{tabular}

\begin{tabular}{|l|l|l|}
\hline & é & uma luta contra a Nação. \\
\hline Transitividade & $\begin{array}{l}\text { Proc. } \\
\text { Relacional }\end{array}$ & Atributo \\
\hline
\end{tabular}




\begin{tabular}{|l|l|l|} 
Sistema de Modo & $\begin{array}{l}\text { Finito }+ \\
\text { Predicador }\end{array}$ & Complemento \\
\hline Ator Social & & Impessoalização - Abstração \\
\hline
\end{tabular}

Se nós não soubermos sentir a Nação, se não for para ecoar nesta Casa o pensamento de quem nós representamos, este Congresso valor nenhum tem.

\begin{tabular}{|c|c|c|c|c|c|}
\hline & $\mathrm{Se}$ & nós & não & soubermos & sentir a Nação \\
\hline Transitividade & & Experienciador & & Proc. Mental & Fenômeno \\
\hline Sistema de Modo & Conjunção & Sujeito & Polaridade & $\begin{array}{l}\text { Finito + } \\
\text { Predicador }\end{array}$ & Complemento \\
\hline Ator Social & & & & & $\begin{array}{l}\text { Impessoalização - } \\
\text { Abstração }\end{array}$ \\
\hline
\end{tabular}

\begin{tabular}{|l|l|l|l|l|}
\hline & se & não & for & $\begin{array}{l}\text { para ecoar nesta Casa o } \\
\text { pensamento de quem nós } \\
\text { representamos, }\end{array}$ \\
\hline Transitividade & & & $\begin{array}{l}\text { Proc. } \\
\text { Relacional }\end{array}$ & Circunstância \\
\hline Sistema de Modo & Conjunção & Polaridade & $\begin{array}{l}\text { Finito + } \\
\text { Predicador }\end{array}$ & Adj. Modo \\
\hline Ator Social & & & & Pessoalização - \\
indeterminação
\end{tabular}

\begin{tabular}{|l|l|l|l|}
\hline & este Congresso & valor nenhum & tem. \\
\hline
\end{tabular}




\begin{tabular}{|l|l|l|l|} 
Transitividade & Possuidor & Possuído & Proc. Relacional \\
\hline Sistema de Modo & Sujeito & Complemento & Finito + Predicador \\
\hline Ator Social & $\begin{array}{l}\text { Impessoalização - } \\
\text { Objetivação - } \\
\text { Espacialização. }\end{array}$ & & \\
\hline
\end{tabular}

Srs., se continuarmos achando que esses movimentos são contra o Governo do Estado A ou B (palmas nas galerias) ou contra o Governo Federal, nós vamos estar colocando uma venda em nossos olhos e não estaremos a perceber que a indignação é generalizada e estamos todos na vala comum.

\begin{tabular}{|c|c|c|c|c|}
\hline & Srs., & $\begin{array}{l}\text { se continuarmos } \\
\text { achando que } \\
\text { esses } \\
\text { movimentos são } \\
\text { contra o } \\
\text { Governo do } \\
\text { Estado A ou B } \\
\text { (palmas nas } \\
\text { galerias) ou } \\
\text { contra o } \\
\text { Governo } \\
\text { Federal, }\end{array}$ & nós & vamos estar colocando \\
\hline Transitividade & & Circunstância & Ator & Proc. Material \\
\hline Sistema de Modo & Vocativo & Adj. Modo & Sujeito & Finito + Predicador \\
\hline Ator Social & & $\begin{array}{l}\text { Inclusão - } \\
\text { Ativação - } \\
\text { Pessoalização - } \\
\text { Determinação - } \\
\text { Associação }\end{array}$ & & \\
\hline
\end{tabular}




\begin{tabular}{|l|l|l|l|l|}
\hline & $\begin{array}{l}\text { uma venda em } \\
\text { nossos olhos }\end{array}$ & e & não & estaremos a perceber \\
\hline Transitividade & Meta & conjunção & & Proc. Mental Cognitivo \\
\hline Sistema de Modo & Complemento & conjunção & Polaridade & Finito + Predicador \\
\hline Ator Social & & & & \\
\hline
\end{tabular}

\begin{tabular}{|l|l|}
\hline & que a indignação é generalizada e estamos todos na vala comum. \\
\hline Transitividade & Fenômeno \\
\hline $\begin{array}{l}\text { Sistema de } \\
\text { Modo }\end{array}$ & Complemento \\
\hline Ator Social & Exclusão- encobrimento \\
\hline
\end{tabular}

Nós só mudaremos a visão que têm da gente com postura, postura política, com decisão acertada, e que corresponda aos anseios da Nação.

\begin{tabular}{|l|l|l|l|l|}
\hline & Nós & só & mudaremos & a visão que têm da gente \\
\hline Transitividade & Ator & & Proc. Material & Meta \\
\hline Sistema de Modo & Sujeito & Adj. Modo & $\begin{array}{l}\text { Finito + } \\
\text { Predicador }\end{array}$ & Complemento \\
\hline Ator Social & & & & Exclusão- Supressão \\
\hline
\end{tabular}

\begin{tabular}{|l|l|}
\hline & com postura, postura política, com decisão acertada, e que corresponda aos \\
\hline
\end{tabular} 


\begin{tabular}{|l|l|}
\hline & anseios da Nação. \\
\hline Transitividade & Circunstância \\
\hline $\begin{array}{l}\text { Sistema de } \\
\text { Modo }\end{array}$ & Adj. Modo \\
\hline Ator Social & Impessoalização - Abstração \\
\hline
\end{tabular}

Eu clamo aos colegas Parlamentares: façamos um momento de reflexão para sabermos de nossos próprios erros e, a partir de agora, andemos em consonância com o sentimento da Nação.

\begin{tabular}{|l|l|l|l|l|}
\hline & Eu & clamo & $\begin{array}{l}\text { aos colegas } \\
\text { Parlamentares: }\end{array}$ & $\begin{array}{l}\text { façamos um momento de } \\
\text { reflexão para sabermos de } \\
\text { nossos próprios erros e, a } \\
\text { partir de agora, andemos em } \\
\text { consonância com o } \\
\text { sentimento da Nação. }\end{array}$ \\
\hline Transitividade & Dizente & Proc. Verbal & Receptor & Verbiagem \\
\hline Sistema de Modo & Sujeito & $\begin{array}{l}\text { Finito + } \\
\text { Predicador }\end{array}$ & Complemento & Complemento \\
\hline Ator Social & & & Pessoalização - & Impessoalização - Abstração \\
\hline
\end{tabular}

\section{O SR. BETO ALBUQUERQUE (PSB-RS. Como Líder)}

Eu preciso, em nome do Partido Socialista Brasileiro, também expressar preocupações e convicções com relação ao movimento legítimo que faz com que as ruas, as avenidas das cidades brasileiras comecem a falar, porque, talvez, não estejam sendo ouvidas onde devam ser ouvidas. 


\begin{tabular}{|l|l|l|l|l|l|}
\hline & Eu & preciso & $\begin{array}{l}\text { em nome do } \\
\text { Partido } \\
\text { Socialista } \\
\text { Brasileiro, }\end{array}$ & também & expressar \\
\hline Transitividade & Dizente & & & & Proc. Verbal \\
\hline Sistema de Modo & Sujeito & Finito & Adj. comentário & Adj. Modo & Predicador \\
\hline Ator Social & & & & & \\
\hline
\end{tabular}

\begin{tabular}{|c|c|c|c|c|c|c|}
\hline & $\begin{array}{l}\text { preocupações e } \\
\text { convicções com } \\
\text { relação ao } \\
\text { movimento } \\
\text { legítimo }\end{array}$ & que & faz & $\begin{array}{l}\text { com que as ruas, as } \\
\text { avenidas das } \\
\text { cidades brasileiras }\end{array}$ & $\begin{array}{l}\text { lomecem a } \\
\text { falar, }\end{array}$ & $\begin{array}{l}\text { porque, talvez, } \\
\text { não estejam } \\
\text { sendo ouvidas } \\
\text { onde devam seı } \\
\text { ouvidas. }\end{array}$ \\
\hline Transitividade & Verbiagem & Ator & $\begin{array}{l}\text { Proc. } \\
\text { Material }\end{array}$ & Meta & Proc. Verbal & Circunstância \\
\hline $\begin{array}{l}\text { Sistema de } \\
\text { Modo }\end{array}$ & Complemento & & $\begin{array}{l}\text { Finito + } \\
\text { Predicador }\end{array}$ & Sujeito & $\begin{array}{l}\text { Finito + } \\
\text { Predicador }\end{array}$ & Adj. Modo \\
\hline Ator Social & $\begin{array}{l}\text { Impessoalização } \\
\text { - Assimilação - } \\
\text { Coletivização. }\end{array}$ & & & $\begin{array}{l}\text { Inclusão - } \\
\text { Ativação - } \\
\text { Impessoalização - } \\
\text { objetivação - } \\
\text { espacialização }\end{array}$ & & \\
\hline
\end{tabular}

Este é um movimento que quer ser ouvido. 


\begin{tabular}{|l|l|l|l|}
\hline & Este & é & um movimento que quer ser ouvido. \\
\hline Transitividade & Portador & Proc. Relacional & Atributo \\
\hline Sistema de Modo & Sujeito & $\begin{array}{l}\text { Finito }+ \\
\text { Predicador }\end{array}$ & Complemento \\
\hline Ator Social & & & $\begin{array}{l}\text { Impessoalização - Assimilação - } \\
\text { Coletivização. }\end{array}$ \\
\hline
\end{tabular}

É um movimento que cresce em razão de múltiplas insatisfações.

\begin{tabular}{|c|c|c|c|}
\hline & É & $\begin{array}{l}\text { um movimento que } \\
\text { cresce }\end{array}$ & $\begin{array}{l}\text { em razão de múltiplas } \\
\text { insatisfações. }\end{array}$ \\
\hline Transitividade & $\begin{array}{l}\text { Proc. } \\
\text { Relacional }\end{array}$ & Atributo & Circunstância \\
\hline Sistema de Modo & $\begin{array}{l}\text { Finito }+ \\
\text { Predicador }\end{array}$ & Complemento & Adj. Modo \\
\hline Ator Social & & $\begin{array}{l}\text { Impessoalização - } \\
\text { Assimilação - } \\
\text { Coletivização. }\end{array}$ & \\
\hline
\end{tabular}

É a voz das ruas que está pedindo para ser ouvida.

\begin{tabular}{|l|l|l|l|l|l|}
\hline & É & a voz das ruas & que & está pedindo & para ser ouvida. \\
\hline Transitividade & & Dizente & & Proc. Verbal & Verbiagem \\
\hline Sistema de Modo & Expletivo & Sujeito & Expletivo & $\begin{array}{l}\text { Finito + } \\
\text { Predicador }\end{array}$ & Complemento \\
\hline Ator Social & & $\begin{array}{l}\text { Impessoalização - } \\
\text { objetivação - } \\
\text { espacialização }\end{array}$ & & & \\
\hline
\end{tabular}

Nós precisamos ouvir esta sociedade, organizada ou não, ela precisa ser ouvida. 


\begin{tabular}{|l|l|l|l|l|}
\hline & Nós & precisamos & ouvir & $\begin{array}{l}\text { esta sociedade, organizada } \\
\text { ou não, ela precisa ser } \\
\text { ouvida. }\end{array}$ \\
\hline Transitividade & Experienciador & & $\begin{array}{l}\text { Proc. Mental } \\
\text { Perceptivo }\end{array}$ & Fenômeno \\
\hline Sistema de Modo & Sujeito & $\begin{array}{l}\text { Modulação } \\
\text { obrigação }\end{array}$ & Finito + Predicador & Complemento \\
\hline Ator Social & & & & $\begin{array}{l}\text { Impessoalização - } \\
\text { Assimilação -Coletivização }\end{array}$ \\
\hline
\end{tabular}

Eles não querem ser sardinha dentro de ônibus.

\begin{tabular}{|l|l|l|l|l|}
\hline & Eles & não & querem & $\begin{array}{l}\text { ser sardinha dentro de } \\
\text { ônibus. }\end{array}$ \\
\hline Transitividade & Experienciador & & $\begin{array}{l}\text { Proc. Mental } \\
\text { desiderativo }\end{array}$ & Fenômeno \\
\hline Sistema de Modo & Sujeito & Polaridade & $\begin{array}{l}\text { Finito }+ \\
\text { Predicador }\end{array}$ & Complemento \\
\hline Ator Social & & & & \\
\hline
\end{tabular}

Eles não querem ser assaltados dentro de ônibus.

\begin{tabular}{|l|l|l|l|l|}
\hline & Eles & não & querem & $\begin{array}{l}\text { ser assaltados dentro de } \\
\text { ônibus. }\end{array}$ \\
\hline Transitividade & Experienciador & & $\begin{array}{l}\text { Proc. Mental } \\
\text { desiderativo }\end{array}$ & Fenômeno \\
\hline Sistema de Modo & Sujeito & Polaridade & Finito + & Complemento \\
\hline
\end{tabular}




\begin{tabular}{|l|l|l|l|l|} 
& & & Predicador & \\
\hline Ator Social & & & & \\
\hline
\end{tabular}

O povo quer regularidade no transporte.

\begin{tabular}{|l|l|l|l|}
\hline & O povo & quer & regularidade no transporte. \\
\hline Transitividade & Experienciador & Proc. Mental desiderativo & Fenômeno \\
\hline Sistema de Modo & Sujeito & Finito + Predicador & Complemento \\
\hline Ator Social & $\begin{array}{l}\text { Impessoalização } \\
- \text { Assimilação - } \\
\text { Coletivização }\end{array}$ & & \\
\hline
\end{tabular}

É hora de fazermos a nossa parte, olharmos para as pautas do Governo, sim, mas olharmos muito mais para as pautas do povo, que nem sempre estão presentes neste plenário, nas nossas deliberações.

\begin{tabular}{|l|l|l|l|}
\hline & É hora de & fazermos & $\begin{array}{l}\text { a nossa parte, olharmos para as pautas do } \\
\text { Governo, sim, mas olharmos muito mais para as } \\
\text { pautas do povo, que nem sempre estão presentes } \\
\text { neste plenário, nas nossas deliberações. }\end{array}$ \\
\hline Transitividade & $\begin{array}{l}\text { Circunstância } \\
\text { de tempo }\end{array}$ & $\begin{array}{l}\text { Proc. } \\
\text { Material } \\
\text { Criativo }\end{array}$ & Meta \\
\hline Sistema de Modo & Adj. Modo & $\begin{array}{l}\text { Finito + } \\
\text { Predicador }\end{array}$ & Complemento \\
\hline Ator Social & & & Pessoalização - Determinação - Diferenciação \\
\hline
\end{tabular}




\section{O SR. ANTHONY GAROTINHO (Bloco/PR-RJ. Como Líder)}

As pessoas colocaram para fora muitas frustrações que precisavam colocar e desejavam colocar, e não tinham canal para colocar.

\begin{tabular}{|l|l|l|l|}
\hline & As pessoas & $\begin{array}{l}\text { colocaram para } \\
\text { fora }\end{array}$ & $\begin{array}{l}\text { muitas frustrações que precisavam colocar } \\
\text { e desejavam colocar, e não tinham canal } \\
\text { para colocar. }\end{array}$ \\
\hline Transitividade & Dizente & Proc. Verbal & Verbiagem \\
\hline Sistema de Modo & Sujeito & $\begin{array}{l}\text { Finito + } \\
\text { Predicador }\end{array}$ & Complemento \\
\hline Ator Social & $\begin{array}{l}\text { Inclusão- Ativação - } \\
\text { Assimilação - } \\
\text { Coletivização }\end{array}$ & & \\
\hline
\end{tabular}

Ontem o povo dizia: "Fora, Rede Globo".

\begin{tabular}{|l|l|l|l|l|}
\hline & Ontem & o povo & dizia: & "Fora, Rede Globo". \\
\hline Transitividade & $\begin{array}{l}\text { Circunstância } \\
\text { de tempo }\end{array}$ & Dizente & $\begin{array}{l}\text { Processo } \\
\text { Verbal }\end{array}$ & Verbiagem \\
\hline Sistema de Modo & Adj. Modo & Sujeito & $\begin{array}{l}\text { Finito + } \\
\text { Predicador }\end{array}$ & Complemento \\
\hline Ator Social & & $\begin{array}{l}\text { Inclusão- Ativação - } \\
\text { Impessoalização- } \\
\text { Assimilação - } \\
\text { Coletivização }\end{array}$ & $\begin{array}{l}\text { Inclusão- Passivação- } \\
\text { Nomeaçização- Determinação- }\end{array}$ \\
\hline
\end{tabular}

A sociedade parece que quer dar um passo adiante.

\begin{tabular}{|l|l|l|l|l|}
\hline & A sociedade & parece & que quer dar & um passo adiante. \\
\hline
\end{tabular}




\begin{tabular}{|l|l|l|l|l|} 
Transitividade & Experienciador & $\begin{array}{l}\text { Proc. Mental } \\
\text { Desiderativo }\end{array}$ & Fenômeno \\
\hline $\begin{array}{l}\text { Sistema de } \\
\text { Modo }\end{array}$ & Sujeito & Modalização & Finito + Predicador & Complemento \\
\hline Ator Social & $\begin{array}{l}\text { Inclusão- Ativação - } \\
\text { Impessoalização- } \\
\text { Assimilação - } \\
\text { Coletivização }\end{array}$ & & & \\
\hline
\end{tabular}

A sociedade parece que está dizendo que quer ir para a democracia participativa.

\begin{tabular}{|c|c|c|c|c|}
\hline & A sociedade & parece & que está dizendo & $\begin{array}{l}\text { que quer ir para a } \\
\text { democracia } \\
\text { participativa. }\end{array}$ \\
\hline Transitividade & Dizente & & Proc. Verbal & Verbiagem \\
\hline Sistema de Modo & Sujeito & Modalização & $\begin{array}{l}\text { Finito + } \\
\text { Predicador }\end{array}$ & Complemento \\
\hline Ator Social & $\begin{array}{l}\text { Inclusão- Ativação - } \\
\text { Impessoalização- } \\
\text { Assimilação - } \\
\text { Coletivização }\end{array}$ & & & \\
\hline
\end{tabular}

Dizer que aquelas pessoas são baderneiras, dizer que é uma luta sem causa ou fazer qualquer afirmação conspiratória neste momento seria precipitado por parte de qualquer pessoa.

\begin{tabular}{|l|l|l|l|}
\hline & $\begin{array}{l}\text { Dizer que aquelas } \\
\text { pessoas são } \\
\text { baderneiras, dizer que }\end{array}$ & seria & $\begin{array}{l}\text { precipitado por parte de qualquer } \\
\text { pessoa. }\end{array}$ \\
\hline
\end{tabular}




\begin{tabular}{|l|l|l|l|}
\hline & $\begin{array}{l}\text { é uma luta sem causa } \\
\text { ou fazer qualquer } \\
\text { afirmação } \\
\text { conspiratória neste } \\
\text { momento }\end{array}$ & & \\
\hline Transitividade & Portador & Proc. Relacional & Atributo \\
\hline Sistema de Modo & Sujeito & $\begin{array}{l}\text { Finito + } \\
\text { Predicador }\end{array}$ & Complemento \\
\hline Ator Social & Exclusão do agente & & \\
\hline
\end{tabular}

O povo, ontem, estava revoltado, porque sabe que o 1,2 bilhão de reais gastos no Maracanã é o dinheiro que está faltando na escola, no hospital, no posto de saúde.

\begin{tabular}{|l|l|l|l|l|l|}
\hline & O povo, & ontem, & estava & revoltado, & $\begin{array}{l}\text { porque sabe que } \\
\text { o 1,2 bilhão de } \\
\text { reais gastos no } \\
\text { Maracanã é o } \\
\text { dinheiro que está } \\
\text { faltando na } \\
\text { escola, no } \\
\text { hospital, no } \\
\text { posto de saúde. }\end{array}$ \\
\hline Transitividade & Portador & Circunstância & Proc. \\
Relacional & Atributo & Circunstância \\
\hline Modo & Sujeito & Adj. Modo & Finito + \\
Predicador & Complemento & & Adj. Modo \\
\hline Ator Social & $\begin{array}{l}\text { Inclusão- Ativação - } \\
\text { Impessoalização- } \\
\text { Assimilação - } \\
\text { Coletivização }\end{array}$ & & & & \\
\hline
\end{tabular}


O povo que foi para as ruas sabe que aquele dinheiro todo que foi gasto em obra para turista na Zona Sul do Rio de Janeiro é o dinheiro que falta na Zona Norte, na Zona Oeste, nos bairros mais pobres, nas comunidades mais humildes.

\begin{tabular}{|l|l|l|l|}
\hline & $\begin{array}{l}\text { O povo que foi para } \\
\text { as ruas }\end{array}$ & sabe & $\begin{array}{l}\text { que aquele dinheiro todo que foi gasto em obra } \\
\text { para turista na Zona Sul do Rio de Janeiro é o } \\
\text { dinheiro que falta na Zona Norte, na Zona } \\
\text { Oeste, nos bairros mais pobres, nas } \\
\text { comunidades mais humildes. }\end{array}$ \\
\hline Transitividade & Experienciador & $\begin{array}{l}\text { Proc. Mental } \\
\text { Cognitivo }\end{array}$ & Fenômeno \\
\hline Sistema de & Sujeito & $\begin{array}{l}\text { Finito + } \\
\text { Implusão- Ativação - } \\
\text { Assimilação - } \\
\text { Coletivização }\end{array}$ & Complemento \\
\hline Ator Social & & & \\
\hline
\end{tabular}

Vejam que a força do povo é tão grande que, no Jornal Nacional de ontem, a Rede Globo praticamente pediu desculpas pela cobertura errônea que vinha dando ao movimento.

\begin{tabular}{|l|l|l|l|}
\hline & Vejam & $\begin{array}{l}\text { que a força do povo é } \\
\text { tão grande que, }\end{array}$ & no Jornal Nacional de ontem, \\
\hline Transitividade & $\begin{array}{l}\text { Proc. Mental } \\
\text { perceptivo }\end{array}$ & Fenômeno & Circunstância \\
\hline Sistema de Modo & $\begin{array}{l}\text { Finito + } \\
\text { Predicador }\end{array}$ & Complemento & Adj. Modo \\
\hline Ator Social & $\begin{array}{l}\text { Inclusão- Ativação - } \\
\text { Impessoalização- } \\
\text { Assimilação - } \\
\text { Coletivização }\end{array}$ & $\begin{array}{l}\text { Pessoalização - Determinação - } \\
\text { Nomeação }\end{array}$ \\
\hline
\end{tabular}




\begin{tabular}{|l|l|l|l|l|}
\hline & a Rede Globo & praticamente & pediu & $\begin{array}{l}\text { desculpas pela cobertura } \\
\text { errônea que vinha dando ao } \\
\text { movimento. }\end{array}$ \\
\hline Transitividade & Dizente & & Proc. Verbal & Verbiagem \\
\hline Sistema de Modo & Sujeito & Modalização & $\begin{array}{l}\text { Finito + } \\
\text { Predicador }\end{array}$ & Complemento \\
\hline Ator Social & $\begin{array}{l}\text { Pessoalização - } \\
\text { Determinação } \\
\text { Nomeação }\end{array}$ & & & $\begin{array}{l}\text { Imclusão - Passivação - } \\
\text { Assimilação - Coletivização. }\end{array}$ \\
\hline
\end{tabular}

\section{O SR. LUIS CARLOS HEINZE (PP-RS. Pela ordem)}

O povo está enxergando isso: a corrupção que existe hoje, seja no Executivo, seja dentro dos próprios colégios Legislativos, mas também há os corruptores. Temos que ver os empresários que corrompem os corruptos.

\begin{tabular}{|c|c|c|c|c|c|c|}
\hline & O povo & $\begin{array}{l}\text { está } \\
\text { enxergando }\end{array}$ & $\begin{array}{l}\text { isso: a corrupção } \\
\text { que existe hoje, } \\
\text { seja no } \\
\text { Executivo, seja } \\
\text { dentro dos } \\
\text { próprios colégios } \\
\text { Legislativos, }\end{array}$ & $\begin{array}{l}\text { mas } \\
\text { também }\end{array}$ & há & $\begin{array}{l}\text { os } \\
\text { corrupt } \\
\text { ores. }\end{array}$ \\
\hline Transitividade & Experienciador & $\begin{array}{l}\text { Proc. Mental } \\
\text { perceptivo }\end{array}$ & Fenômeno & Conjunção & \begin{tabular}{|l} 
Proc. \\
Existencial
\end{tabular} & Existente \\
\hline \begin{tabular}{|l} 
Sistema de \\
Modo
\end{tabular} & Sujeito & \begin{tabular}{|l} 
Finito + \\
Predicador
\end{tabular} & Complemento & Adj. Modo & $\begin{array}{l}\text { Finito + } \\
\text { Predicador }\end{array}$ & Sujeito \\
\hline Ator Social & $\begin{array}{l}\text { Inclusão- Ativação } \\
\text { Impessoalização- }\end{array}$ & & $\begin{array}{l}\text { Impessoalização } \\
\text { - objetivação - }\end{array}$ & & & \\
\hline
\end{tabular}


Assimilação -

espacialização

Coletivização

O povo está indo às ruas para mostrar a sua indignação, a sua insatisfação.

\begin{tabular}{|l|l|l|l|l|}
\hline & O povo & está indo & às ruas & $\begin{array}{l}\text { para mostrar a sua } \\
\text { indignação, a sua } \\
\text { insatisfação. }\end{array}$ \\
\hline Transitividade & Ator & Proc. Material & Meta & Circunstância \\
\hline Sistema de Modo & $\begin{array}{l}\text { Sujeito } \\
\text { Ator Social }\end{array}$ & $\begin{array}{l}\text { Finito + } \\
\text { Predicador } \\
\text { Impessoalização- } \\
\text { Assimilação - } \\
\text { Coletivização }\end{array}$ & Complemento & Adj. Modo \\
\hline
\end{tabular}

Então, nós temos que somar as vozes da rua com as vozes desta Casa, com as injustiças que se fazem, das promessas que fazem hoje.

\begin{tabular}{|l|l|l|l|l|l|}
\hline & Então, & nós & temos que & somar & $\begin{array}{l}\text { as vozes da rua com as } \\
\text { vozes desta Casa, com } \\
\text { as injustiças que se } \\
\text { fazem, das promessas } \\
\text { que fazem hoje. }\end{array}$ \\
\hline Transitividade & Conjunção & Ator & & $\begin{array}{l}\text { Proc. } \\
\text { Material }\end{array}$ & Meta \\
\hline Sistema de Modo & & Sujeito & $\begin{array}{l}\text { Modulação } \\
\text { obrigação }\end{array}$ & $\begin{array}{l}\text { Finito + } \\
\text { Predicador }\end{array}$ & Complemento \\
\hline Ator Social & & & & & impessoalização - \\
\hline
\end{tabular}




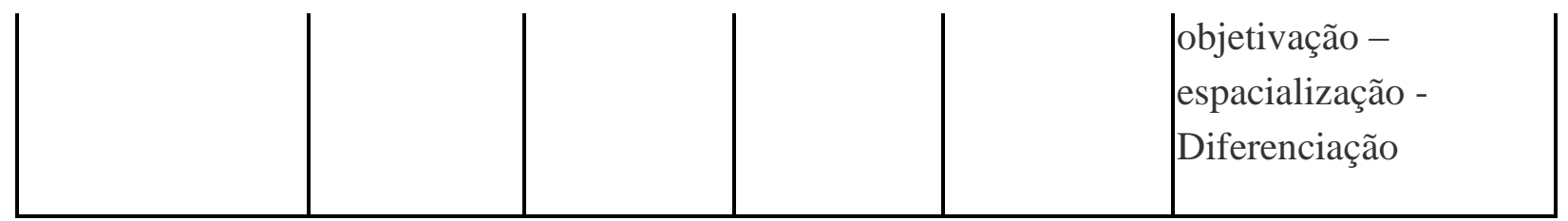

Nós vamos nos juntar, vamos nos somar às pessoas de bem, contra a corrupção, contra a sacanagem, contra a safadeza e, principalmente, contra as falsas promessas, porque tem alguém que tem que pagar essa conta.

\begin{tabular}{|c|c|c|c|c|}
\hline & Nós & $\begin{array}{l}\text { vamos nos } \\
\text { juntar }\end{array}$ & $\begin{array}{l}\text { vamos nos } \\
\text { somar }\end{array}$ & $\begin{array}{l}\text { às pessoas de bem, contra a } \\
\text { corrupção, contra a } \\
\text { sacanagem, contra a safadeza } \\
\text { e, principalmente, contra as } \\
\text { falsas promessas, porque tem } \\
\text { alguém que tem que pagar essa } \\
\text { conta. }\end{array}$ \\
\hline Transitividade & Ator & Proc. Material & Proc. Material & Meta \\
\hline Sistema de Modo & Sujeito & $\begin{array}{l}\text { Finito }+ \\
\text { Predicador }\end{array}$ & $\begin{array}{l}\text { Finito + } \\
\text { Predicador }\end{array}$ & Complemento \\
\hline Ator Social & & & & $\begin{array}{l}\text { Pessoalização - } \\
\text { indeterminação }\end{array}$ \\
\hline
\end{tabular}

Meus cumprimentos àqueles que, ordeiramente, sem partidarizar a questão, estão indo às ruas para protestar contra essa série de desmandos e falsas promessas que estão ocorrendo no nosso País.

\begin{tabular}{|l|l|l|}
\hline & $\begin{array}{l}\text { Meus } \\
\text { cumprimentos }\end{array}$ & $\begin{array}{l}\text { àqueles que, ordeiramente, sem partidarizar a questão, estão } \\
\text { indo às ruas para protestar contra essa série de desmandos e } \\
\text { falsas promessas que estão ocorrendo no nosso País. }\end{array}$ \\
\hline Transitividade & Meta & Beneficiário \\
\hline Sistema de Modo & & \\
\hline Ator Social & & Pessoalização - indeterminação \\
\hline
\end{tabular}


O SR. PRESIDENTE (Andre Vargas) (Resposta ao Deputado Luis Carlos Heinze)

Deputado Luis Carlos Heinze, sem polemizar, quero só avisar que acompanhei as manifestações.

\begin{tabular}{|l|l|l|l|l|}
\hline & $\begin{array}{l}\text { Deputado Luis } \\
\text { Carlos Heinze, }\end{array}$ & sem polemizar, & quero & só \\
\hline Transitividade & & & $\begin{array}{l}\text { Proc. Mental } \\
\text { Desiderativo }\end{array}$ & \\
\hline Sistema de Modo & Vocativo & Modalização & $\begin{array}{l}\text { Finito + } \\
\text { Predicador }\end{array}$ & Modalização \\
\hline Ator Social & $\begin{array}{l}\text { Pessoalização - } \\
\text { determinação - } \\
\text { Nomeação }\end{array}$ & & & \\
\hline
\end{tabular}

\begin{tabular}{|l|l|l|}
\hline & avisar & que acompanhei as manifestações. \\
\hline Transitividade & Proc. Verbal & Verbiagem \\
\hline Sistema de Modo & Finito + Predicador & Complemento \\
\hline Ator Social & & $\begin{array}{l}\text { Inclusão - passivação- Impessoalização- Assimilação- } \\
\text { Coletivização. }\end{array}$ \\
\hline
\end{tabular}

Houve manifestação contra a Rede Globo, houve manifestação a favor dos indígenas, há o debate sobre a questão dos direitos humanos.

\begin{tabular}{|l|l|l|l|l|}
\hline & Houve & $\begin{array}{l}\text { Manifestação } \\
\text { contra a Rede } \\
\text { Globo, }\end{array}$ & houve & $\begin{array}{l}\text { manifestação a favor dos } \\
\text { indígenas, }\end{array}$ \\
\hline Transitividade & Proc. & Existente & Proc. & Existente \\
\hline
\end{tabular}




\begin{tabular}{|c|c|c|c|c|}
\hline & Existencial & & Existencial & \\
\hline Sistema de Modo & $\begin{array}{l}\text { Finito + } \\
\text { Predicador }\end{array}$ & Complemento & $\begin{array}{l}\text { Finito + } \\
\text { Predicador }\end{array}$ & Complemento \\
\hline Ator Social & & $\begin{array}{l}\text { Impessoalização- } \\
\text { Assimilação- } \\
\text { Coletivização - } \\
\text { Diferenciação }\end{array}$ & & $\begin{array}{l}\text { Impessoalização- } \\
\text { Assimilação- Coletivização - } \\
\text { Diferenciação }\end{array}$ \\
\hline
\end{tabular}

\begin{tabular}{|l|l|l|}
\hline & há & o debate sobre a questão dos direitos humanos. \\
\hline Transitividade & Proc. Existencial & Existente \\
\hline Sistema de Modo & Finito + Predicador & Complemento \\
\hline Ator Social & & $\begin{array}{l}\text { Impessoalização- Assimilação- Coletivização - } \\
\text { Diferenciação }\end{array}$ \\
\hline
\end{tabular}

Sem polemizar, quero só levantar que nós precisamos ter muito cuidado em relação a isso.

\begin{tabular}{|l|l|l|l|l|l|}
\hline & Sem polemizar, & quero & só & levantar & $\begin{array}{l}\text { que nós precisamos } \\
\text { ter muito cuidado em } \\
\text { relação a isso. }\end{array}$ \\
\hline Transitividade & & $\begin{array}{l}\text { Proc. Mental } \\
\text { desiderativo }\end{array}$ & & Proc. Verbal & Verbiagem \\
\hline Sistema de Modo & Modalização & $\begin{array}{l}\text { Finito + } \\
\text { Predicador }\end{array}$ & Modalização & $\begin{array}{l}\text { Finito + } \\
\text { Predicador }\end{array}$ & Complemento \\
\hline Ator Social & & & & & \\
\hline
\end{tabular}




\section{O SR. JOSÉ HUMBERTO (Bloco/PHS-MG)}

O que talvez a gente não esperasse ou a maioria não esperasse é que a força dessas manifestações talvez tenha assustado a Nação brasileira, e talvez, sobretudo a classe política.

\begin{tabular}{|l|l|l|l|}
\hline & $\begin{array}{l}\text { O que talvez a } \\
\text { gente não } \\
\text { esperasse ou a } \\
\text { maioria não } \\
\text { esperasse }\end{array}$ & $\begin{array}{l}\text { a força dessas manifestações talvez tenha } \\
\text { assustado a Nação brasileira, e talvez, } \\
\text { sobretudo a classe política. }\end{array}$ \\
\hline Transitividade & Portador & $\begin{array}{l}\text { Proc. } \\
\text { Relacional }\end{array}$ & Atributo \\
\hline Sistema de Modo & $\begin{array}{l}\text { Sujeito + } \\
\text { Sistema de } \\
\text { Modo }\end{array}$ & $\begin{array}{l}\text { Finito + } \\
\text { Predicador }\end{array}$ & $\begin{array}{l}\text { Complemento } \\
\text { Ator Social }\end{array}$ \\
& & $\begin{array}{l}\text { Impessoalização- Assimilação- } \\
\text { Coletivização/Impessoalização - Abstração/ } \\
\text { Pessoalização - Determinação - } \\
\text { Categorização - Funcionalização. }\end{array}$ \\
\hline
\end{tabular}

O que acontece é que esse modelo que aí se encontra não vai ao encontro das aspirações de nossa população.

\begin{tabular}{|l|l|l|l|l|l|l|}
\hline & $\begin{array}{l}\text { O que } \\
\text { acontece }\end{array}$ & é que & $\begin{array}{l}\text { esse modelo } \\
\text { que aí se } \\
\text { encontra }\end{array}$ & não & vai & $\begin{array}{l}\text { ao encontro das } \\
\text { aspirações de nossa } \\
\text { população. }\end{array}$ \\
\hline Transitividade & & & Portador & & $\begin{array}{l}\text { Proc. } \\
\text { Relacional }\end{array}$ & Atributo \\
\hline Sistema de Modo & & & Sujeito & Polaridade & $\begin{array}{l}\text { Finito + } \\
\text { Predicador }\end{array}$ & complemento \\
\hline Ator Social & & & & & & $\begin{array}{l}\text { Impessoalização- } \\
\text { Assimilação- }\end{array}$ \\
\hline
\end{tabular}


A população não se sente representada e nós aqui temos dificuldade de fazer valer os nossos mandatos.

\begin{tabular}{|l|l|l|l|l|}
\hline & A população & não & se sente & representada \\
\hline Transitividade & Experienciador & & $\begin{array}{l}\text { Proc. Mental } \\
\text { emotivo }\end{array}$ & Fenômeno \\
\hline Sistema de Modo & Sujeito & Polaridade & $\begin{array}{l}\text { Finito + } \\
\text { Predicador }\end{array}$ & Complemento \\
\hline Ator Social & $\begin{array}{l}\text { Inclusão - Ativação } \\
\text { - Impessoalização } \\
\text { - Assimilação - } \\
\text { Coletivização }\end{array}$ & & dificuldade de fazer valer os nossos \\
mandatos. & \\
\hline Transitividade & Possuidor & $\begin{array}{l}\text { Proc. } \\
\text { Relacional }\end{array}$ & Possuído & \\
\hline Sistema de Modo & Sujeito & Finito + \\
& Predicador & Complemento & \\
\hline Ator Social & Pessoalização - & Determinação - \\
Diferenciação & & & \\
\hline
\end{tabular}

Tenho tido dificuldade de explicar à população que me elegeu tudo aquilo que é nossa atribuição e nossa função.

\begin{tabular}{|l|l|l|}
\hline & Tenho tido & dificuldade de explicar à população que me elegeu tudo \\
\hline
\end{tabular}




\begin{tabular}{|l|l|l|}
\hline & & aquilo que é nossa atribuição e nossa função. \\
\hline Transitividade & Proc. Relacional & Possuído \\
\hline Sistema de Modo & Finito + Predicador & Complemento \\
\hline Ator Social & & $\begin{array}{l}\text { Inclusão - Passivação - Impessoalização - Assimilação } \\
\text { Coletivização }\end{array}$ \\
\hline
\end{tabular}

O povo tem razão nas suas cobranças.

\begin{tabular}{|l|l|l|l|}
\hline & O povo & tem & razão nas suas cobranças. \\
\hline Transitividade & Possuidor & $\begin{array}{l}\text { Proc. } \\
\text { Relacional }\end{array}$ & Possuído \\
\hline Sistema de Modo & Sujeito & $\begin{array}{l}\text { Finito + } \\
\text { Predicador }\end{array}$ & Complemento \\
\hline Ator Social & $\begin{array}{l}\text { Inclusão - Ativação } \\
\text { - Impessoalização - } \\
\text { Assimilação - } \\
\text { Coletivização }\end{array}$ & \\
\hline
\end{tabular}

Nós temos que construir esse Brasil e é esse Brasil, é essa nação que o povo espera de nós.

\begin{tabular}{|l|l|l|l|l|}
\hline & Nós & temos que & construir & esse Brasil \\
\hline Transitividade & Ator & & Proc. Material & Meta \\
\hline Sistema de Modo & Sujeito & $\begin{array}{l}\text { Modulação } \\
\text { obrigação }\end{array}$ & $\begin{array}{l}\text { Finito + } \\
\text { Predicador }\end{array}$ & Complemento \\
\hline Ator Social & $\begin{array}{l}\text { Inclusão - } \\
\text { Ativação - }\end{array}$ & & & $\begin{array}{l}\text { Inclusão- Passivação - } \\
\text { Beneficiação - } \\
\text { Impessoalização - objetivação }\end{array}$ \\
\hline
\end{tabular}


Sujeição

- espacialização

\begin{tabular}{|c|c|c|c|c|}
\hline & $\begin{array}{l}\text { e é esse Brasil, é } \\
\text { essa nação }\end{array}$ & que o povo & espera & de nós. \\
\hline Transitividade & Meta & Ator & $\begin{array}{l}\text { Proc. } \\
\text { Material }\end{array}$ & Beneficiário \\
\hline $\begin{array}{l}\text { Sistema de } \\
\text { Modo }\end{array}$ & Complemento & Sujeito & $\begin{array}{l}\text { Finito }+ \\
\text { Predicador }\end{array}$ & Adj. Modo \\
\hline Ator Social & $\begin{array}{l}\text { Impessoalização - } \\
\text { objetivação - } \\
\text { espacialização/ } \\
\text { Impessoalização - } \\
\text { Abstração }\end{array}$ & $\begin{array}{l}\text { Inclusão - Passivação - } \\
\text { Beneficiação-Impessoalização - } \\
\text { Assimilação -Coletivização }\end{array}$ & & $\begin{array}{l}\text { Inclusão - } \\
\text { Ativação - } \\
\text { Sujeição }\end{array}$ \\
\hline
\end{tabular}

\section{O SR. DR. CARLOS ALBERTO (PMN-RJ)}

A minha defesa se estende a outros poderes constituídos de que não podemos agir como se fôssemos os donos da verdade, sem auscultar os reclamos da sociedade brasileira, as suas necessidades básicas, as suas carências, os seus anseios.

\begin{tabular}{|l|l|l|l|l|}
\hline & $\begin{array}{l}\text { A minha } \\
\text { defesa }\end{array}$ & se estende & a outros poderes constituídos & de que \\
\hline Transitividade & Ator & Proc. Material & Meta & \\
\hline Sistema de Modo & Sujeito & $\begin{array}{l}\text { Finito + } \\
\text { Predicador }\end{array}$ & Complemento & \\
\hline Ator Social & & & Impessoalização - Abstração & \\
\hline
\end{tabular}




\begin{tabular}{|l|l|l|l|}
\hline & não podemos & agir & $\begin{array}{l}\text { como se fôssemos os donos da verdade, sem } \\
\text { auscultar os reclamos da sociedade brasileira, } \\
\text { as suas necessidades básicas, as suas carências, } \\
\text { os seus anseios. }\end{array}$ \\
\hline Transitividade & & $\begin{array}{l}\text { Proc. } \\
\text { Material }\end{array}$ & Circunstância \\
\hline Sistema de Modo & Polaridade + & Finito + & Adj. Modo \\
Modulação & Predicador & & $\begin{array}{l}\text { Inclusão - Passivação - Impessoalização - } \\
\text { Assimilação - Coletivização }\end{array}$ \\
\hline
\end{tabular}

Leio nos jornais, nas revistas e vejo nas tevês que muitos estão surpresos com os movimentos recentes que vêm ocorrendo de segmentos da sociedade, em especial dos jovens, sob o mote de redução dos preços das passagens de ônibus e outros modais.

\begin{tabular}{|c|c|c|c|c|}
\hline & Leio & $\begin{array}{l}\text { nos jornais, nas } \\
\text { revistas e }\end{array}$ & vejo & nas tevês que \\
\hline Transitividade & $\begin{array}{l}\text { Proc. Mental } \\
\text { cognitivo }\end{array}$ & Circunstância & $\begin{array}{l}\text { Proc. Mental } \\
\text { perceptivo }\end{array}$ & Circunstância \\
\hline Sistema de Modo & $\begin{array}{l}\text { Finito + } \\
\text { Predicador }\end{array}$ & Adj. Modo & $\begin{array}{l}\text { Finito + } \\
\text { Predicador }\end{array}$ & Adj. Modo \\
\hline Ator Social & & & & \\
\hline
\end{tabular}

\begin{tabular}{|l|l|l|l|l|}
\hline & muitos & estão & $\begin{array}{l}\text { surpresos com os } \\
\text { movimentos } \\
\text { recentes }\end{array}$ & que \\
\hline Transitividade & Portador & $\begin{array}{l}\text { Proc. } \\
\text { Relacional }\end{array}$ & Atributo & \\
\hline
\end{tabular}




\begin{tabular}{|l|l|l|l|l|} 
& & atributivo & & \\
\hline Sistema de Modo & Sujeito & $\begin{array}{l}\text { Finito }+ \\
\text { Predicador }\end{array}$ & Complemento & Ator \\
\hline Ator Social & $\begin{array}{l}\text { Impessoalização- } \\
\text { Abstração }\end{array}$ & & $\begin{array}{l}\text { Impessoalização - } \\
\text { Assimilação - } \\
\text { Coletivização }\end{array}$ & \\
\hline
\end{tabular}

\begin{tabular}{|c|c|c|}
\hline & 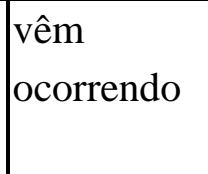 & $\begin{array}{l}\text { de segmentos da sociedade, em especial dos jovens, sob o mote } \\
\text { de redução dos preços das passagens de ônibus e outros } \\
\text { modais. }\end{array}$ \\
\hline Transitividade & $\begin{array}{l}\text { Proc. } \\
\text { Material }\end{array}$ & Circunstância \\
\hline Sistema de Modo & $\begin{array}{l}\text { Finito + } \\
\text { Predicador }\end{array}$ & Adj. Modo \\
\hline Ator Social & & Pessoalização - Determinação - Categorização \\
\hline
\end{tabular}

Vi um jovem, em São Paulo, dizer que a necessidade de redução dos preços das passagens foi o estopim para que esses movimentos fossem deflagrados esses movimentos e que retrata parte da insatisfação da sociedade brasileiros com o status quo, aqui e alhures, no mundo.

\begin{tabular}{|c|c|c|c|c|}
\hline & $\mathrm{Vi}$ & $\begin{array}{l}\text { um jovem, em } \\
\text { São Paulo, }\end{array}$ & dizer & \begin{tabular}{|l|} 
que a necessidade de redução \\
dos preços das passagens foi \\
o estopim para que esses \\
movimentos fossem \\
deflagrados esses \\
movimentos e que retrata \\
parte da insatisfação da \\
sociedade brasileiros com o \\
status quo, aqui e alhures, no
\end{tabular} \\
\hline
\end{tabular}




\begin{tabular}{|l|l|l|l|l|}
\hline & & & & mundo. \\
\hline Transitividade & $\begin{array}{l}\text { Proc. Mental } \\
\text { perceptivo }\end{array}$ & $\begin{array}{l}\text { Fenômeno + } \\
\text { Dizente }\end{array}$ & Proc. Verbal & Verbiagem \\
\hline Sistema de Modo & Finito + \\
Predicador & Sujeito & $\begin{array}{l}\text { Finito + } \\
\text { Predicador }\end{array}$ & Complemento \\
\hline Ator Social & & $\begin{array}{l}\text { Pessoalização - } \\
\text { Determinação - } \\
\text { Categorização }\end{array}$ & & $\begin{array}{l}\text { Impessoalização - } \\
\text { Assimilação - Coletivização }\end{array}$ \\
\hline
\end{tabular}

"Precisamos ouvir o povo".

\begin{tabular}{|l|l|l|l|}
\hline & Precisamos & ouvir & o povo \\
\hline Transitividade & & $\begin{array}{l}\text { Proc. Mental } \\
\text { perceptivo }\end{array}$ & Fenômeno \\
\hline Sistema de Modo & Modulação & $\begin{array}{l}\text { Finito + } \\
\text { Predicador }\end{array}$ & Complemento \\
\hline Ator Social & & & $\begin{array}{l}\text { Impessoalização - Assimilação - } \\
\text { Coletivização }\end{array}$ \\
\hline
\end{tabular}

As manifestações recém-ocorridas, excetuados os desmandos provocados por aqueles que querem se aproveitar politicamente desses momentos, que não concordo, e que não são objeto da maioria, que quer ver e sentir um novo caminho para o nosso País, são justas, democráticas e decorrem do saturamento da sociedade, porque estamos cegos e surdos.

\begin{tabular}{|l|l|l|l|}
\hline & $\begin{array}{l}\text { As manifestações } \\
\text { recém-ocorridas, }\end{array}$ & $\begin{array}{l}\text { excetuados os desmandos } \\
\text { provocados por aqueles } \\
\text { que querem se aproveitar } \\
\text { politicamente desses }\end{array}$ & $\begin{array}{l}\text { que não concordo, e que não são } \\
\text { objeto da maioria que quer ver e } \\
\text { sentir um novo caminho para o } \\
\text { nosso País, }\end{array}$ \\
\hline
\end{tabular}




\begin{tabular}{|c|c|c|c|}
\hline & & momentos, & \\
\hline \begin{tabular}{|l|} 
Transitividade \\
\end{tabular} & Portador & & \\
\hline $\begin{array}{l}\text { Sistema de } \\
\text { Modo }\end{array}$ & Sujeito & Adj. Modo & Adj. Comentário \\
\hline Ator Social & $\begin{array}{l}\text { Impessoalização - } \\
\text { Assimilação - } \\
\text { Coletivização }\end{array}$ & $\begin{array}{l}\text { Pessoalização - } \\
\text { Determinação - } \\
\text { Categorização }\end{array}$ & \\
\hline
\end{tabular}

\begin{tabular}{|c|c|c|c|c|c|}
\hline & são & $\begin{array}{l}\text { justas, } \\
\text { democráticas e }\end{array}$ & decorrem & $\begin{array}{l}\text { do saturamento da } \\
\text { sociedade, }\end{array}$ & porque \\
\hline Transitividade & $\begin{array}{l}\text { Proc. } \\
\text { Relacional }\end{array}$ & Atributo & \begin{tabular}{|l} 
Proc. \\
Material
\end{tabular} & Circunstância & Conjunção \\
\hline Sistema de Modo & $\begin{array}{l}\text { Finito }+ \\
\text { Predicador }\end{array}$ & Complemento & $\begin{array}{l}\text { Finito + } \\
\text { Predicador }\end{array}$ & Complemento & Conjunção \\
\hline Ator Social & & & & $\begin{array}{l}\text { Impessoalização- } \\
\text { Assimilação- } \\
\text { Coletivização }\end{array}$ & \\
\hline
\end{tabular}

\begin{tabular}{|c|c|c|}
\hline & estamos & cegos e surdos. \\
\hline Transitividade & Proc. Relacional & Atributo \\
\hline Sistema de Modo & $\begin{array}{l}\text { Finito }+ \\
\text { Predicador }\end{array}$ & Complemento \\
\hline Ator Social & $\begin{array}{l}\text { Pessoalização - } \\
\text { Determinação - } \\
\text { Diferenciação }\end{array}$ & \\
\hline
\end{tabular}


O SR. EDUARDO SCIARRA (PSD-PR. Como Líder)

Quero agora também me manifestar a respeito disso que tem surpreendido a toda a sociedade brasileira, essa movimentação das ruas que de forma difusa, ou de forma não identificada, essa insatisfação que foi manifesta em todas essas mobilizações pelo Brasil afora, não só em 11 Capitais, mas em mais de 40 Municípios em todo o País.

\begin{tabular}{|l|l|l|l|l|}
\hline & Quero & agora também & me manifestar & $\begin{array}{l}\text { a respeito disso que tem } \\
\text { surpreendido a toda a sociedade } \\
\text { brasileira, essa movimentação } \\
\text { das ruas que de forma difusa, ou } \\
\text { de forma não identificada, essa } \\
\text { insatisfação que foi manifesta } \\
\text { em todas essas mobilizações } \\
\text { pelo Brasil... }\end{array}$ \\
\hline Transitividade & $\begin{array}{l}\text { Proc. Mental } \\
\text { desiderativo }\end{array}$ & Circunstância & Proc. Verbal & Circunstância \\
\hline Sistema de Modo & $\begin{array}{l}\text { Finito }+ \\
\text { Predicador }\end{array}$ & Adj. Modo & $\begin{array}{l}\text { Finito }+ \\
\text { Predicador }\end{array}$ & Adj. Modo \\
\hline Ator Social & & & Impessoalização - abstração \\
\hline
\end{tabular}

E ele foi para a campanha procurando exatamente interpretar isto que a sociedade está manifestando neste momento: uma insatisfação generalizada com relação aos rumos não necessariamente da classe política, mas do Poder constituído; insatisfação, enfim, com o rumo que muitas coisas têm tomado em nosso País.

\begin{tabular}{|l|l|l|l|l|}
\hline & a sociedade & está & neste \\
manifestando & momento: & $\begin{array}{l}\text { uma insatisfação } \\
\text { generalizada com relação } \\
\text { aos rumos não } \\
\text { necessariamente da classe } \\
\text { política, mas do Poder }\end{array}$ \\
\hline
\end{tabular}




\begin{tabular}{|c|c|c|c|c|}
\hline & & & & $\begin{array}{l}\text { constituído; insatisfação, } \\
\text { enfim, com o rumo que } \\
\text { muitas coisas têm tomado } \\
\text { em nosso País. }\end{array}$ \\
\hline Transitividade & Dizente & Proc. Verbal & Circunstância & Verbiagem \\
\hline \begin{tabular}{|l} 
Sistema de \\
Modo
\end{tabular} & Sujeito & $\begin{array}{l}\text { Finito }+ \\
\text { Predicador }\end{array}$ & Adj. Modo & Complemento \\
\hline Ator Social & $\begin{array}{l}\text { Inclusão - Ativação } \\
\text { - Impessoalização - } \\
\text { Assimilação - } \\
\text { Coletivização }\end{array}$ & & & $\begin{array}{l}\text { Pessoalização - } \\
\text { determinação - } \\
\text { categorização - } \\
\text { funcionalização/ } \\
\text { Impessoalização - abstração }\end{array}$ \\
\hline
\end{tabular}

Mas, com toda a certeza, já antecipadamente dava para se dizer que aquela era uma manifestação silenciosa da população com relação a rumos que não estavam sendo entendidos como corretos pela população.

\begin{tabular}{|c|c|c|c|c|}
\hline & $\begin{array}{l}\text { Mas, com } \\
\text { toda a } \\
\text { certeza, }\end{array}$ & já antecipadamente & $\begin{array}{l}\text { dava para se } \\
\text { dizer que }\end{array}$ & $\begin{array}{l}\text { aquela era uma manifestação } \\
\text { silenciosa da população com } \\
\text { relação a rumos que não } \\
\text { estavam sendo entendidos } \\
\text { como corretos pela população. }\end{array}$ \\
\hline Transitividade & & & $\begin{array}{l}\text { Processo } \\
\text { Verbal }\end{array}$ & Verbiagem \\
\hline Sistema de Modo & Modalização & Adj. de Comentário & $\begin{array}{l}\text { Finito }+ \\
\text { Predicador }\end{array}$ & Complemento \\
\hline Ator Social & & & & $\begin{array}{l}\text { Pessoalização - Determinação } \\
\text { - Categorização - Avaliação }\end{array}$ \\
\hline
\end{tabular}

\begin{tabular}{|l|l|l|l|}
\hline & aquela & era & uma manifestação silenciosa da população com \\
\hline
\end{tabular}




\begin{tabular}{|l|l|l|l|}
\hline & & $\begin{array}{l}\text { relação a rumos que não estavam sendo } \\
\text { entendidos como corretos pela população. }\end{array}$ \\
\hline Transitividade & Portador & $\begin{array}{l}\text { Processo } \\
\text { relacional }\end{array}$ & Atributo \\
\hline Sistema de Modo & Sujeito & $\begin{array}{l}\text { Finito + } \\
\text { Predicador }\end{array}$ & Complemento \\
\hline Ator Social & & & $\begin{array}{l}\text { Pessoalização - Determinação - Categorização } \\
\text { - Avaliação }\end{array}$ \\
\hline
\end{tabular}

Essa reflexão, com toda a certeza, não pode ser fruto do calor do momento.

\begin{tabular}{|l|l|l|l|l|l|}
\hline & Essa reflexão, & $\begin{array}{l}\text { com toda a } \\
\text { certeza, }\end{array}$ & não pode & ser & $\begin{array}{l}\text { fruto do calor do } \\
\text { momento. }\end{array}$ \\
\hline Transitividade & Portador & & Relacional & Atributo \\
\hline $\begin{array}{l}\text { Sistema de } \\
\text { Modo }\end{array}$ & Sujeito & Modalização & $\begin{array}{l}\text { Polaridade + } \\
\text { modulação }\end{array}$ & $\begin{array}{l}\text { Finito + } \\
\text { Predicador }\end{array}$ & Complemento \\
\hline Ator Social & $\begin{array}{l}\text { Impessoalização - } \\
\text { abstração }\end{array}$ & & & & \\
\hline
\end{tabular}

É uma reflexão que tem de ser estudada, tem de ser analisada, e, essas ações para responder à sociedade têm de ser praticadas com toda a transparência, porque isso, sem dúvida nenhuma, é o que a sociedade tem nos cobrado.

\begin{tabular}{|l|l|l|l|l|}
\hline & É & $\begin{array}{l}\text { uma reflexão } \\
\text { que }\end{array}$ & tem de & ser estudada, \\
\hline Transitividade & $\begin{array}{l}\text { Proc. } \\
\text { Relacional }\end{array}$ & Atributo & & Proc. Mental cognitivo \\
\hline
\end{tabular}




\begin{tabular}{|l|l|l|l|l|} 
Sistema de Modo & & $\begin{array}{l}\text { Modulação } \\
\text { obrigação }\end{array}$ & Finito +Predicador \\
\hline Ator Social & & & & \\
\hline
\end{tabular}

\begin{tabular}{|c|c|c|c|c|}
\hline & tem de & ser analisada, & $\begin{array}{l}\text { e, essas ações para } \\
\text { responder à } \\
\text { sociedade }\end{array}$ & têm de \\
\hline Transitividade & & $\begin{array}{l}\text { Proc. Mental } \\
\text { cognitivo }\end{array}$ & Meta & \\
\hline Sistema de Modo & $\begin{array}{l}\text { Modulação } \\
\text { obrigação }\end{array}$ & \begin{tabular}{|l} 
Finito \\
+ Predicador
\end{tabular} & Sujeito & Modulação obrigação \\
\hline Ator Social & & & $\begin{array}{l}\text { Impessoalização- } \\
\text { Assimilação- } \\
\text { Coletivização }\end{array}$ & \\
\hline
\end{tabular}

\begin{tabular}{|l|l|l|l|l|l|l|}
\hline & $\begin{array}{l}\text { ser } \\
\text { praticadas }\end{array}$ & $\begin{array}{l}\text { com toda a } \\
\text { transparência }\end{array}$ & porque isso, & $\begin{array}{l}\text { sem dúvida } \\
\text { nenhuma, }\end{array}$ & é & $\begin{array}{l}\text { o que a sociedade } \\
\text { tem nos cobrado. }\end{array}$ \\
\hline Transitividade & $\begin{array}{l}\text { Proc. } \\
\text { Material }\end{array}$ & Circunstância & Identificador & & $\begin{array}{l}\text { Proc. } \\
\text { Relacional }\end{array}$ & Identificado \\
\hline $\begin{array}{l}\text { Sistema de } \\
\text { Modo }\end{array}$ & $\begin{array}{l}\text { Finito } \\
+ \text { Predicador }\end{array}$ & Adj. Modo & Sujeito & Modalização & $\begin{array}{l}\text { Finito + } \\
\text { Predicador }\end{array}$ & Complemento \\
\hline Ator Social & & & & & & $\begin{array}{l}\text { Impessoalização- } \\
\text { Assimilação- } \\
\text { Coletivização }\end{array}$ \\
\hline
\end{tabular}

Eu quero deixar aqui esta constatação e dizer que, com toda a certeza, essa mobilização das ruas deve ser entendida como uma manifestação de insatisfação. 


\begin{tabular}{|l|l|l|l|l|}
\hline & Eu & quero & deixar & aqui esta constatação e \\
\hline Transitividade & Experienciador & $\begin{array}{l}\text { Proc. Mental } \\
\text { desiderativo }\end{array}$ & Fenômeno & \\
\hline Sistema de Modo & Sujeito & Finito & Predicador & Complemento \\
\hline Ator Social & & & & \\
\hline
\end{tabular}

\begin{tabular}{|c|c|c|c|}
\hline & dizer que, & $\begin{array}{l}\text { com toda a } \\
\text { certeza, }\end{array}$ & $\begin{array}{l}\text { essa mobilização das ruas deve ser entendida } \\
\text { como uma manifestação de insatisfação. }\end{array}$ \\
\hline Transitividade & Proc. Verbal & & Verbiagem \\
\hline Sistema de Modo & $\begin{array}{l}\text { Finito }+ \\
\text { Predicador }\end{array}$ & Modalização & Complemento + Modulação obrigação \\
\hline Ator Social & & & Impessoalização - objetivação - espacialização \\
\hline
\end{tabular}

\section{O SR. EURICO JÚNIOR (PV-RJ.)}

Se durante as manifestações que aconteceram ontem por todo o Brasil o Dr. Ulysses, aí estivesse, diria que temos de ouvir o clamor das ruas.

\begin{tabular}{|l|l|l|l|l|l|}
\hline & $\begin{array}{l}\text { Se durante as } \\
\text { manifestações que } \\
\text { aconteceram } \\
\text { ontem por todo o } \\
\text { Brasil }\end{array}$ & o Dr. Ulysses & aí estivesse & diria & que temos de ouvir \\
o clamor das ruas.
\end{tabular}




\begin{tabular}{|l|l|l|l|l|} 
Ator social & $\begin{array}{l}\text { Impessoalização }- \\
\text { Assimilação - } \\
\text { Coletivização }\end{array}$ & $\begin{array}{l}\text { Nomeação - } \\
\text { Formalização }\end{array}$
\end{tabular}$|\quad| \begin{aligned} & \text { Impessoalização - } \\
& \text { objetivação - } \\
& \text { espacialização }\end{aligned}$

Queria também parabenizar os manifestantes que se comportaram de forma ...

\begin{tabular}{|l|l|l|l|l|}
\hline & (eu) & Queria & $\begin{array}{l}\text { também } \\
\text { parabenizar }\end{array}$ & $\begin{array}{l}\text { os manifestantes que se } \\
\text { comportaram de forma }\end{array}$ \\
\hline Transitividade & Experienciador & Proc. Mental & Proc. Verbal & Beneficiário \\
\hline $\begin{array}{l}\text { Sistema de } \\
\text { Modo }\end{array}$ & Sujeito & Finito & Predicador & Resíduo \\
\hline Ator social & & & & $\begin{array}{l}\text { Pessoalização - } \\
\text { DeterminaçãoCategorização }\end{array}$ \\
\hline
\end{tabular}

A PM, ontem, deu uma aula de democracia, junto com os manifestantes.

\begin{tabular}{|l|l|l|l|l|}
\hline & A PM & ontem, & deu & $\begin{array}{l}\text { lma aula de } \\
\text { democracia, junto } \\
\text { com os } \\
\text { manifestantes }\end{array}$ \\
\hline Transitividade & Ator & Adj. tempo & $\begin{array}{l}\text { Proc. Material } \\
\text { Criativo }\end{array}$ & Meta \\
\hline Sistema de & Sujeito & Adj. tempo & Finito + \\
Predicador & $\begin{array}{l}\text { Complemento } \\
\text { Determinação - } \\
\text { Categorização - } \\
\text { Funcionalização }\end{array}$ & & $\begin{array}{l}\text { Pessoalização - } \\
\text { Determinação - } \\
\text { Categorização }\end{array}$ \\
\hline
\end{tabular}


Queria registrar isso, que é muito importante. E parabenizar a atitude não só do Vaccarezza, do Guimarães e também do nosso Vice-Presidente Andre Vargas, que soube conduzir muito bem o movimento ontem.

\begin{tabular}{|l|l|l|l|l|}
\hline & (eu) & queria & parabenizar & $\begin{array}{l}\text { a atitude não só do Vaccarezza, do } \\
\text { Guimarães e também do nosso } \\
\text { Vice-Presidente Andre Vargas, }\end{array}$ \\
\hline Transitividade & dizente & & Proc. Verbal & Beneficiário \\
\hline Sistema de & Sujeito & Finito & Predicador & Resíduo \\
\hline Ator social & & & & $\begin{array}{l}\text { Pessoalização - Nomeação - } \\
\text { Semiformalização e Formalização }\end{array}$ \\
\hline
\end{tabular}

\section{O SR. NILSON LEITÃO (PSDB-MT. Como Líder.)}

Eu também ouvi da deputada, Líder do Pc do B, dizendo que foi a Polícia de São Paulo que assustou a população e que, graças a isso, cresceu esse movimento nas ruas.

\begin{tabular}{|l|l|l|l|l|}
\hline & Eu & também & ouvi & $\begin{array}{l}\text { da deputada, Líder } \\
\text { do Pc do B, }\end{array}$ \\
\hline Transitividade & Experienciador & & $\begin{array}{l}\text { Proc. Mental } \\
\text { perceptivo }\end{array}$ & Fenômeno/ Dizente \\
\hline $\begin{array}{l}\text { Sistema de } \\
\text { Modo }\end{array}$ & Sujeito & Adj. Modo & $\begin{array}{l}\text { Finito + } \\
\text { Predicador }\end{array}$ & Complemento \\
\hline Ator social & & & & $\begin{array}{l}\text { Pessoalização - } \\
\text { Determinação - } \\
\text { categorização - } \\
\text { funcionalização }\end{array}$ \\
\hline
\end{tabular}




\begin{tabular}{|c|c|c|}
\hline & dizendo & $\begin{array}{l}\text { que foi a Polícia de São Paulo que assustou a população e } \\
\text { que, graças a isso, cresceu esse movimento nas ruas. }\end{array}$ \\
\hline Transitividade & Proc. Verbal & Verbiagem \\
\hline \begin{tabular}{|l} 
Sistema de \\
Modo
\end{tabular} & $\begin{array}{l}\text { Finito }+ \\
\text { Predicador }\end{array}$ & Complemento \\
\hline Ator social & & $\begin{array}{l}\text { Impessoalização - objetivação - espacialização } \\
\text { Impessoalização - assimilação - coletivização } \\
\text { impessoalização - objetivação - espacialização }\end{array}$ \\
\hline
\end{tabular}

Não é susto o que a população está vivendo, é impaciência, indignação pela irresponsabilidade do Governo.

\begin{tabular}{|l|l|l|l|l|}
\hline & Não & é & susto & $\begin{array}{l}\text { o que a população está } \\
\text { vivendo, }\end{array}$ \\
\hline Transitividade & & $\begin{array}{l}\text { Proc. } \\
\text { Relacional }\end{array}$ & Atributo & Portador \\
\hline $\begin{array}{l}\text { Sistema de } \\
\text { Modo }\end{array}$ & Polaridade & $\begin{array}{l}\text { Finito }+ \\
\text { Predicador }\end{array}$ & Complemento & Sujeito \\
\hline Ator social & & & & $\begin{array}{l}\text { Impessoalização - } \\
\text { assimilação - } \\
\text { coletivização }\end{array}$ \\
\hline
\end{tabular}

\begin{tabular}{|l|l|l|}
\hline & é & $\begin{array}{l}\text { impaciência, indignação pela irresponsabilidade do } \\
\text { Governo. }\end{array}$ \\
\hline Transitividade & Proc. Relacional & Atributo \\
\hline
\end{tabular}




\begin{tabular}{|l|l|l|}
$\begin{array}{l}\text { Sistema de } \\
\text { Modo }\end{array}$ & $\begin{array}{l}\text { Finito }+ \\
\text { Predicador }\end{array}$ & Complemento \\
\hline Ator social & & Impessoalização - abstração \\
\hline
\end{tabular}

Quando vem uma Ministra a público dizer que o Brasil não tem projeto para fazer uma obra, eu me lembro daquele coitadinho que mora naquela cidade e que, para fazer sua casa meia-água, precisa aprovar na prefeitura o seu projeto, precisa de alvará, tem a fiscalização do CREA, tem a fiscalização de todo o mundo.

\begin{tabular}{|l|l|l|l|l|}
\hline & $\begin{array}{l}\text { Quando vem uma } \\
\text { Ministra a público } \\
\text { dizer que o Brasil } \\
\text { não tem projeto } \\
\text { para fazer uma } \\
\text { obra, }\end{array}$ & me lembro & $\begin{array}{l}\text { daquele coitadinho } \\
\text { que mora naquela } \\
\text { cidade... }\end{array}$ \\
\hline Transitividade & Circunstância & Experienciador & Proc. Mental & Fenômeno \\
\hline Sistema de & Adj. Modo & Sujeito & Finito + \\
Mredo & $\begin{array}{l}\text { Pessoadicador } \\
\text { determinação - } \\
\text { categorização - } \\
\text { funcionalização }\end{array}$ & & Complemento \\
\hline Ator social & & $\begin{array}{l}\text { Pessoalização - } \\
\text { determinação } \\
\text { categorização- } \\
\text { avaliação }\end{array}$ \\
\hline
\end{tabular}

Esse movimento da rua não tem proprietário.

\begin{tabular}{|l|l|l|l|l|}
\hline & $\begin{array}{l}\text { Esse movimento } \\
\text { da rua }\end{array}$ & não & tem & proprietário. \\
\hline Transitividade & Possuidor & & Proc. Relacional & Possuído \\
\hline Sistema de & Sujeito & Polaridade & Finito + & Complemento \\
\hline
\end{tabular}




\begin{tabular}{|l|l|l|l|l|} 
Modo & & & Predicador & \\
\hline Ator social & $\begin{array}{l}\text { Impessoalização - } \\
\text { objetivação - } \\
\text { espacialização }\end{array}$ & & & \\
\hline
\end{tabular}

É um movimento difuso e de várias camadas da sociedade.

\begin{tabular}{|l|l|l|}
\hline & É & $\begin{array}{l}\text { um movimento difuso e de várias camadas da } \\
\text { sociedade. }\end{array}$ \\
\hline Transitividade & $\begin{array}{l}\text { Processo } \\
\text { relacional } \\
\text { atributivo }\end{array}$ & Atributo \\
\hline $\begin{array}{l}\text { Sistema de } \\
\text { Modo }\end{array}$ & $\begin{array}{l}\text { Finito }+ \\
\text { Predicador }\end{array}$ & Complemento \\
\hline Ator social & & Impessoalização - Assimilação- coletivização \\
\hline
\end{tabular}

Mas muito mais do que da classe política, a sociedade se cansou do modelo que está aí.

\begin{tabular}{|l|l|l|l|l|}
\hline & $\begin{array}{l}\text { Mas muito mais do } \\
\text { que da classe } \\
\text { política, }\end{array}$ & a sociedade & se cansou & $\begin{array}{l}\text { do modelo que } \\
\text { está aí. }\end{array}$ \\
\hline Transitividade & Circunstância & Experienciador & Proc. Mental & Fenômeno \\
\hline $\begin{array}{l}\text { Sistema de } \\
\text { Modo }\end{array}$ & Adj. Modo & Sujeito & $\begin{array}{l}\text { Finito + } \\
\text { Predicador }\end{array}$ & Complemento \\
\hline Ator social & $\begin{array}{l}\text { Pessoalização - } \\
\text { Determinação - } \\
\text { Categorização - } \\
\text { Funcionalização }\end{array}$ & $\begin{array}{l}\text { Impessoalização- } \\
\text { Assimilação - } \\
\text { Coletivização }\end{array}$ & & \\
\hline
\end{tabular}


O Governo brasileiro não conseguiu ter rumo, não conseguiu ter um projeto onde efetivamente melhore a vida da população.

\begin{tabular}{|c|c|c|c|c|}
\hline & $\begin{array}{l}\text { O Governo } \\
\text { brasileiro }\end{array}$ & não & conseguiu & ter rumo, \\
\hline Transitividade & Ator & & Proc. Material & Meta \\
\hline $\begin{array}{l}\text { Sistema de } \\
\text { Modo }\end{array}$ & Sujeito & Polaridade & $\begin{array}{l}\text { Finito + } \\
\text { Predicador }\end{array}$ & Complemento \\
\hline Ator social & $\begin{array}{l}\text { Pessoalização - } \\
\text { Determinação - } \\
\text { Categorização - } \\
\text { Funcionalização }\end{array}$ & & & \\
\hline
\end{tabular}

\begin{tabular}{|l|l|l|l|}
\hline & não & conseguiu & $\begin{array}{l}\text { ter um projeto onde efetivamente } \\
\text { melhore a vida da população. }\end{array}$ \\
\hline Transitividade & & Proc. Material & Meta \\
\hline $\begin{array}{l}\text { Sistema de } \\
\text { Modo }\end{array}$ & Polaridade & $\begin{array}{l}\text { Finito }+ \\
\text { Predicador }\end{array}$ & Complemento \\
\hline Ator social & & & $\begin{array}{l}\text { Impessoalização - Assimilação - } \\
\text { Coletivização }\end{array}$ \\
\hline
\end{tabular}

Essa angústia da sociedade está sendo traduzida na rua agora por crianças, adolescentes, jovens, adultos e idosos.

\begin{tabular}{|l|l|l|l|l|}
\hline & $\begin{array}{l}\text { Essa angústia da } \\
\text { sociedade }\end{array}$ & $\begin{array}{l}\text { está sendo } \\
\text { traduzida }\end{array}$ & na rua agora & $\begin{array}{l}\text { por crianças, adolescentes, } \\
\text { jovens, adultos e idosos. }\end{array}$ \\
\hline Transitividade & Verbiagem & Proc. Verbal & Circunstância & Dizente \\
\hline
\end{tabular}




\begin{tabular}{|l|l|l|l|l|}
$\begin{array}{l}\text { Sistema de } \\
\text { Modo }\end{array}$ & Sujeito & $\begin{array}{l}\text { Finito }+ \\
\text { Predicador }\end{array}$ & Adj. Modo & Adj. Modo \\
\hline Ator social & $\begin{array}{l}\text { Impessoalização } \\
\text { - Assimilação - } \\
\text { Coletivização }\end{array}$ & & & $\begin{array}{l}\text { Pessoalização - } \\
\text { Determinação - } \\
\text { Categorização }\end{array}$ \\
\hline
\end{tabular}

O Governo brasileiro tem que ter autocrítica, humildade de entender que o Brasil chegou num momento em que não aguenta mais.

\begin{tabular}{|c|c|c|c|c|}
\hline & $\begin{array}{l}\text { O Governo } \\
\text { brasileiro }\end{array}$ & tem que & ter & $\begin{array}{l}\text { autocrítica, } \\
\text { humildade de } \\
\text { entender que }\end{array}$ \\
\hline Transitividade & Possuidor & & Proc. Relacional & Possuído \\
\hline $\begin{array}{l}\text { Sistema de } \\
\text { Modo }\end{array}$ & Sujeito & $\begin{array}{l}\text { Modulação } \\
\text { obrigação }\end{array}$ & $\begin{array}{l}\text { Finito + } \\
\text { Predicador }\end{array}$ & Complemento \\
\hline Ator social & $\begin{array}{l}\text { Pessoalização - } \\
\text { Determinação - } \\
\text { Categorização - } \\
\text { Funcionalização }\end{array}$ & & & \\
\hline
\end{tabular}

\begin{tabular}{|l|l|l|l|}
\hline & o Brasil & chegou & $\begin{array}{l}\text { num momento em que não aguenta } \\
\text { mais. }\end{array}$ \\
\hline Transitividade & Ator & Proc. Material & Meta \\
\hline Sistema de \\
Modo & Sujeito & $\begin{array}{l}\text { Finito + } \\
\text { Predicador }\end{array}$ & Complemento \\
\hline Ator social & $\begin{array}{l}\text { Impessoalização - } \\
\text { objetivação - } \\
\text { espacialização }\end{array}$ & & \\
\hline
\end{tabular}


A voz das ruas, essa voz do povo, que o PT tanto proclamou no passado, precisa ser defendida agora.

\begin{tabular}{|c|c|c|c|c|}
\hline & $\begin{array}{l}\text { A voz das ruas, } \\
\text { essa voz do povo, } \\
\text { que o PT tanto } \\
\text { proclamou no } \\
\text { passado, }\end{array}$ & precisa & ser defendida & agora. \\
\hline Transitividade & Beneficiário & & Proc. Material & Circunstância \\
\hline $\begin{array}{l}\text { Sistema de } \\
\text { Modo }\end{array}$ & Sujeito & $\begin{array}{l}\text { Modulação } \\
\text { obrigação }\end{array}$ & $\begin{array}{l}\text { Finito + } \\
\text { Predicador }\end{array}$ & Adj. Modo \\
\hline Ator social & $\begin{array}{l}\text { Impessoalização - } \\
\text { objetivação - } \\
\text { espacialização/ } \\
\text { Impessoalização - } \\
\text { Assimilação - } \\
\text { Coletivização/ } \\
\text { Pessoalização - } \\
\text { Determinação - } \\
\text { Diferenciação }\end{array}$ & & & \\
\hline
\end{tabular}

Ouçam esse povo e façam um governo decente.

\begin{tabular}{|l|l|l|l|l|l|}
\hline & Ouçam & esse povo & e & façam & $\begin{array}{l}\text { um governo } \\
\text { decente. }\end{array}$ \\
\hline Transitividade & $\begin{array}{l}\text { Proc. Mental } \\
\text { perceptivo }\end{array}$ & Fenômeno & & $\begin{array}{l}\text { Proc. } \\
\text { Material }\end{array}$ & Meta \\
\hline $\begin{array}{l}\text { Sistema de } \\
\text { Modo }\end{array}$ & $\begin{array}{l}\text { Finito + } \\
\text { Predicador }\end{array}$ & Complemento & Conjunção & $\begin{array}{l}\text { Finito + } \\
\text { Predicador }\end{array}$ & Complemento \\
\hline Ator social & & $\begin{array}{l}\text { Impessoalização - } \\
\text { Assimilação - } \\
\text { Coletivização }\end{array}$ & & & \\
\hline
\end{tabular}




\section{Íntegra dos discursos}

\section{[1]}

A SRA. AliCE PORTUGAL (PCdoB-BA. Como Líder.) - Sr. Presidente, Sras. e Srs. Deputados, aqueles que ainda nos ouvem nas galerias, serventuários da Justiça, - um abraço -,. especialmente os da Bahia, que aqui nos acompanham. Venho à tribuna desta Casa na medida que a PEC 190/07 está sem dúvida obstruída, a falta de quórum hoje prevalece neste plenário , mas para em nome da Liderança do PCdoB, que assumo com muita honra na ausência da titular, Manuela d'Ávila, em viagem oficial -, para dizer que o nosso partido está perfilado com a luta do povo em defesa dos seus direitos. Isso está na nossa matriz original. Esse partido, com mais de 90 anos de existência, o mais antigo em exercício político do Brasil. As manifestações que eclodiram País afora, inicialmente lastreadas na luta em defesa da não elevação dos preços das tarifas dos transportes, ganhou contornos difusos e espalhou-se pelo país. A verdade é que a atitude belicosa da Polícia paulista levou a um processo de solidariedade nacional e até internacional. A agressividade desmedida, a ação absolutamente intransigente daquele corpo militar, infelizmente, assustou o Brasil, e toda a revolta que havia em relação a essa situação da mobilidade urbana gerou essa expansão dessa batalha.No entanto, não é só isso que mobiliza os jovens e cidadãos e cidadãs nas ruas desse País. Há uma série de demandas que nós consideramos demandas justas e da democracia, demandas que devem ser escutadas por este Congresso Nacional, demandas que estão na nossa pauta.Por isso, o PCdoB escuta com muita clareza e participa das lutas populares. Este é o momento de entendermos que esse recado, é um recado que se bem assimilado, poderá fortalecer as vitórias sociais que já temos consolidado no Brasil.É preciso, portanto, saudar as manifestações espontâneas e autênticas, mas, ao mesmo tempo, repudiar a agressão policial desmedida e também atitudes infiltradas que visam constituir vandalismos, contaminando as manifestações e agredindo o processo democrático.O Brasil vive o período de democracia mais largo da sua história. Desde a República, é o período mais longo de democracia que vivemos. Temos acumulado grandes vitórias da expansão educacional, na infraestrutura brasileira, na garantia efetiva dos direitos para os que mais precisam, mas a juventude quer mais. E nós temos que dar mais. Nós temos que ampliar esse horizonte, nós temos que ter clareza. Em tempo, Presidente Biffi, parabenizo o Presidente em exercício da Casa, o Deputado Andre Vargas, que teve atitude serena, auspiciosa, de compreender a voz das ruas e não empreender uma repressão policial, como foi empreendida em outros lugares deste País.Portanto, é preciso compreender que as redes sociais integram internacionalmente, que neste momento, nós temos que, em torno desse movimento...

O SR. PRESIDENTE (Biffi) - Conclua, Deputada.

A SRA. ALICE PORTUGAL - Para finalizar, com a mesma tolerância que Vossa Exa. teve com os demais Líderes. Quero dizer que temos de constituir uma pauta adequada para abraçar este momento de mobilização das ruas, de onde nós saímos. Temos de abraçar a pauta dos $100 \%$ dos royalties; pedir ao Senado que vote os $10 \%$ do PIB para a educação; a garantia de um projeto, do Deputado Mendonça, que garante a desoneração do setor de 
transportes no Brasil. Nada disso foi possível hoje. Esperamos que seja possível na semana que vem.Mas não podemos admitir que vozes agourentas assaquem contra a democracia, queiram reduzir o valor das conquistas sociais e populares. Queremos sim fazer uma pauta consonante com a voz das ruas, mas, ao mesmo tempo, consagrando as vitórias adquiridas, porque elas não vieram de graça. Vieram com luta, que, inclusive, com a vida de muitos brasileiros. É a opinião do PCdoB, Sr. Presidente.Muito obrigada.

\section{[2]}

O SR. HENRIQUE FONTANA (PT-RS. Como Líder. Sem revisão do orador.) - Sr. Presidente Biffi, prezados colegas Parlamentares, primeiro digo que estou interinamente respondendo pela Liderança do Governo, já que o nosso Líder, Arlindo Chinaglia, está em missão oficial no exterior e eu, como Vice-Líder, assumo esta responsabilidade esta semana.

E a coincidência de assumi-la, Sr. Presidente, é que ontem nós tivemos um momento que merece, do meu ponto de vista, uma forte reflexão de todos nós, que representamos o povo brasileiro nesta Casa, os 513 Deputados e Deputadas ,com as mais diferentes visões que compõem esta Casa democrática. A minha primeira frase está em sintonia com a nossa Presidenta Dilma, que hoje pela manhã expressou o seu apoio, como não poderia deixar de ser, a manifestações que, de forma pacífica, na sua ampla maioria, reivindicam mudanças ainda maiores no nosso País. Talvez aqui, na função de Líder do Governo, não possa deixar de colocar uma crítica ao que ouvi do Líder da Minoria: aquele Parlamentar ou líder político que tentar transformar o importante recado que recebemos ontem nessa grande manifestação em combustível ou material para a luta entre partidos, para a luta entre Governo e Oposição, na minha avaliação, começará muito mal a interpretação que é profunda, que demanda reflexão complexa, que não deve ser respondida no automatismo da luta política tradicional entre Governo e Oposição, entre PT e PSDB ou em qualquer outro tipo de polarização.É evidente que a população que foi às ruas ontem, Presidente Biffi, especialmente os mais jovens, que foram maioria nas manifestações, querem uma saúde pública cada vez melhor, querem uma educação cada vez mais qualificada, querem transporte público mais barato e em condições cada vez mais qualificadas. E o nosso Governo assume isso como pauta que nos desafia permanentemente. Como disse a Presidenta Dilma hoje, no Palácio do Planalto, nós acolhemos integralmente essa pauta. Os nossos Ministros e a nossa bancada de sustentação queremos ouvir com muita atenção e buscar alternativas como, por exemplo, a diminuição dos impostos sobre o transporte coletivo, como por exemplo dedicar $100 \%$ dos royalties do petróleo para qualificar e ampliar a educação pública no País.Sr. Presidente, Sras. e Srs. Deputados, a pauta que está posta para este Parlamento é ouvir sim aquilo que a sociedade está colocando. E, do meu ponto de vista, devemos ter cuidado, porque, na minha avaliação, nós temos sido pautados com muita frequência por pautas de interesses coorporativos extremamente localizados, que são legítimos e são importantes, mas que não devem ser o centro da pauta do Parlamento brasileiro. Eu tenho uma posição pessoal contra a PEC 37. Mas o que eu venho a esta tribuna dizer é que, na minha opinião, a PEC 37 não deve ser a prioridade das prioridades 
no Parlamento brasileiro. Debater alternativas para um transporte coletivo melhor e mais barato seguramente entra cem vezes na frente do que a pauta da PEC $n^{\circ} 37$. Debater, por exemplo, alternativas para ampliar os investimentos na qualificação da educação está muito à frente da PEC 37.A PEC 37 está, marcada sim, essencialmente por uma pauta corporativa de uma instituição que merece todo nosso respeito, e da Polícia Federal, Polícia Civil e demais polícias que também merecem o nosso respeito. Agora, dizer que o tema central para o Brasil é debater quem deve ter a exclusividade da investigação não me parece um bom caminho para todos nós.Não posso deixar de dizer desta tribuna,e de pedir mais uma vez, nobres Líderes, prezadas Deputadas, prezados Deputados, nobre Presidente Biffi, nobre Presidente Henrique Eduardo Alves, eu entendo que o Parlamento não pode, não deve continuar adiando a votação da reforma política. O sistema político brasileiro dá sinais evidentes de falência, dá sinais evidentes de perda da capacidade de se sintonizar com a maior parte das demandas prioritárias da sociedade.O poder do dinheiro tem cada vez mais força para determinar as decisões do Parlamento. O poder das ideias, dos projetos, dos programas perde força na disputa pela prioridade na pauta deste Parlamento e também dos Executivos.O que ocorreu algumas semanas atrás? A maioria dos Líderes disse: "Não vamos votar a reforma política. A reforma política deve ficar na gaveta". Porque eu não digo que deva ser aprovado o relatório que apresentei. Eu defendo o financiamento público exclusivo de campanha; mas quem defende o financiamento privado pode subir à tribuna e defender que a continuidade da ampliação da interferência de empresas que financiam campanhas é o melhor para o Brasil.Agora, não votar, do meu ponto de vista, significa perder a sintonia com aquilo que é pauta nossa - pauta dos partidos, pauta do Parlamento -, que não é questão de Executivo, de Governo ou de Oposição. Ela foi retirada da pauta sem o direito de inclusive que a maior parte dos colegas que me encontram todas as semanas ali no cafezinho me perguntam: "Fontana, por que nós não vamos votar a reforma política?" E eu digo a eles: "Peçam o apoio de seus Líderes".O que nós queremos é trazer para dentro do Parlamento a votação, Deputado Zé Geraldo, Deputada Fátima Bezerra. Que apareçam as Maiorias e as Minorias, que respeitem as Maiorias, mas que melhore o sistema político brasileiro! Ou será que o elogio deste Parlamento é dizer que o sistema político atual é o melhor sistema político que o Brasil pode ter? E aí eu volto, para encerrar esta fala, dizendo - no último minuto que peço a V.Exa., que não me parece bom caminho o caminho escolhido por algumas falas, como foi a do Líder da Minoria, que quer partidarizar os recados, que são múltiplos e que vieram dos movimentos que ocorreram ontem.Nós devemos melhorar a política, nós devemos melhorar as políticas públicas, garantir liberdade para as pessoas se manifestarem. E, aliás, aqui quero ressaltar que a imensa maioria das pessoas que se manifestaram, se manifestaram de forma pacífica, politizada e de forma construtiva. E não pode jamais a minoria que optou pelo vandalismo ser a pauta central de movimentos que nos trazem recados extremamente importantes. Nosso Governo quer dialogar com essas reivindicações. Nosso Governo entende os movimentos que ocorreram ontem como um alerta para que nós continuemos aprofundando mudanças, reconhecendo erros, ampliando conquistas e, acima de tudo, sabendo que nunca um país está pronto e que nunca alguém pode se sentir o dono da verdade. Deixo um alerta desta tribuna: a solução para os problemas que estão sendo levantados por movimentos, como o que assistimos ontem, jamais deve ser a antipolítica; jamais deve ser a supressão da política, porque a política é o espaço que a democracia constrói para resolver os conflitos e 
para solucionar as legítimas demandas da população e da comunidade, de forma democrática, Sr. Presidente. (Muito bem!)

O SR. PRESIDENTE (Biffi) - Obrigado, Líder do Governo, Henrique Fontana.

[3]

O SR. JOSÉ GUIMARÃES (PT-CE. Como Líder. Sem revisão do orador.) - Sr. Presidente, Sras. e Srs. Parlamentares, eu quero, neste momento, expressar a posição da nossa bancada do PT neste momento que considero importante da vida nacional e, ao final, tecer alguns comentários sobre a pauta do Congresso, inclusive sobre a Proposta de Emenda à Constituição $n^{\circ}$ 37. Mas considero, Sr. Presidente, que a nossa bancada, reunida através de sua coordenação, expressa neste momento aqui uma opinião política, fruto do legado de 33 anos de vida e que provavelmente o Brasil não seria o Brasil de hoje sem o Partido dos Trabalhadores.

A bancada do PT na Câmara saúda as manifestações populares que têm ocorrido nas ruas de diferentes cidades brasileiras. Como lembrou a Presidenta Dilma Rousseff, hoje, lá no Palácio do Planalto: "O Brasil acordou nesta terça-feira mais forte com as manifestações realizadas em todo o País, comprovando a energia da nossa democracia, a força das vozes da rua e o civismo de nossa população". A bandeira por um país mais justo e melhor, levantada por milhares de jovens, coincide com o que o PT defende e tem motivado nossas lutas na condução do Brasil. As manifestações são legítimas e as reivindicações e os métodos para expressá-las fazem parte do sistema democrático brasileiro. Compete às instituições do Estado Democrático de Direito dialogar com esse sentimento. Os milhares de manifestantes deram um duro recado aos governantes de todas as instâncias e aos três Poderes da República; deram um recado, sim, ao Governador de São Paulo, Geraldo Alckmin; deram um recado, sim, aos Prefeitos de capitais. E deram um recado, sim, a nós, todos os Congressistas, nas manifestações de ontem aqui na Câmara Federal. Trata-se da expressão do desejo de influir nas decisões de todos os Governos, do Legislativo e do Judiciário.A elevação de 40 milhões de pessoas à classe media é um exemplo emblemático de como o Brasil mudou.Surgiu, consequentemente, uma nova agenda, demandando mais inclusão, mais distribuição de renda, acesso a mais e melhores empregos, a bens de serviços e melhorias na qualidade de vida, com base num modelo ambientalmente sustentável. Surgem, portanto, novos desafios para os governantes de todos os níveis. A bancada do PT e nosso Governo estão em plena sintonia com as reivindicações expressas nas ruas, pois elas são produto de uma sociedade em transformação e em busca de novas conquistas e que consolidem o Brasil como um dos países mais democráticos do nosso planeta. Avançamos e podemos avançar ainda mais. A agenda do desenvolvimento do Brasil, depois de décadas, foi finalmente desinterditada. A bancada do PT recorda que várias conquistas na área dos 
transportes públicos, por exemplo, aconteceram em governos petistas, como a implementação do bilhete único em São Paulo, em 2004, que proporcionou uma redução de custo de $30 \%$ para o usuário do sistema.O Governo Dilma acaba de editar a Medida Provisória $n^{\circ}$ 617, que zera as alíquotas da contribuição do PIS/PASEP e da COFINS incidentes sobre a receita decorrente da prestação de serviços regulares de transporte coletivo municipal rodoviário, metroviário e ferroviário de passageiros, o que permitirá reduzir o preço das passagens - e vou dizer de novo -, o que permitirá reduzir o preço das passagens.

Defendemos $100 \%$ dos royalties do petróleo para a educação e uma ampla reforma política, que amplie os canais de expressão e participação popular, incluindo financiamento público exclusivo das campanhas eleitorais.Na questão da saúde, é necessário avançar em termos de recursos e na eficiência, incluindo o enfrentamento aos grupos privados que buscam enfraquecer o modelo público vitorioso do SUS.A democracia representativa torna-se mais forte com a incorporação da mobilização popular, das vozes do povo e das manifestações expressadas por pessoas de diferentes orientações políticas e ideológicas. $\mathrm{O}$ uso de redes sociais nos debates políticos e na mobilização confere importância a um tema essencial de nossa pauta, que é a democratização dos meios de comunicação, e enfraquece o monopólio dos grupos midiáticos empresariais, que sempre estiveram interpretando os fatos de acordo com suas conveniências.O povo na rua é nossa história. Lá é o espaço que revigora nossa democracia e proporciona o avanço da participação direta do cidadão na política. Ouvir as vozes das ruas é dever de todos os poderes, para mudar práticas e aprofundar o processo de transformações em busca de uma sociedade moderna, justa, democrática e com igualdade de oportunidades para todos.Essa é a posição da nossa bancada sobre os episódios que tivemos a honra de ontem aqui. Digo "honra" porque nós somos herdeiros desse legado.Sr. Presidente, quero finalizar apresentando mais três questões importantes, além da posição da nossa bancada.Em primeiro lugar, dizer e elogiar aqui neste momento a condução dada pelo Presidente interino da Casa, Deputado Andre Vargas, a Polícia Militar do Distrito Federal. Ontem, aqui, nós passamos mais de 8 horas negociando, e não teve nenhuma tragédia. Não foi preciso usar a tropa de choque para reprimir os manifestantes, como aconteceu no Palácio dos Bandeirantes, em São Paulo, e como aconteceu na ALEGI no Rio de Janeiro. A manifestação aqui foi pacífica e democrática. E eu estava ao lado do Deputado Andre Vargas, do Deputado Mendonça Filho, do DEM, do Deputado Cândido Vaccarezza, e de outros Parlamentares que chegaram no momento daquele conflito. Hoje poderia estar nas páginas dos jornais: "O Congresso derrubado, o Congresso em cenas de guerra". Nós evitamos esse confronto, e quem evita isso é quem tem história vinculada à construção da democracia do Brasil. Portanto, quero elogiar o Governador Agnelo, que, com a sua Polícia, garantiu a preservação da ordem pública.Em terceiro lugar, Sr. Presidente, dentro do meu tempo, quero dizer que hoje a bancada do PT, na reunião dos Líderes, propôs um acordo para destravar a pauta política desta Casa. Nós propusemos, Deputada Fátima, os 
defensores da educação pública propusemos dois acordos, e a Oposição concordou que em primeiro lugar nós votássemos os royalties do petróleo e 100\% deles para a educação, porque aí sim se mostra compromisso com a educação pública. Não foi possível acordarem os Líderes. Propusemos votar o projeto do Deputado Mendonça Filho que desonerava o PIS/COFINS do sistema de transporte coletivo. Não deu acordo, e aqui estamos nós. O que é importante neste momento? Não é nós fazermos média com quem quer que seja; nós temos que constituir uma pauta que desinterdite o debate político aqui dentro. E que a Câmara se coloque, como se colocou ontem, no debate político nacional. É importante.Não acho conveniente, daqui para a próxima semana, nós votarmos determinadas matérias. O PT não quer tirar, por exemplo, o poder do Ministério Público de investigar. O PT não quer isso. Agora, o que o PT quer também é estabelecer regras, é estabelecer limites para que os direitos fundamentais da pessoa humana e o trânsito em julgado sejam elementos fundantes da democracia brasileira. Os exageros que acontecem pelo Brasil afora não podem transformar-se em norma, não podem transformar-se no arcabouço jurídico que dá sustentação às investigações do nosso País. Como disse o Presidente Henrique Alves, precisamos modelar essa matéria, não para fazer discurso aqui fácil, mas para entender que a democracia brasileira precisa de um Parlamento forte, de um Ministério Público forte, de um Poder Judiciário forte e de um Poder Executivo forte.É com esse entendimento, Sr. Presidente, que quero, em nome da minha bancada, da bancada do PT, afirmar: não tememos nada que está acontecendo. Não é um movimento contra a Presidenta Dilma. Eu poderia chegar aqui e dizer: "É um movimento que está contra o mensalão mineiro, é um movimento que está contra isso e aquilo." Esse movimento de indignação é retrato de uma geração que foi alçada à condição de classe média, até pelas políticas públicas do nosso Governo, que agora colocou na agenda outras demandas, e nós temos que ouvir das ruas isso.Nós do PT não nos sentimos intimidados com nenhuma manifestação. Ela é democrática, e nós somos herdeiros disso. E o movimento precisa dialogar com o Congresso Nacional, para se construir uma pauta nova, que dê vazão às manifestações, mas sem maniqueísmo, sem puxar para um lado e para o outro, porque aqueles mesmos que estavam ontem em Brasília são os mesmos de Fortaleza, são os mesmos de Belo Horizonte, são os mesmos do Palácio dos Bandeirantes, em São Paulo, são os mesmos do Rio de Janeiro. É a juventude do Brasil, que agora quer construir uma outra agenda. E esta Casa tem que construir uma outra agenda, para podermos dar vazão a essas manifestações ocorridas no Brasil afora.Nossa solidariedade aos manifestantes, sobretudo... O SR. MIRO TEIXEIRA - Sr. Presidente, o PDT pode mudar de orientação.Já acabou o orador?

O SR. PRESIDENTE (Biffi) - Ainda não.O SR. JOSÉ GUIMARÃES - Sr. Presidente, quero finalizar dizendo que isso é muito importante para nós. Portanto, nós da bancada construímos esse entendimento e vamos construir uma pauta que dê conta dos grandes 
temas nacionais, porque essa é a que vai mudar a imagem que a sociedade brasileira tem do Congresso Nacional.Muito obrigado, Sr. Presidente.

O SR. MÁRIO HERINGER (PDT-MG. Como Líder. Sem revisão do orador.) - Sr. Presidente, parece que o recado chegou ontem, mas o recado não terminou. Nós temos agora, em andamento, manifestação pelo Brasil todo. Lá em São Paulo, um grupo em torno de 50 mil pessoas já está em torno da Prefeitura da cidade, e o Prefeito da cidade já teve que se retirar, em função da pressão que sente. Senhoras e senhores, a sociedade está dizendo para nós que está cansada do jeito que a gente faz política, que está cansada de ser levada e empurrada com a barriga. Infelizmente, o que nós fazemos e o que temos feito não mais atende ao que essa sociedade quer.Nós temos hoje uma tecnologia onde as pessoas se falam, e nós aqui não estamos ouvindo essas pessoas. O nosso comportamento é só o de falar. O momento, Sr. Presidente, Srs. Deputados, é de ouvir essa sociedade, e uma maneira de ouvir essa sociedade é uma maneira constitucional.Nós temos que perguntar a essa sociedade, através do plebiscito, o que ela quer fazer, dentro dos temas que nós temos que discutir. Nós não podemos agora começar a criar uma pauta mínima que satisfaça essa sociedade, para a gente, ao final, saia daqui com o mesmo discurso: "Fizemos uma pauta positiva. Atenção, imprensa do Brasil: trabalhamos até às 5 horas da madrugada. Olha como nós somos bons! 'É desse jeito que nós queremos continuar sendo tratados? É desse jeito? As prerrogativas do Poder Legislativo foram abandonadas por esta Casa há algum tempo. Nós não nos damos o respeito! Está na hora de ouvir essa a sociedade e de dizer para essa sociedade que é ela que nos comanda. Não somos nós, os seus representantes, que vamos ditar o caminho a ser seguido.Infelizmente, senhoras e senhores, esse movimento chegou tarde. Já devia ter chegado há muito mais tempo. Nós estamos negligenciando um mandato que nos foi delegado, porque não estamos respeitando a sociedade, que nos colocou aqui. Aqui a gente vota, há algum tempo - e já tenho me cansado de repetir -, interesses corporativos, interesses econômicos. E cadê o fator previdenciário dos nossos idosos, aqueles que já trabalharam pelo Brasil? Cadê as 40 horas do trabalhador brasileiro? Onde estão? A gente não fala desse assunto. E a regulamentação da Emenda 29 da saúde? Esquecemos. Mas a sociedade não esquece. A passagem, os 20 centavos da passagem foram os 20 centavos mais benditos que aconteceram para a sociedade brasileira, porque trouxeram os brasileiros, e nós desta Casa estarrecidos e extasiados pelo sucesso de uma manifestação que já deveria ter ocorrido. Nós estamos aqui é para bater palmas para um Brasil que participa, para bater palma para um Brasil que reivindica. Nós nos desatualizamos. Nós não vivemos mais no tempo em que se esperava uma carta chegar. Aqui se faz em 2 milésimos de segundos no Japão se escuta. E nós estamos aqui tentando resolver o problema do Brasil ainda usando forno a lenha.O que está acontecendo com esta Casa? O que está acontecendo com as instituições? Nós estamos esquecendo das prerrogativas. Nós estamos esquecendo para que nós estamos aqui.Eu queria dizer aos senhores que, neste momento, o PDT tem uma série de reivindicações a fazer, tem uma série de medidas a serem discutidas, mas o PDT quer colocar a sua posição de parar. Não vamos tomar decisões açodadas e correndo. É parar e conversar com a sociedade, é ouvir a sociedade. Tomar a decisão de preparar uma pauta positiva eu já assisto há alguns anos 
aqui. Pauta positiva, ela só atende a emergência, acreditando que, depois daquela emergência, o problema vai se sanar. Vai acabar o problema porque fizemos uma pauta positiva.

Nós não vamos ter o respeito da sociedade. Nós não vamos ter o respeito de nós mesmos, desta Casa, não vamos ter o respeito do povo brasileiro se nós acharmos que isso é só uma lufada de liberdade. Isso é um grito! Isso é um berro! Isso vai continuar, está continuando hoje e vai aumentar! Esta Casa tem que deixar de ir a reboque e ser proativa. Muito obrigado, Sr. Presidente.

O SR. MENDONÇA FILHO (DEM-PE. Como Líder. Sem revisão do orador.) - Sr. Presidente, Sras. e Srs. Deputados, o Brasil ontem ouviu literalmente a chamada voz rouca das ruas. O Brasil parou, em grandes e importantes cidades, de forma democrática, plural onde a população teve oportunidade de se manifestar, indignada, por certo, e revoltada em grande medida por conta daquilo que é percebido no contato direto com o cidadão comum: o poder público anda literalmente divorciado da sociedade brasileira.Eu estava aqui, aqui cheguei às $18 \mathrm{~h} 30 \mathrm{~min}$ e acompanhei até $23 \mathrm{~h} 30 \mathrm{~min}$. Diga-se de passagem, o Sr. Presidente da Casa em exercício, o Deputado Andre Vargas, teve conduta irrepreensível, do ponto de vista do comportamento, na recepção à grande e importante manifestação de frente ao Congresso Nacional.Jovens, na sua grande maioria, protestando e dizendo: "Basta, o Brasil precisa mudar!" Os políticos, os Governos, todos que representam o setor público precisam ouvir a sociedade.É evidente que, diante desse quadro todo vivenciado nos últimos dias pela sociedade brasileira, não podemos restringir tão somente ao Congresso, ao Parlamento, todo o ônus dessa revolta, dessa insatisfação.Há de se ter claro as responsabilidades de quem também comanda o País, comanda a Nação. A Presidenta Dilma, o seu Governo, o PT e seus aliados há 10 anos no poder. A revolta foi expressa de forma bastante diversa: PEC 37; indignação por parte da sociedade com a possibilidade da ampliação da impunidade na realidade nacional; diferença enorme, gigante entre a realidade do mundo prometida pela Copa do Mundo, dos grandes estádios, do grande luxo, do grande volume de recursos investidos nos grandes do Brasil, e aquilo que foi prometido ao povo no chamado PAC da Mobilidade, Dilma prometeu 18 bilhões de reais de investimentos em transporte público na campanha política, e até hoje investiu apenas 1,3 bilhão de reais. É ridículo, minha gente!Quem vive o dia a dia do povo percebe claramente a distância entre a realidade da propaganda, entre a realidade do discurso e a realidade do povo. Mais do que isso: há quem diga que a agenda da conquista do passado, da estabilidade econômica e do crescimento da renda, já está consagrada e que o povo quer mais, o povo quer sempre mais, não só isso.É evidente que o povo quer sempre mais. Falta saúde. A saúde pública é de péssima qualidade. Os planos de saúde estão cada vez mais entupidos de demandas, e podendo oferecer um serviço de pior qualidade a cada dia que passa. A educação pública no Brasil também não avança, piora a cada dia que passa. Quanto ao transporte público, nem 
se fale, é uma piada nos grandes centros urbanos. O Governo pensa tão somente em políticas tópicas: financiamento para automóvel, financiamento para eletrodoméstico. Enquanto isso, o cidadão trabalhador acaba se perdendo no trânsito das grandes cidades do Brasil. Esta é a realidade de vida da nossa sociedade.E mais: a conquista do passado começa a ser perdida, porque a grande conquista do passado recente - e hoje celebramos, inclusive com a presença do Presidente Fernando Henrique, o Plano Real - é decorrente do fim da inflação. E a inflação hoje incomoda a população: $20 \%$ na cesta básica, atingindo a renda do trabalhador brasileiro. Há perda de renda na classe média, há perda de renda do trabalhador de baixa renda, há falta de investimento em transporte, há falta de investimento em saneamento básico.As obras dos aeroportos, no caso do PAC da Mobilidade, da Copa, estão todas atrasadas. As grandes obras prometidas para o Nordeste, que deveriam ter sido inauguradas em 2010, como a Refinaria Abreu e Lima, em Pernambuco, a transposição do Rio São Francisco, a Transnordestina, ainda estão empacadas, não saíram do lugar, não foram entregues à sociedade.É por tudo isso, minha gente, que o povo vai às ruas, por conta da PEC 37, do descaso daqueles que representam o Governo, de parcela do Congresso Nacional que há esta revolta popularA gente tem que ouvir a voz do povo e oferecer a resposta correta à sociedade, fazendo com que se mude a agenda. A agenda tem que ser agenda em favor da maioria, e não só naquela ação tópica, não só naquela ação pontual, não só naquela ação eleitoreira, não só naquela ação que tem levado cada vez mais o Brasil a diminuir o ritmo de crescimento, como está acontecendo este ano. Se previa 4\%, e vamos ter quiçá, de $2,5 \%$, com a inflação cada vez maior afetando a qualidade de vida da nossa população.É lamentável, mas é a pura realidade de vida da maioria esmagadora da população brasileira.

O SR. MARCELO CASTRO (PMDB-PI. Como Líder. Sem revisão do orador.) - Sr. Presidente, Sras. e Srs. Deputados, todos os partidos, hoje à tarde, se manifestaram sobre esse movimento que tomou conta do Brasil. Quero deixar aqui a opinião, a percepção que o PMDB tem dessa realidade que nós estamos vivendo hoje em nosso País.Primeiro, isso é um movimento nitidamente da classe média brasileira. Não são as minorias, não são os negros, não são os pobres, não são as mulheres, não são os ricos, é a classe média que está manifestando de uma maneira generalizada, de uma maneira difusa a sua insatisfação. Insatisfação contra quem? Naturalmente, contra o Governo. Qual Governo? Na nossa percepção, contra todos os Governos - contra o Governo Federal, contra os Governos Estaduais, contra os Governos Municipais, contra o Governo do PT, contra o Governo do PMDB, contra o Governo do PSDB, contra o Governo do PSB. Ou seja, é um movimento de revolta nacional contra o que está estabelecido, contra o status quo, contra o establishment. Essa é que é a realidade. E que nós políticos temos que ter a frieza de ânimo, temos que ter a clareza de ideias de saber captar essa mensagem.A Presidente Dilma foi vaiada aqui no Mané Garrincha. A Oposição tira uma onda com isso: "A Presidente Dilma foi vaiada". Qual é o político que já não foi vaiado? Não existe. Nelson Rodrigues, uma das nossas grandes referências literárias, dizia que o brasileiro é irreverente: vaia tudo, 
vaia até minuto de silêncio. Então, o nosso Lula foi vaiado, a Dilma foi vaiada, todos foram vaiados. E todos serão vaiados um dia. Isso é da natureza da política. Isso não acrescenta nem tira nada, na nossa concepção, do Governo da Presidente Dilma.Agora, Sr. Presidente, o que é esse movimento de classe média? Por que surgiu isso? Somos ingênuos de achar que isso surgiu por causa do aumento de 20 centavos no preço da passagem? De maneira nenhuma. Isso aí foi a gota d'água, foi o estopim que disparou um gatilho de uma insatisfação generalizada.O que é que vocalizam as pessoas que são entrevistadas e nas redes sociais? Vocalizam, principalmente, a questão dos estádios. Mas isso é uma coisa que a gente comentava todos os dias.A pessoa vai atrás de saúde, é um deus nos acuda! Educação, segurança. Todo dia, toda hora, há um vizinho, um amigo que é assaltado. Vai atrás da mobilidade urbana. Transporte de cargas: ineficiente. Entra num estádio, o Maracanã, 1,5 bilhão de reais. As pessoas tomam um choque. Acham que o dinheiro público não está sendo bem aplicado. Nós temos que ter esse entendimento. Juntamente com isso vem a ideia da corrupção também. Então, é um movimento contra o aumento da passagem, contra os estádios da Copa, contra a corrupção.Eu vi na rede social a pessoa dizendo: "O brasileiro vaiou a Dilma porque é sem educação". Aí o camarada completa: "É sem educação,é sem saúde, e, agora, sem paciência". Ora, gente, isso nós não podemos deixar isso passar sem tirar uma lição. O que esse movimento mais prega? Falta de saúde, falta de educação, falta de transporte de qualidade, falta de segurança. Está nas redes sociais: "Nós queremos saúde e segurança no Brasil. Queremos educação no Brasil padrão FIFA". Ou seja, os estádios do Brasil viraram uma referência para essas pessoas que estão indignadas e demostrando a sua indignação.Agora, qual a grande reflexão que nós, do Parlamento, precisamos fazer? O quanto esta Casa está dissociada da realidade brasileira. Quem de nós, verdadeiramente, supunha, pensava, acreditava que pudesse haver no Brasil tamanha insatisfação? Foi preciso haver esses movimentos populares para que nós caíssemos na real e víssemos o quanto a sociedade brasileira, especialmente a classe média brasileira, está insatisfeita. E nós não podemos ficar inertes. Temos que tomar as nossas providências.Existe, sim, Sr. Presidente, Sras. e Srs. Deputados, uma dissociação, um divórcio entre a classe política e a sociedade brasileira; entre nós, representantes, e os representados.E aqui eu quero fazer minhas as palavras do Líder do Governo em exercício hoje, o Deputado Henrique Fontana. Nós cometemos, a meu julgamento, um erro grave, este ano, neste Parlamento. O sistema eleitoral brasileiro, afirmo com a máxima convicção, é o pior sistema eleitoral do mundo. Um sistema caríssimo, com eleições caríssimas, com um excesso de influência do poder econômico, com promiscuidade entre os candidatos e os financiadores de campanha.Nós fizemos um trabalho durante 2 anos, e, infelizmente, os Líderes desta Casa se recusaram a colocar um projeto de reforma política em votação.Pelo amor de Deus! Gente, democracia é a expressão da vontade da maioria, sem massacrar, sem diminuir, respeitando as minorias.O Deputado Henrique Fontana, Relator da matéria, apresentou um projeto. Eu discordava de muitas partes do projeto do Deputado Henrique Fontana. O que eu fiz? Preparei 12 emendas ao seu projeto, contradizendo as suas posições, para nós discutirmos em plenário, votarmos, e a Maioria expressar sua vontade. Era isso que nós precisávamos ter feito. Nossos Líderes se reuniram e decidiram negar a esta Casa o direito de decidir sobre uma reforma política.Aqui, Sr. Presidente, srs. Deputados, é meaculpa que devemos fazer. Tivemos a oportunidade de avançar, de aproximar o Parlamento do povo brasileiro, de fazer partidos programáticos que pudessem representar correntes de 
pensamento nacional, e não o fizemos. Optamos pela inércia, pelo imobilismo, por esse sistema eleitoral que distancia cada vez mais, que divorcia o seu representante dos representados brasileiros.Muito obrigado. Tenho dito!

\section{[7]}

O SR. ARNALDO JORDY (PPS-PA. Como Líder. Sem revisão do orador.) - Sr. Presidente, Sras. e Srs. Deputados e todos os que assistem a esta sessão, primeiro eu queria, Deputado Andre Vargas, parabenizar V.Exa. e, na sua pessoa, os demais Deputados que estavam aqui ontem, pelo equilíbrio, pela serenidade de negociar e dialogar, tanto com a Polícia Militar quanto com a comissão de manifestantes que estavam ontem aqui, tomaram esta Casa, e, evidentemente, evitando prejuízos e situações de conflito maiores. Em segundo, eu queria festejar essa onda democrática, essa manifestação cívica da sociedade brasileira, da juventude brasileira, associando-me, na análise daqueles que fazem o diagnóstico de que não houve um comando único. Essa é uma manifestação plural de lideranças, de atores sociais, políticos, inclusive, mas principalmente de atores sociais. E cada um manifestou-se ontem, por este Brasil afora, com a sua agenda reprimida de desejos, de necessidades, principalmente sinalizando para as instituições, para os Governos, para as elites deste País, que o sistema precisa mudar, que há um grau de insatisfação reprimida. Como já foi dito aqui, há um pacto social e político engendrado ou entendido pelas lideranças e outro, de natureza diversa na sociedade civil aí fora, e nós precisamos estar atentos a isso. Eu lamento a falta de reflexão diante dessas manifestações. Hoje eu vi 40 mil pessoas, em São Paulo, manifestarem-se em praça pública, o que inclusive não estava previsto para o dia de hoje. Inclusive o Prefeito sendo retirado da cidade de São Paulo, por conta da população que tomou conta das ruas.Acho que essas manifestações tiveram duas provocações iniciais. Uma foram as obras da Copa. E, aqui para nós, as obras da Copa, para as quais tinham sido previstos no início investimentos de $\mathrm{R} \$ 2,5$ bilhões, hoje já somam R\$ 8,7 bilhões. Não há explicação, no nosso entendimento, para um crescimento deste porte: de $\mathrm{R} \$ 2,5$ bilhões para $\mathrm{R} \$ 8,7$ bilhões. Alguma coisa muito estranha está acontecendo. Não foi falta de alerta. E a população, com razão, começa a questionar essas obras faraônicas, enquanto a agenda básica da sociedade está sobrestada.( $O$ microfone é desligado.)

O SR. ARNALDO JORDY - Vou concluir, Sr. Presidente. A outra questão são os transportes. Evidentemente, não é por $\mathrm{R} \$ 0,20$, nem por $\mathrm{R} \$ 0,10$, mas o nosso sistema de transporte está falido. Há um projeto aqui sobre isso, e eu acho que além da Comissão Geral, que foi sugerida na reunião de Líderes para quarta-feira, para ouvirmos os reclamos da sociedade, precisamos também estabelecer uma agenda mínima. Essa agenda mínima já reúne muitos pontos de consenso aqui. Nós temos a jornada de 40 horas; nós temos o fim do fator previdenciário; nós temos o fim desta excrecência que é o voto secreto, que impede que o cidadão controle o seu representante, diante da possibilidade inclusive de julgar os seus atos nesta democracia representativa que já dá sinais de falência, neste sistema político brasileiro que nós precisamos rever imediatamente; nós temos a questão da defensoria pública, que já é de certa forma objeto de consenso; a questão dos royalties, seja na 
definição dos $50 \%$ para a saúde, $50 \%$ para a educação, que vários aqui advogam, seja para outras destinações; mas essas são coisas que das quais imediatamente precisamos estabelecer essa agenda mínima, além da Comissão Geral que foi proposta aqui pelo Deputado Beto Albuquerque e acolhida pelos Líderes na reunião de Lideranças.Portanto, eu acho que este é um novo tempo e que, apesar dos perigos, da força mais bruta, da noite escura, nós haveremos de sobreviver, diante desses desafios que estão sendo colocados, como diria o poeta Ivan Lins.Parabéns à sociedade brasileira, e parabéns a esta Casa, que está refletindo sobre essas demandas. Na quinta-feira haverá outra mobilização geral neste País. Acho que esta Casa, esta Câmara dos Deputados precisa imediatamente associar-se ao povo brasileiro nessas reclamações lícitas que ele está levando às ruas. Muito obrigado, Sr. Presidente.

O SR. CARLOS SAMPAIO (PSDB-SP. Como Líder. Sem revisão do orador.) - Sr. Presidente, colegas Deputados e Deputadas, venho a esta tribuna evidentemente porque não poderia me calar diante dos movimentos que tomam conta de inúmeros Estados e que de certa forma dizem respeito também aos problemas de ordem nacional.Ontem, conversando com o meu filho - confesso a V.Exas. -, indagou-me ele quais as razões que poderiam estar por trás desses movimentos, e afirmou-me ele mesmo que muitas eram as razões. Eu creio que ele tem razão. Este é um movimento em que pese difuso, este é um movimento em que pese disperso, este é um movimento sem dúvida de indignação. Indignação com o quê? Indignação com a corrupção? Sem dúvida. Indignação com o mensalão? Sem dúvida. Indignação com uma educação e uma saúde precárias? Sem dúvida. Indignação generalizada, dispersa, difusa? Sem dúvida.Ocorre, Srs. Deputados, que nos cabe neste momento talvez mais do que falar, saber ouvir. Existe um sentimento da Nação, e este sentimento da Nação cabe a nós como Parlamentares percebê-lo. O PSDB nasceu, já que estamos fazendo 25 anos, o PSDB no seu nascedouro, Franco Montoro afirmou: "Estamos criando um novo partido, longe das benesses do poder e próximo do pulsar das ruas." Eu penso que é hora de o Parlamento saber escutar este pulsar das ruas, esses movimentos que acontecem não sem uma razão de ser.Meu filho não conheceu o impeachment do Presidente Collor. O meu filho não conheceu efetivamente a ditadura. $\mathrm{O}$ meu filho não participou de movimentos dessa natureza, mas quer participar. Ele quer se posicionar no momento histórico deste País. Ninguém tem o direito de se apoderar deste movimento. Ninguém tem o direito de assenhorar-se deste movimento senão aqueles que dele fazem parte. São esses jovens - aliás, jovens de muitas idades, como dizia um companheiro do PSDB - são eles que estão à frente deste movimento. Não existe lugar para oportunismo num movimento nacional dessa dimensão. Nenhum partido está lá representado. O movimento é de indignação geral contra todos e contra toda a classe política. Façamos uma análise nós mesmos. Façamos uma análise de onde está o erro deste Congresso para gerar indignação. Em vez de apontarmos o erro do Governo Federal, de apontarmos os erros dos Governos Estaduais, façamos uma autocrítica: como é que este Congresso pode ser respeitado por esses jovens se ainda se oculta por detrás e debaixo do voto secreto? Escolhem seus 
representantes - nós aqui estamos -, e, na hora de nos posicionar, voto secreto. Como é que esta sociedade aceita isso? Como é que esta sociedade aceita que, neste Congresso, tramite a Proposta de Emenda à Constituição $n^{\circ} 37$, para tirar poder de investigação do Ministério Público (palmas nas galerias), que é quem evita e impede - evita e impede - que a corrupção ande desenfreada por este País? A luta em defesa da PEC 37 não é uma luta contra o Ministério Público, é uma luta contra a Nação. O Brasil precisa perceber que os mecanismos de investigação e o Ministério Público estão ao lado dessa sociedade.Se nós não soubermos sentir a Nação, se não for para ecoar nesta Casa o pensamento de quem nós representamos, este Congresso valor nenhum tem. Como é que este Congresso pode ter o aplauso da sociedade se apresenta a Proposta de Emenda à Constituição no 33, dizendo que as decisões do Supremo Tribunal Federal têm que se submeter ao Congresso Nacional? Que vergonha é essa, minha gente! O que queremos e aonde queremos chegar? PEC 37, PEC 33, voto secreto... Até outro dia, o $14^{\circ}$ e o $15^{\circ}$ salários eram pagos nesta Casa, vergonhosamente! Enquanto todo cidadão brasileiro trabalha 1 ano para ter o seu $13^{\circ}$, esta Casa desavergonhadamente pagava o $14^{\circ}$ e o $15^{\circ}$ salários. E assim, desavergonhadamente, mantém o voto secreto. É um absurdo que a Nação não compreende e que esse movimento repudia. Reitero aqui: eu poderia vir a esta tribuna para dizer das vaias da Presidente Dilma, para dizer da inflação, para dizer da indignação com o Governo Federal. Eu venho aqui falar de nós mesmos! Tenhamos vergonha na cara para reconhecer o momento histórico em que estamos e que temos para mudar a nossa relação com a sociedade brasileira, para reatar com a sociedade brasileira, para sentirmos esta Nação e trazer sua indignação para dentro desta Casa, dizendo não à PEC 37, dizendo não à PEC 33, dizendo não ao voto secreto.Srs., se continuarmos achando que esses movimentos são contra o Governo do Estado A ou B (palmas nas galerias) ou contra o Governo Federal, nós vamos estar colocando uma venda em nossos olhos e não estaremos a perceber que a indignação é generalizada e estamos todos na vala comum.Não vai ser com mídia que este Congresso vai mudar sua posição; não vai ser com uma bela agência de publicidade que este Congresso vai mudar sua posição perante a sociedade. Nós só mudaremos a visão que têm da gente com postura, postura política, com decisão acertada, e que corresponda aos anseios da Nação. Eu clamo aos colegas Parlamentares: façamos um momento de reflexão para sabermos de nossos próprios erros e, a partir de agora, andemos em consonância com o sentimento da Nação. Muito obrigado, Sr. Presidente. (Palmas.)

O SR. BETO ALBUQUERQUE (PSB-RS. Como Líder. Sem revisão do orador.) - Sr. Presidente, caros colegas, Deputados e Deputadas, todos já fizeram suas reflexões aqui. Eu preciso, em nome do Partido Socialista Brasileiro, também expressar preocupações e convicções com relação ao movimento legítimo que faz com que as ruas, as avenidas das cidades brasileiras comecem a falar, porque, talvez, não estejam sendo ouvidas onde devam ser ouvidas.Na política, de modo geral, sempre houve uma certa tendência à acomodação. Quando se depara com algum movimento reivindicatório, de protestos, há sempre uma tendência do político achar que isso vai passar; que logo ali adiante vira-se a página, entra 
um assunto novo e a sociedade deixará de estar presente.Senhores, não nos enganemos! Este é um movimento que quer ser ouvido. É um movimento que cresce em razão de múltiplas insatisfações. É a voz das ruas que está pedindo para ser ouvida. Lá em Porto Alegre, quando tivemos o primeiro episódio, ali havia um protesto sobre o aumento da passagem de ônibus, a qualidade do transporte, a segurança, a normalidade, a regularidade. Aquele movimento deu voz e guarida a que outros Estados, outras capitais se alinhassem em igual preocupação ou se juntassem àquela preocupação e a outras tantas insatisfações que estão presentes hoje na sociedade brasileira. Insatisfações recorrentes.Nós precisamos admitir, nobres pares, que há certo colapso na representação política deste País. Há uma desconexão da linguagem, da atitude, hoje, da política institucional, com a política que está sendo clamada, reivindicada, exercida nas ruas das cidades brasileiras, ontem aqui em Brasília.Há uma desconexão, há um pacto político lá fora sendo formado, querendo mudanças, querendo o novo. E, na política, talvez não estejamos ainda tratando de um pacto político que dialogue e seja coerente com essas mudanças que estão sendo ouvidas por todos nós, a cada dia com mais gente, a cada dia com mais irresignações, a cada dia com mais protestos. Nós precisamos ouvir esta sociedade, organizada ou não, ela precisa ser ouvida.É por isso que eu quero agradecer à Mesa e ao Colégio de Líderes por termos aprovado a Comissão Geral na próxima quarta-feira, para, nesta tribuna, trazermos o Movimento do Passe Livre, um movimento organizado e que há muitos anos discute este assunto. Para trazermos outras lideranças do movimento, que querem discutir o transporte; para trazermos especialistas, universidades, poderes públicos, para discutirmos com profundidade o assunto transporte.Senhores e senhoras, eles não estão atrás apenas de 20 centavos a menos. É verdade, esta frase está dita, mas eles querem um transporte de qualidade. Eles não querem ser sardinha dentro de ônibus. Eles não querem ser assaltados dentro de ônibus. O povo quer regularidade no transporte. E onde é o espaço para falar? É aqui. Porque, se aqui não falarem, continuarão falando nas ruas, que é o lugar onde nós todos aprendemos, na democracia, a expressar nossas convicções.A Comissão Geral, na quarta-feira que vem, penso, poderá ser uma grande contribuição que daremos a uma das preocupações envoltas nesse protesto Brasil afora. É hora de fazermos a nossa parte, olharmos para as pautas do Governo, sim, mas olharmos muito mais para as pautas do povo, que nem sempre estão presentes neste plenário, nas nossas deliberações.Espero que na quarta-feira estejamos todos aqui, para debater o transporte público.Muito obrigado, Sr. Presidente.

O SR. ANTHONY GAROTINHO (Bloco/PR-RJ. Como Líder. Sem revisão do orador.) Sr. Presidente Paulo Feijó, Deputada Benedita da Silva, Deputado Ricardo Berzoini, Deputado Giovanni Queiroz, ontem eu presenciei, no Rio de Janeiro, e depois acompanhei pelas emissoras de televisão o que se passou no Brasil.E não podemos nos esquivar da nossa responsabilidade. Achar que as milhares de pessoas no Rio, em São Paulo, em Belo Horizonte e em outras capitais foram por causa do aumento das passagens é ingenuidade. As pessoas foram porque, há muito tempo, desejavam falar sobre os dramas que estão para 
ser resolvidos e não o são, muitos por nossa causa.Deputado Paulo Feijó, como V.Exa. sabe, eu tenho um blog investigativo. Coloquei o repórter que trabalha comigo no meio da passeata das 100 mil pessoas, e ele conversou com várias.Uma delas, um senhor, disse assim: "Ah! Eu estou aqui sabe por quê? Porque a minha aposentadoria, quando eu me aposentei, era de oito salários mínimos. Hoje, eu recebo dois". De quem é a culpa? A culpa é nossa. Nós que ainda não votamos esse maldito fator previdenciário.Outro dizia na fila, naquela multidão, que aguarda há 4 meses a marcação de uma consulta pelo plano de saúde. Ele disse: "Estão esperando o quê? Estão esperando que a minha mãe morra, para marcar a consulta do plano de saúde?" E a culpa de quem é? A culpa é nossa, porque até hoje nós não aprovamos leis mais rígidas para os planos de saúde neste País. Outro dizia: "Ah, eu perdi o meu filho! O meu filho tomou um tiro, chegou ao hospital, a um prontosocorro, e não havia médico para ele ser atendido". E por que não há médico? Porque não há financiamento público para a saúde no Brasil. Isso é responsabilidade também nossa. Outro reclamava que o seu filho, desde o início do ano, numa escola pública da Prefeitura do Rio de Janeiro, não tem aula de Química, Física e Matemática. Não tem professores! Não tem professores! A culpa é de quem? A culpa é daquelas pessoas que estavam nas ruas? Não! A culpa é nossa.Outro reclamava que o Prefeito, aliado dos empresários de ônibus, proibiu as vans de circularem no centro da cidade do Rio de Janeiro.Então, havia de tudo. O que nós assistimos ontem foi a uma explosão de cidadania. As pessoas colocaram para fora muitas frustrações que precisavam colocar e desejavam colocar, e não tinham canal para colocar. Lá estavam também, e eu vi - por telefone, conversei, inclusive, com um deles -, policiais militares e bombeiros perguntando: "Cadê a PEC 300, que vocês prometeram, votaram em primeiro turno, aprovaram, e não se fala mais nisso?" A PEC 300 dá um salário digno aos policiais. "Cadê a redução da jornada de trabalho dos profissionais de enfermagem?" Já há praticamente unanimidade nesta Casa, mas o lobby da saúde privada impede que seja votada nesta Casa.Então, eu hoje paro aqui para refletir sobre este momento especial, onde o que está sendo posto à prova no Brasil é a democracia representativa.

Os meios de comunicação também foram bastante castigados ontem, especialmente as organizações Globo.Eu tenho sido duro crítico aqui desta tribuna ao dizer que a Globo manipula o povo, manipula a informação; que a Globo manipulou informações na eleição presidencial Lula-Collor; que a Globo manipulou na abertura política do Brasil; que a Globo manipulou durante a ditadura militar; que a Globo manipulou na bomba do Rio Centro. Ontem o povo dizia: "Fora, Rede Globo". Enxotou os repórteres da Rede Globo. Os repórteres nem tinham nada com isso. Isso não é uma decisão de repórter. Isso é uma decisão de cúpula dessa organização. Mas é hora de nós refletirmos. É hora de nós pararmos. Nós somos homens públicos e vivemos numa democracia representativa. A sociedade parece que quer dar um passo adiante. A sociedade parece que está dizendo que quer ir para a democracia participativa.Dizer que aquelas pessoas são baderneiras, dizer que é uma luta sem causa ou fazer qualquer afirmação conspiratória neste momento seria precipitado por parte de qualquer pessoa. O momento merece reflexão. Reflexão! Os grandes movimentos da história começaram por um pequeno motivo, mas muita coisa represada veio à tona no momento importante.Então, Sr. Presidente, meus colegas Deputados, tudo a que nós assistimos ontem no Brasil inteiro é motivo para que nós pensemos numa ação desta Câmara mais rápida, com medidas concretas em defesa do 
povo, dos mais humildes, de uma educação de qualidade, de uma saúde que preste serviço e não fique contando mortos nas emergências, de uma segurança pública de verdade, e não essa historinha de UPP para inglês ver.O povo, ontem, estava revoltado, porque sabe que o 1,2 bilhão de reais gastos no Maracanã é o dinheiro que está faltando na escola, no hospital, no posto de saúde. $\mathrm{O}$ povo que foi para as ruas sabe que aquele dinheiro todo que foi gasto em obra para turista na Zona Sul do Rio de Janeiro é o dinheiro que falta na Zona Norte, na Zona Oeste, nos bairros mais pobres, nas comunidades mais humildes. Então, eu apelo à serenidade do Governador do Estado, porque ontem a reação foi à base de tiro de fuzil, não foi à base de bala de borracha, não. Temos, hoje, três internados que foram alvejados com tiros de fuzil no Rio de Janeiro. O Governador de São Paulo proibiu até o uso de bala de borracha. No Rio de Janeiro, três pessoas foram alvejadas com tiros de fuzil. Se houve algum excesso, esse excesso não pode ser contabilizado na conta daqueles que precisavam extravasar, precisavam pôr para fora um sentimento que vinha sendo represado.Vejam que a força do povo é tão grande que, no Jornal Nacional de ontem, a Rede Globo praticamente pediu desculpas pela cobertura errônea que vinha dando ao movimento. Há muito tempo não se via a poderosa emissora do "plim-plim", que quer ditar as regras, que quer dizer o que é certo e o que é errado, voltar atrás num editorial, no seu principal jornal, o Jornal Nacional. Pensemos nós, Deputados, antes que seja tarde!Era esse o meu pronunciamento.Muito obrigado, Sr. Presidente.

O SR. PRESIDENTE (Paulo Feijó) - Agradecemos ao Deputado Garotinho o oportuno pronunciamento.

O SR. LUIS CARLOS HEINZE (PP-RS. Pela ordem. Sem revisão do orador.) - Sr. Presidente, colegas Parlamentares, cumprimento esses jovens e essa população que está indo às ruas iniciado pela questão das passagens lá em São Paulo.Mas aquilo não é a causa principal, Deputada Carmen Zanotto. V.Exa., que milita na área da saúde, sabe o caos que é a saúde hoje no nosso País, onde as Prefeituras são obrigadas a aplicar $15 \%$ do seu orçamento e gastam 17\%, 20\%, ou mais; os Estados são obrigados a aplicar $12 \%$ - a maioria não gasta os $12 \%$; e a União, que é o primo rico da história, gasta $5 \%$, $6 \%$ do Orçamento.

Essas questões chegam às ruas, quando vemos aí a inauguração dos estádios, com gastos de 8 bilhões de reais, 10 bilhões de reais. Obras prometidas há 4 anos, 3 anos, não acontecem: um trem-bala; uma refinaria em Pernambuco, orçada em 3 bilhões, 4 bilhões de reais, custando 17 bilhões de reais. Compramos uma refinaria, pela PETROBRAS, nos Estados Unidos, que vale 50 milhões, 100 milhões de dólares, por 1 bilhão de dólares. O povo está enxergando isso: a corrupção que existe hoje, seja no Executivo, seja dentro dos próprios colégios Legislativos. Mas também há os corruptores. Temos que ver os empresários que corrompem os corruptos. Isso é importante. O povo está indo às ruas para mostrar a sua indignação, a sua insatisfação. E é importante que nós possamos nos juntar a essa parcela de bem da sociedade, que tem aqui dentro desta Casa, que tem o Executivo e que tem 
também dentro do empresariado. Isso está chamando a atenção dos políticos que concorrerão a eleições no ano que vem. As falsas promessas, aquilo que se promete e não se cumpre, efetivamente, o povo está indo às ruas para cobrar, quando vai, por exemplo, a um estádio como o Maracanã - 1,5 bilhão de reais foi aplicado naquele estádio. Quanto custaria na China? Quanto custaria em um país desenvolvido como a Alemanha, por exemplo? Seguramente, muito menos do que isso. Agora, 1,5 bilhão de reais? E hoje Odebrecht e Eike Batista vão arrendar por 30 anos. Pagando o quê? Quem pagou foi o dinheiro da sociedade brasileira, quem pagou foi o recurso do Tesouro Nacional. Agora hoje vai ser arrendado, para que duas pessoas, duas empresas possam explorá-lo - quem sabe, por 30 anos -, sem gastar 1 real, 1 centavo naquela obra! Isso o povo está enxergando. Esse tipo de manifestação que é importante. Então, nós temos que somar as vozes da rua com as vozes desta Casa, com as injustiças que se fazem, das promessas que fazem hoje. Eu debatia há pouco, em uma Comissão Especial, a questão indígena. Querem expropriar milhões de hectares de gente que legitimamente está em cima da terra, Sr. Presidente. Portanto, esta é uma das questões que temos que avaliar. Prometem muito em todas as áreas, agora não se consegue executar. Por isso é importante, isso é que o povo neste momento está indo às ruas e cobrando. Parte da população nós levamos às ruas, na última sexta-feira - algo em torno de 50 mil produtores em todo o Brasil -, para protestar contra esses desmandos que estão ocorrendo. Nós vamos nos juntar, vamos nos somar às pessoas de bem, contra a corrupção, contra a sacanagem, contra a safadeza e, principalmente, contra as falsas promessas, porque tem alguém que tem que pagar essa conta. Por isso, Sr. Presidente, o protesto é muito importante. Meus cumprimentos àqueles que, ordeiramente, sem partidarizar a questão, estão indo às ruas para protestar contra essa série de desmandos e falsas promessas que estão ocorrendo no nosso País. Muito obrigado.

O SR. PRESIDENTE (Andre Vargas) - Deputado Luis Carlos Heinze, sem polemizar, quero só avisar que acompanhei as manifestações. Houve manifestação contra a Rede Globo, houve manifestação a favor dos indígenas, há o debate sobre a questão dos direitos humanos. Sem polemizar, quero só levantar que nós precisamos ter muito cuidado em relação a isso. Realmente, o aprofundamento desse debate democrático é importante, como V.Exa. afirma, mas a pauta é bastante ampla, serve para todos. O questionamento às vezes vai até à institucionalidade, de forma geral.

O SR. JOSÉ HUMBERTO (Bloco/PHS-MG. Sem revisão do orador.) - Sr. Presidente, quero cumprimentar os Srs. Deputados e as Sras. Deputadas aqui presentes e a todos que nos assistem neste dia que sucede esses acontecimentos nacionais que chamam a atenção de toda imprensa nacional e do mundo todo, que afinal de contas já com os olhos voltados para o Brasil em função da realização, em nosso solo, da Copa das Confederações pôde assistir à manifestação principalmente dos nossos jovens em relação a sérios problemas que o País vive.Eu acho que cada um de nós tem o dever de, de dentro das oportunidades que cada um temos, nos pronunciar a respeito desses temas. E eu quero aqui fazê-lo, Sr. 
Presidente, para dizer o seguinte: acho que não temos que estar assombrados nem temerosos por essas manifestações. Elas são legítimas. O que talvez a gente não esperasse ou a maioria não esperasse é que a força dessas manifestações talvez tenha assustado a Nação brasileira, e talvez sobretudo a classe política.E eu quero dizer isso porque, de fato, os próprios jovens, sob algumas teses, de repente eram vistos como uma geração meio alienada ou talvez egoísta demais.E eu quero aqui dizer pra vocês que tudo aquilo que aconteceu ontem vem provar exatamente o contrário. Na verdade, o que nós temos pela frente é reformar o Estado e o modelo de Parlamento que nós temos. O que acontece é que esse modelo que aí se encontra não vai ao encontro das aspirações de nossa população. A população não se sente representada e nós aqui temos dificuldade de fazer valer os nossos mandatos.Estou, Sras. e Srs. Deputados, há dois anos e meio no Parlamento. Tenho tido dificuldade de explicar à população que me elegeu tudo aquilo que é nossa atribuição e nossa função. O povo tem razão nas suas cobranças. Afinal de contas, como se sente um trabalhador que tem de viajar 4 horas por dia para se deslocar do seu trabalho até a sua casa, e da sua casa até o seu trabalho, diariamente, ano após ano, e, depois, não concordando com as prioridades que se dá no Orçamento, às vezes tem essa necessidade e quer de alguma forma se manifestar.

Cabe a este Parlamento promover reformas para garantir uma nova forma de representação. Nós vivemos outro tempo, outro mundo, e temos de pensar a respeito. O mundo hoje não é mais analógico, o mundo hoje é digital. Estamos na era das redes sociais, da Internet.E é essa grande revolução que nós temos aqui diante de nós porque uma população manifestando as suas aflições, as suas reivindicações isso é normal; é democrático. O que nós não estamos preparados talvez é para uma revolução sem líderes, aparentemente sem causas. Mas as causas estão postas aí, só não vê quem não quer.Afinal de contas, saúde, investimento na nossa infraestrutura, as questões que faça com que o cidadão tenha, pelo seu próprio mérito, a capacidade de vencer Nós temos que construir esse Brasil e é esse Brasil, é essa nação que o povo espera de nós.Este é o apelo que faço a esta Casa para que reformas como a política, reformas como a tributária, a reforma do Parlamento. não seja postergada, sob o risco de vermos a falência do Estado.Obrigado, Sr. Presidente.

\section{[13]}

O SR. DR. CARLOS ALBERTO (PMN-RJ. Como Representante. Pronuncia o seguinte discurso.) - Sr. Presidente, Sras. e Srs. Deputados, estamos cegos e surdos. Em primeiro mandato como Deputado Federal, desde o início de minha atuação parlamentar, em janeiro de 2011, venho defendendo a tese de que somos meros representantes do povo, de que não "recebemos um cheque em branco" para preenchermos na hora em que bem entendermos e no valor que acharmos conveniente. A minha defesa se estende a outros poderes constituídos de que não podemos agir como se fôssemos os donos da verdade, sem auscultar os reclamos da sociedade brasileira, as suas necessidades básicas, as suas carências, os seus anseios. Nós fomos eleitos para defendê-las, conforme compromisso assumido solenemente quando da posse, quando dizemos: "Prometo manter, defender $e$ 
cumprir a Constituição, observar as leis, promover o bem geral do povo brasileiro e sustentar a união, a integridade e a independência do Brasil".Leio nos jornais, nas revistas e vejo nas tevês que muitos estão surpresos com os movimentos recentes que vêm ocorrendo de segmentos da sociedade, em especial dos jovens, sob o mote de redução dos preços das passagens de ônibus e outros modais.Vi um jovem, em São Paulo, dizer que a necessidade de redução dos preços das passagens foi o estopim para que esses movimentos fossem deflagrados esses movimentos e que retrata parte da insatisfação da sociedade brasileiros com o status quo, aqui e alhures, no mundo. Dizia o cartaz: "Copa FIFA: 33 bilhões; Olimpíadas: 26 bilhões; corrupção: 50 bilhões; salário mínimo: 678 reais; e você ainda acha que é por 20 centavos?"É importante frisar que "somos 200 milhões em ação, pra frente Brasil, salve a Seleção".A que ponto chega o nível de insatisfação do brasileiro, para preterir uma de suas maiores paixões que é o futebol, para tentar incluir na pauta do País a discussão de seus problemas nacionais, que vêm sendo postergados pelo Parlamento nacional, tais como: reforma política; reforma tributária; reforma previdenciária; reforma administrativa; reforma da segurança pública; reforma da saúde; reforma da educação; reforma econômica; reforma orçamentária; reforma do Judiciário; reforma da ética, da moral, dos bons costumes, estas que deveriam embasar o comportamento dos agentes públicos, nos três Poderes e nas três esferas da Federação brasileira, para aplacarmos os desvios de conduta que geram as improbidades administrativas.Li, hoje, na coluna dos leitores de um jornal de grande circulação nacional, um leitor de Niterói dizer: "As manifestações que estão ocorrendo não são apenas por elevação de passagens, mas um sentimento de frustração geral. Nossos representantes, apesar de eleitos, nunca traduzem o sentimento de uma nação. No poder só elaboram, normalmente, leis que os diferenciam do cidadão eleitor e os fazem impunes. Julgam-se nas CPIs e se absolvem, ou se submetem a foros especiais, como cidadãos diferenciados. Criam privilégios financeiros e legais para uso próprio e castas de funcionários especiais para estarem à disposição de seu bem-estar ou interesse público. É a negação do que deveria ser um portador de mandato popular".Tenho visto e ouvido na tribuna da Câmara dos Deputados e do Senado Federal inúmeros Deputados e Senadores que discursam explicitando o mesmo sentimento do leitor de Niterói acima mencionado.Lembro-me de que, numa discussão na Comissão da Reforma Política, em 2012, ao elencarmos os principais pontos que deveriam ser abordados, perguntei: "Mas não vamos ouvir a sociedade?" Ao que fui respondido por um Parlamentar: "Não, senhor. Nós já recebemos a delegação do povo para decidir por ele". Ao que repliquei: "O senhor está enganado. Precisamos ouvir o povo". Tendo o Presidente da Comissão, à época, com um grupo de Parlamentares, ido a várias regiões brasileiras.Lembro-me também de que, quando discutíamos como seriam bancadas as despesas com a Copa do Mundo, alguns defendendo a utilização dos recursos do FGTS, votei contra, dizendo: "Mas não há um entendimento de que essas despesas seriam bancadas pelo empresariado nacional? Não podemos utilizar os recursos do trabalhador brasileiro".

Lembro-me de que quando defendi a extinção dos pagamentos dos $14^{\circ}$ e $15^{\circ}$ salários percebi que alguns não ficaram satisfeitos.Pode parecer a alguns que quero me valer da funesta oportunidade para fazer proselitismo político, ser melhor ou maior do que o rei. A esses peço que acessem o meu blog: http://carlosalbertolopesrj.blogspot.com/. Em 12 de fevereiro escrevi um artigo intitulado Mea-culpa, que está postado no meu blog, 
em que abordo os conflitos entre os três Poderes, o questionamento dos Parlamentares da judicialização pelo Poder Judiciário das ações do Poder Legislativo, a interferência do Executivo no Legislativo, com o excesso de medidas provisórias, a inação do Legislativo na definição e votação de pautas nacionais, tudo sob a perplexidade da sociedade brasileira, que não aguenta mais esse estado de coisas.As manifestações recém-ocorridas, excetuados os desmandos provocados por aqueles que querem se aproveitar politicamente desses momentos, que não concordo, e que não são objeto da maioria, que quer ver e sentir um novo caminho para o nosso País, são justas, democráticas e decorrem do saturamento da sociedade, porque estamos cegos e surdos.Obrigado, Sr. Presidente.

\section{[14]}

O SR. EDUARDO SCIARRA (PSD-PR. Como Líder. Sem revisão do orador.) - Sr. Presidente, Sras. e Srs. Deputados, eu queria inicialmente falar a respeito do ocorrido na semana passada quando da votação do Fundo de Participação dos Municípios.

Um órgão de comunicação, no final da semana passada trouxe uma matéria colocando, inclusive, na boca de Parlamentares do Congresso Nacional manifestações em relação ao motivo que eventualmente teria provocado a queda daquela sessão e a não aprovação do relatório que tratava do Fundo de Participação dos Estados. E foi citado o nome do Deputado Júlio Cesar, Presidente do PSD do Piauí, uma das pessoas mais preparadas do Congresso Nacional nessas matérias, que fez um relatório equilibrado e que, atendendo a um apelo das Lideranças desta Casa, e também do Presidente Henrique Alves e do próprio Governo, no sentido da necessidade de votarmos rapidamente, sem discussão, foi retomado o texto do Senado, e aconteceu o que aconteceu. Na matéria, se falou então que o relatório do Deputado Júlio Cesar teria sido eventualmente a causa de tudo e que, na volta dessa matéria à Casa, seria preciso buscar outro Relator. Eu quero dizer que o PSD não vai admitir essa violência. O Deputado Júlio Cesar, como todos sabem aqui, é uma das pessoas mais qualificadas para a análise dessa matéria, e com toda a certeza vai fazer o relatório quando essa matéria voltar à Casa - e ela deverá voltar na semana que vem -, e nós vamos discutir com toda a tranquilidade, votar e aprovar.Quero agora também me manifestar a respeito disso que tem surpreendido a toda a sociedade brasileira, essa movimentação das ruas que de forma difusa, ou de forma não identificada, essa insatisfação que foi manifesta em todas essas mobilizações pelo Brasil afora, não só em 11 Capitais, mas em mais de 40 Municípios em todo o País. Eu queria dar um testemunho aqui do que presenciei no ano passado no Município de Londrina, Município do Presidente em exercício aqui, o Deputado Andre Vargas, numa eleição que vinha de um processo de muito desgaste da classe política no Município. O Prefeito havia sido cassado; o Vice-Prefeito que assumiu foi preso; três Vereadores foram presos. E no processo eleitoral apresentou-se de última hora o candidato do nosso partido, o PSD, o empresário Alexandre Kireeff, identificado com os movimentos sociais da cidade, movimentos da sociedade organizada. Ele recebeu um bom apoio por parte da população, já que saiu com menos de $1 \%$ nas pesquisas, no início da campanha, e tempo de televisão só recebeu na véspera, no final das convenções, porque o PSD até então 
não tinha candidato, teve só no último dia. E ele foi para a campanha procurando exatamente interpretar isto que a sociedade está manifestando neste momento: uma insatisfação generalizada com relação aos rumos não necessariamente da classe política, mas do Poder constituído; insatisfação, enfim, com o rumo que muitas coisas têm tomado em nosso País.Essa candidatura, na qual não houve nenhuma coligação, uma candidatura que se identificou com a sociedade organizada e que, por meio das redes sociais, ganhou corpo, foi ao segundo turno também, para a surpresa de muitos, e venceu as eleições no segundo turno, para a surpresa de tantos. Mas, com toda a certeza, já antecipadamente dava para se dizer que aquela era uma manifestação silenciosa da população com relação a rumos que não estavam sendo entendidos como corretos pela população.É muito difícil fazer uma análise clara dessa situação. Sobre isso, nós temos de fazer uma reflexão. Essa reflexão, com toda a certeza, não pode ser fruto do calor do momento. É uma reflexão que tem de ser estudada, tem de ser analisada, e, essas ações para responder à sociedade têm de ser praticadas com toda a transparência, porque isso, sem dúvida nenhuma, é o que a sociedade tem nos cobrado.Eu quero deixar aqui esta constatação e dizer que, com toda a certeza, essa mobilização das ruas deve ser entendida como uma manifestação de insatisfação. Para isso, nós que vivemos na vida pública temos de ter responsabilidade com relação ao momento que vivemos. Muito obrigado, Sr. Presidente.

O SR. PRESIDENTE (Andre Vargas) - Obrigado, Deputado Eduardo Sciarra. Lembrei em vários momentos que lá na nossa cidade, assim que a Presidenta Dilma reduziu a alíquota de PIS/COFINS, acho que 2 dias depois o Prefeito Alexandre Kireeff reduziu a tarifa, como numa injeção diretamente na veia. Acho que é assim que se faz mesmo. Quero não somente parabenizá-lo, mas exortar outros a fazerem como ele.

\section{[15]}

O SR. EURICO JÚNIOR (PV-RJ. Sem revisão do orador.) - Muito obrigado, Sr. Deputado. Sr. Presidente, Deputado Paulo Feijó, é uma honra vê-lo aí na Presidência. Assistindo a sua permanência na Presidência me fez lembrar o Dr. Ulysses Guimarães. Durante as manifestações que aconteceram ontem por todo o Brasil, o Dr. Ulysses se aí estivesse, diria que temos de ouvir o clamor das ruas. Eu queria aproveitar para parabenizar a PM aqui de Brasília. Eu saí desta Casa quase à meia-noite, em companhia do Vice-Presidente Andre Vargas, do Deputado Cândido Vaccarezza e do Deputado José Guimarães, Líder do PT e pude acompanhar todo o trabalho que S.Exas. fizeram. Quero parabenizar também os manifestantes que se comportaram de forma tranquila. A PM, ontem, deu uma aula de democracia, junto com os manifestantes. Queria registrar isso, que é muito importante. Pela atitude de S.Exas., parabenizo o Deputado Cândido Vaccarezza, o Deputado José Guimarães e o nosso Vice-Presidente Andre Vargas, que soube conduzir muito bem o movimento ontem. Muito obrigado, Sr. Presidente.

O SR. PRESIDENTE (Paulo Feijó) - O registro de V.Exa. será feito. 
O SR. NILSON LEITÃO (PSDB-MT. Como Líder. Sem revisão do orador.) - Sr. Presidente, Sras. Deputadas, Srs. Deputados, quanto aos discursos que ouvi, principalmente os da base do Governo, eu quero apenas lembrar dois pontos. O Líder do PT falou sobre uma pauta positiva da qual o Brasil precisa. Faz 10 anos que o PT está no poder, e está pensando numa pauta positiva da qual o Brasil precisa? Dez anos não são 10 dias, não são 10 meses. Dez anos é 1 década. E agora estão pensando numa pauta positiva. Deviam ter feito isso antes. Estão querendo fazer laboratório no Governo, aprender a governar todo dia com os erros, penalizando a sociedade brasileira.

Eu também ouvi a Líder do PCdoB dizer que foi a Polícia de São Paulo que assustou a população e que, em decorrência disso, cresceu esse movimento nas ruas. A população não levou susto, tem é impaciência e indignação com a irresponsabilidade do Governo.

Eu ouvi também muitos dizerem que o Congresso é o palco de tudo isso. E é verdade. O Congresso Nacional continua sendo o "puxadinho" do Planalto - a Oposição não admite isso -, continua sendo pautado pelo Planalto. Porém, não é algo aprovado aqui hoje ou amanhã que vai mudar o que está nas ruas. Os movimentos das ruas decorrem da falta de aplicação do orçamento do Governo Federal aprovado no ano passado, resultam da incompetência deste mesmo Governo, que não consegue fazer o dinheiro chegar ao setor de saúde dos Municípios, ao setor de educação dos Municípios, ao setor de infraestrutura.

Quando uma Ministra vem a público dizer que o Brasil não tem projeto para fazer uma obra, eu me lembro daquele coitadinho que, para fazer sua casa, uma meia-água, precisa que o seu projeto seja aprovado pela Prefeitura, precisa do alvará, com a fiscalização do CREA, com a fiscalização de todo o mundo. Se não estiver fazendo a obra de acordo com a legislação, não vai conseguir construir sua casa.

Eu vejo obras sendo embargadas Brasil afora, como aconteceu com aquela boate de Santa Maria. Depois que morreu um monte de gente, começaram a fiscalizar. Essa mesma fiscalização serve para a construção de aeroportos, de portos, de viadutos, de estradas, de hospitais do Governo Federal, que diz que não precisa de projeto.

Esse movimento das ruas não tem proprietário. É absurdo ouvir hoje aqui o Líder do Governo e o Líder do PT, querendo se apossar disso, dizerem: "Olhe, nós concordamos com o movimento". Concordam com o movimento quando ele invade uma loja de carros ou queima um ônibus, mas, quando chega perto do Planalto, colocam 1.800 policiais, para que não se aproxime do Palácio do Planalto ou da casa da Presidente.

Eu acho engraçado quando vejo um movimento como esse, e tive a oportunidade de ouvir vários companheiros falarem, e o que se viu nas ruas foi um movimento de indignação e impaciência. É um movimento difuso e de várias camadas da sociedade? Também é. Só não é contra a própria sociedade. Ele é contra aquele que não aplica direito o dinheiro do povo, que não aplica o recurso público, é contra aquele que não sabe o que está fazendo no poder. 
Realmente, colocaram no mesmo nível toda a classe política. Por quê? Porque a classe política está efetivamente desmoralizada. É verdade. Mas muito mais do que da classe política, a sociedade se cansou do modelo que aí está. Esse modelo se exauriu, acabou. Ele não dá mais certo. Esse modelo não consegue vencer aquilo que precisa ser vencido para melhorar a sociedade brasileira. Sabem por quê? Porque nós somos um dos piores em indústria da América Latina; somos um dos piores em crescimento da América do Sul, só ganhamos do Paraguai; somos um dos piores em educação; somos um dos piores em saúde. Estamos trazendo técnicos de Cuba para substituir médicos no Brasil. O Governo brasileiro não conseguiu achar um rumo, um projeto que efetivamente melhore a vida da população.

Essa angústia da sociedade está sendo traduzida nas ruas agora por crianças, adolescentes, jovens, adultos e idosos. Todos eles estão descontentes, estão muito descontentes, só que não perceberam isto, que tudo ia mal, até não se alcançar o bolso, até a inflação não chegar aonde tinha que chegar.

Infelizmente o Governo, que votou contra a Constituição, faz questão de rasgá-la muitas vezes; o Governo, que votou contra o FUNDEF, faz questão de não promover a educação que deveríamos ter; o Governo, que votou contra o Plano Real, decide, depois de 19 anos, fazer com que ele seja desvalorizado, com que volte a inflação, o grande terror dos brasileiros. Ele destruiu praticamente todos os setores, e agora que mexeu no Plano Real e permitiu aumento da inflação, o grande erro do PT, um erro mortal, mexe com a grande esperança de melhoria de vida.

O SR. PRESIDENTE (Biffi) - Peço a V.Exa. que encerre.

O SR. NILSON LEITÃO - Vou encerrar no mesmo tempo em que o Líder do PT encerrou - 3 minutos depois.

O SR. PRESIDENTE (Biffi) - Claro, com certeza, a Mesa é democrática.

O SR. NILSON LEITÃO - Com certeza, Sr. Presidente, a situação em que vivemos hoje está relacionada a essa inflação que já chegou à cozinha do brasileiro, ao bolso do trabalhador, à cesta básica, ao equipamento que ele deseja comprar, à sua motocicleta, ao valor do aluguel. Está faltando recurso. Agora ele sentiu.

O pior cego é aquele que não quer ver, e o pior surdo é aquele que não quer escutar. O cego que não quer enxergar enxerga bem, mas não quer ver o problema que está ocorrendo. O Governo está fazendo isso. Recebe uma crítica, vê a movimentação da rua, e parece que isso não é com ele. "Não é comigo o problema." Como se não fosse o Executivo que tivesse que executar as obras dos programas. O Governo brasileiro tem que ter autocrítica, humildade e entender que o Brasil chegou a um momento em que não aguenta mais.

A Presidente Dilma Rousseff recebe uma vaia em um estádio brasileiro, e diz que lá só há playboys e classe alta. Ora, não seria mais fácil, com humildade, dizer: "Onde estou errando? Onde preciso recomeçar? Onde o meu povo está sofrendo e em que eu preciso assistir-lhe melhor?"

A voz das ruas, essa voz do povo, que o PT tanto proclamou no passado, precisa ser defendida agora.

Esses movimentos, Presidente Biffi, legitimam a impaciência, a intolerância, a indignação com a classe política que às vezes confunde. 
Eu vi muitos manifestantes dando entrevistas e dizendo o seguinte: "Eu quero saber quanto é o salário do Deputado? O Deputado ganha quanto? O Deputado faz isso, o Deputado faz aquilo". Realmente, acusar o Congresso é mais fácil. Mas é bom o Congresso lembrar algo.

Sr. Presidente, prometo que este é o meu último minuto.

O SR. PRESIDENTE (Biffi) - De novo? Trinta segundos.

O SR. NILSON LEITÃO - Eu sei que não é fácil ouvir todas essas críticas, mas é uma realidade que está acontecendo ali fora dos muros. Eu sei que não é fácil. Mas nós precisamos entender o momento que estamos vivendo. Toda essa sociedade está se organizando.

Eu vou fazer um pedido aqui, pelo que ouvi do Líder do PT: não se apoderem do sofrimento da população ali fora. Muito melhor do que se apoderar disso é tomar atitudes.

O Governo tem condições de tomar atitudes. Libere o Orçamento, execute o Orçamento. Prometeram 6 mil creches, e não liberaram 600. Prometeram milhares de UPAs, e não liberaram 10\% delas. Prometeram 4 bilhões de reais para combater o crack, e não liberaram 390 milhões. Não conseguiram gastar 4\% com as questões agrárias.

Ouçam o povo e façam um governo decente.

O SR. PRESIDENTE (Biffi) - Líder Nilson Leitão, o Presidente Biffi agradece. 